\title{
BRYOPHYTE FLORA OF ALTAI MOUNTAINS. VII. HYPNACEAE AND RELATED PLEUROCARPS WITH BI- OR ECOSTATE LEAVES
}

\author{
МОХООБРАЗНЫЕ АЛТАЯ. VII. НҮРNАСЕАЕ И БЛИЗИЕ СЕМЕЙСТВА \\ БОКОПЛОДНЫХ МХОВ С ЛИСТЬЯМИ БЕЗ ИЛИ С ДВОЙНОЙ ЖИЛКОЙ \\ Michael S. Ignatov ${ }^{1}$, Hisatsugu Ando $^{2} \&$ Elena A. Ignatova $^{3}$ \\ МИХАИЛ С. ИГНАТОВ ${ }^{1}$, ХИСАСТУГУ АНДО $^{2}$ И ЕЛЕНА А. ИГНАТОВА ${ }^{3}$
}

Abstract

\begin{abstract}
The family Hypnaceae in Altai includes the genera Callicladium (1 species), Eurohypnum (1), Gollania (1), Heterophyllium (1), Homomallium (2), Hypnum (11), Podperaea (1), Ptilium (1), Pylaisiella (2), Taxiphyllum (1); family Plagiotheciaceae - Herzogiella (1), Isopterygiopsis (3), Myurella (3), Orthothecium (3), Plagiothecium (4), Platydictya (1); family Entodontaceae - Entodon (3), Platygyrium (1); family Hylocomiaceae Hylocomiastrum (2), Hylocomium (1), Pleurozium (1), Rhytidiadelphus (2); family Sematophyllaceae - Struckia (1). Descriptions and illustrations are given for all species. Homomallium connexum and Hypnum fauriei are reported in South Siberia for the first time. Some evidence for placement of Platygyrium in the Entodontaceae is provided.
\end{abstract}

Abstract

Семейство Нурnaceae на Алтае включает роды Callicladium (1 вид), Eurohypnum (1), Gollania (1), Heterophyllium (1), Homomallium (2), Hypnum (11), Podperaea (1), Ptilium (1), Pylaisiella (2), Taxiphyllum (1); семейство Plagiotheciaceae - Herzogiella (1), Isopterygiopsis (3), Myurella (3), Orthothecium (3), Plagiothecium (4), Platydictya (1); семейство Entodontaceae - Entodon (3), Platygyrium (1); семейство Hylocomiaceae - Hynocomiastrum (2), Hylocomium (1), Pleurozium (1), Rhytidiadelphus (2); семейство Sematophyllaceae - Struckia (1). Для всех видов даны описания и иллюстрации. Homomallium connexum и Hypnum fauriei указываются для Южной Сибири впервые. Приведены аргументы в пользу переведения Platygyrium в семейство Entodontaceae.

This paper continues the series on a descriptive bryophyte flora of Altai Mts. started in the third volume of Arctoa. A brief overview of the environments of Altai and the history of exploration of its moss flora have been published by Ignatov (1994).

In preparing this paper, the authors worked together on identification and description of species. However discussion on generic/familial classification are solely the responsibility of Ignatov, whose ideas sometimes disagree with those of Ando (Ando, 1972, 1973; Nishimura \& al., 1984).

The Hypnaceae are one of the families of mosses poorly delimited from the related fam- ilies, Sematophyllaceae, Plagiotheciaceae, Entodontaceae, and Hylocomiaceae, and its circumscription is treated variously by different authors. Recent publications contribute much to this topic, resulting in suggestions of changing of familial position for many genera. However some of these new ideas are still in dispute, so it seems better to describe species of these families in one paper.

The following genera are included in this paper:

Hypnaceae: Callicladium, Eurohypnum, Gollania, Heterophyllium, Homomallium, Hypnum, Podperaea, Ptilium,Pylaisiella,Taxiphyllum; Plagiotheciaceae: Herzogiella, Isopterygiop-

\footnotetext{
1 - Main Botanical Garden of Russian Academy of Sciences, Botanicheskaya 4, Moscow 127276 Russia - Россия 127276 Москва, Ботаническая 4, Главный ботанический сад РАН

2 - Department of Biological Science, Faculty of Science, Hiroshima University, Kagami-yama, Higashi-hiroshima, Hiroshim-ken 739, Japan

3 - Department of Geobotany, Biological Faculty, Moscow State University, Moscow 119899 Russia - Россия 119899, Москва, Московский университет, Биологический факультет, каф. геоботаники
} 
sis, Myurella, Orthothecium, Plagiothecium, Platydictya;

Entodontaceae: Entodon, Platygyrium;

Hylocomiaceae: Hylocomiastrum, Hylocomium, Pleurozium, Rhytidiadelphus;

Sematophyllaceae: Struckia.

Definition of the Amblystegiaceae also poses some problems around Calliergonella, Campylium, Campyliadelphus, Campylophyllum, and Pseudohygrohypnum. These genera will be discussed in the paper on Amblystegiaceae. However some of them are included in the key of the genera (marked by an asterisk rather than page).

The terminology used in the paper is mostly standard. However some explanations are necessary.

(1) Pseudoparaphyllia. Though this organ was specially discussed by some authors, the difference between pseudoparaphyllia in a strict sense and juvenille branch leaves remains disputable. Enroth (1994) suggested considering pseudoparaphyllia as foliose organs, usually lanceolate, situated obviously apart from branch initial and not confused with broadly ovatetriangular juvenile branch leaves. According to this conception pseudoparaphyllia occur in relatively few species, while most of the species have no pseudoparaphyllia. Hedenäs (1995) used the term pseudoparaphyllia for both lanceolate structures around and broad structures at the base of juvenile branches. He considered pseudoparaphyllia absence a rare phenomenon when after branch removal nothing leaf-like remains on stem (as in Plagiotheciaceae). We use here the latter teminology. One problematic case in pseudoparaphyllia interpretation is discussed under Orthothecium.

(2) Rhizoid position. In most pleurocarps, rhizoids are clustered on the stem just below the leaf insertion. In the zone of close contact with the substrate, rhizoids are usually more numerous and in part may arise from the abaxial side of leaves. However, in places where few rhizoids are present their position is clearly cauline, and typically they form a transverse row or a transversely ovoid group. In some genera under question rhizoids are axillary. This means their position is in leaf axils, usually 1-2 cells above the leaf. Axillary rhizoids are usually fewer, purplish, finely granu- lose and form a longitudinal row or otherwise longitudinally ovoid group (if rhizoids are two, they are nearly always one above another). Some deviation from this type is seen in Herzogiella where rhizoids are shifted more distally from the leaf below them and grouped mostly near the corner of the leaf situated above; however this type is considered primarily axillary due to rhizoid texture, often longitudinally seriate positioning and also sometimes a more clearly axillary pattern. The similar position of axillary rhizoids is observed at branch tips of Hylocomiaceae, Entodon, Ptilium. In Plagiothecium rhizoids are confined to the abaxial side of leaf, mostly along the costa, and this pattern was seen also in branches of some specimens of Entodon. In proximal branches of Plagiothecium rhizoids are numerous and sometimes partly cauline, but the places with dense rhizoids seem too abnormal to take them into consideration. Rhizoid position of Struckia is discussed under that genus. Rhizoids on branches often have a different position than those on stems and also are variable even within a single species (e. g., Entodon concinnus).

(3) Leaf length of falcate leaves indicate the approximate length if they were straight; although there is no precise procedure of measurements in this case, we think that without such an approximation, the description of species looks incomplete.

(4) Laminal cell width is measured as the width of lumen + cell wall, with an indication in brackets of widths of the two, respectively.

(5) Capsule length is measured in dry inoperculate herbarium material.

(6) Annulus is described according Buck (1980), only for a structure with separating cells. The situation when a deciduous annulus is not seen at the urn mouth is described as annulus none, though in fact thick-walled hygroscopic cells remain attached to the operculum or to the urn.

(7) The terms lamella and trabecula were both applied to the projecting walls on either surface of the exostome tooth. We will name them dorsal and ventral trabeculae. Papillae on the dorsal trabeculae are usually very similar to those on dorsal vertical projections, so the description of papillae on the dorsal trabeculae implies 
also papillae on the dorsal vertical projections. Ventral trabeculae in the proximal part of tooth are smooth (non-papillose) always, above the transition zone are papillose or smooth, and in the uppermost part of tooth are smooth again in many species which have papillose ventral trabecule in the middle. In description smooth or papillose ventral trabeculae mean the state of this character at about $3 / 4-4 / 5$ of tooth length.

(8) On SEM micrographs the margin of the exostome tooth in its distal portion is often differentiated, becoming more thick. We call this margin incrassate (figs. on pp. 104, 110, etc.) or non-incrassate (figs. on pp. 47, 49, etc.).

SEM observations were made with Hitachi S-405A SEM at $15 \mathrm{kV}$. For these observations were taken dry capsules from herbarium, mostly from Altaian collection. Peristomes were coated by gold without additional preparation.

\section{KEY TO THE ALTAIAN GENERA OF HYPNACEAE AND RELATED PLEUROCARPS WITH BI- OR ECOSTATE LEAVES:}

1. Paraphyllia numerous, branched, densely covering the stem; robust mosses . . . . . . . . . 2

1. Paraphyllia absent or rarely simple, lanceolate, not conspicuous . . . . . . . . . 3

2. Costa double and short; stem regularly bi pinnate-branched; plants each year forming flat fronds resulting in stepwise appearance ......... Hylocomium (p. 104)

2. Costa single or double, to mid-leaf or longer; plants less regularly 1-2(3)-pinnatebranched, without stepwise appearance ............. Hylocomiastrum (p. 99)

3. Leaves broadly obtuse; robust mosses with stems ascending to erect . . . . . . 4

3 . Leaves acute to acuminate, usually \pm prostrate ................... 6

4. Stem deep-red... Pleurozium (p. 107)

4. Stem green to yellow-brown .. 5

5. Alar cells large, inflated, forming a well-delimited group .. Calliergonella cuspidata*

5. Alar cells \pm small .. Entodon concinnus (p. 25)

6. Leaves strongly reflexed (or sometimes spreading at right angle from the base) $\ldots 7$

6. Leaves not reflexed . . . . . . . . . 10

7. Plants robust $\ldots \ldots \ldots \ldots \ldots \ldots \ldots . . \ldots$

7. Plants rather small ........... 9
8. Leaves serrate, auriculate; largest cells at base in the middle between the costa and margin; costa double, prominent, to $1 / 3$ $2 / 3$ of the leaf length ......... Rhytidiadelphus (p. 105)

8. Leaves \pm entire, not auriculate; largest cells at base in leaf corners; costa double, usually short (rarely longer, up to $1 / 3$ the leaf length)

... Campylium p. p. (Campyliadelphus)*

9. Teeth in lower leaf margins formed by two cells: upper end of the lower cell and lower end of the upper cell; laminal cells distinctly prorate ........... Podperaea (p. 60)

9. Teeth along the whole leaf margin formed by one cell; laminal cells smooth

....... Campylium (Campylium s. str. \&

Campylophyllum)*

10.Leaves decurrent; rhizoids abaxial near leaf bases; plants medium-sized to small, rarely branched, \pm complanately foliate ............. Plagiothecium (p. 46)

10.Leaves non-decurrent; rhizoid position otherwise ................ 11

11. Rhizoids on the stem clearly axillary, 1-2 cells above the leaf axil (rarely higher above the axil in Herzogiella), usually purple and finely granulose ................ 12

11. Rhizoids on the stem non-axillary, appearing mostly below the leaf base (but sometimes \pm axillary at branch tips), usually brown and smooth . . . . . . . . . . 16

12.Plants small, imbricate, very fragile; leaves strongly concave, short, usually with length to width ratio less than $2: 1$; laminal cells prorate or papillose on the abaxial surface ............................... 40)

12. Plants otherwise .............. 13

13. Plants small to robust, \pm orthotropic, often tinged with bronze or red; leaves straight, acuminate; on moist rock outcrops or on soil in tundra ......... Orthothecium (p. 42)

13. Plants prostrate, green to yellow green . . 14

14.Plants medium-sized; leaves falcate, rather loosely arranged, sharply serrate above, serrulate downward to the base; capsules slightly curved; rhizoids mostly situated between leaves; epixylic autoicous plant usually with sporophytes

.............Herzogiella (p. 53) 
14.Plants otherwise; leaves less serrate, smaller .......................... 15

15. Plants small to medium-sized, usually pure green; epidermal cells larger or as large as cells of the subtending layer; laminal cells linear to short, 1:4-7 (I. alpicola); stem with central strand ... Isopterygiopsis (p. 35)

15. Very small thin green plants with loosely arranged leaves; laminal cells short, 1:3-4; stem without central strand

.................. Platydictya (p. 39)

16. Leaves near shoot tips caducous, resulting in a subterminal naked zone on many shoots; leaves laxly areolate .................... Struckia (p. 97)

16. Plants without leafless zones near shoot

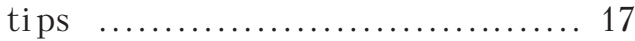

17. Capsules perfectly straight; leaves symmetric or nearly so . . . . . . . . . . . 18

17. Capsules curved or / and somewhat inclined, or plants without sporophytes; leaves falcate-secund to \pm symmetric . . . . . . . 20

18. Leaves \pm shortly acute; plants distinctly complanate ............Entodon (p. 25)

18. Leaves acuminate; plants \pm julaceous . . 19

19. Plants dark, with brood branches clustered in leaf axils, especially near branch ends; leaf margins recurved ..... Platygyrium (p. 33)

19. Plants \pm shiny, without brood branches; leaf margins erect ........ Pylaisiella (p. 56)

20.Plants rather tall, erect, densely and regularly plumose-branched; leaves strongly falcate to circinate, plicate

....................... Ptilium (p. 91)

20.Plants more or less prostrate; leaves not or scarcely plicate . . . . . . . . . . 21

21. Plants complanate; leaves straight, acute to shortly acuminate, serrulate; alar cells indistinctly differentiated .. Taxiphyllum (p.94)

21. Leaves longly, rarely shortly acuminate; straight to falcate; alar cells \pm differentiated ............................. 22

22. Leaves strongly curved (tip is turned from $90^{\circ}$ to $180^{\circ}$ ) .. Hypnum p.p. (p. 68)

22. Leaves symmetric or curved less than on $90^{\circ} \ldots \ldots \ldots \ldots \ldots \ldots \ldots \ldots \ldots \ldots$

23. Epidermal cells of stem enlarged, thinwalled ....................... 24
23. Epidermal cells of stem small, thick-walled

24.Alar cells thin-walled, inflated .......... Calliergonella lindbergii *

24. Alar cells not inflated, \pm opaque Hypnum p.p. (p. 68)

25.Autoicous, usually bearing sporophytes

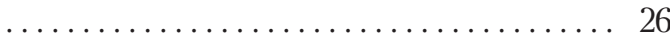

25. Dioicous, usually without sporophytes . . 28

26. Small plants, with \pm straight leaves; usually on rocks ..... Homomallium (p. 63)

26. Large plants, usually on rotten wood (rarely on trunks or rocks) . . . . . . . . 27

27. Plants golden-yellow; alar cells thick-walled and brownish .... Heterophyllium (p. 90)

27. Plants green; alar cells thin-walled, hyalinetransparent ........ Callicladium (p. 86)

28. Leaves serrate in acumen, \pm plicate; large plants ............... Gollania (p. 92)

28. Leaves entire or with serrulate acumen . . 29

29. Leaves straight, concave, imbricate, distinctly serrulate in upper part; alar regions extending $1 / 3$ the leaf length

.................. Eurohypnum (p. 67)

29 . Leaves \pm falcate; alar cells not so numerous

................. Hypmum p.p. (p. 68)

Entodontaceae Kindb.

The family was revised by Buck (1980), who delimited it using mostly sporophytic characters, namely the reduction of endostome (basal membrane low or lacking) and exostome (lack of trabeculae on the inner surface of teeth). Most species are autoicous (rarely dioicous), and have terete or complanate foliage, straight capsules, a tendency in ornamentation of the outer exostome to form solid cristae, transverse below and often oblique to longitudinal above.

Buck (1980) noted a peculiar ornamentation of the exostome in Platygyrium, though he did not discuss it in detail. Ornamentation of the outer exostome of Platygyrium is reticulate, but distinct from the reticulate pattern of the Hylocomiaceae. In the latter it is a result of fusing of transversal cristae, while in Platygyrium the main orientation of cristae is longitudinal. Under the light microscope exostome teeth of Platygyrium above the middle look papillose, rather similar to those of most Hypnaceous mosses. However the dots ("papillae") comprise 
an optical effect from centers of reticulum loops, obvious from SEM micrographs (Figs. 000).

Buck (1980) retained Platygyrium in Hypnaceae, arguing this by the presence of normally developed ventral trabeculae of the exostome teeth. However high trabeculae on the inner surface of teeth are known in some species of Entodon (E. brevisetus (Hook. et Wilson) Jaeg., E. scabridens Lindb., etc., cf. Mizushima, 1960)). In most Entodon species they are absent in the distal half of teeth but \pm well-developed below. Therefore a similarity in peristome structure between Platygyrium repens and Entodon is more striking than with that of any genus of Hypnaceae, and therefore Platygyrium is worth considering as a member of the Entodontaceae.

Additional similarities of Entodon and Platygyrium include (1) erect capsule; (2) low conic operculum with long beak; (3) epiphytic and epixylic habitat preferences and rather southern, hemiboreal to temperate distribution (though some species of Hypnaceae also have such ecology and distribution).

The gametophytic characters of Platygyrium do not disagree with the Entodontaceae (mostly because there are almost no valuable differences in gametophytes of Hypnaceae and Entodontaceae). The dioicous condition is unusual in Entodontaceae, but some Entodon species are dioicous, and the character of sexual condition is not stable in most families of pleurocarps.

Entodon C. Müll.

The genus includes about 100 species with predominantly tropical to temperate distribution. Only one species, Entodon concinnus, penetrates the Arctic regions and high mountains of the Northern Hemisphere. Several other species, like Entodon cladorrhizans, E. schleicheri and E. compressus, are principally temperate, but also occur in the hemiboreal zone.

KEY TO THE ALTAIAN SPECIES OF ENTODON

1. Yellowish plants with ascending stems, dioicous; typically epigeic, rarely epilithic or epiphytic; branches julaceous; leaves with broadly rounded apex and non-transparent 2-3-stratose alar parts ....... E. concinnus (p. 25)

1. Pure green plants with totally plagiotropic stems, autoicous; typically epi phytic,occasionally epilithic; stem and branches distinctly complanate; leaves acute to acumi- nate at apex, with transparent unistratose alar parts ....................... 2

2. Robust plants with shoots about $2 \mathrm{~mm}$ broad at the tip; branches straight; seta yellowish; capsule cylindric; exostome teeth striolate below, papillose in the middle, weakly papillose to smooth above ................ E. schleicheri (p. 28)

2. Medium-sized plants with shoots about $1 \mathrm{~mm}$ broad at thetip; branches distinctly curved; seta reddish; capsule ovoid; exostome teeth papillose below ................ E. compressus (p. 27)

Entodon concinnus (De Not.) Par., Index Bryol., ed. 2, 2: 130. 1904. - Hypnum concinnum De Not., Mem. Reale Accad. Sci. Torino 39: 220. 1836. - Entodon orthocarpus (Brid.) Lindb., Musci Scand. 39. $1879 . \quad$ Fig. 1

Plants green to yellow-green, in loose mats. Stem ascending to erect, to $10 \mathrm{~cm}$ long, with well-developed central strand, regularly pinnate-branching; branches 10-13 mm long; branching often sympodi$\mathrm{al}$, and in suboptimal conditions to 6 sympodial steps. Pseudoparaphyllia broadly triangular. Axillary hairs 4-celled, $100 \mu \mathrm{m}$ long, apical cell 38-50×10 $\mu \mathrm{m}$; rhizoids rare, on stem below leaf insertions, axillary on branch tips or (on other plants) abaxial on leaves. Stem leaves 1.9-2.6 $\times 1.0-1.3 \mathrm{~mm}$, ovate, widest at $1 / 3$ of leaf length, obtuse. Branch leaves 1.4-1.6 $\times$ $0.7-0.8$, widest at $1 / 2-2 / 3$ of leaf length. Laminal cells 75-115 × 5-6 (3-4.5/1.5-2.0) $\mu \mathrm{m}$; alar cells numerous, subquadrate, ca. $7 \times 7 \mu \mathrm{m}$, thick-walled, forming multi-stratose inflated areas.

Dioicous. Sporophytes found in Altai only in Bele (mean annual temperature ca. $+4^{\circ} \mathrm{C}$, preci pitation 400 $\mathrm{mm}$, rather open Larix + Betula forests), but represented only by old capsules with imperfectly preserved peristomes. Outer perichaetial leaves \pm obtuse, squarrose. Inner perichaetial leaves $3.5 \mathrm{~mm}$ long, ecostate. Seta $1.5 \mathrm{~cm}$. Capsule ca. $2.0 \mathrm{~mm}$ long. Exostome teeth $0.35 \mathrm{~mm}$ long, densely papillose below, \pm smooth above. Endostome segments of the same length, \pm smooth. Spores 18-21 $\mu \mathrm{m}$.

The orthotropic julaceous habit is similar to that of Pleurozium schreberi, but the latter species differs at once by the red stem (easily seen even through leaves).

Distribution: Entodon concinnus is widely distributed in the Holarctic, penetrating rather far to the north in oceanic regions, including Iceland, Norway and Sweden in Europe, Chukotka Peninsula, Arctic Alaska, and Newfoundland. It is absent in boreal lowlands, but common in mountains of both 

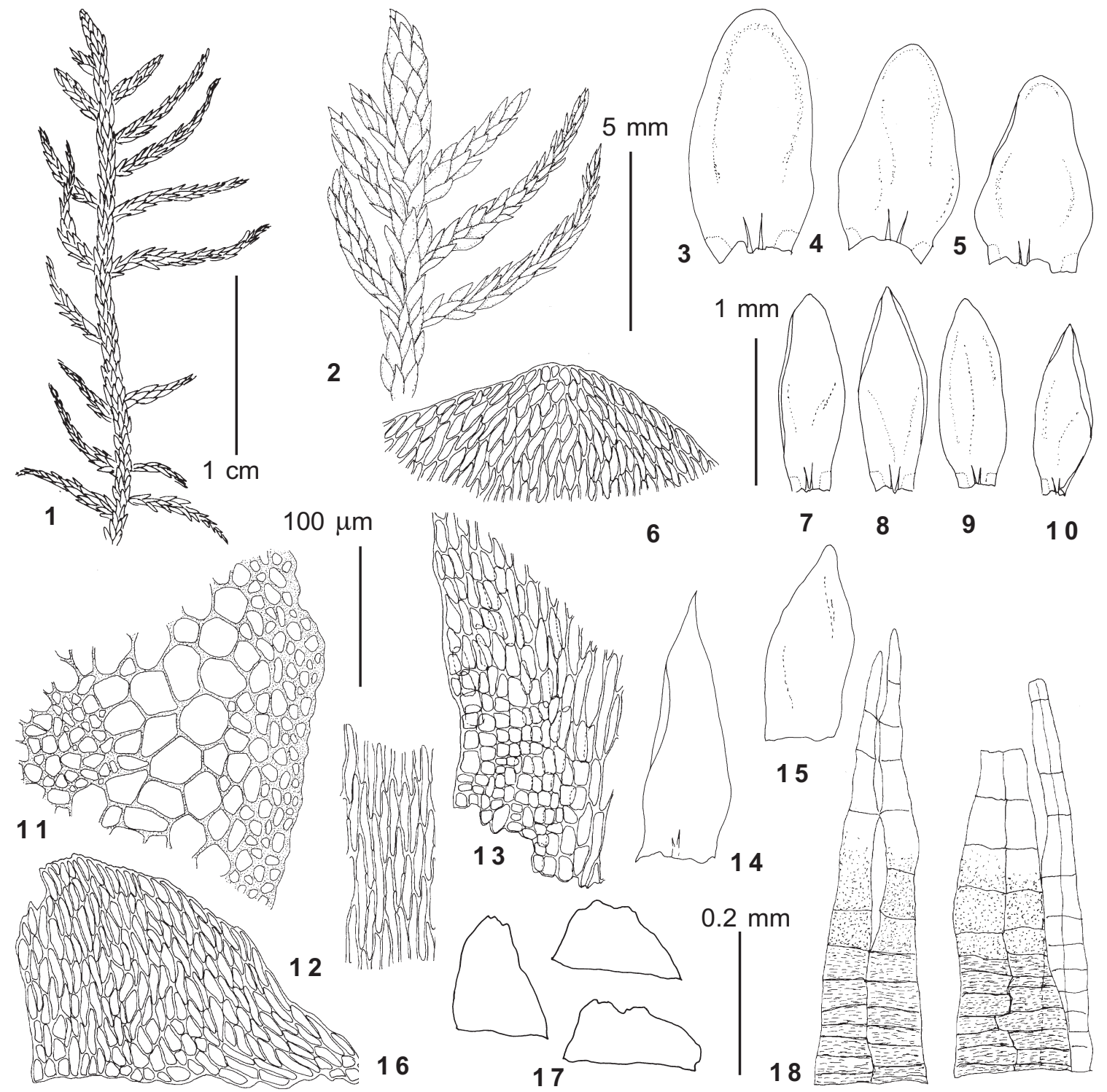

Fig. 1. Entodon concinnus (De Not.) Par. (1-13, 16-17 - from Yailyu $500 \mathrm{~m}$ Ignatov 0/996; 14-15, 18 - from Bele 500 m Ignatov 0 /66): 1-2 - habit; 3-5 - stem leaves; 6 - upper laminal cells of stem leaf; 7-10 - branch leaves; 11 - stem cross-section; 12 - middle laminal cells of stem leaf; 13 - alar cells of stem leaf; 14-15 - perichaetial leaves; 16-17 - pseudoparaphyllia; 18 - part of peristome. Scale bars: $1 \mathrm{~cm}$ - for $1 ; 5 \mathrm{~mm}$ - for $2 ; 1 \mathrm{~mm}-$ for 3-10, 14-15; $0,2 \mathrm{~mm}$ - for $17 ; 100 \mu \mathrm{m}$ - for $6,11-13,16,18$.

Eurasia (Alpes, Carpatians, Caucasus, Pamir, Tian-Shan, moss species), xerophytic shrubby steppes and formAltai, Sayan, mountains of Mongolia, Russian Far East, ing extensive carpets in Larix stands. In the most China, Japan) and North America. Outside the Hol- xeric south-eastern part of Altai, on Kuraiskij Range arctic it is known in New Guinea and Ecuador. In E. concinnus penetrates mountain tundra, reaching the northern part of Altai E. concinnus has a rather $2750 \mathrm{~m}$, growing there on sheltered rock outcrops or scattered distribution on rocks and sometimes on on soil bank along temporary stream beds.

fallen trunks, and rarely on living inclined trees in

Specimens examined: Aedigan Creek, $5 \mathrm{~km}$ upstream the forest zone (not exceeding $1400 \mathrm{~m}$ ). In drier areas $600 \mathrm{~m}(34 / 44) ;$ Bele $500 \mathrm{~m}(0 / 66 ; 0 / 995 ; 0 / 997), 550 \mathrm{~m}$ with forest-steppe vegetation E. concinnus becomes (0/71); Bolshoi Yaloman Creek, in middle course $1500 \mathrm{~m}$ more common, occurring in wider range of habitats: (Makarov 15.VII.1972); Chemal, $4 \mathrm{~km}$ upstream along over-grazed pastures (where it sometimes is the only Katun $450 \mathrm{~m}(34 / 110)$; Chiri Creek, 0.5 km upstream 450 


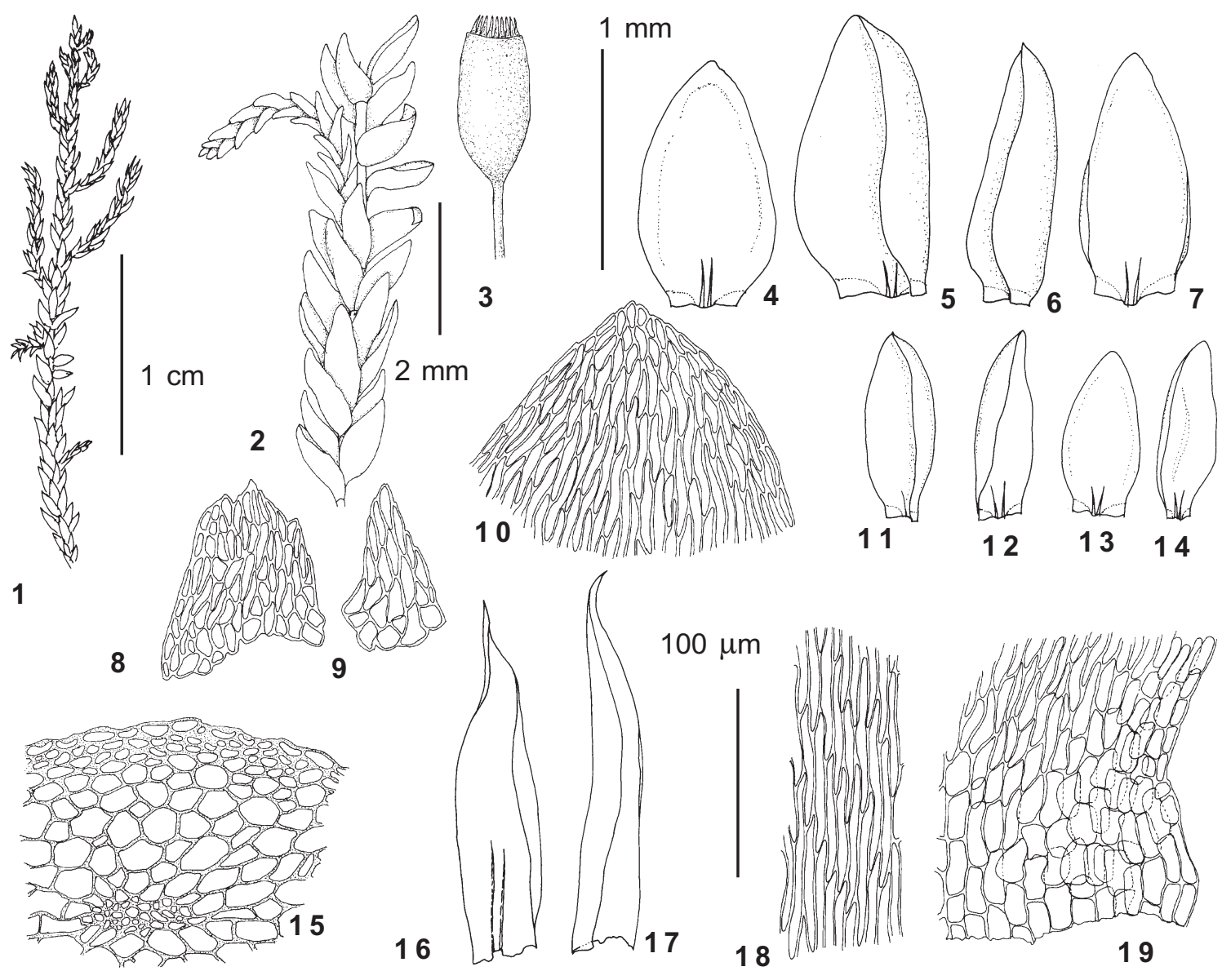

Fig. 2. Entodon compressus C. Müll. (from Maima 280 m Ignatov 35/60): 1-2 - habit; 3 - capsule; 4-7 - stem leaves; 8-9 - pseudoparaphyllia; 10 - upper laminal cells of stem leaf; 11-14 - branch leaves; 15 - stem crosssection; 16-17 - perichaetial leaves; 18 - middle laminal cells of stem leaf; 19 - alar cells of stem leaf. Scale bars: 1 $\mathrm{cm}$ - for $1 ; 2 \mathrm{~mm}$ - for $2-3 ; 1 \mathrm{~mm}$ - for $4-7,11-14,16-17 ; 100 \mu \mathrm{m}$ - for $8-10,15,18-19$.

$\mathrm{m}(17 / 18)$; Elekmonar Creek, 5 km upstream $700 \mathrm{~m}$ (26/ 101); Karagai $440 \mathrm{~m}$ (0/278), $450 \mathrm{~m}$ (Zolotukhin 11.VIII.1988); Kayakkatuyarykskij Creek $1600 \mathrm{~m}$ (8/ 72), $1630 \mathrm{~m}$ (8/127); Kishte $440 \mathrm{~m}$ (Zolotukhin 11.VII.1988); Kokkul Lake 2300 m (33/10); Kokorya Creek $2400 \mathrm{~m}(32 / 16)$; Kuba Creek, at mouth $500 \mathrm{~m}$ (Makarov 3.VI.1972); Malyi Yaloman Creek, 4 km upstream $900 \mathrm{~m}$ (25/45); Tabozhok Peak $2250 \mathrm{~m}$ (31/151), $2750 \mathrm{~m}(31 / 75)$; Ulagan $1220 \mathrm{~m}(36 / 206)$; Ust-Sema $350 \mathrm{~m}(24 / 10), 400 \mathrm{~m}(24 / 129) ;$ Yailyu $440 \mathrm{~m}$ (0/639), $450 \mathrm{~m}(1 / 52), 500 \mathrm{~m}(0 / 996)$.

Entodon compressus C. Müll., Linnaea 18: 707. 1845. - E. challengeri (Par.) Card., Beih. Bot. Centralbl. 17: 32. 1904. Figs. $2 \& 3$

Plants medium-sized, glossy, green. Stem prostrate, complanately foliate, $3 \mathrm{~cm}$ long; central strand welldeveloped; branches to $8 \mathrm{~mm}$ long, curved. Pseudoparaphyllia broadly triangular. Axillary hairs 4-celled, $110 \mu \mathrm{m}$ long, apical cell $45 \times 4.5 \mu \mathrm{m}$. Stem leaves $1.1-1.3 \times 0.6-0.8 \mathrm{~mm}$, ovate, obtuse to shortly acute; margins entire or minutely serrulate near the apex. Branch leaves 0.7-0.9 × 0.3-0.4 mm. Laminal cells $55-75 \times 6(5 / 1) \mu \mathrm{m}$. Alar cells shorter in wide area extending to the costa.

Autoicous. Sporophytes frequent. Inner perichaetial leaves greatly enlarged. Seta $0.5-0.7 \mathrm{~cm}$. Capsule ca. $2.0 \mathrm{~mm}$ long, ovoid, rugose. Operculum conic, with long beak. Annulus of 2 rows of large cells, deciduous. Exostome teeth straight when dry, gradually tapered, entire, densely low-papillose on both surfaces; ventral trabeculae low. Endostome segments with indistinct papillae. Spores $13 \mu \mathrm{m}$.

Distribution: This species comprises in general an example of the classic East Asian - eastern North American disjunction. In Asia it is widespread throughout most of Japan (absent in Ryukyu) and China (absent in Taiwan and Hunan), Korea, Mongolia, southern part of Russian Far East and South Siberia westwards to Altai. Further to the west it was collected once in Vologda Province in Cenrtal Russia (LE!, H!) and was reported also from Caucasus (Düll, 1985). In Altai Entodon compressus is 

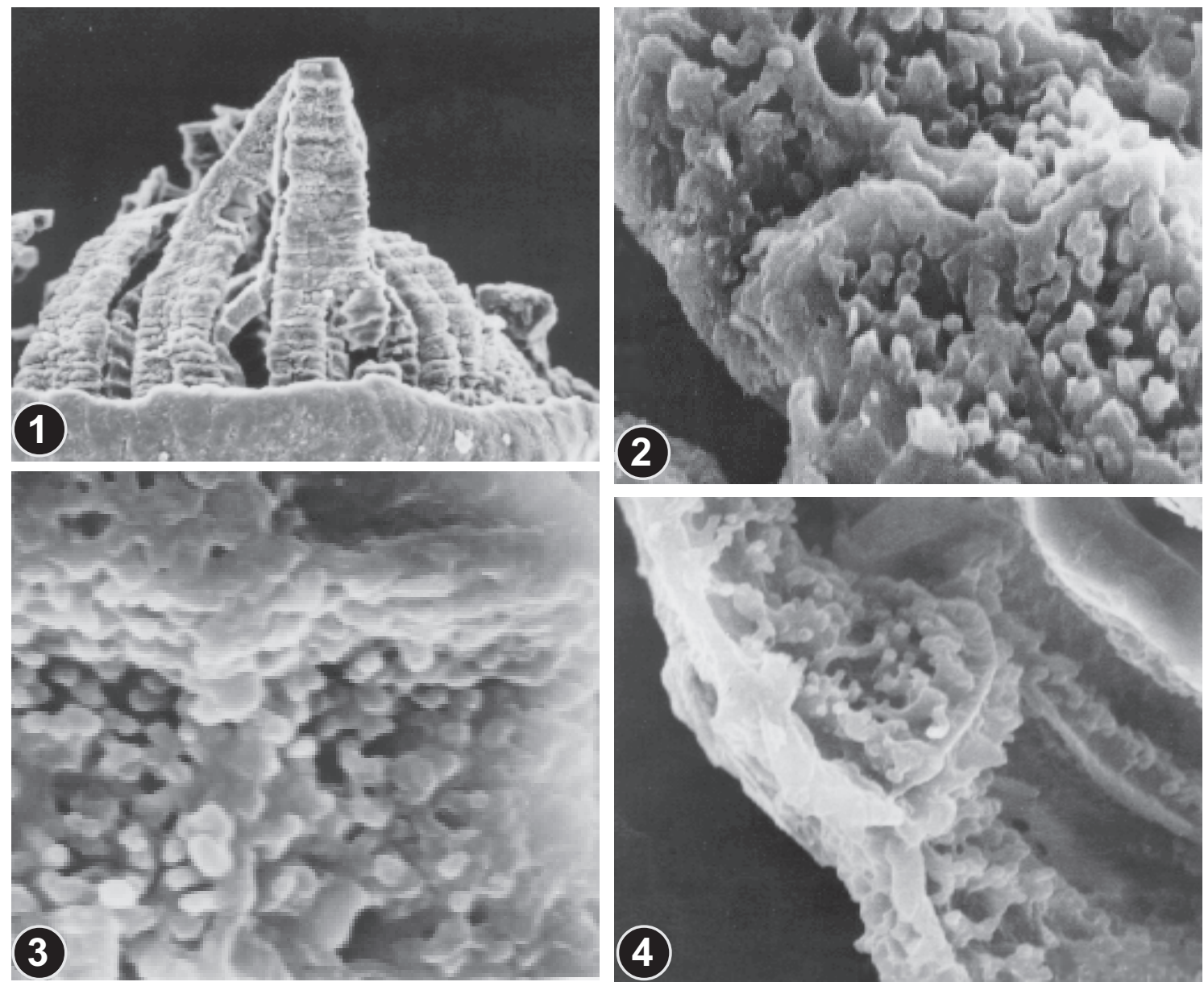

Fig. 3. Entodon compressus C. Müll. (from Maima $280 \mathrm{~m}$ Ignatov 35/43): 1 - perisome (450×); 2 - outer surface of tooth near the base $(5000 \times)$; 3 - outer surface of tooth in upper third $(6500 \times)$; 4 - side view of tooth above the middle, showing papillose inner surface and low ventral trabeculae $(4600 \times)$.

strictly confined to flood valleys of large rivers where Populus stands are developed. It grows mostly on Populus trunks, or rarely on nearby rocks.

Specimens examined: Chulyshman River, at Bashkaus mouth 470 m (Zolotukhin 23.IX.1989); Gorno-Altaisk 400 m (35/32); Kyrsai 450 m (Bardunov 6.VII.1966 IRK!; Schischkin 7.IX.1931 LE!); Maima $280 \mathrm{~m}(35 / 18 ; 35$ $21 ; 35 / 22 ; 35 / 43 ; 35 / 44 ; 35 / 59 ; 35 / 60)$.

Entodon schleicheri (Schimp.) Demeter, Rev. Bryol. 12: 87. 1885. - Isothecium schleicheri Schimp. in Spruce, Musci Pyren. 71. 1847.

Figs. $4,5 \& 6$

Plants robust, glossy and green. Stem prostrate, complanately foliated, $8 \mathrm{~cm}$ long; central strand present; branches to $8 \mathrm{~mm}$ long, straight. Pseudoparaphyllia broadly triangular. Axillary hairs 4-celled, $180 \mu \mathrm{m}$ long, apical cell $80 \times 8 \mu \mathrm{m}$. Stem leaves 2.0 $2.5 \times 0.8-1.1 \mathrm{~mm}$, ovate, oblong-ovate, acute, narrowed to the base; margins entire or minutely serrulate near the apex. Branch leaves ca. $1.4 \times 0.5 \mathrm{~mm}$. Laminal cells 100-120 × $6(4 / 2) \mu \mathrm{m}$. Alar cells subquadrate, forming a well-delimited triangular group, about 1015 along the margin.

Autoicous. Sporophytes frequent. Inner perichaetial leaves greatly enlarged. Seta $1.3 \mathrm{~cm}$. Capsule ca. $2.5 \mathrm{~mm}$ long, long-cylindric. Annulus none or of 1 row on round cells with $40 \mu \mathrm{m}$ in diameter. Operculum conic, with long beak. Exostome teeth straight when dry, $0.35 \mathrm{~mm}$ long, gradually tapered, entire, striolate below, densely papillose in the middle, smooth above; ventral surface smooth. Endostome ca. $0.3 \mathrm{~mm}$ long, segments smooth. Spores $13 \mu \mathrm{m}$.

In Altai this species is easy to recognize by its large shiny complanate plants, usually with numerous capsules. Several collections from (1) strongly shaded and (2) very dry willow stands in steppe areas were much thinner; without sporophytes these specimens can be confused with E. compressus, but the latter differs in the smaller size of plants and arcuate branches. 


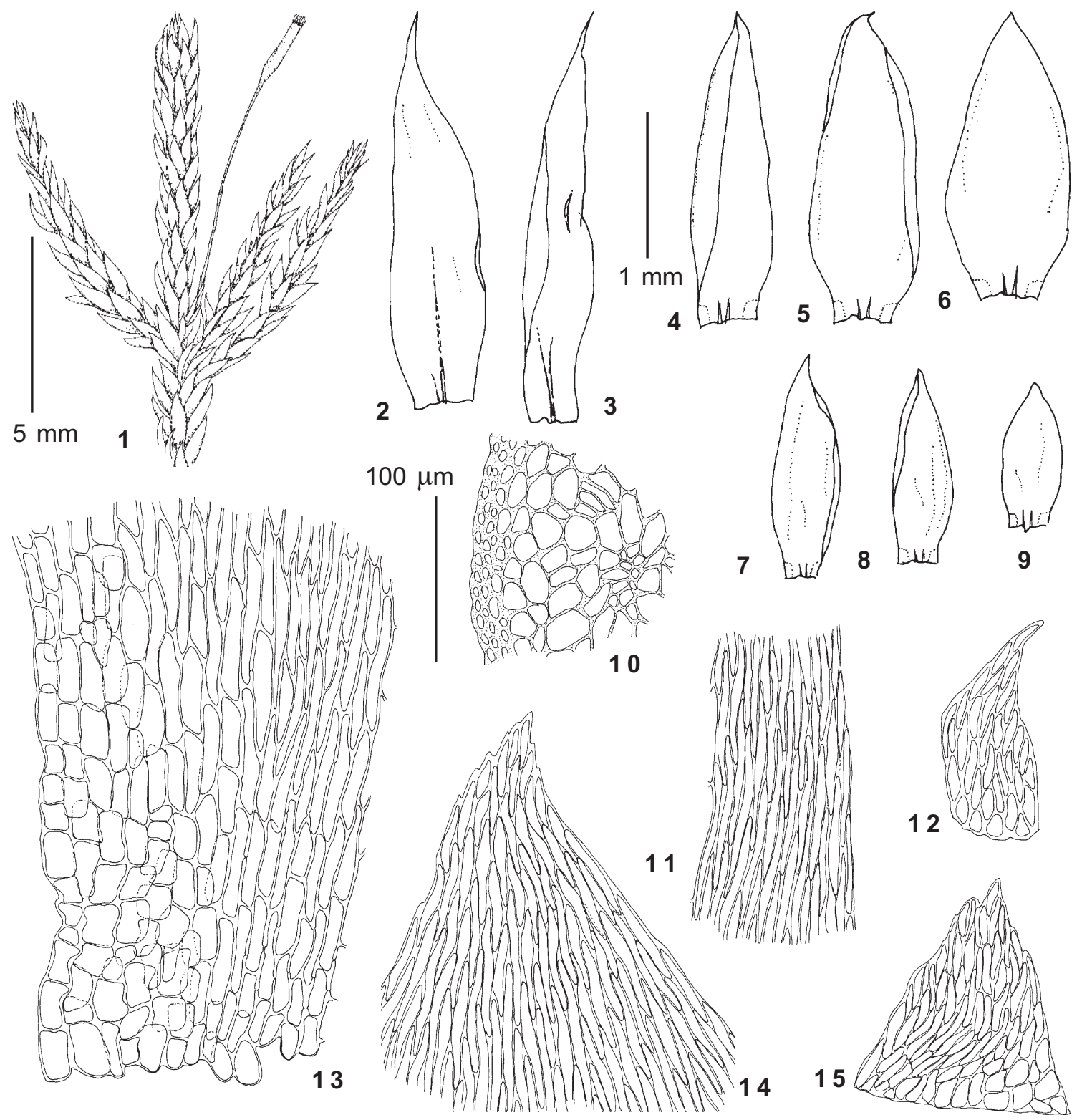

Fig. 4. Entodon schleicheri (Schimp.) Demeter (from Kobukhta $700 \mathrm{~m}$ Ignatov 0/247): 1 - habit; 2-3 perichaetial leaves; 4-6 - stem leaves; 7-9 - branch leaves; 10 - stem cross-section; 11 - middle laminal cells of stem leaf; 12, 15 - pseudoparaphyllia; 13 - alar cells of stem leaf; 14 - upper laminal cells of stem leaf. Scale bars: $5 \mathrm{~mm}$ - for $1 ; 1 \mathrm{~mm}$ - for $2-9 ; 100 \mu \mathrm{m}$ - for $10-15$.

Krylov (1925) reported in Altai Entodon concinnus (as E. orthocarpus), E. compressus and E. cladorrhizans (Hedw.) C. Müll., the latter name was probably applied to E. schleicheri. Bardunov (1974) added E. schleicheri but did not remove E. cladorrhizans, raising the total to therefore four species. However, we did not see any specimens of true E. cladorrhizans in collections from Altai, and therefore consider this species re- ported erroneously.

Differences between E. schleicheri and $E$. cladorrhizans.

In Europe both Entodon schleicheri and E. cladorrhizans are rare mosses, thus providing little opportunity for European bryologists of the first half of XIX century to understand the differences from North American plants of Entodon cladorrhizans (holotype in G!). 

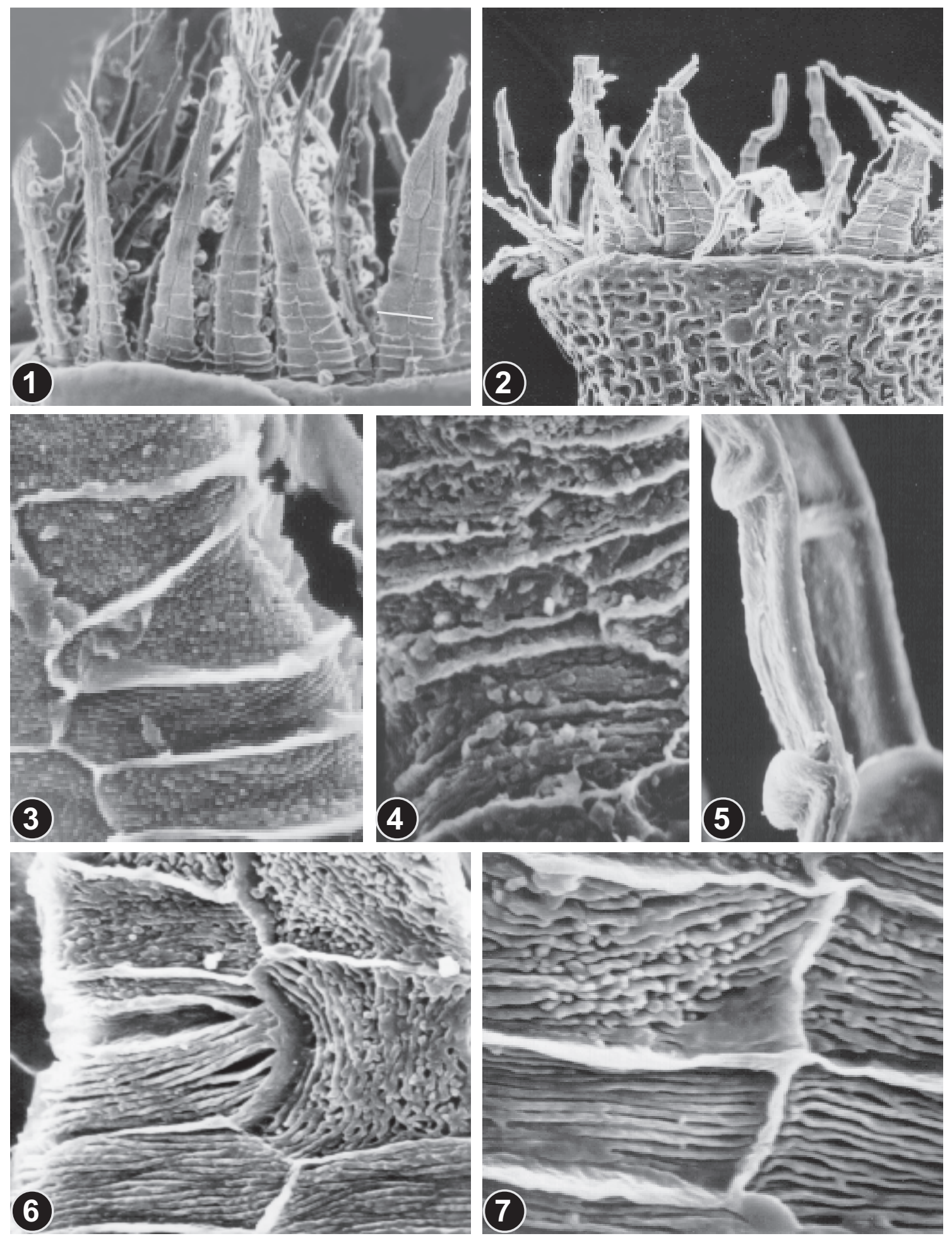

Fig. 5. Entodon schleischeri (Schimp.) Demeter from various regions (1, 3 - from Ural Mts., Bashkiria "Mosses of USSR, $N$ 65” (MHA), Ignatova 13.IX.1990; 2, 7 - from Altai, Malyi Yaloman Creek $1050 \mathrm{~m}$ Ignatov 25/108; 4 - from Moscow Province, Kunzevo, Zickendrath 27.IX.1989 (ex LE); 5-6 - from Altai, Chodro 880 m Zolotukhin 4.VII.1989): 1-2 - peristomes (1 - 200×; $2-270 \times)$; 3-4 - lower parts of exostome teeth, showing indistinct striolation (3-4 - 2100×); 5 - side view of exostome tooth in upper part $(2400 \times)$; 6-7 - lower parts of exostome teeth, showing distinct striolation $(6-2500 \times ; 7-3800 \times)$. 

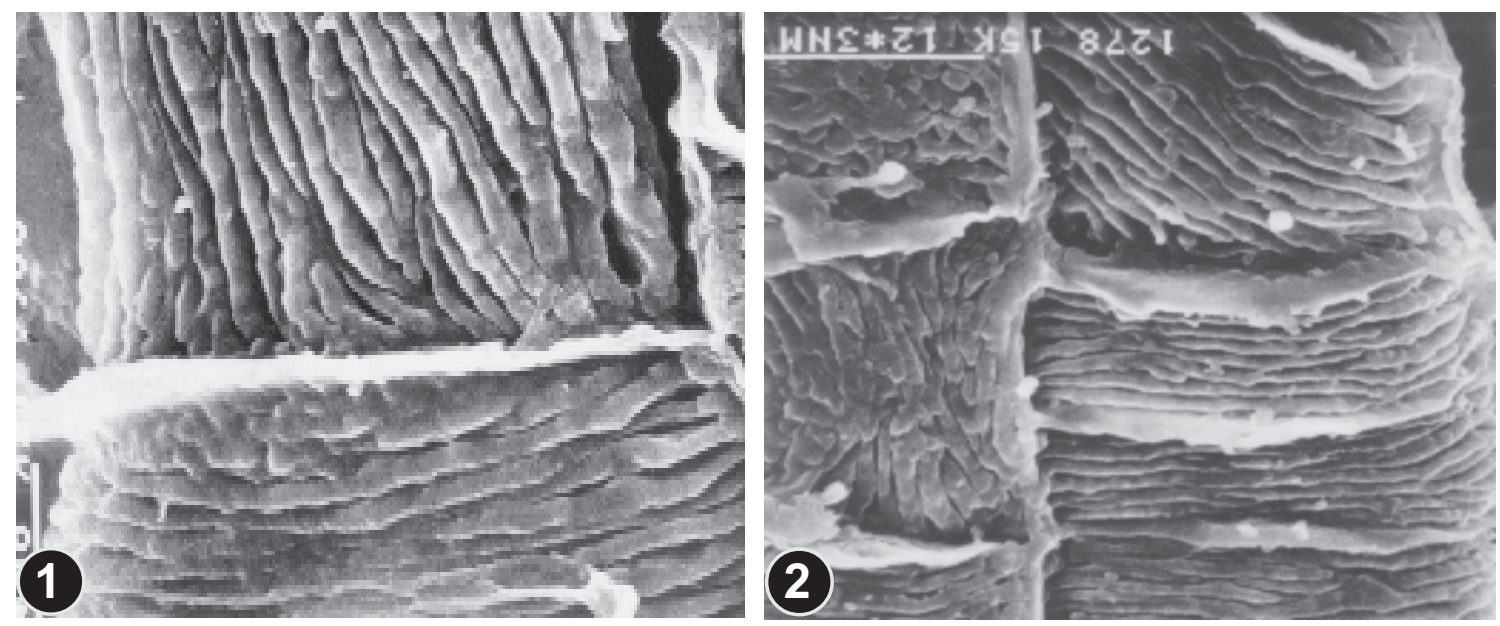

Fig. 6. Entodon schleischeri (Schimp.) Demeter from various regions (1 - Switzerland, Baden, Alonz 1895 (ex LE), 2 - Russian Far East, Primorsij Territory, Lazovskij Reserve Czerdantseva 2.IV.1987 (ex VLA)): lower parts of teeth, showing distinct striolation $(1-5400 \Psi ; 2-2700 \times)$.

Schimper was the first who found differences in annulus and exostome ornamentation between European and North American plants. He described Cylindrothecium schleicheri from exsiccates of Spruce and later thoroughly explained the differences of these species from American plants in Bryologia Europaea (1853). According to Schimper C. schleicheri differs in annulus absent (vs. present in C. cladorrhizans) and exostome teeth striolate (vs. papillose). However later he changed his mind and synonymizied Cylindrothecium schleicheri with C. cladorrhizans (Schimper, 1860). After that some authors have followed the former idea of Schimper, others - to the latter.

An important step toward understanding the species was taken by Demeter (1884), who found a specimen with annulus of 3 row of large cells (1-2 rows of elongate cells with slit-like lumen) and non-striolate exostome, and described it as Entodon transylvanicus Demeter. Later this species was found to be identical with E. cladorrhizans (Limpricht, 1895-1904). Since that time most European bryologists considered both $E$. cladorrhizans and E. schleicheri present in Europe. However these taxa were treated in different ways, so even in recent publications (Corley $\&$ al., 1981) it has been noted that this problem needs further study. In the North America $E$. cladorrhizans is more common, while E. schleicheri have been revealed in few places only recently (Buck \& Crum, 1978). We have studied several specimens of these species under both light microscope and SEM.

Entodon cladorrhizans from North America was found scarcely variable: all plants with a well-separating annulus have irregularly reticulate ornamentation. In E. schleicheri striolation on the outer surface of exostome was found rather variable. In most of specimens (from Far East, Siberia, West Europe, North America) papillae are fused in rather solid cristae (Figs. 5 (6-7) \& 6), resulting in a clear striolate pattern well seen under light microscope. However in some other specimens (Siberia, Urals, Central Russia) rather low round and homogeneous papillae form rather apparent rows, but solid cristae are developed only in scattered places or not at all (Figs. 5 (3-4)). Peristomes of the latter form look, under the light microscope, as indistinctly striolate to non-striolate. Nevertheless we attribute this form to E. schleicheri because of (1) annulus absence or weak expression, and (2) gradual transitions in exostome ornamentation. The form of E. schleicheri with "indistinct-striolate" exostome has often been considered as E. cladorrhizans s. str. (for example in the Moscow Province of Russia). The only specimen of E. cladorrhizans from Eurasia seen by us is the holotype of E. transylvanicus (Fig. 7). All other non-American collections in MHA, MW, LE and H studied belong to E. schleicheri. Several specimens were seen from China, and all of them appear to be 

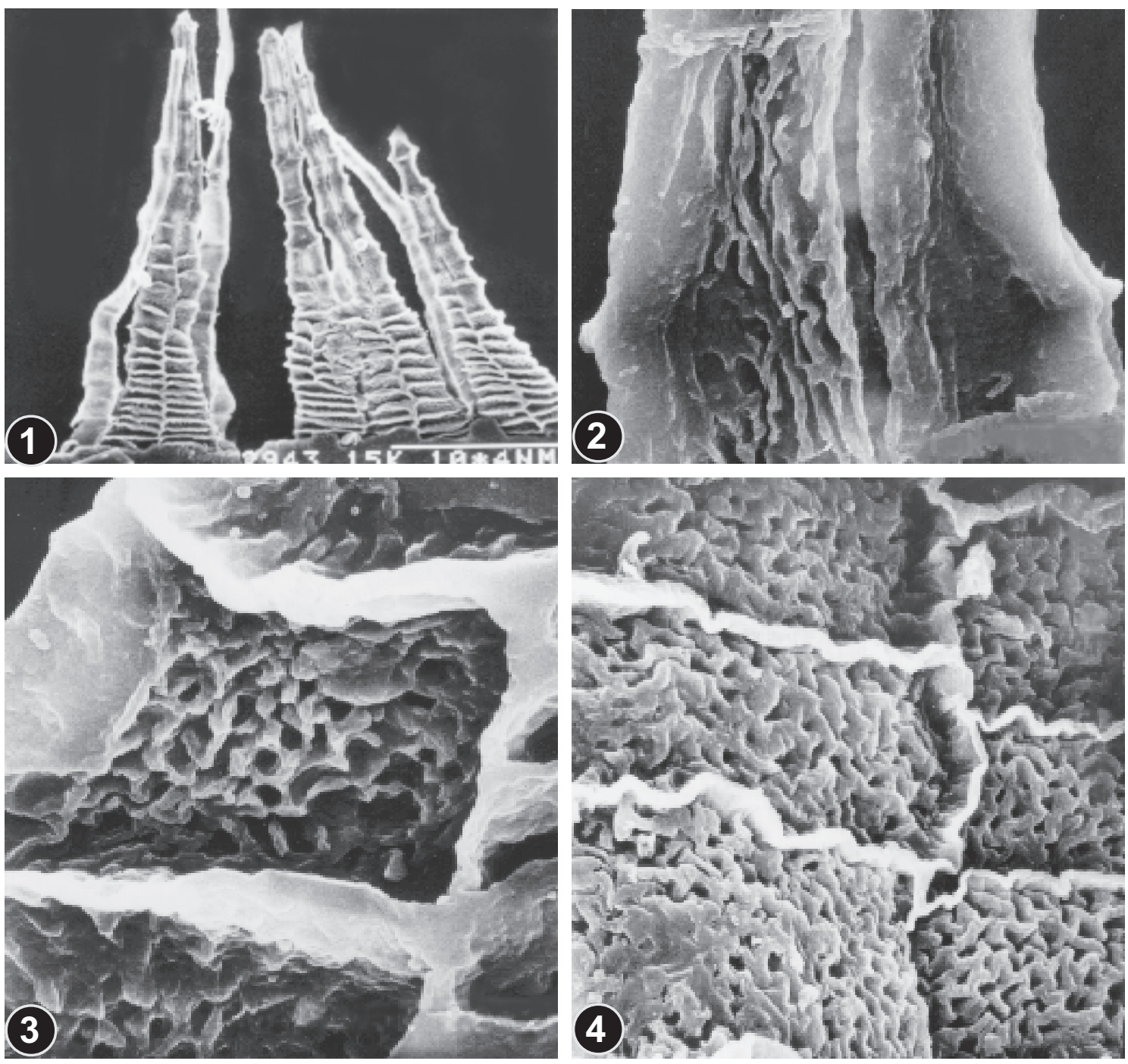

Fig. 7. Entodon cladorrhizans (Hedw.) C. Müll. from various regions (1-3 - Romania, isotype of E. transsylvanicus Demeter (ex H); 4 - North America, New Mexico, Ikonberg 395 (ex NY)). 1 - peristome (360×); 2 - outer exostome tooth in upper third $(3600 \times)$; 3-4 - lower parts of teeth, showing reticulate ornamentation pattern $(3-53004$; 4 $4000 \times)$.

E. schleicheri. Since Hu (1983) mentioned for China only one species of this pair (E. cladorrhizans), we can conclude that only one species occurs there, and it is E. schleicheri.

Distribution: Entodon schleicheri in the sense mentioned above has scattered localities in several countries of Central Europe (Austria, Germany, France, Italy, Jugoslavia, Romania, Switzerland, Czechia), Central Russia (Moscow Province), Urals and Caucasus, and very common in mountains of South Siberia, Russian Far East, Korea, and mainland China (south to Yunnan). Also this species occurs in western U. S. A. and in Mexico. In Altai is is very common in more wet areas of Northern Altai, growing at lower elevations on fresh logs, rarely on trunks of living trees, sometimes on rock outcrops (usually on layer of humus), always in more or less exposed habitats. In Central Altai this species occurs sometimes in rather xeric areas, but there only in valleys, on Betula and Populus trunks.

Specimens examined: Anos $400 \mathrm{~m}$ (Anonymous 17.VIII.1909 LE!); Bele $500 \mathrm{~m}$ (0/67); Bolshoi Yaloman Creek, in middle course $1500 \mathrm{~m}$ (Makarov \& al. 15.VII.1972); Chemal 450 m (Schteinberg 8.IX.1931 LE!) (29/74); Chemal Creek, 3 km upstream $450 \mathrm{~m}(34 / 64)$; Chemal, $10 \mathrm{~km}$ upstream along Katun $450 \mathrm{~m}(34 / 55)$; Chodro 880 m (Zolotukhin 4.VII.1989); Chulcha River, 


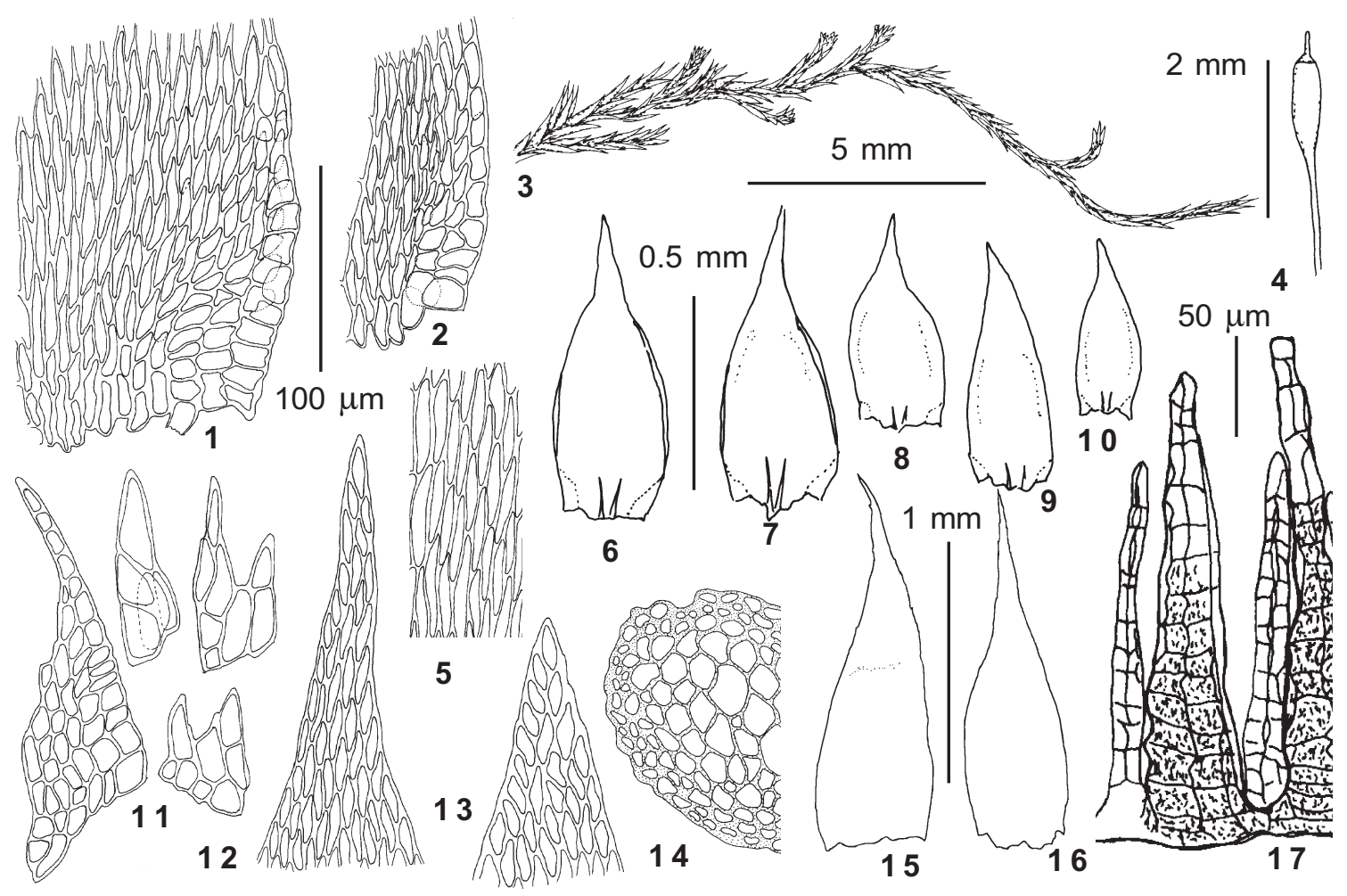

Fig. 8. Platygyrium repens (Brid.) B.S.G. (from Chiri Creek, $0.5 \mathrm{~km}$ upstream $450 \mathrm{~m}$ Ignatov 17/91): 1 - alar cells of stem leaf; 2 - alar cells of branch leaf; 3 - habit; 4 - capsule; 5 - middle laminal cells of stem leaf; 6-8 stem leaves; 9-10 - perichaetial leaves; 11 - pseudoparaphyllia; 12 - upper lamina cells of stem leaf; 13 - upper lamina cells of branch leaf; 14 - stem cross-section; $15-17$ - branch leaves. Scale bars: $5 \mathrm{~mm}$ - for 3; 2 mm - for 4 ; $1 \mathrm{~mm}$ - for $9-10 ; 0.5 \mathrm{~mm}$ - for $6-8,15-17 ; 100 \mathrm{mkm}$ - for $1-2,5,11-14$.

in middle course $1000 \mathrm{~m}(9 / 134 ; 9 / 160), 1100 \mathrm{~m}(9 /$ 122); Elekmonar Creek, 25 km upstream $1100 \mathrm{~m}$ (26/72); Elekmonar Creek, 5 km upstream 700 m (26/39); GornoAltaisk $400 \mathrm{~m}$ (35/13); Kairu Creek, 6 km upstream 900 $\mathrm{m}(15 / 152 ; 15 / 84) ;$ Kobukhta $700 \mathrm{~m}(0 / 247) ;$ Kyrsai $450 \mathrm{~m}$ (Schischkin 7.IX.1931 LE!); Maima $280 \mathrm{~m}$ (35/ 19); Malyi Yaloman Creek, 5 km upstream $900 \mathrm{~m}$ (25/ 118); Malyi Yaloman Creek, 7 km upstream $1050 \mathrm{~m}$ (25 108); Yailyu $450 \mathrm{~m}(0 / 1000 ; 0 / 999), 470 \mathrm{~m}(0 / 998)$.

Platygyrium B. S. G.

The genus includes 3-5 species in temperate regions of the Northern Hemisphere, one of which has a wide distribution in the Holarctic. Platygyrium differs from Entodon in small plants, dioicous sexuality and brood branches in leaf axils.

Platygyrium is often considered to be close to Pylaisiella. Their similarities include erect capsules, peristome reduction and straight leaves. However the peristome reduction in Pylaisiel$l a$ is confined only to imperfect cilia, while in Platygytium the endostome has a low basal membrane, with narrow, non-perforate segments. Exostome teeth in Platygyrium are unusually small for the Hypnaceae $(0.15 \mathrm{~mm}$, cf. $0.30 \mathrm{~mm}$ in Pylaisiella polyantha), without typical papillose to striolate ornamentation on the outer surface and with smooth ventral trabeculae, while in Pylaisiella the exostome teeth are papillose, often with branched papillae, and with incrassate papillose ventral trabeculae. Also, Platygyrium and Pylaisiella differ in their pattern of hygroscopic movement of the peristome (in Platygyrium the teeth cover the mouth when wet, while in Pylaisiella they are erect when wet). So, there are no reasons to consider these genera to be closely related.

Platygyrium repens (Brid.) B.S.G., Bryol. Eur. 5: 98. t. 458. 1851. - Pterigynandrum repens Brid., Muscol. Recent. Suppl. 1: 131. 1806.

Figs. $8 \& 9$

Plants small, dark-green in older parts, with lighter and \pm glossy young shoots. Stem to $2 \mathrm{~cm}$ long, without central strand, \pm regularly pinnate-branched, branches 3-4 mm long. Pseudoparaphyllia lanceolate, short. Axillary hairs 3-celled, $80 \mu \mathrm{m}$ long, apical cell $40 \times 11 \mu \mathrm{m}$. Rhizoids below leaf insertions or around brood branches or in leaf axils where brood branch- 

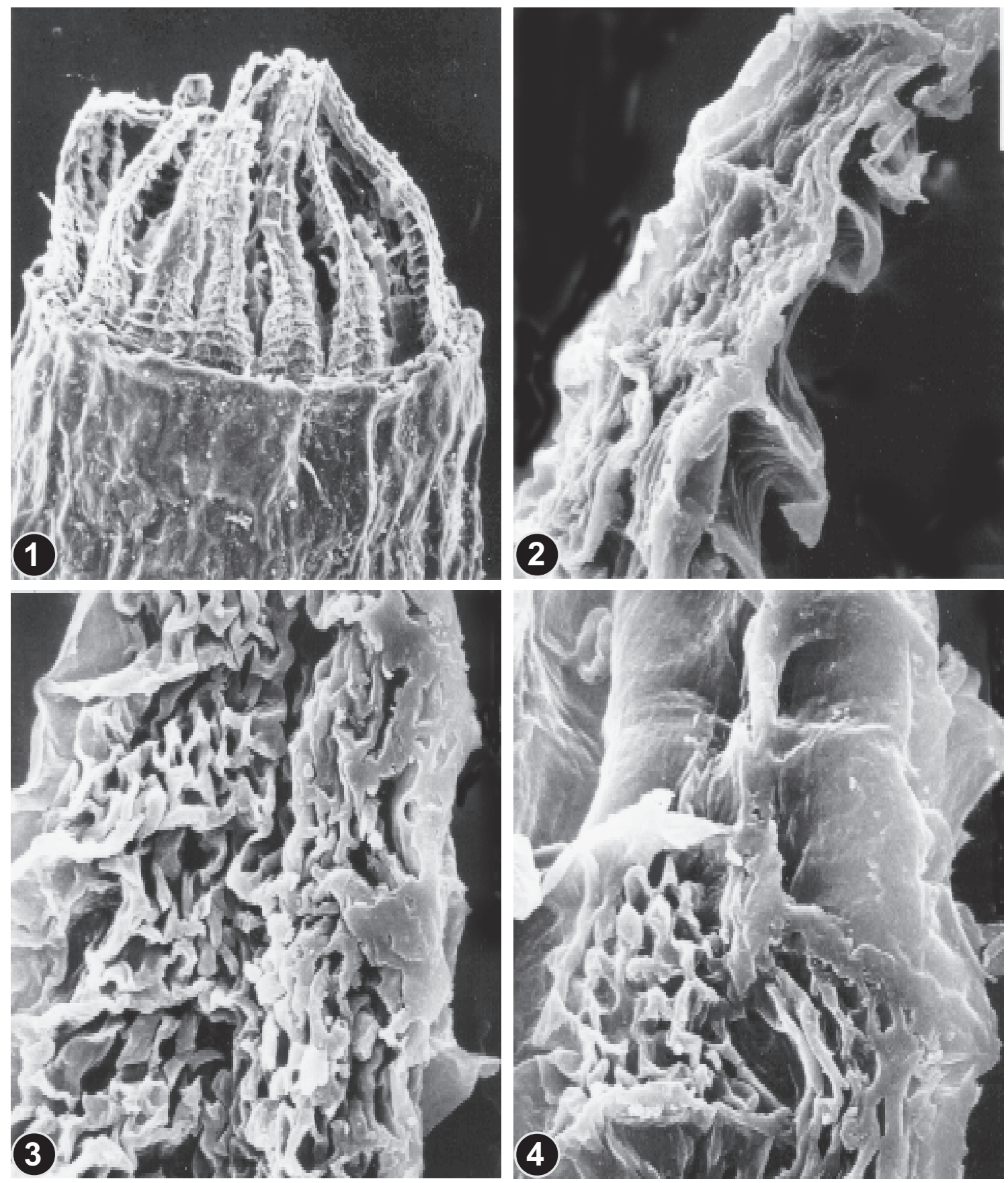

Fig. 9. Platygyrium repens (Brid.) B.S.G. (from Moscow Province, “Mosses of USSR, N 30” (MHA) Ignatov 11.VI.1988): 1 - peristome (440×); 2 - side view of exostome tooth in upper third (3500×); 3 - outer surface of exostome tooth in lower third (5200×); 4 - outer surface of exostome tooth in transition zone $(5200 \times)$.

es could develop; some rhizoids granulose and purplish. Stem leaves \pm straight, 0.7-1.2 ×0.3-0.4 mm, ovate, shortly acuminate; margins entire and recurved. Branch leaves 0.4-0.6 $\times 0.2 \mathrm{~mm}$. Laminal cells (35-) $60-90 \times 8(5 / 3) \mu \mathrm{m}$; in alar regions cells subquadrate, numerous.
Dioicous. Sporophytes rather frequent. Perichaetial leaves 1.4-1.5 $\times 0.4-0.5 \mathrm{~mm}$, spreading; alar regions wide and extending along the margin, forming distinct borders. Seta $1.5 \mathrm{~cm}$. Capsule ca. $1.5 \mathrm{~mm}$ long, straight. Annulus of 2 rows of round cells. Operculum conic-rostrate. Exostome teeth straight when 
dry, $0.15 \mathrm{~mm}$ long, gradually tapered, entire; in the lower $2 / 3$ reticulate (proximally with more transverse orientation of cristae, distally with more longitudinal), in the upper part smooth to irregularly rugose; dorsal trabeculae low; margins non-incrassate; ventral trabeculae smooth. Endostome with very low basal membrane, segments narrow and ca. $0.12 \mathrm{~mm}$ long, cilia none. Spores 11-14 $\mu \mathrm{m}$.

Well-developed extensive mats of Platygyrium are easy to recognize by rather small dull dark-green plants with numerous brood branches in leaf axils. However the young parts of plants are \pm shiny, Pylaisiella-like and usually need microscopic study. Recurved leaf margins are suggestive in this case. Fortunately $P$. repens is often found with sporophytes and have setae much longer than in Pylaisiella.

Distribution: Platygyrium repens is widespread in the temperate and hemiboreal zones of Europe, North Africa and North America. In Asia it occurs in South Siberia and Russian Far East, Korea, Japan and in northern and northwestern China. In Altai it occurs mostly at elevations lower than $1200 \mathrm{~m}$, avoiding true boreal forests. Nearly all the collections were made from rotten logs or from upper surfaces of inclined trunks.

Specimens examined: Adylda Creek 1100 m (34/79); Anos 360 m (465; Vereshchagin 22.VI.1911 LE!); Bolshoi Mianok Creek, at mouth 440 m (Zolotukhin 8.VIII.1988); Chemal Creek, 3 km upstream $450 \mathrm{~m}(34 / 67$; 34/68); Chiri Creek, $0.5 \mathrm{~km}$ upstream $450 \mathrm{~m}(17 / 8 ; 17 / 91)$; Elekmonar Creek, 5 km upstream 700 m (26/35); Kaitanak Creek 1200 m (Bondartzeva 1.VIII.1968 LE!); Korbu 440 m (Zolotukhin 20.X.1988); Kuba Creek, $5 \mathrm{~km}$ apart from Chemal $500 \mathrm{~m}$ (Makarov 3.VI.1972); Ok-Porok Creek, at mouth $440 \mathrm{~m}$ (Zolotukhina 30.III.1988); Shebalino 800 m (Seman 15.VII.1970 LE!); Shebalino deer farm $1000 \mathrm{~m}$ (Palamarchuk 23.VIII.1969 LE!); Yailyu $450 \mathrm{~m}(1 / 46), 480 \mathrm{~m}(0 / 625)$; between AkKem and Kochurla Creeks (Krylov 27.VII.1903 LE!).

Plagiotheciaceae (Broth.) Fleisch.

In the current literature the contents of this family within the Holarctic is usually accepted either for Plagiothecium + Isopterygium \& related genera (following Fleischer, 1912, etc.), or for Plagiothecium only, leaving other genera to Hypnaceae (Fleischer, 1923; Brotherus, 1925, etc). Recently Hedenäs $(1987,1989)$ found that rhizoid topography and some other characters define a group of genera of otherwise unclear position - Myurella, Orthothecium, Isopterygiopsis, Platydictya, and Herzogiella. These genera appear close to each other, and closer to Plagiothecium than to any part of the Hypnaceae, so Hedenäs referred them to Plagiotheciaceae. This position is accepted in general in this paper.
The Plagiotheciaceae are delimited by a number of synapomorphic characters, presented in at least some species of the genera: (1) branching rare, irregulary fasciculate; (2) branches fragile, growing in the early stages at acute angle with the stem; (3) lack of pseudoparaphyllia; (4) rhizoid position in leaf axil or on the abaxial face of leaf, or in indefinite position, but not below the leaf insertion; (5) rhizoids papillose and purple; (6) axillary hairs very thin; (7) stem and branch leaves non-differentiated; (8) exostome teeth pale; (9) outer surface of exostome above the transition zone smooth or with rare minute papillae; (10) gemmae in leaf axils or abaxial on leaf.

Hedenäs (1989) included Taxiphyllum (and Isopterygium) in the Plagiotheciaceae. However Taxiphyllum has (1) rhizoids below the leaf insertion; (2) foliose pseudoparaphyllia; (3) no gemmae; (4) more regularly pinnate branching. We place this genus in Hypnaceae, as did Brotherus (1925), Ireland (1986), Inoue \& Iwatsuki (1987), etc., although within the Hypnaceae Taxiphyllum (and probably also Isopterygium) has no obvious relatives.

\section{Isopterygiopsis Iwats.}

Iwatsuki (1970) described this genus for only one species, I. muelleriana, but later added also I. pulchella (Iwatsuki, 1987), since it was found closer to I. muelleriana, than to other species of the large, heterogeneous Isopterygium. Important differences from the latter include (1) axillary papillose rhizoids; (2) lack of pseudoparaphyllia; (3) epidermal layer of stem composed of thin-walled cells. The genus includes 3 species, all present in Altai.

\section{KEY TO THE ALTAIAN SPECIES OF ISOPTERYGIOPSIS}

1. Epidermal cells of stem as large as those of the subtending layer; leaves indistinctly complanate, linear-lanceolate; plants autoicous, often producing sporophytes

................... I. pulchella (p. 36)

1. Epidermal cells of stem markedly larger than those of the subtending layer (see cross section); plants dioicous, sporophytes never found in Altai . . . . . . . . . . . . . 2

2. Plants small to medium-sized, distinctly complanate ...... I. muelleriana (p. 36)

2. Plants very small, with rather short leaf cells ............. I. alpicola (p. 38) 

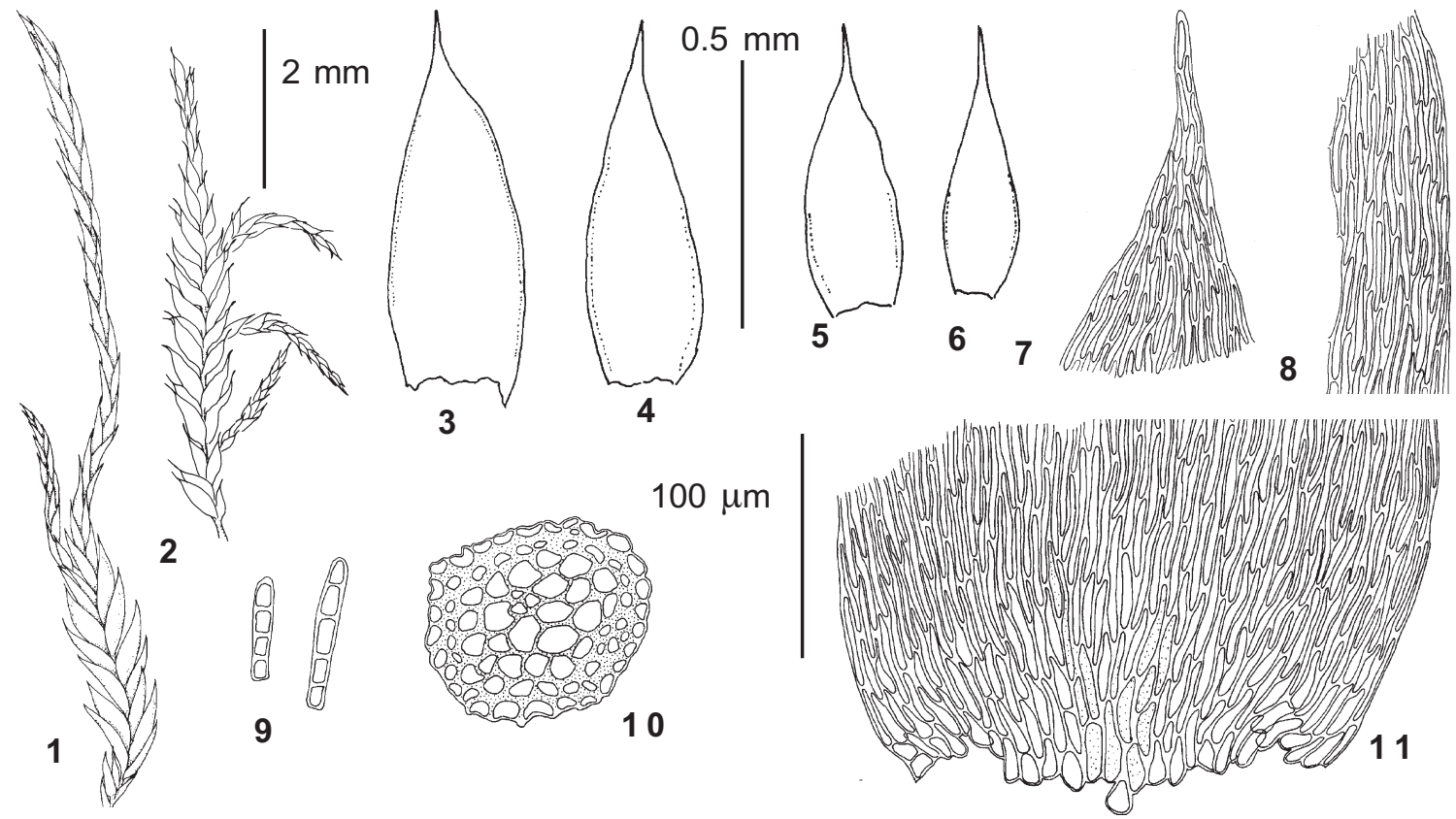

Fig. 10. Isopterygiopsis muelleriana (Schimp.) Iwats. (from Kamga Creek, 14 km upstream $600 \mathrm{~m}$ Ignatov 0/111): 1-2 - habit; 3-6 - leaves; 7 - upper laminal cells; 8 - middle laminal cells; 9 - gemmae; 10 - stem cross-section; 11 - cells of leaf base. Scale bars: $2 \mathrm{~mm}$ - for $1-2 ; 0.5 \mathrm{~mm}-$ for $3-6 ; 100 \mu \mathrm{m}$ - for 7-11.

Isopterygiopsis muelleriana (Schimp.) Iwats., J. Hattori Bot. Lab. 33: 379. 1970. - Plagiothecium muellerianum Schimp., Syn. Musc. Eur. 584. 1860.

Fig. 10

Plants small to medium-sized, intricate and green or yellow-green, distinctly complanate. Stem prostrate, ca. $2.5 \mathrm{~cm}$ long, with hyalodermis and central strand, irregularly loose branched. Axillary hairs 3celled, $190 \mu \mathrm{m}$ long, apical cell to $95 \times 7-9 \mu \mathrm{m}$. Leaves $0.7-0.9 \times 0.2-0.3 \mathrm{~mm}$, oblong-ovate, entire, densely arranged, usually overlapping. Laminal cells 40-60 $\times$ $3.5 \mu \mathrm{m}$. Alar cells not differentiated. Gemmae in leaf axils 4-5-celled, uniseriate, 55-75(-85) × 9-11 $\mu \mathrm{m}$.

Dioicous. No sporophytes have been seen in Altaian plants (or in neighboring regions).

Isopterygiopsis muelleriana is easy to know by small to medium-sized plants with a distinctly complanate habit, growing mostly on wet rocks. Very characteristic are some parts of stem where leaves are much smaller; such zones are usually on shoot ends, but sometimes they grow further into normally foliated shoots.

Distribution: Isopterygiopsis muelleriana has a scattered distribution throughout the Holarctic, in more southern mountains and oceanic regions. In South Siberia and Russian Far East it is known from nearly all the places where careful studies were undertaken; the species is known from South and
Central Europe, Caucasus, Himalayas, Sichuan, northeastern China, and Japan. However it was not found in Mongolia and Xinjiang, probably because of generally xeric conditions. In Altai it has been found in the forest- and subalpine belts, typically on moist or wet sides of rock outcrops (usually on \pm basic schists).

Specimens examined: Bayas Lake $1750 \mathrm{~m}$ (0/240); Bolshoi Shaltan Creek 580 m (0/1241); Kamga Bay 450 m (Zolotukhin 11.VII.1988); Kamga Creek, 14 km upstream $600 \mathrm{~m}(0 / 111), 630 \mathrm{~m}(0 / 1251)$; Kayakkatuyarykskij Creek $1760 \mathrm{~m}(8 / 14), 1800 \mathrm{~m}(8 / 228), 1900 \mathrm{~m}(8 /$ 315), 2000 m (3/41), 2050 m (7/39); Kobiguayuk Creek $2180 \mathrm{~m}(0 / 1237)$; Maloye Istyube Creek, $1 \mathrm{~km}$ upstream $600 \mathrm{~m}$ (Zolotukhin 19.V.1977); Srednij Shaltan Creek $730 \mathrm{~m}(0 / 1243)$; Yailyu $450 \mathrm{~m}(0 / 1252 ; 1 / 17)$.

Isopterygiopsis pulchella (Hedw.) Iwats., J. Hattori Bot. Lab. 63: 450. 1987. - Leskea pulchella Hedw., Sp. Musc. 220. t. 55: f. 7-12. 1801.

Figs. 11 \& 12

Plants small, green to yellow-green. Stem 2-2.5 cm long, irregularly branched; epidermal cells small, but rather thin-walled; central strand present. Axillary hairs 2-celled, $65 \mu \mathrm{m}$ long, apical cell $57 \times 6 \mu \mathrm{m}$. Leaves erect-spreading to somewhat falcate (in more xeric conditions), (0.5-) 0.8-1.0 $\times 0.2 \mathrm{~mm}$, lanceolate to ovate-lanceolate. Laminal cells $85-130 \times 4 \mu \mathrm{m}$. Basal cells shorter, not differentiated in alar regions. Gemmae in leaf axils, 3-4-celled.

Autoicous. Sporophytes frequent. Inner perichaetial leaves to $0.5 \times 0.1 \mathrm{~mm}$, smooth. Seta $0.8-1.2 \mathrm{~cm}$. 


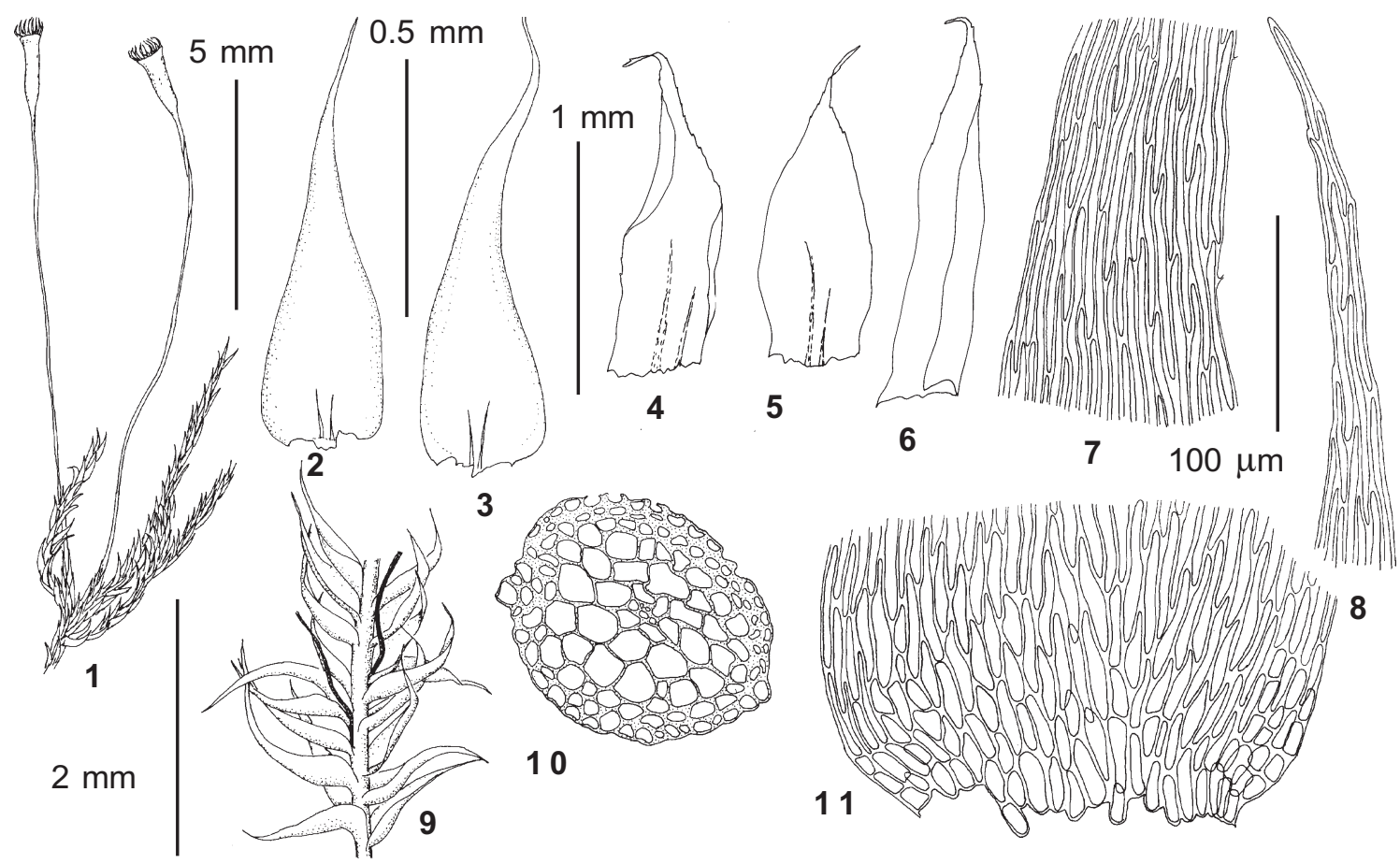

Fig. 11. Isopterygiopsis pulchella (Hedw.) Iwats. (from Tabozhok Peak $2350 \mathrm{~m}$ Ignatov 31/99): 1 - habit; 23 - leaves; 4-6 - perichaetial leaves; 7 - middle laminal cells; 8 - upper laminal cells; 9 - stem portion; 10 - stem cross-section; 11 - cells of leaf base. Scale bars: $5 \mathrm{~mm}$ - for $1 ; 2 \mathrm{~mm}$ - for $9 ; 1 \mathrm{~mm}$ - for 4-6; $0.5 \mathrm{~mm}-$ for 2 $3 ; 100 \mu \mathrm{m}-$ for $7-8,10-11$.

Capsule ca. $1.0 \mathrm{~mm}$ long, straight to rarely somewhat curved. Annulus of 2 rows of cells, deciduous. Operculum conic. Exostome teeth ca. $0.35 \mathrm{~mm}$ long, gradually tapered, entire, reflexed when dry; in the lower part striolate, with cristae wavy and somewhat papillose; in the middle cristae becoming oblique to longitudinal and with overlying papillae, or sometimes forming a reticulate pattern (with longitudinally elongated loops); in the upper part with rare low irregularly arranged papillae, low dorsal trabeculae, non-incrassate margin, and smooth ventral surface and trabeculae. Endostome $0.40 \mathrm{~mm}$ long, basal membrane 0.10 $\mathrm{mm}$ high, segments narrow and non-perforate; cilia rather short and nodose to reduced. Spores 10-15 $\mu \mathrm{m}$.

Isopterygiopsis pulchella can be recognized in the field by numerous pale capsules, similar to those of Plagiothecium laetum, and subjulaceous habit.

Distribution: Isopterygiopsis pulchella is a moss of cool climate of both hemispheres. It is widespread in the Arctic (including Svalbard, Franz-Josef Land, northern Greenland, etc.) and northern boreal forests and also high mountains throughout the Holarctic. It is common in Mongolia, but in China was reported only from the northern provinces, Heilongjiang and Xinjiang. In Altai I. pulchella is very common in the taiga belt at ca. 1500-2000 m, where it grows on rotten logs and on soil at upturned roots of fallen trees. It is not rare locally in the alpine zone, especially in more xeric areas of southeastern Altai, where it grows among rocks as well as on soil in tundras.

Specimens examined: Bashkaus River, upper course $2250 \mathrm{~m}$ (36/380a); Bayas Lake 1750 m (0/659), $2100 \mathrm{~m}$ (0/1036); Bogoyash Creek, upper course $2400 \mathrm{~m}$ (36/ 334a), $2550 \mathrm{~m}(36 / 246)$; Chainary Creek, upper course $1800 \mathrm{~m}$ (34/196); Chiri Creek, $0.5 \mathrm{~km}$ upstream $450 \mathrm{~m}$ (17/111); Chulcha River, in middle course $850 \mathrm{~m}$ (Zolotukhin 10.IX.1989); Kairu Creek, 8 km upstream $1000 \mathrm{~m}$ (15/101; 15/48; 15/90); Karakol Lakes 1900 m (26/ 122; 28/71); Kayakkatuyarykskij Creek $1650 \mathrm{~m}$ (8/131), $1900 \mathrm{~m}(8 / 320 ; 8 / 337), 1920 \mathrm{~m}(3 / 159 ; 3 / 219 ; 3 /$ 253), $1940 \mathrm{~m}(3 / 243), 2050 \mathrm{~m}(3 / 4 ; 7 / 147)$; Kobiguayuk Creek $2030 \mathrm{~m}$ (0/1037), $2200 \mathrm{~m}$ (0/1038; 0/1707), 2500 m (0/301); Kokkul Lake 2300 m (33/13); Kokorya Creek $2150 \mathrm{~m}(32 / 19), 2400 \mathrm{~m}(32 / 18)$; Kukol $1780 \mathrm{~m}$ (0/1035), $1800 \mathrm{~m}(0 / 1034 ; 0 / 1039), 1850 \mathrm{~m}(0 / 660)$; Malaya Kokorya Creek 2450 m (36/287); Saluru Creek, upper course $2250 \mathrm{~m}(36 / 293)$; Sondrukat Creek, upper course $2000 \mathrm{~m}$ (Zolotukhin 13.VI.1988); Tabozhok Creek, 12 km upstream $2200 \mathrm{~m}(30 / 46)$; Tabozhok Peak $2150 \mathrm{~m}$ (31/105), $2300 \mathrm{~m}(31 / 103 ; 31 / 98), 2350 \mathrm{~m}(31 / 100$; 31/99), $2550 \mathrm{~m}$ (31/97), $2750 \mathrm{~m}$ (31/102); Tokpak Creek, in middle course $2800 \mathrm{~m}(36 / 389 \mathrm{a})$; Yailyu $450 \mathrm{~m}$ (1/ 9); Yakhansoru Lake $2000 \mathrm{~m}$ (Zolotukhin 26.VI.1990). 

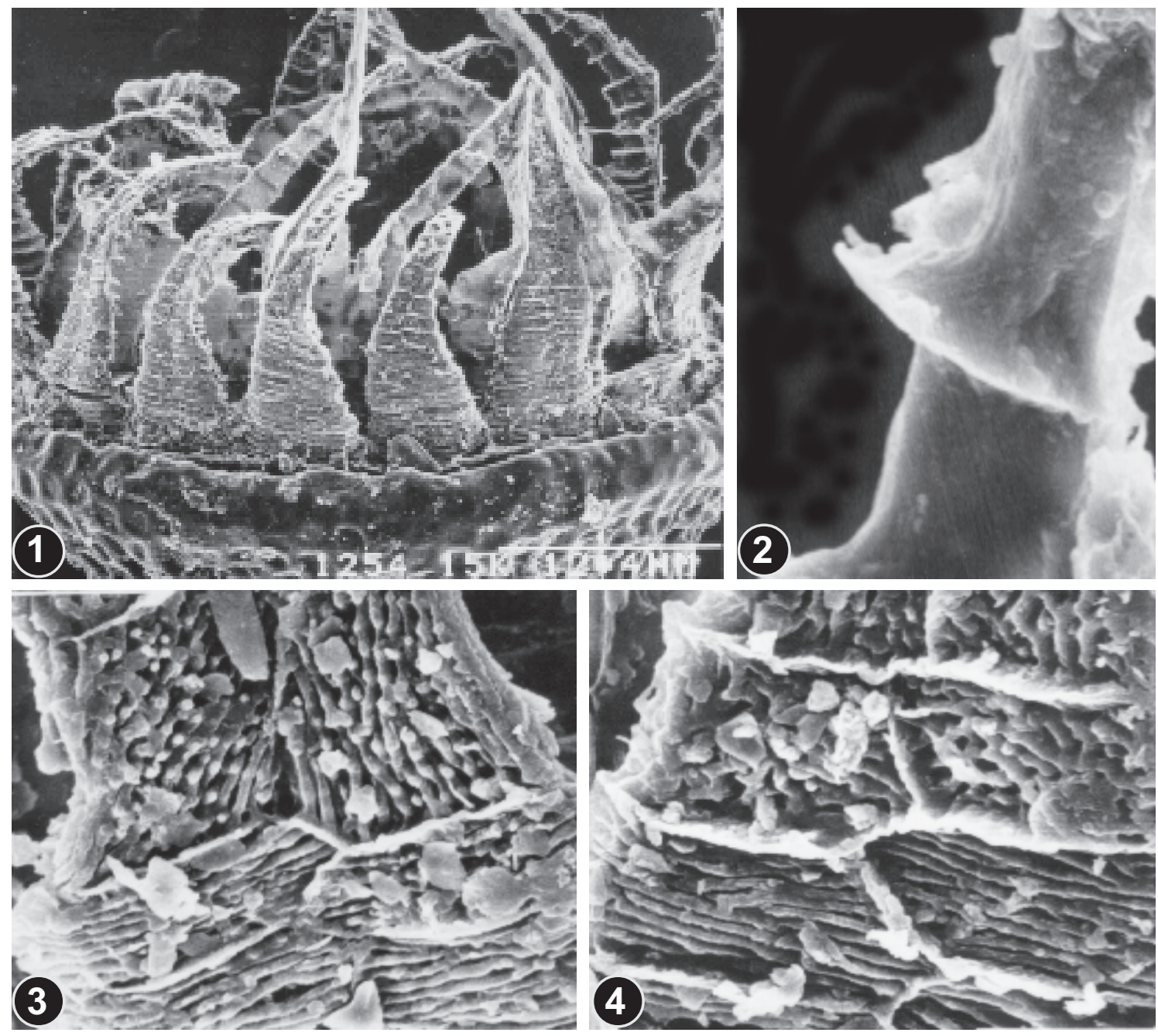

Fig. 12. Isopterygiopsis pulchella (Hedw.) Iwats. (from Saluru Creek $2250 \mathrm{~m}$ Ignatov 36/293): 1 - peristome $(350 \times) ; 2$ - inner surface of exostome tooth in upper part, showing smooth inner trabecula (4800×); 3 - outer surface of exostome tooth above the transition zone $(3000 \times) ; 4-$ outer surface of exostome tooth below the transition zone $(4800 \times)$.

Isopterygiopsis alpicola (Lindb. et H. Arnell) Неdenдs, J. Bryol. 15: 495. 1988. - Stereodon alpicola Lindb. et H. Arnell, Kongl. Sv. Vet. Acad. Handl. 23(10): 153. 1890. Fig. 13

Holotype: Siberia, Jenisei, Uskij Mys, 61ํำ $\mathrm{N}$, in schists 5.VII.1876 H. W. Arnell (S!).

Plants small, in rather dense green opaque tufts. Stem $1.5 \mathrm{~mm}$ long, loosely foliate, with strongly enlarged epidermal cells, with central strand, $15 \mathrm{~mm}$ long, very rarely branched. Axillary hairs 2-celled, $50 \mu \mathrm{m}$ long, apical cell $45 \times 4 \mu \mathrm{m}$. Leaves somewhat falcate, $0.3-0.35 \times 0.1-0.15 \mathrm{~mm}$, ovate, shortly acuminate; margins serrulate throughout. Laminal cells 25$40(-55) \times 6-8(5-6 / 1-2) \mu \mathrm{m}$, often irregular in shape. Alar cells shorter, forming a small indistinct group.

Dioicous? Sporophytes unknown. Gemmae in leaf axils 3-celled, ca. $45 \times 9 \mu \mathrm{m}$.

Isopterygiopsis alpicola is a small plants, superficially somewhat similar to small forms of $I$. pulchella, but differs in dioicous sexual condition, serrulate leaves, shorter laminal cells and large epidermal cells. The differences from Platydictya jungermannioides include the presence of central strand (ill-developed in thinner shoots), large epidermal cells of the stem, and differences in gemma shape (cf. Figs. 13 \& 14) - in Isopterygiopsis gemmae are composed of a row of 3-4 elongate cells of the same width, while in Platydictya the cells are shorter, and gemmae have an obcuneate shape due to the wider distal end of the distal cell, which is often slightly lobed. 

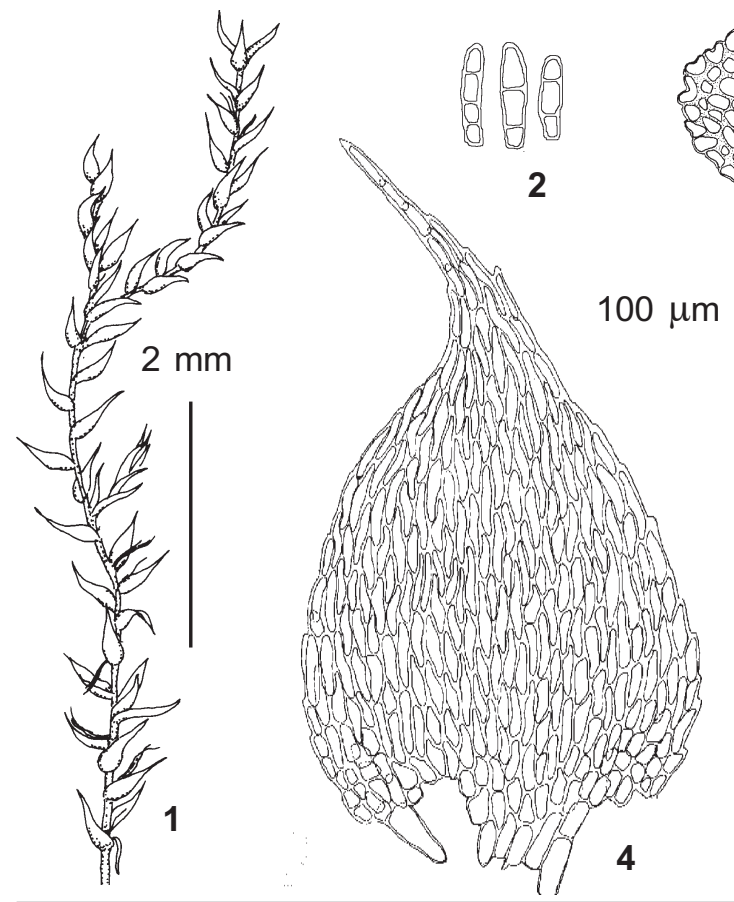

Distribution: This is a very rare moss worldwide. We have seen three specimens from Siberia ((1) type; (2) one collection from Altai; (3) Middle course of Yenisej River, $63^{\circ} 20^{\prime} \mathrm{N}-91^{\circ} 9^{\prime} \mathrm{E}$, Szerbina 139, MW); one collection from Amurskaya Province of the Russian Far East $\left(53^{\circ} 52^{\prime} \mathrm{N}-127^{\circ} 19^{\prime} \mathrm{E}, 350 \mathrm{~m}\right.$ alt., L. I. Abramova, s. n., MW!); and several collections from Sweden and Finland (in S!).

Specimens examined: Kayakkatuyarykskij Creek 1900 $\mathrm{m}(8 / 337)$.

\section{Platydictya Berk.}

For a long time Amblystegiella, nom. illeg. and later Platydictya have been considered in a wide sence, including small mosses without central strand and with costa faint or absent.
Fig. 13. Isopterygiopsis alpicola (Lindb. et $\mathrm{H}$. Arnell) Hedenäs (from Kayakkatuyarykskij Creek 1900 m Ignatov 8/337): 1 - habit; 2 - gemmae; 3 - stem cross-section; 4-5 - stem leaves. Scale bars: $2 \mathrm{~mm}$ - for $1 ; 100 \mu \mathrm{m}-$ for 2-5.
However Hedenäs (1987) showed that $P$. jungermannioides, the type of the genus, is distinct from other widespread Holarctic species, P. subtilis (Hedw.) Crum and P. confervoides (Brid.) Crum. As to the latter two species, Söderström \& al. (1992) suggested to place them in Serpoleskea (Limpr.) Warnst., a genus typified by Leskea subtilis Hedw. (= Serpoleskea subtilis (Hedw.) Loeske). It needs a further study to understand if other Chinese and North American species referred to Platydictya belong to this genus or to Serpoleskea.

Among the pleurocarps with axillary rhizoids Platydictya is peculiar in minute size of plants and non-differentiated epidermal cells.

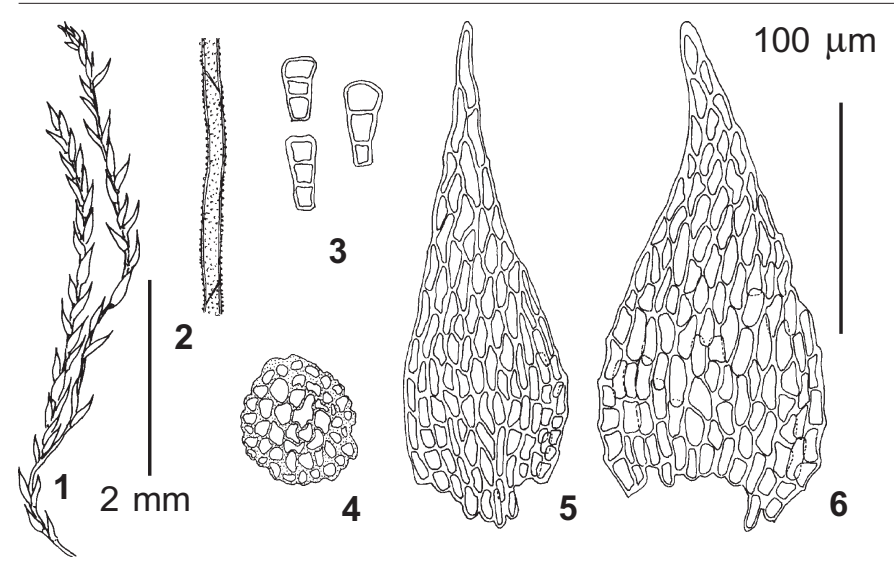

Fig. 14. Platydictya jungermannioides (Brid.) Crum (from Kukol $1800 \mathrm{~m} \mathrm{Ig-}$ natov 0/455): 1 - habit; 2 - portion of rhizoid; 3 - axillary gemmae; 4 stem cross-section; 5-6 - leaves. Scale bars: $2 \mathrm{~mm}$ - for $1 ; 100 \mu \mathrm{m}$ - for $2-6$. 
Platydictya jungermannioides (Brid.) Crum, Michigan Bot. 3: 60. 1964. - Hypnum jungermannioides Brid., Muscol. Recent. Suppl. 2: 255. 1812.

Fig. 14

Plants very small, in loose green to yellowgreen dull tufts or growing among other bryophytes. Stem ca. $1 \mathrm{~cm}$ long, loosely foliate, irregularly branched. Axillary hairs 2-celled, $35 \mu \mathrm{m}$ long, apical cell $30 \times 4.0 \mu \mathrm{m}$. Leaves straight, spreading, $0.2-0.3 \times 0.06-0.09 \mathrm{~mm}$, lanceolate to ovatelanceolate, acuminate; margins serrulate, especially near the base. Laminal cells rhombic, 15-25 ×6$7(5-6 / 1) \mu \mathrm{m}$. Alar cells in a small inconspicuous group. Gemmae in leaf axils 3-celled, 27-35 $\mu \mathrm{m}$ long, $7-8 \mu \mathrm{m}$ wide in the middle, $12-17 \mu \mathrm{m}$ wide in their distal clavate end.

Dioicous. Sporophytes not seen in Altai. Micrographs of the exostome was published by Ignatov \& Ochyra (1995): exostome teeth long, abruptly narrowed in the transition zone, entire above; in the lower part striolate, with \pm perfect, waved cristae; in the middle densely papillose; in the upper part with rare small papillae and prominent dorsal trabeculae.

Distribution: Platydictya jungermannioides occurs across the Holarctic in the Arctic and boreal zones, and in high mountains (in Central Asia, Caucasus, Yunnan, etc.). In Altai this species is infrequent at middle and upper elevations, on mesic soil banks and among rocks.

Specimens examined: Bogoyash Creek, upper course 2350 m (36/264); Kaitanak Creek 1500 m (A.Krylov \& Reczan 10.VII.1968 LE!); Kukol 1800 m (0/455); Tabozhok Peak $2250 \mathrm{~m}(31 / 163), 2750 \mathrm{~m}(31 / 164 ; 31 / 169 ; 31 / 317)$.
Myurella B. S. G.

The genus includes 4 species, growing in regions with cool climate, and is characterized by: (1) plants small, very fragile, julaceous; (2) leaves nearly round, strongly concave; (3) laminal cells short, papillose at back; (4) plants dioicous, with very rare sporophyte production; (5) capsule erect. Besides the normally developed imbricate shoots, all species produce stoloniferous shoots with rather remote leaves, which are different from "stem" leaves in (a) \pm appressed to the stem in their base and with spreading acumen; (b) \pm ovate to lanceolate and longer-acuminate; (c) laminal cells longer. No sporophytes were found in Altaian plants of Myurella; micrographs of exostome of all three species known in Altai were published by Ignatov \& Ochyra (1995).

This genus was placed for a long time in different families (Thuidiaceae, Theliaceae, Pterigynandraceae). Hedenäs (1987) suggested its relation to the Plagiotheciaceae, and Ignatov \& Ochyra (1995) provided additional evidence for a relationship to Platydictya.

\section{Key to THE ALTAiAn SPECIES OF MYURELLA}

1. Leaves rounded-obtuse, closely vermicularimbricate ............. M. julacea (p. 41)

1. Leaves acuminate, freely imbricate to spreading $\ldots \ldots \ldots \ldots \ldots \ldots \ldots \ldots \ldots \ldots \ldots \ldots \ldots$

2. Leaf margins serrulate; laminal cells with a low papilla in the upper corner on the dorsal surface .... M. tenerrima (p. 42)

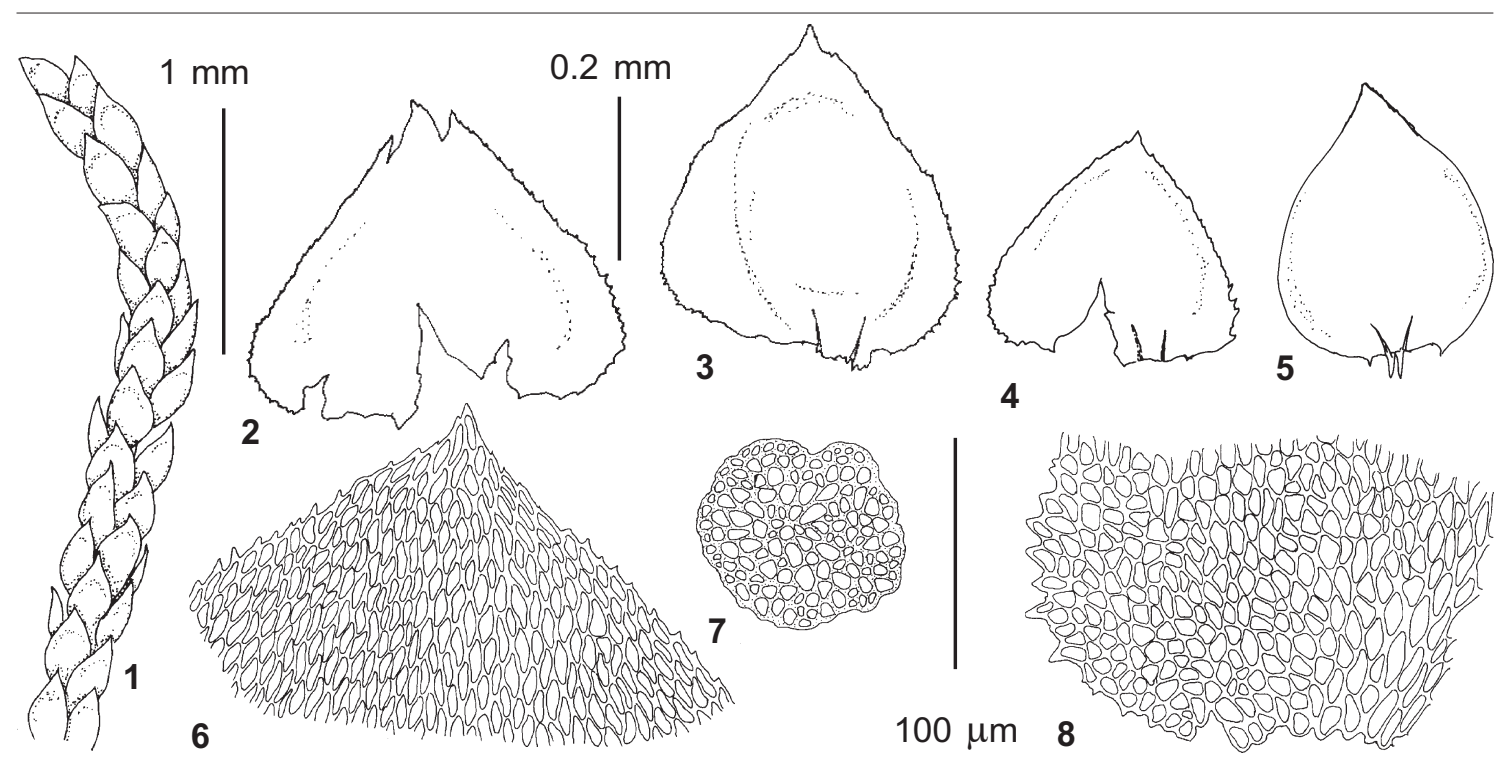

Fig. 15. Myurella julacea (Schwaegr.) B.S.G. (from Kukol $1750 \mathrm{~m}$ Ignatov 0/1048): 1 - habit; 2-5 - leaves; 6 - upper laminal cells; 7 - stem cross-section; 8 - alar cells. Scale bars: $1 \mathrm{~mm}-$ for $1 ; 0.2 \mathrm{~mm}$ - for 2-5; $100 \mu \mathrm{m}-$ for $6-8$. 


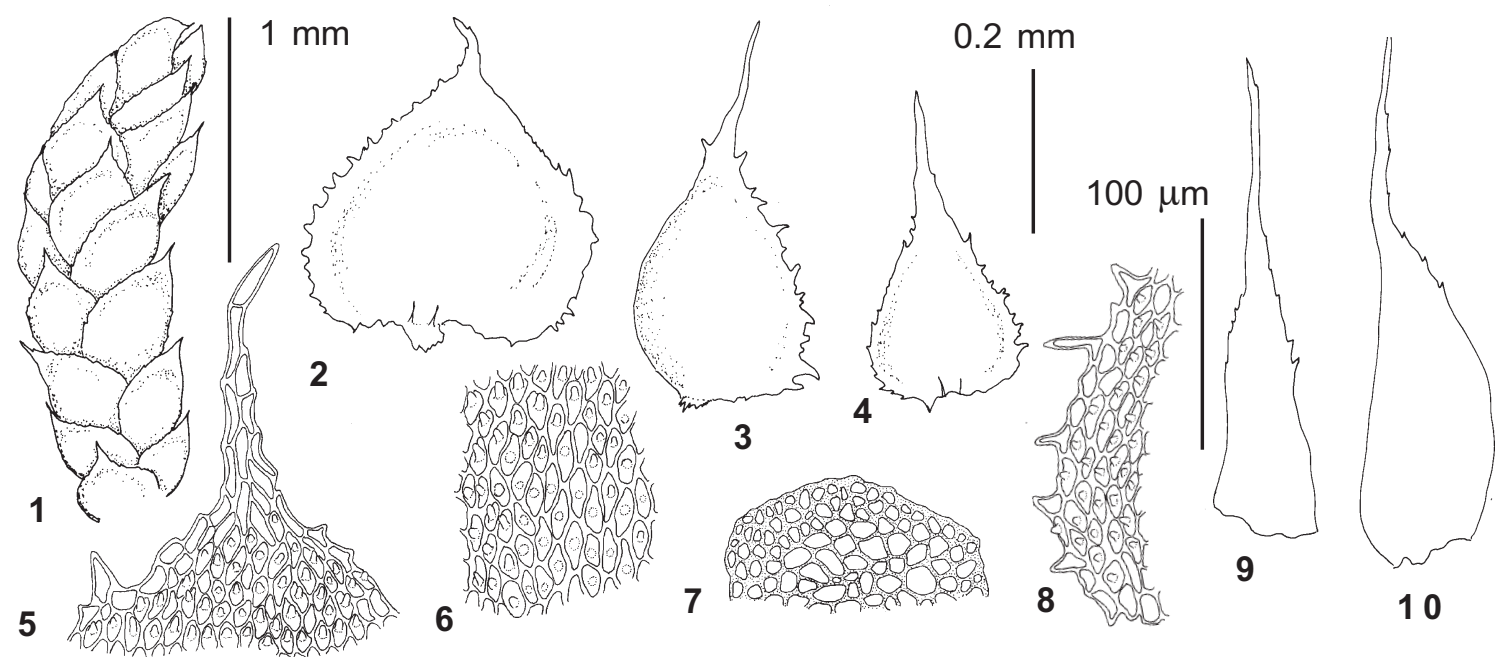

Fig. 16. Myurella sibirica (C. Muell.) Reim. (from Kairu Creek, 8 km upstream $1000 \mathrm{~m}$ Ignatov 15/14): 1 - habit; 2-4 - leaves; 5 upper laminal cells; 6 - middle laminal cells; 7 - stem cross-section; 8 - alar cells; 9-10 - perichaetial leaves. Scale bars: $1 \mathrm{~mm}$ - for $1 ; 0.2 \mathrm{~mm}$ - for $2-4,9-10 ; 100 \mu \mathrm{m}-$ for $5-8$.

2. Leaf margins ciliate-dentate; laminal cells with a high central papilla on the dorsal surface ............ M. sibirica (p. 41)

Myurella julacea (Schwaegr.) B.S.G., Bryol. Eur. 6: 41. 1853. - Leskea julacea Schwaegr. in Schultes, Reise Glockner 2: 363. 1804.

Fig. 15

Plants small, in pure whitish-green to glaucous tufts or often growing among other mosses. Stem vermicular-imbricate, usually $1 \mathrm{~cm}$ long, rarely irregularly branched. Axillary hairs 4-celled, 100-110 $\mu \mathrm{m}$ long, apical cell $35 \times 4 \mu \mathrm{m}$. Leaves $0.3-0.4 \times 0.3-$ $0.4 \mathrm{~mm}$, broadly-ovate to orbicular, obtuse, strongly narrowed toward insertion, very concave, ecostate; margin serrulate. Laminal cells 10-17 × $7(5 / 2) \mu \mathrm{m}$, with an obtuse papilla in the upper corner; marginal cells with thinner walls, forming a distinct border 2 cells wide; alar cells not differentiated. Dioicous. No sporophytes have been found in Altai or neighboring regions. Perichaetia numerous.

Distribution: Myurella julacea is widespread throughout cool regions of the Holarctic, and also in the Southern Hemisphere in Argentina and Antarctic islands (for worldwide map see Ochyra \& Szmajda, 1990). It is common in the Arctic and mountain regions, but absent or very rare in lowlands where there are no rock outcrops. This is a very common species throughout the Altai, in both wet and dry habitats, mostly on rocks.

Specimens examined: Bayas Lake $1850 \mathrm{~m}$ (0/1050); Berekhtuyaryk 1600 m (0/1134); Bogoyash Creek, upper course $2350 \mathrm{~m}$ (36/87), $2400 \mathrm{~m}(36 / 51), 2450 \mathrm{~m}(36 / 82)$; Chulcha River, in middle course 1100 m (9/84); Kairu Creek, 8 km upstream 1000 m (15/28); Kairu-Bazhi Peak 1700 m
(13/90), $2100 \mathrm{~m}(13 / 164 ; 13 / 53 ; 13 / 72 ; 13 / 87), 2300 \mathrm{~m}$ (13/137); Karagai 500 m (Zolotukhin 10.VIII.1988); Karakol Lakes 1900 m (26/127); Kayakkatuyarykskij Creek 2000 m (8/155), 2150 m (7/119); Kobiguayuk Creek 2100 m (0/1051), 2300 m (0/320); Kokorya Creek 2400 m (32/ 10; 32/9); Kukol 1750 m (0/1048; 0/1049), 1800 m (0/ 1047; 0/1128; 0/667); Maima $350 \mathrm{~m}$ (35/5); Tabozhok Peak 2150 m (31/32), 2250 m (31/30), 2300 m (31/28; $31 / 33), 2350 \mathrm{~m}(31 / 25), 2550 \mathrm{~m}(31 / 24 ; 31 / 27), 2700 \mathrm{~m}$ (31/31), $2750 \mathrm{~m}(31 / 29), 2800 \mathrm{~m}(31 / 26)$.

Myurella sibirica (C. Müll.) Reim., Hedwigia 76: 292. 1937. - Hypnum sibiricum C. Müll., Syn. Musc. Frond. 2: 418. 1851. Fig.16

Plants small, light-green. Stem julaceous, to $1 \mathrm{~cm}$ long, rarely irregularly branched. Leaves $0.3-0.4 \times$ 0.3-0.6 mm, broadly-ovate to orbicular, shortly acuminate, strongly narrowed toward insertion, strongly concave, ecostate; margins ciliato-dentate. Laminal cells $12-22 \times 8-10(6-8 / 1.5-2) \mu \mathrm{m}$, with one high central papilla. Dioicous. No sporophytes have been found in Altai or neighboring regions.

Distribution: Myurella sibirica is widespread in mountain regions of South Siberia, China, Japan, and Himalayas, and less widespread in Europe. Compared to M. tenerrima this is a more southern species, very rare in the Arctic and occurring in lower belts of mountains. In Altai it grows on wet soil and rocks, mostly at lower elevations.

Specimens examined: Bolshoi Shaltan Creek $550 \mathrm{~m}$ (0/1129; 0/1130); Derbogach $450 \mathrm{~m}$ (0/17;0/26); Ezhon Cape 440 m (Schischkin 10.IX.1931 LE!); Kairu Creek, 8 km upstream $1000 \mathrm{~m}$ (15/125; 15/14; 15/82); Kairu-Bazhi Peak 2100 m (13/71); Kamga Creek, 12 km upstream $550 \mathrm{~m}$ (0/106); Kamga Creek, upper course 830 $\mathrm{m}$ (Zolotukhin 7.VI.1991); Karagai $450 \mathrm{~m}$ (Zolotukhin 11.VIII.1988), 500 m (Zolotukhin 10.VIII.1988); Kishte 


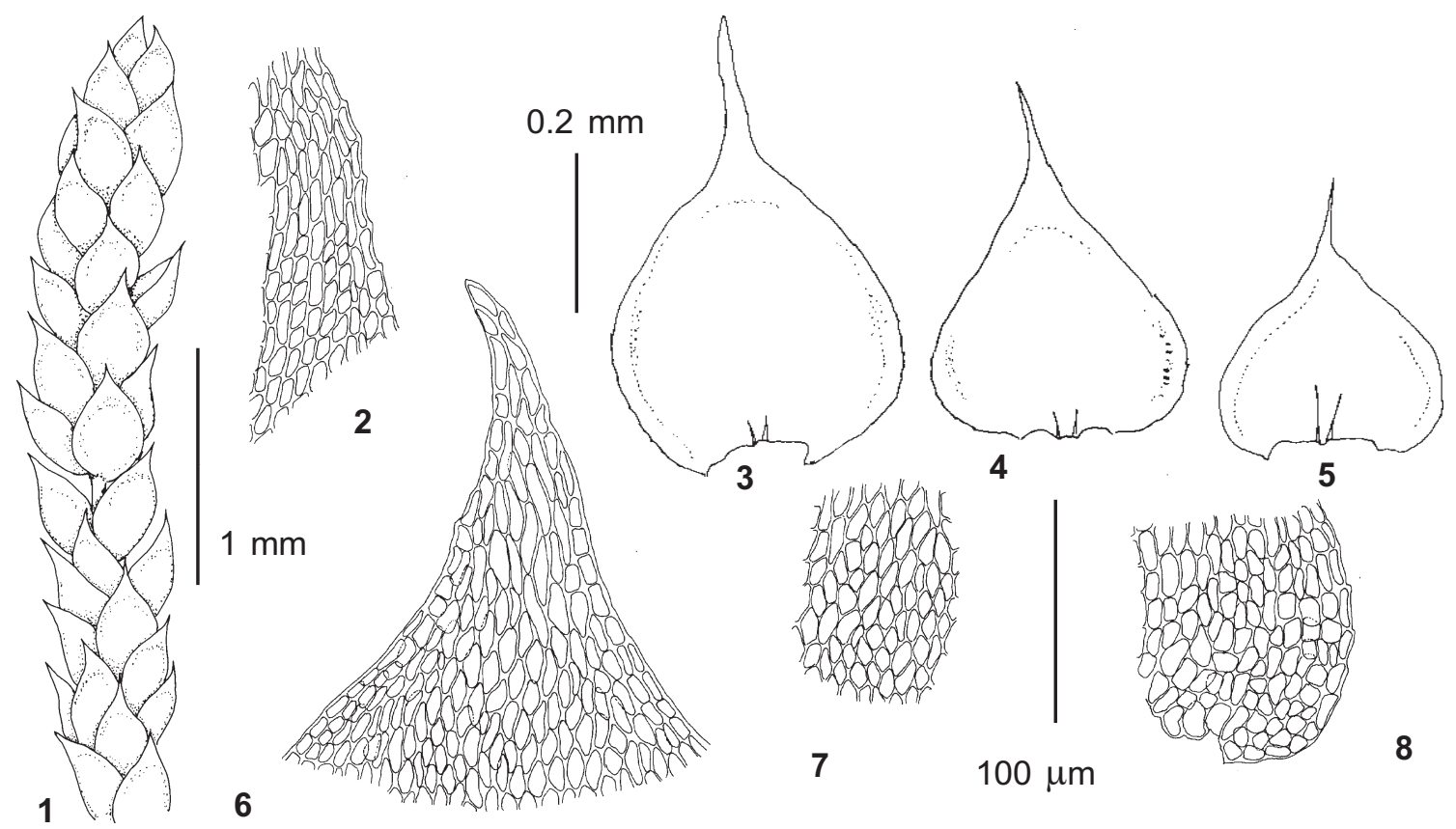

Fig. 17. Myurella tenerrima (Brid.) Lindb. (from Bayas Lake $1750 \mathrm{~m}$ Ignatov 0/1133): 1 - habit; 2 - middle laminal cells at leaf margin; 3-5 - leaves; 6 - upper laminal cells; 7 - middle laminal cells; 8 - alar cells. Scale bars: $1 \mathrm{~mm}$ - for $1 ; 0.2 \mathrm{~mm}$ - for $3-5 ; 100 \mu \mathrm{m}$ - for $2,6-8$.

$440 \mathrm{~m}$ (Zolotukhin 11.VII.1988); Korbu $440 \mathrm{~m}$ (Zolotukhin 15.VII.1988); Kukol $1800 \mathrm{~m}(0 / 1131), 1900 \mathrm{~m}$ (0/1132); Maloye Istyube Creek, $1 \mathrm{~km}$ upstream $600 \mathrm{~m}$ (Zolotukhin 19.V.1977); Ok-Porok Creek, $1.5 \mathrm{~km}$ upstream $470 \mathrm{~m}(2 / 47)$.

Myurella tenerrima (Brid.) Lindb., Musci Scand. 37. 1879. - Pterigynandrum tenerrimum Brid., Muscol. Recent. Suppl. 4: 132. 1819[1818].

Fig. 17

Plants small, pale-green. Stem julaceous, to $1 \mathrm{~cm}$ long, rarely irregularly branched. Leaves $0.3-0.6 \times$ 0.3-0.4 mm, broadly-ovate to orbicular, abruptly shortly acuminate, strongly narrowed toward insertion, strongly concave, ecostate; margins serrulate. Laminal cells 11-18(-23) × 7-9 (5-7/2) $\mu \mathrm{m}$, rhombic, with a papilla in the upper corner. Alar cells not differentiated. Dioicous. No sporophytes have been found in Altai or neighboring regions.

Usually Myurella sibirica and M. tenerrima are quite distinct, and occur in different zones. However, sometimes poorly developed forms of Myurella sibirica do not have especially long teeth on the leaf margins and may be confused with $M$. tenerrima. The most useful character to identify $M$. sibirica seems be the central position of papillae on laminal cells.

Distribution: Myurella tenerrima is principally an Arctic species, occurring in the alpine belt of some southern mountains (for worldwide map see Ochyra \& Szmajda, 1990). In Altai it is rare in the subalpine and alpine zones, on rocks and soil.
Specimens examined: Bayas Lake $1750 \mathrm{~m}(0 / 1133)$; Kairu Creek, upper course $1700 \mathrm{~m}$ (13/195; 13/91).

Orthothecium B. S. G.

This genus includes about 10 species, growing principally in cold and cool climates in the Northern Hemisphere.

Orthothecium was placed for a long time in the Entodontaceae or Hypnaceae. However, the peristome of Orthothecium is \pm perfect, with typical hypnoid teeth and endostome with high basal membrane. Therefore it has nothing to do with the former family. The combination of characters of species with axillary rhizoids suggests a closer relation to Plagiotheciaceae (Hedenäs, 1987) than to Hypnaceae. Within the group of genera with axillary rhizoids Orthothecium is peculiar in the stem with thick-walled epidermal cells; leaves \pm longly acuminate, truncate at base; laminal cells narrowly linear; often bronze to red color of plants. There is a general habit and size similarity between small-sized species of this genus, like O. strictum, and Isopterygiopsis. Large -sized species (O. rufescens (Brid.) B. S. G. and O. chryseum) have many apomorphic characters (robust plants, rigid and strongly plicate leaves). Besides axillary, rhizoides on abaxial side of leaf base occur in O. rufescens. 

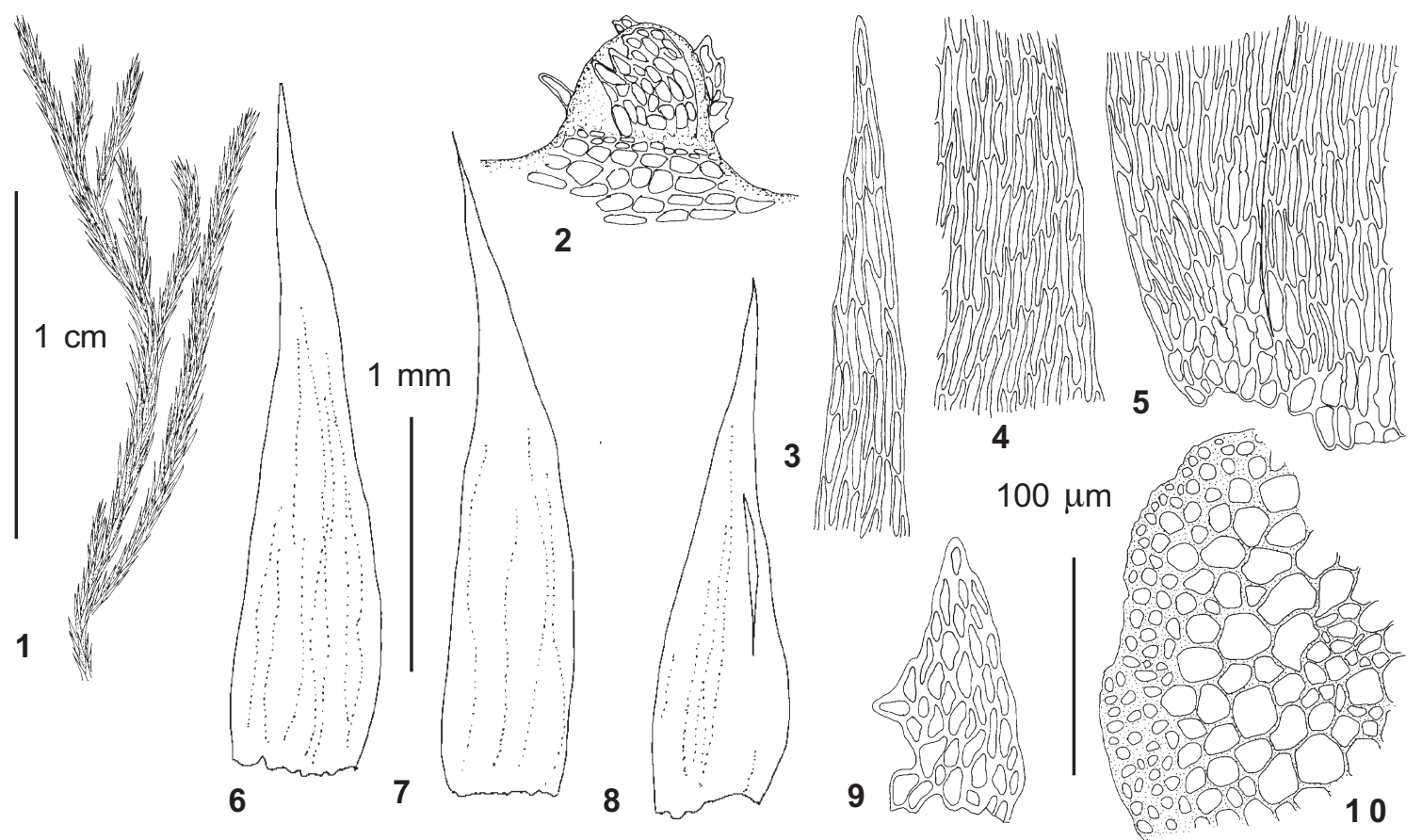

Fig. 18. Orthothecium chryseum (Schwaegr.) B.S.G. (from Tabozhok Peak $2700 \mathrm{~m}$ Ignatov $31 / 95$ ): 1 - habit; 2 branch initial with proximal branch leaves; 3 - upper laminal cells; 4 - middle laminal cells; 5 - alar cells; 6-8 - leaves; 9 - proximal branch leaf; 10 - stem cross-section. Scale bars: $1 \mathrm{~cm}-$ for $1 ; 1 \mathrm{~mm}$ - for $6-8 ; 100 \mu \mathrm{m}-$ for $2,3-5,9-10$.

Orthothecium has been considered to have pseudoparaphyllia (Hedenäs, 1987); however this character seems open to interpretation. The youngest branch initials are covered by incised lanceolate to triangular leaf-like structures. Afterward, the proximal branch somewhat elongates, so all these structures appear above the leafless narrowed zone with no foliose structures below the ring of small cells at branch base (Fig. 18-2). This situation seems more similar to those observed in Isopterygiopsis and Myurella. So we interpret these leaf-like structures as juvenile leaves and pseudoparaphyllia therefore are lacking.

\section{KEY TO THE ALTAiAn SPECiES OF ORTHOTHECIUM}

1. Robust plants, with strongly plicate leaves ................. O. chryseum (p. 43)

1. Rather small plants, with non-plicate leaves ............................... 2.

2. Leaves long-acuminate, with plane margins ......... O. intricatum (p. 45)

2. Leaves short-acuminate, with recurved margins ......... O. strictum (p. 45)
Orthothecium chryseum (Schwaegr.) B.S.G., Bryol. Eur. 5: 107. 1851. - Hypnum chryseum Schwaegr. in Schultes, Reise Glockner 2: 364. 1804.

Fig. 18

Plants rather robust, in \pm soft reddish-golden shiny tufts. Stem ascending to erect, $6 \mathrm{~cm}$ long, without hyalodermis, with central strand, rarely branched; young branches departing from the stem at acute angle and often then \pm parallel to the stem. Axillary hairs 3-4-celled, 77-100 $\mu \mathrm{m}$ long, apical cell 30-50 × 4 $\mu \mathrm{m}$. Leaves straight, \pm appressed, $2.8 \times 1.0 \mathrm{~mm}$, broadly lanceolate, deeply plicate; margins entire and incurved nearly throughout. Laminal cells 60-90 × 5-7 $(1.5-3 / 3-5) \mu \mathrm{m}$, with very thick walls. Basal cells usually colored, shorter; alar groups of subquadrate cells small and indistinct. Dioicous. Sporophytes unknown in Altai or neighboring regions.

According to numerous literature records, $O$. rufescens is rather common in the Asian Arctic (Afonina \& Czernyadjeva, 1995) and it has been reported by Bardunov (1974) in the Sayan and Altai mountains in South Siberia. However we found all so-named collections from Asian Russia to be in fact O. chryseum. The latter species is very polymorphic in Altai and represented mostly by forms with long, gradually tapering leaves. However (1) there are numer- 
Table 1. Differences between Orthothecium chryseum and O. rufescens

\begin{tabular}{|c|c|c|}
\hline & O. chryseum & O. rufescens \\
\hline plant color & bronze- or golden-reddish & brownish- or purplish-red \\
\hline leaves when dry & $\begin{array}{l}\text { appressed on most parts of the stem, } \\
\text { spreading in uppermost part of stem }\end{array}$ & $\begin{array}{l}\text { spreading along practically all } \\
\text { the stem length }\end{array}$ \\
\hline leaf margins at base & $\begin{array}{l}\text { plane, although sometimes masked } \\
\text { by submarginal plicae }\end{array}$ & incurved \\
\hline alar cells & \pm differentiated & non differentiated \\
\hline median laminal cells & mostly shorter than $100 \mu \mathrm{m}$ long & mostly $110-150 \mu \mathrm{m}$ long \\
\hline
\end{tabular}

ous transitions to the typical, shortly pointed form which could be found in any extensive collections; (2) leaves of proximal shoot are constantly short-acuminate, though distal leaves became often long-acuminate. So though the leaf shape is widely used in keys, it has a restricted taxonomic value. The descriptions of plant color, as golden in O. chryseum, reddish in O. rufescens, are also misleading, since O. chryseum in sunny places is usually red. The more stable characters are summarized in table 1 .

We have seen specimens of $O$. rufescens from Central Europe, Scandinavia and Japan.

Distribution: Orthothecium chryseum has a wide distribution in the Arctic (including northernmost very severe regions) and high mountains of Europe, Siberia, Central Asia and North America. In Altai it grows in wet open tundras in southeastern Altai,

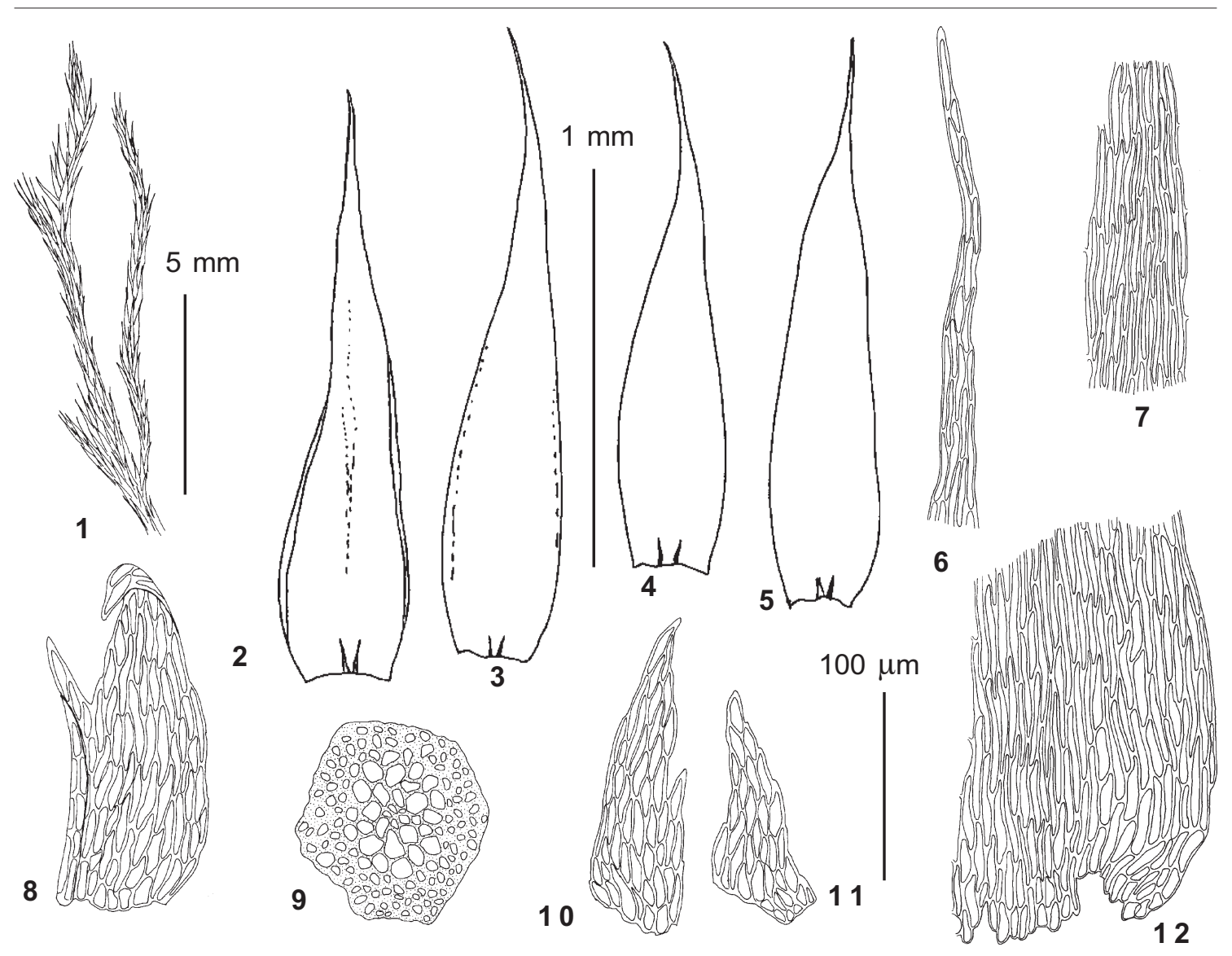

Fig. 19. Orthothecium intricatum (Hartm.) B.S.G. (from Karakol Lakes 1950 m Ignatov 28/80): 1 - habit; 2-5 leaves; 6 - upper laminal cells; 7 - middle laminal cells; 8, 10-11 - proximal branch leaves; 9 - stem cross-section; 12 - alar cells. Scale bars: $5 \mathrm{~mm}$ - for $1 ; 1 \mathrm{~mm}$ - for $2-5 ; 100 \mu \mathrm{m}$ - for $6-12$. 

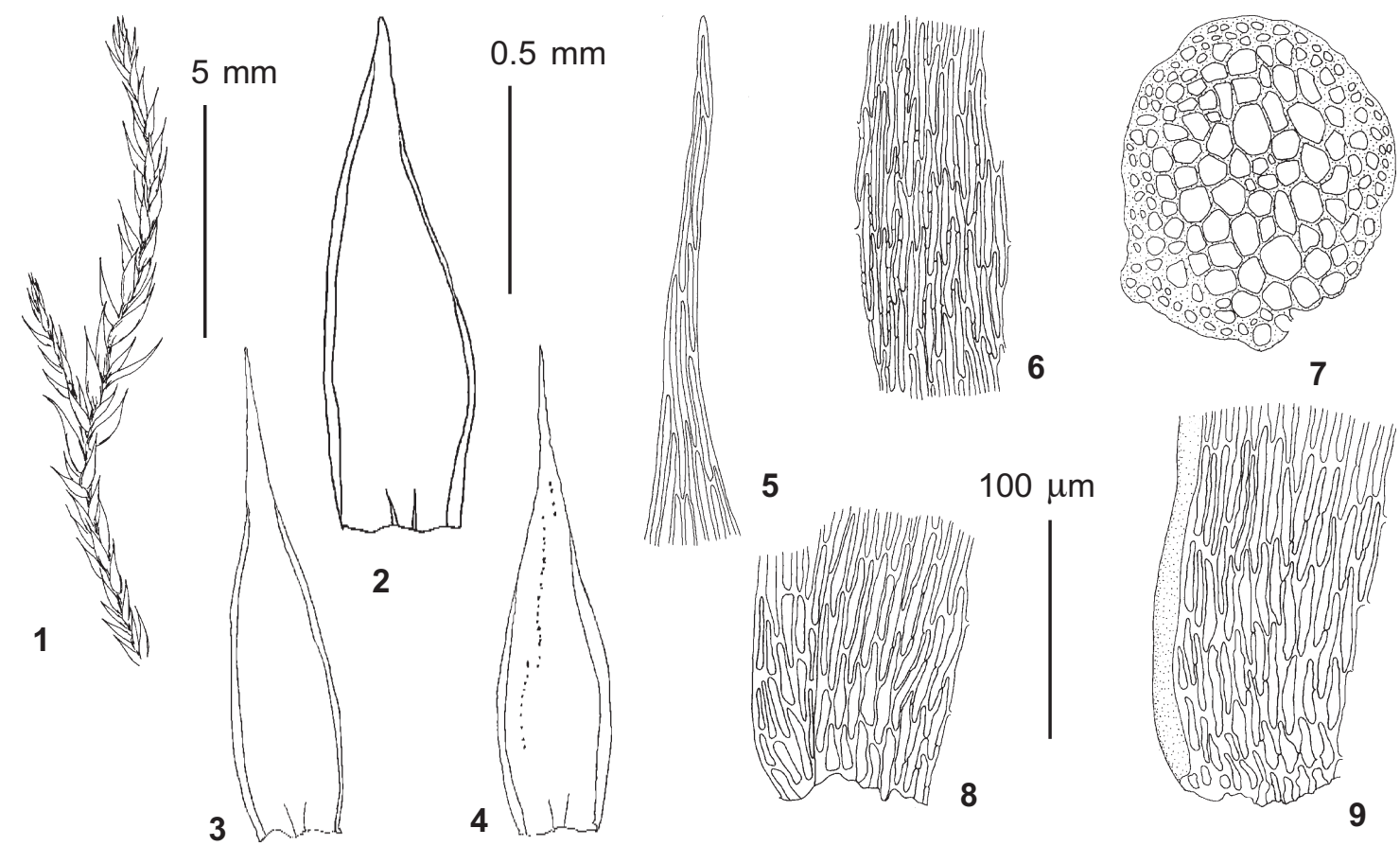

6
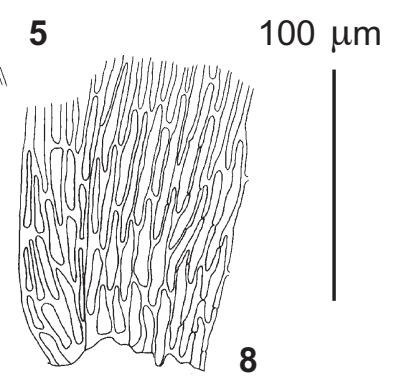

7

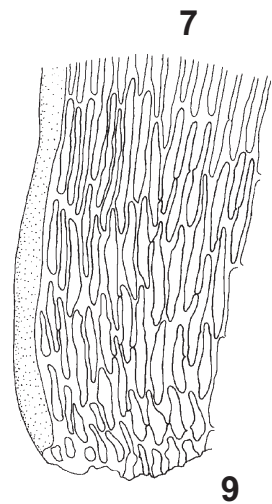

Fig. 20. Orthothecium strictum Lor. (from Kukol 1800 m Ignatov 0/1020): 1 - habit; 2-4 - leaves; 5 - upper laminal cells; 6 - middle laminal cells; 7 - stem cross-section; 8-9 - alar cells. Scale bars: $5 \mathrm{~mm}-$ for $1 ; 0.5 \mathrm{~mm}-$ for $2-4 ; 100 \mu \mathrm{m}$ - for $5-9$.

rarer in alpine regions of other parts of Altai. The second type of habitat of this species is the moist "dri pping" cliffs, where it grows at all elevations.

Specimens examined: Bogoyash Creek, upper course $2350 \mathrm{~m}$ (0/2047; 36/197; 36/218), $2400 \mathrm{~m}(36 / 254) ;$ Bolshoi Shaltan Creek 540 m (Zolotukhin 7.VI.1989), $560 \mathrm{~m}(0 / 1019 ; 0 / 641)$; Bolshoye Istyube Creek 470 m (Zolotukhin 5.VII.1988; 18/ 119); Kairu-Bazhi Peak 1700 m (13/193), 2100 m (13/39); Karakol Lakes 1950 m (28/99); Kukol 1850 m (0/1018); Tabozhok Peak $2350 \mathrm{~m}$ (31/91), $2450 \mathrm{~m}$ (31/88), $2700 \mathrm{~m}$ (31 94; 31/95), $2750 \mathrm{~m}$ (31/89; 31/92), $2800 \mathrm{~m}(31 / 90 ; 31 / 93)$.

Orthothecium intricatum (Hartm.) B.S.G., Bryol. Eur. 5: 108. 457. 1851. - Leskea intricata Hartm., Handb. Skand. Fl., ed. 5, 336. 1849.

Fig. 19

Plants rather small in \pm glossy, green to reddishgolden tufts. Stem 1.0-1.5 cm long in upper leafy part, with central strand, rarely branched. Axillary hairs 3-celled, $70 \mu \mathrm{m}$ long, apical cell $30 \times 4 \mu \mathrm{m}$. Leaves erect, $1.5-1.8 \times 0.3-0.4 \mathrm{~mm}$, lanceolate, longly acuminate; margins entire, recurved at places. Laminal cells 50-70 $\times 6(4 / 2) \mu \mathrm{m}$. Alar cells not differentiated. Dioicous. Sporophytes are unknown in Altai or neighboring regions.

Distribution: Orthothecium intricatum occurs mostly in mountains of boreal to temperate zone, with only few localities in the Arctic. It is known in mountains of Europe and northern Africa, Caucasus, Crimea, Middle Asia, Tibet, Himalayas, and Japan. In
Altai it was found on moist rocks in the forest to subalpine zones.

Specimens examined: Derbogach 440 m (0/1021); Kamga Creek, 10 km upstream 560 m (0/1022); Karakol Lakes $1950 \mathrm{~m}(28 / 80)$.

Orthothecium strictum Lor., Moosstudien, 122. f. 5d. 1864.

Fig. 20

Plants very variable, from medium-sized extensive mats with \pm prostrate stems ca. $2.5 \mathrm{~cm}$ long to small dense tufts with stems less than $1 \mathrm{~cm}, \pm$ glossy, green to reddish-golden. Stem rarely branched, with central strand. Axillary hairs 3-4-celled, 80-100 $\mu \mathrm{m}$ long, apical cell 30-40 $\times 4 \mu \mathrm{m}$. Leaves erect to tightly appressed (in smaller forms), $1.0-1.3 \times 0.3 \mathrm{~mm}$, lanceolate, shortly acuminate; margins entire, recurved at places or nearly throughout (in smaller forms). Laminal cells $(40-) 50-85 \times 6(4 / 2) \mu \mathrm{m}$. Alar cells not differentiated. Dioicous. Sporophytes unknown in Altai or neighboring regions.

Orthothecium strictum is polymorphic in Altai. Alpine forms are very small and have densely imbricate leaves, while plants from more sheltered places and from lower altitudes are much larger and have erect-spreading leaves. This variability is easy to interpret as an environmental response.

Distribution: This is mostly an Arctic species, rarely found in mountains of northern Europe, Urals 

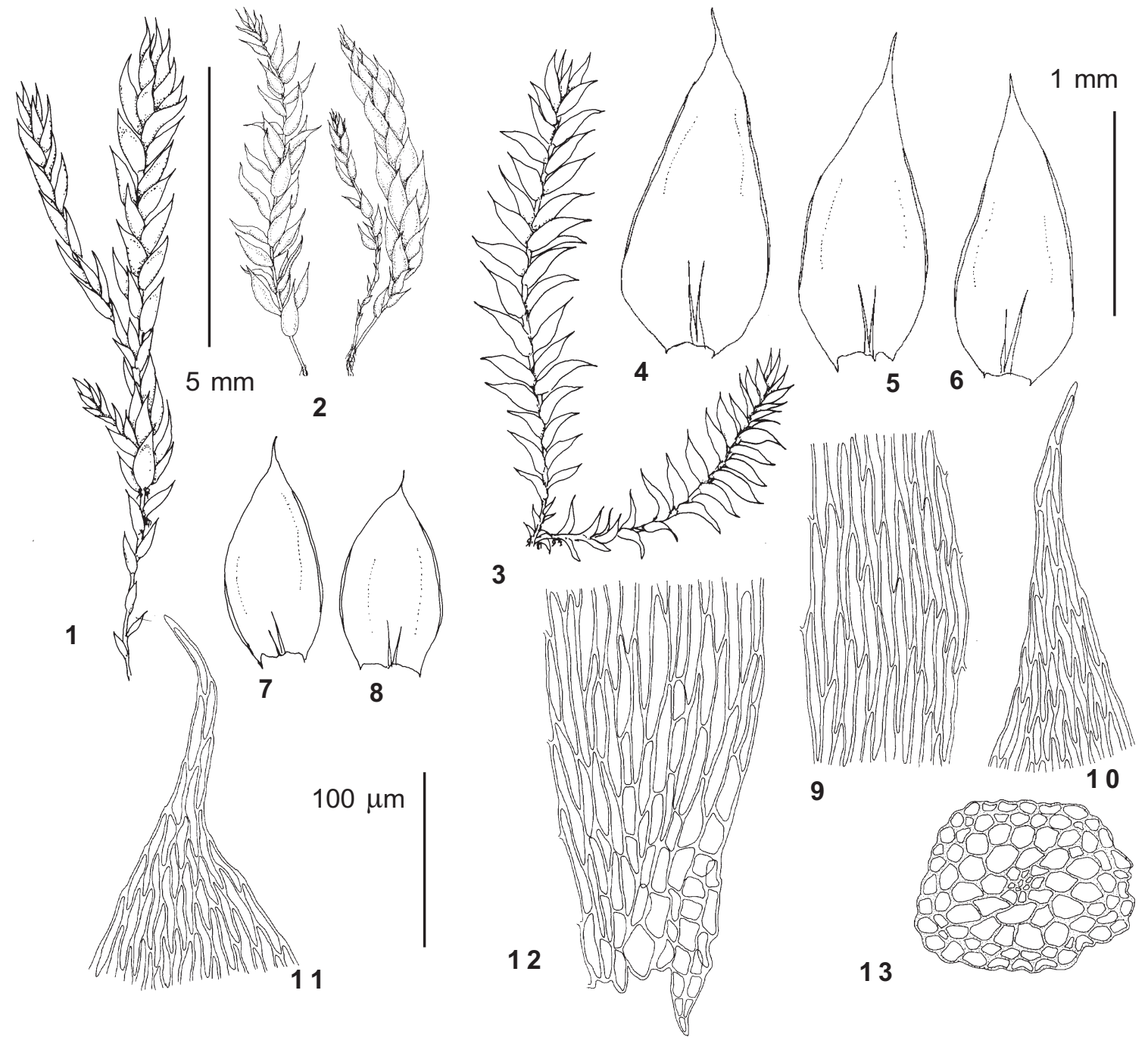

Fig. 21. Plagiothecium cavifolium (Brid.) Iwats. ("cavifolium-phenotype”: 1-2, 7-13 - from Yailyu $460 \mathrm{~m}$ Ignatov 0/1242; "succilentum-phenotype": 3-6 - from Kobukhta 700 m Ignatov 0/248): 1-3 - habit; 4-8 - leaves; 9 - middle laminal cells; 10-11 - upper laminal cells; 12 - alar cells; 13 - stem cross-section. Scale bars: $5 \mathrm{~mm}-$ for $1-3$; $1 \mathrm{~mm}$ - for $4-8 ; 100 \mu \mathrm{m}$ - for $9-13$.

(southward to about $60^{\circ} \mathrm{N}$ ), and Siberia. In Altai Orthothecium strictum grows on soil and rocks, mostly above the tree line, with only one locality in the upper forest zone.

Specimens examined: Ak-Turu Creek, upper course 2800 m (Bardunov 19.VII.1966 IRK!); Bogoyash Creek, upper course

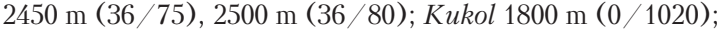
Tabozhok Peak 2700 m (31/319), 2750 m (31/183; 31/96); Tokpak Creek, in middle course $2050 \mathrm{~m}(36 / 42)$.

Plagiothecium B. S. G.

Plagiothecium includes about 30 species, distributed in cold, boreal and temperate zones of both hemispheres. It is a well-delimited genus, characterized by: (1) stem with thin-walled epidermal cells; (2) tendency to complanate foliage and asymmetric leaves; (3) decurrent leaves; (4) rhizoids mostly abaxial on leaves, often on costa.

The segregation from Plagiothecium is possible for $P$. latebricola, into the monotypic genus Philoscia Berk., Handb. Brit. Moss. 146. 1863. This species has an isolated position due to (1) reduction of endostome, which lacks cilia, and has low basal membrane; (2) exostome teeth with longitudinal cristae in the middle and longitudinal striolation above the transition zone; ventral trabeculae smooth; (3) spore release in winter, not in summer, as in all other species at least in our territory; (4) gemmae on leaf tips and in leaf axils, but not abaxial on leaves. 

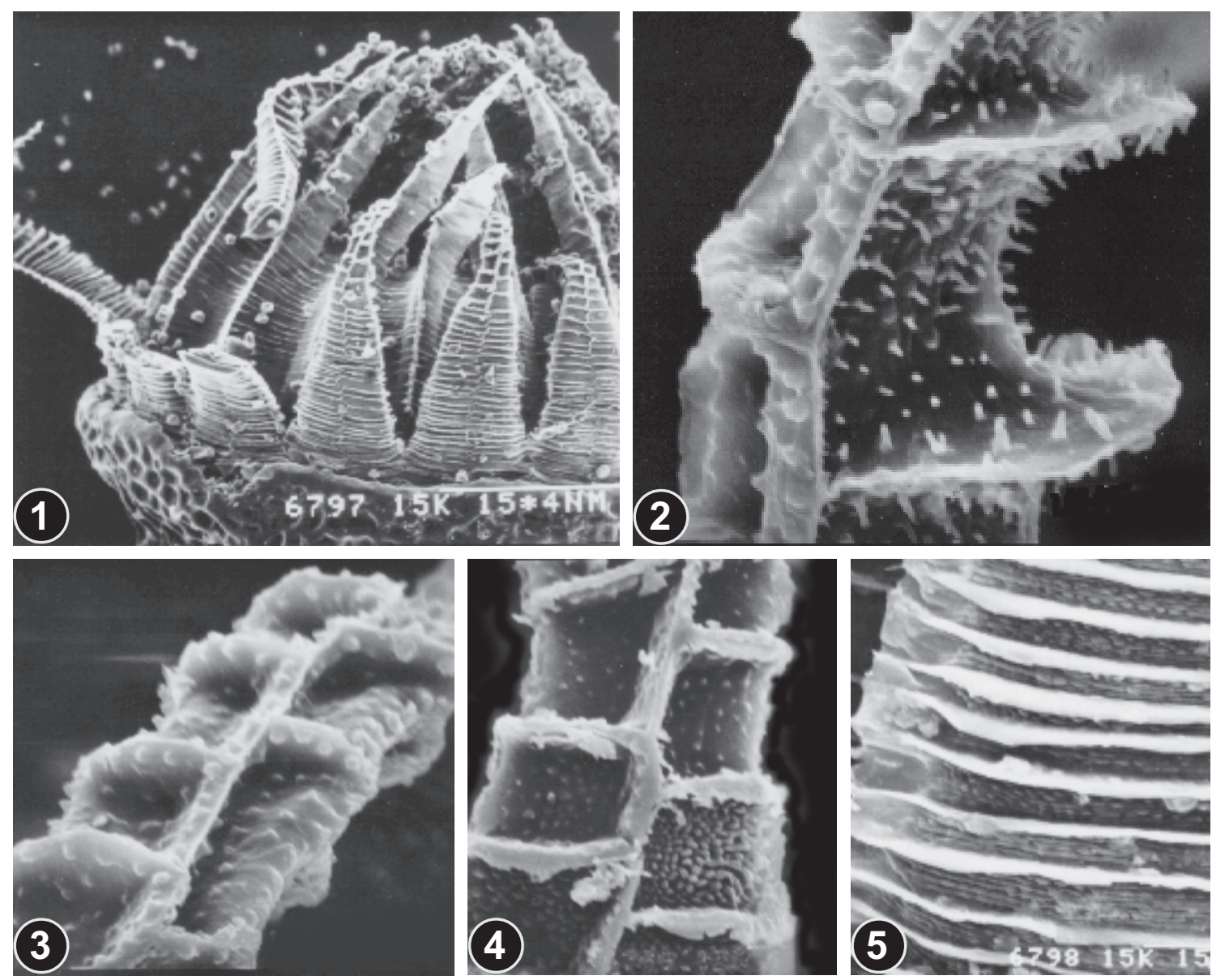

Fig. 22. Plagiothecium cavifolium (Brid.) Iwats. (from Ukraine, Lvov Province, Ignatov 14.IX.1991, MHA): 1 peristome $(220 \times) ; 2-$ side view of exostome tooth in upper part, showing papillose inner trabeculae $(3800 \times)$; $3-$ outer surface of exostome tooth in upper part $(2800 \times)$; 4 - outer surface of exostome tooth in transition zone $(1900 \times)$; 5 outer surface of exostome tooth in lower part $(1900 \times)$.

Plagiotheciella Fleisch. ex Broth., nom. illeg., was suggested to segregate $P$. latebricola and also $P$. piliferum (and $P$. passaiensis (Aust.) Fleisch., which appears to be Isopterygiopsis pulchella). However the close relation of $P$. piliferum and $P$. latebricola seems doubtful: among the above listed peculiarities of the latter species only the low basal membrane is observed in $P$. piliferum. Also in this species the outer surface of exostome is totally papillose (unlike other Altaian species of the genus).

\section{KEY TO THE ALTAiAN SPECIES OF PLAGIOTHECIUM}

1. Plants clearly complanate; leaves asymmet-

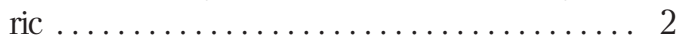

1. Plants not or indistinctly complanate; leaves \pm symmetric . ................. 3
2. Leaf decurrencies broad, 3-5 cells wide, composed of \pm isodiametric cells; laminal cells (10-)13-18 $\mu \mathrm{m}$ wide (at $1 / 3$ of leaf length); capsule curved ............. P. denticulatum (p. 50)

2. Leaf decurrencies narrow, 2-3 cells wide, composed of elongate cells; laminal cells 5-8 $\mu \mathrm{m}$ wide; capsule nearly straight

............. P. laetum (p. 51)

3. Plants small; leaf ti ps with gemmae (or otherwise at least with some leaves ti ps appearing eroded) ....... P. latebricola (p. 52)

3. Plants medium-sized; gemmae on abaxial leaf base, often absent; leaves concave; costa double or forked, usually prominent, extending $1 / 3-4 / 7$ the leaf length

................. P. cavifolium (p. 48) 


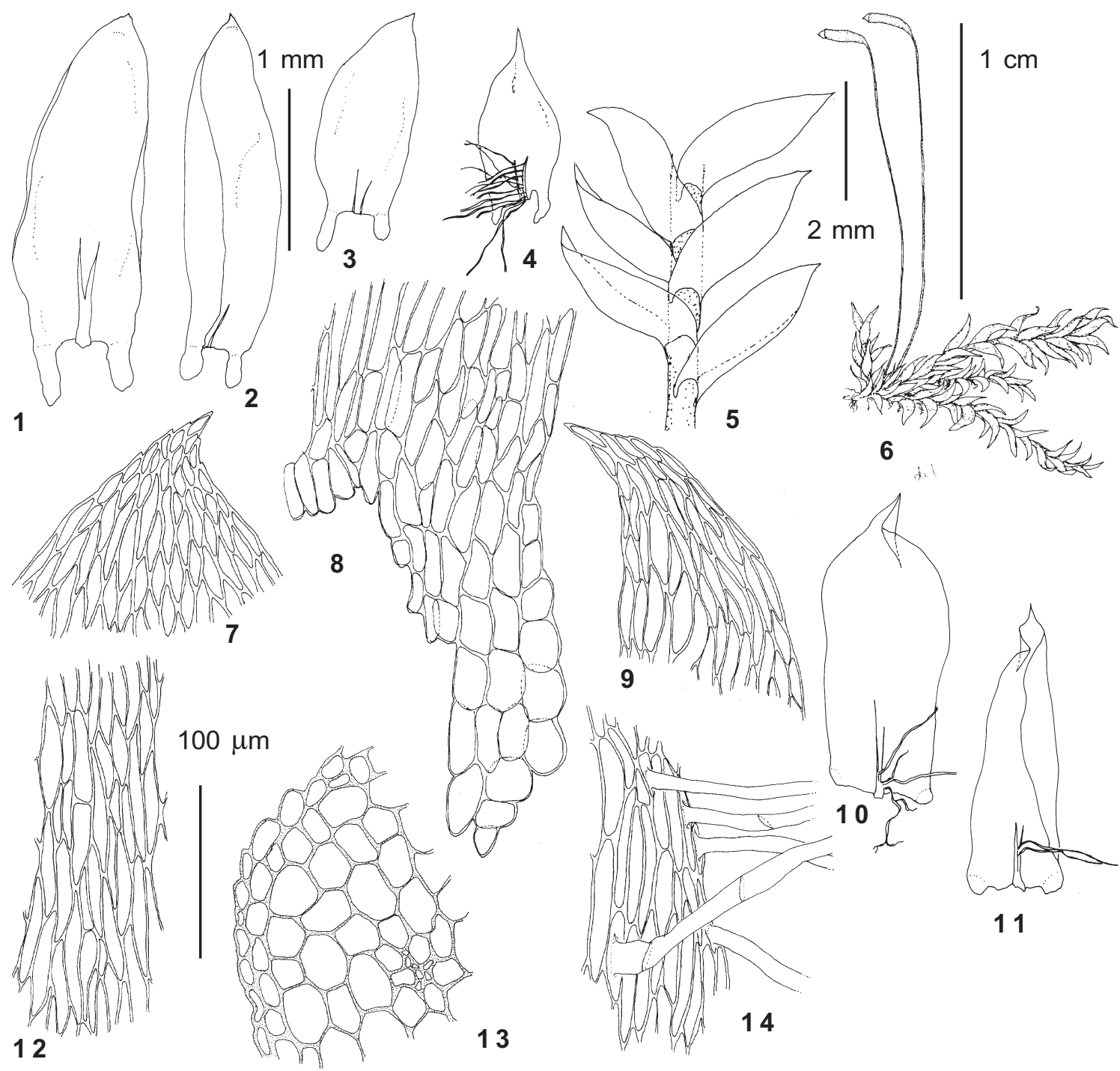

Fig. 23. Plagiothecium denticulatum (Hedw.) B.S.G. (from Kayakkatuyarykskij Creek 1940 m Ignatov 3/152): 14 - leaves; 5 - part of shoot; 6 - habit; 7, 9 - upper lamina cells of stem leaf; 8 - alar cells of stem leaf; 10-11 perichaetial leaves; 12 - middle laminall cells of stem leaf; 13 - stem cross-section; 14 - basal leaf cells with rhizoides. Scale bars: $1 \mathrm{~cm}$ - for $6 ; 2 \mathrm{~mm}$ - for $5 ; 1 \mathrm{~mm}$ - for $1-4,10-11 ; 100 \mu \mathrm{m}$ - for $7-9,12-14$.

Plagiothecium cavifolium (Brid.) Iwats., J. Hattori Bot. Lab. 33: 360. 1970. - Hypnum cavifolium Brid., Bryol. Univ. 2: 556 'cavifolius'. 1827.

Figs. $21 \& 22$

Plants medium-sized to rather robust, green to whitish-green, in dense to loose mats. Stem julaceous to complanate, to $2-3 \mathrm{~cm}$ long, with central strand. Axillar hairs 4-5-celled, 180-230 $\mu \mathrm{m}$ long; apical cell $50-70 \times 12-13 \mu \mathrm{m}$. Leaves 1.0-2.1 $\times 0.5-0.8 \mathrm{~mm}$, ovatelanceolate, symmetric, with \pm equal short decurrencies; costa double or sometimes single and forked, often long, to $1 / 2$ the leaf length; margins recurved at places. Laminal cells 80-160 × 8-16 (6-14/2) $\mu \mathrm{m}$; cells in decurrencies large, thin-walled.

Dioicous. Sporophytes unknown in Altai. SEM observation of the exostome teeth of a specimen from Ukrainian Carpatian Mts. (Igantov \# MHA) shows their similarity to $P$. denticulatum and $P$. laetum: teeth \pm abruptly narrowed in the transition zone, subentire above; in the lower part striolate, with waved cristae; in the middle densely papillose on few plates; in the upper part above with small low rare papillae, high and incrassate dorsal trabeculae, not incrassate margin; ventral surface and trabeculae sparsely spinulose.

Plagiothecium cavifolium is very variable in Altai, and most of its collections can be sort- 

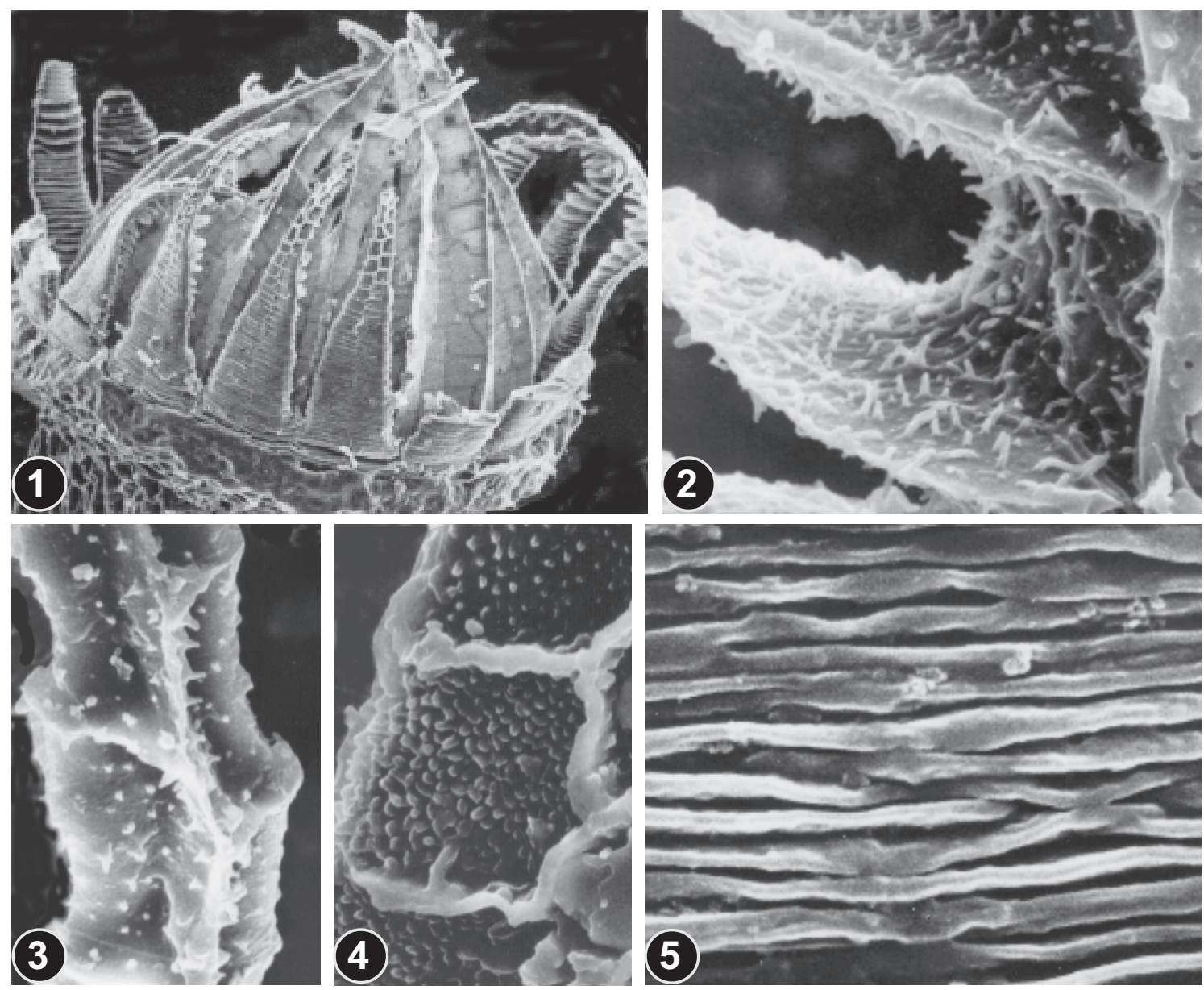

Fig. 24. Plagiothecium denticulatum (Hedw.) B.S.G. (from Kayakkatuyarykskij Creek 1940 m Ignatov 3/152): 1 - peristome $(200 \times) ; 2$ - side view of exostome tooth in upper part, showing papillose inner trabeculae $(4000 \times)$; $3-$ outer s urface of exostome tooth in upper part $(3000 \times) ; 4-$ outer surface of exostome tooth in transition zone $(3500 \times)$; 5 - outer surface of exostome tooth in lower part $(13000 \times)$.

ed into P. cavifolium s. str. (rather small, julaceous plants with very concave leaves, obtuse in general outline, but often with short reflexed tips) or P. succulentum (Wils.) Lindb. (medium-sized, \pm complanate form with gradually acuminate leaves). The latter grows in more shaded and wet habitats on soil or rotten wood, while the former occurs in crevices of \pm xeric rock outcrops. However in deep crevices of rocks and sometimes in other habitats there are intermediates which we were unable to sort to one of the two. Dimensions of leaves and laminal cells seem correlate with the habit, providing little help for delimitation of these forms.

Distribution: Widespread species, known from most European countries, most regions of the former USSR (from the high Arctic to mountains of Cauca- sus, Middle Asia, southern Far East) and further to Himalayas, China, and Japan. In North America it is equally common in many areas, reaching Georgia, Alabama, and Arkansas in the south. Also reported from Antarctic islands and Hawaii. In Altai P. cavifolium grows on rocks and soil at all the altitudes.

Specimens examined: (cavifolium-phenotype): Ayulyuyuzyuk Creek 2050 m (0/393), 2150 (0/130); Bayas Lake $1750 \mathrm{~m}(0 / 1241 ; 0 / 657)$; Bogoyash Creek, in middle course $2400 \mathrm{~m}(36 / 167)$; Kairu Creek, $16 \mathrm{~km}$ upstream $1400 \mathrm{~m}(14 / 53)$; Kamga Creek, $14 \mathrm{~km}$ upstream 660 m (0/1243); Kobiguayuk Creek 2350 m (0/1240); Saluru Creek, in middle course $2050 \mathrm{~m}$ (36/289); Yailyu $440 \mathrm{~m}(0 / 658 ; 0 / 659), 460 \mathrm{~m}(0 / 1242)$;

(succilentum-phenotype and intermediate forms): Kishte $440 \mathrm{~m}$ (Zolotukhin 11.VII.1988); Bolshoye Istyube Creek $470 \mathrm{~m}(0 / 1244 ; 18 / 18 \mathrm{a} ; 18 / 56)$; Chiri Creek, $0.5 \mathrm{~km}$ upstream $450 \mathrm{~m}$ (17/110); Karakem River, $3 \mathrm{~km}$ upstream $1600 \mathrm{~m}(0 / 1415)$; Chulcha River, in middle course 1100 m (9/75); Elekmonar Creek, 5 km upstream $700 \mathrm{~m}$ (26/ 


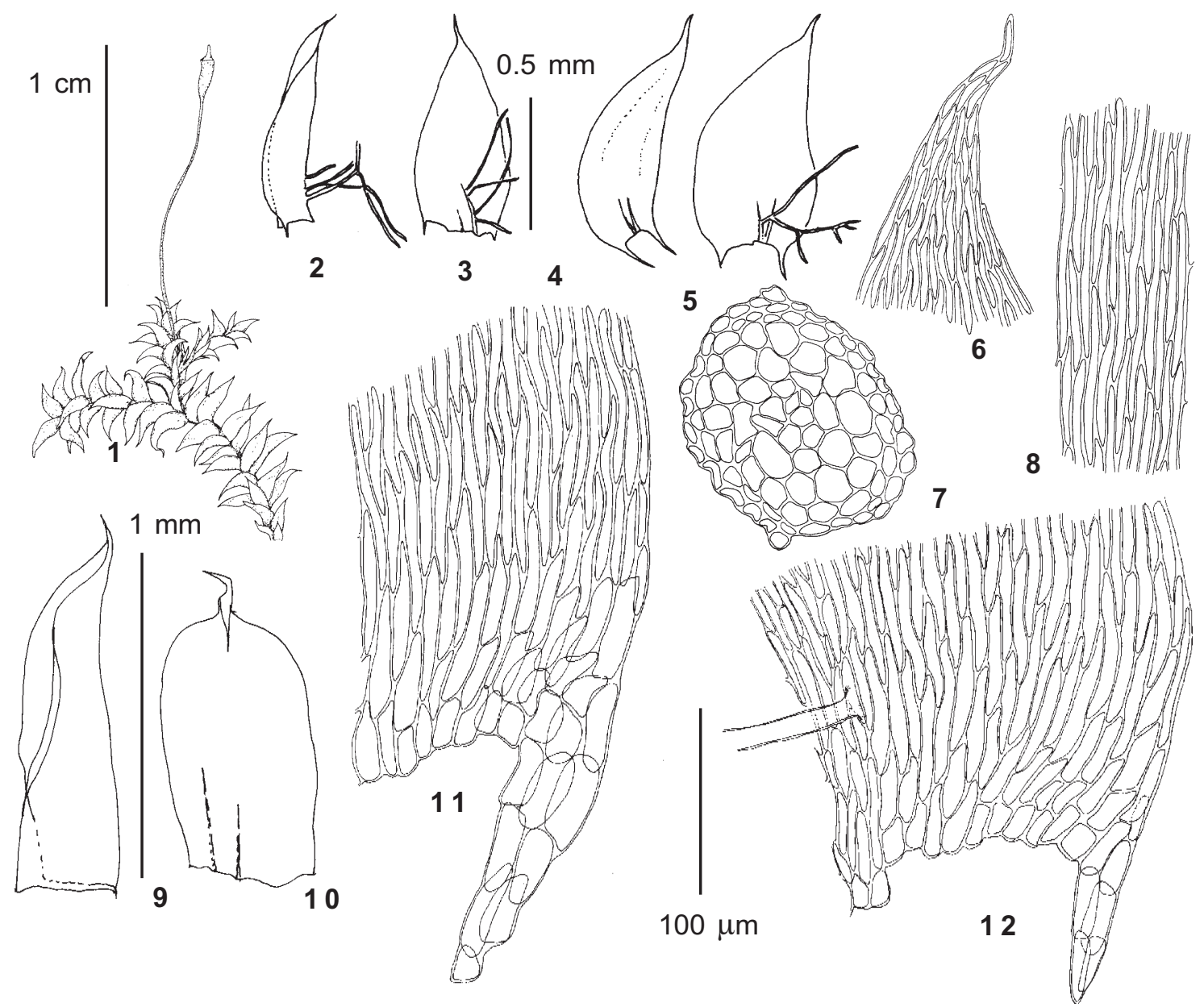

Fig. 25. Plagiothecium laetum B.S.G. (from Kamga Creek, 13 km upstream $630 \mathrm{~m}$ Ignatov 0/1042): 1 - habit; 25 - leaves; 6 - upper laminal cells; 7 - stem cross-section; 8 - middle laminal cells; 9-10 - perichaetial leaves; 1112 - alar cells. Scale bars: $1 \mathrm{~cm}-$ for $1 ; 1 \mathrm{~mm}-$ for $9-10 ; 0.5 \mathrm{~mm}-$ for $2-5 ; 100 \mu \mathrm{m}-$ for $6-8,11-12$.

42; $26 / 52) ;$ Kayakkatuyarykskij Creek $1760 \mathrm{~m}(8 / 13)$, $1950 \mathrm{~m}(8 / 302) ; 2050 \mathrm{~m}$ Kobukhta $700 \mathrm{~m}(0 / 248)$; Maloye Istyube Creek, 1 km upstream $700 \mathrm{~m}$ (Zolotukhin 22.VII.1991); (7/30); Tura Creek, in middle course 1300 $\mathrm{m}(28 / 36)$; Yurga $450 \mathrm{~m}(21 / 12)$.

Plagiothecium denticulatum (Hedw.) B.S.G., Bryol. Eur. 5: 190. 1851. - Hypnum denticulatum Hedw., Sp. Musc. 237. 1801. Figs. 23 \& 24.

Plants medium-sized, in green to dark-green slightly glossy mats. Stem irregularly branched, to 2 cm long, strongly complanate, with central strand; epidermal cells thin-walled, not enlarged. Axillary hair 4-5-celled, 200-270 $\mu \mathrm{m}$ long; apical cell 60-70 $\times$ $12-13 \mu \mathrm{m}$. Leaves spreading, $1.5-3 \times 0.9-1.1 \mathrm{~mm}$, ovate, asymmetric, with broad uneven decurrencies, the upper decurrency wider, 60-65 $\mu \mathrm{m}$ (3-5 cells) wide; costa double, to $1 / 3-1 / 2$ the leaf length; margins plane or recurved, entire or serrulate in the upper $1 /$ 5. Laminal cells $110-140 \times 13-18(12-17 / 1) \mu \mathrm{m}$. In the decurrencies cells $30-35 \times 17-25 \mu \mathrm{m}$.
Autoicous. Sporophytes frequent. Perichaetial leaves 2.1-2.3 $\times 1 \mathrm{~mm}$, smooth, costa double. Seta 1.5-2.5 cm. Capsule 1.5-2.0 mm long, arcuate, smooth or slightly furrowed. Operculum obliquely rostrate. Exostome teeth pale, $0.40-0.48 \mathrm{~mm}$ long, abruptly narrowed in the transition zone, serrulate to nearly entire in the upper third; in the lower part striolate, with perfect cristae; in the middle densely papillose on few plates; in the upper part with low small rare papillae; dorsal trabeculae prominent, with more high conic-spinulose papillae; ventral surface and trabeculae rugose, with sparse spinulose papillae. Endostome $0.45 \mathrm{~mm}$ long, basal membrane $0.14 \mathrm{~mm}$ high; cilia appendiculate. Spores 10-13 $\mu \mathrm{m}$.

Distribution: The species of nearly cosmopolitan distribution, known in most of the regions of the Holarctic (being especially common in boreal forests), deeply penetrating to the Arctic, and reoprted far to the south in Macaronesia, South Africa, Australia, and Antarctic islands. In Altai P. denticula- 

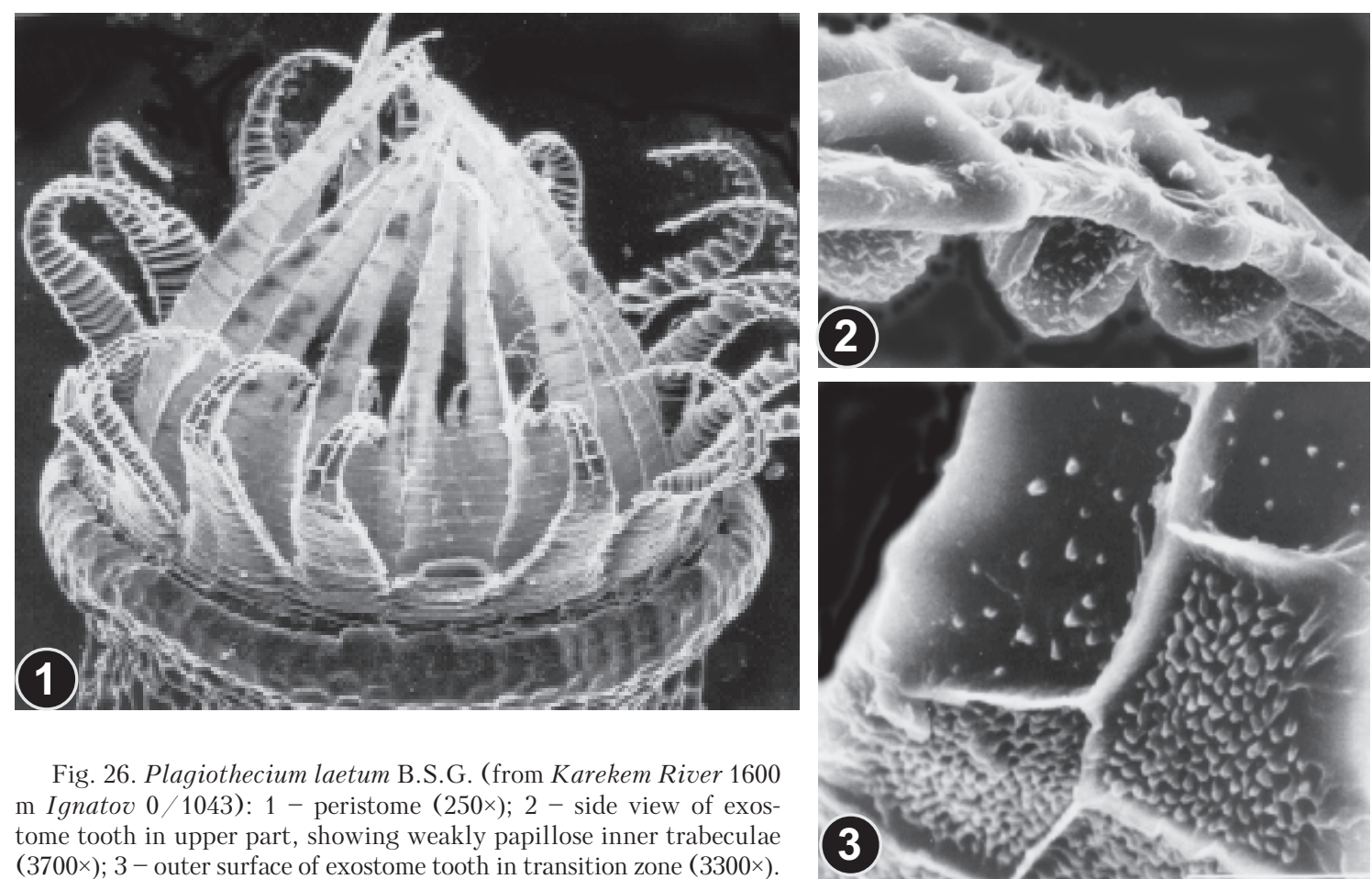

Fig. 26. Plagiothecium laetum B.S.G. (from Karekem River 1600 m Ignatov 0/1043): 1 - peristome (250×); 2 - side view of exostome tooth in upper part, showing weakly papillose inner trabeculae $(3700 \times) ; 3-$ outer surface of exostome tooth in transition zone $(3300 \times)$.

tum is common in mixed and conifer forests growing on trunk bases, rotten wood, rocks and on soil; in the alpine zone it grows mostly among big rocks in rock-fields and as a minor component on soil banks along stream beds and so on.

Specimens examined: Ayukol $1350 \mathrm{~m}(0 / 1249) ; A y u-$ lyuyuzyuk Creek $2450 \mathrm{~m}(0 / 167) ;$ Bayas Lake $1750 \mathrm{~m}$ (0/2093a); Bolshoye Istyube Creek $470 \mathrm{~m}(18 / 60)$; Bolshoye Kurkure Creek, upper course $2300 \mathrm{~m}$ (Galanin 9.VIII.1976); Itykul Lake $1800 \mathrm{~m}$ (Makhatkov \& al. 2.VIII.1978); Kairu Creek, 8 km upstream 1000 m (15 113); Kairu-Bazhi Peak 2050 m (13/110); Kamga Bay 440 m (Zolotukhin 20.X.1988); Kamga Creek, 13 km upstream 600 m (0/101); Karakol Lakes 1900 m (26/126); Kayakkatuyarykskij Creek $1920 \mathrm{~m}(3 / 261 ; 3 / 270), 1940 \mathrm{~m}$ (3/152); Kishte $440 \mathrm{~m}$ (Zolotukhin 11.VII.1988); Kobiguayuk Creek $2200 \mathrm{~m}(0 / 1247), 2300 \mathrm{~m}(0 / 307 ; 0 / 662)$; Lesnoi Creek, upper course $2600 \mathrm{~m}$ (Zolotukhin 1.VII.1990); Tamanel Peak 2150 m (34/89); Trekhglavaya Peak 2850 m (Zolotukhin 19.VII.1990); Uedinennoye Lake 880 m (0 / 1245); Yailyu $440 \mathrm{~m}(0 / 1246), 450 \mathrm{~m}(0 / 661)$.

Plagiothecium laetum B.S.G., Bryol. Eur. 5: 185. t. 495. 1851.

Figs. $25 \& 26$

Plants small to medium-sized, in green to whitish-green glossy mats. Stem irregularly branched, to $1.5 \mathrm{~cm}$ long, strongly complanate, with central strand and non-enlarged, thin-walled epidermal cells. Axillary hair 3-4-celled, 150-200 $\mu \mathrm{m}$ long, apical cell $45-55 \times 10-11 \mu \mathrm{m}$. Leaves 0.9-1.3 × 0.3-0.4 mm, ovate, usually recurved nearly throughout, asymmetric, with unequal decurrencies, the upper decurrency wider, 40-45 $\mu \mathrm{m}$ wide. Laminal cells 80-120 × 5-7 (4-6/1) $\mu \mathrm{m}$. In the decurrencies cells rectangular, ca. $50 \times 12$ $\mu \mathrm{m}$, in 3-4 rows.

Autoicous. Sporophytes frequent. Perichaetial leaves 0.9-1.1 $\times 0.5 \mathrm{~mm}$. Seta $1.5 \mathrm{~cm}$. Capsule 1-1.5 $\mathrm{mm}$ long, slightly arcuate to straight. Operculum obliquely rostrate. Exostome teeth pale, 0.40-0.45 $\mathrm{mm}$ long, abruptly narrowed in the transition zone, serrulate to nearly entire in the upper third; in the lower part striolate, with perfect cristae; in the middle densely papillose on few plates; in the upper part with low small rare papillae; dorsal trabeculae prominent; ventral surface and trabeculae rugose, with sparse small papillae. Endostome 0.4 $\mathrm{mm}$ high, basal membrane ca. $0.07 \mathrm{~mm}$ high; segments narrow and not perforated; cilia nodose. Spores $8-13 \mu \mathrm{m}$.

Though there are many characters to distinguish Plagiothecium laetum and P. denticulatum, some forms are difficult to interpret, since they have narrow decurrencies, but wide laminal cells. The latter character seems more reliable in such cases.

Distribution: Plagiothecium laetum is a bipolar disjunct species, very common throughout the boreal zone of the Northern Hemisphere, and sporadic also in the Arctic and temperate zones. In Altai it is confined to the forest zone and has never 


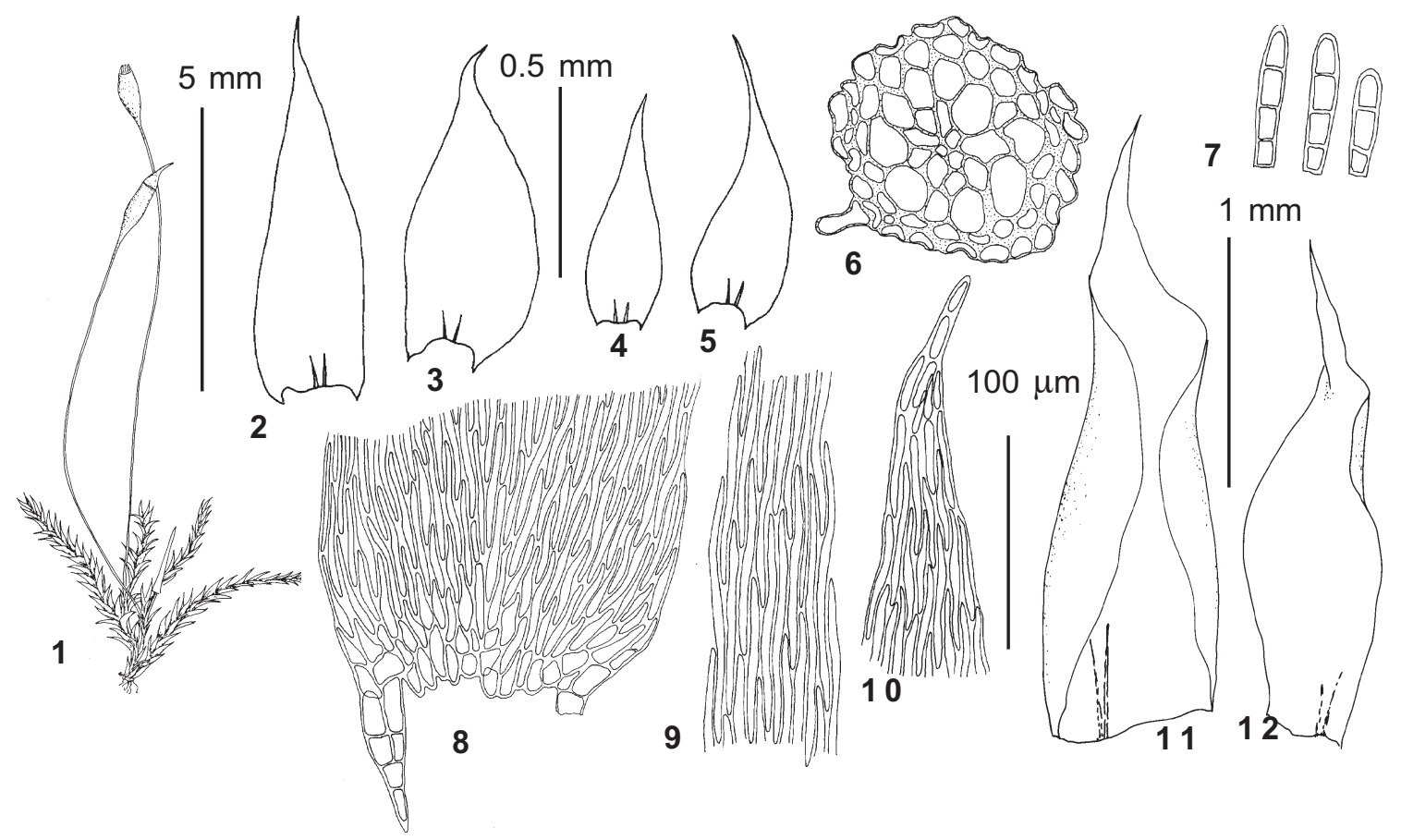

Fig. 27. Plagiothecium latebricola B.S.G. (from Bolshoye Istyube Creek $470 \mathrm{~m}$ Ignatov 18/15): 1 - habit; 2-5 leaves; 6 - stem cross-section; 7 - gemmae; 8 - cells of leaf base; 9 - middle laminal cells; 10 - upper laminal cells; 11-12 - perichaetial leaves. Scale bars: $5 \mathrm{~mm}$ - for $1 ; 1 \mathrm{~mm}$ - for $11-12 ; 0.5 \mathrm{~mm}$ - for 2-5; $100 \mu \mathrm{m}-$ for $6-10$.

been found above the tree-line. It grows on trunks and rotten wood, but only occasionally can be found on soil (where P. denticulatum is not rare).

Specimens examined: Ayukol $1000 \mathrm{~m}(0 / 1040) ;$ Ayulyuyuzyuk Creek $2100 \mathrm{~m}(0 / 384)$; Bayas Lake $1800 \mathrm{~m}$ (0 /663); Bolshoye Istyube Creek $470 \mathrm{~m}(0 / 1248 ; 18$ 19a); Kairu Creek, 16 km upstream $1400 \mathrm{~m}$ (14/42); Kamga Bay 440 m (Zolotukhin 20.X.1988); Kamga Creek, 13 km upstream $600 \mathrm{~m}(0 / 1044), 630 \mathrm{~m}(0 / 1042)$; Karakem River, 6 km upstream $1600 \mathrm{~m}$ (0/1043); Karakol Lakes $1900 \mathrm{~m}$ (28/149); Kayakkatuyarykskij Creek 1760 $\mathrm{m}(8 / 222), 1900 \mathrm{~m}(8 / 36), 1920 \mathrm{~m}(3 / 160), 1950 \mathrm{~m}$ (8 85), 2000 m (3/86); Kyga River, 2 km upstream $600 \mathrm{~m}$ (0/1041); Oimok 1100 m (Zolotukhin 25.VIII.1986); Saluru Creek, upper course 2250 m (36/112); Srednij Shaltan Creek $620 \mathrm{~m}(0 / 1045) ;$ Tura Creek, in middle course $1300 \mathrm{~m}(28 / 29 ; 28 / 49)$; Yailyu $460 \mathrm{~m}(0 / 662)$, $480 \mathrm{~m}(0 / 1046)$.

Plagiothecium latebricola B.S.G., Bryol. Eur. 5: 184. t. 494. 1851. - Philoscia latebricola (B.S.G.) Berk., Handb. Brit. Moss. 146. 1863.

Figs. $27 \& 28$

Plants small, up $1 \mathrm{~cm}$ long, in green glossy mats. Stem irregularly branched, complanate. Leaves $0.6-1.0 \times 0.2-0.4 \mathrm{~mm}$, ovate-lanceolate, slightly asymmetric, the upper decurrency (1-)23-cell and 25-40 $\mu \mathrm{m}$ wide. Laminal cells 90-130 ×
$5(4 / 1) \mu \mathrm{m}$, in decurrencies ca. $48 \times 16 \mathrm{~mm}$. Gemmae in leaf axils and on leaf tips,3-4-celled,51-68 $\times 11-12 \mu \mathrm{m}$.

Dioicous. Sporophytes rather frequent. Perichaetial leaves $0.7-0.8 \times 0.2-0.4 \mathrm{~mm}$. Seta $1.0 \mathrm{~cm}$. Capsule \pm erect, $1.0 \mathrm{~mm}$ long. Exostome teeth pale, 0.35 $\mathrm{mm}$ long, abruptly narrowed in the transition zone, serrulate to nearly entire in the upper third; in the lower part \pm striolate, with cristae short, flexuose and intermixed with papillae; in the middle cristae becoming shorter and oblique to longitudinal; in the upper part with low small papillae arranged in longitudinal rows; dorsal trabeculae indistinct, with nonincrassate margin; ventral surface and trabeculae slightly rugose, without papillae. Endostome $0.3 \mathrm{~mm}$ long, basal membrane low; cilia short or reduced. Spores ca. $10 \mu \mathrm{m}$.

This species is easily recognized by the relatively small size and eroded leaf tips (gemmae themselves are not common). Crundwell (1979) reported cauline rhizoids in $P$. latebricola, whereas leaf-borne in other Plagiothecium species. According to our observation most rhizoids in $P$. latebricola have the same position as in other species of the genus and stem- 

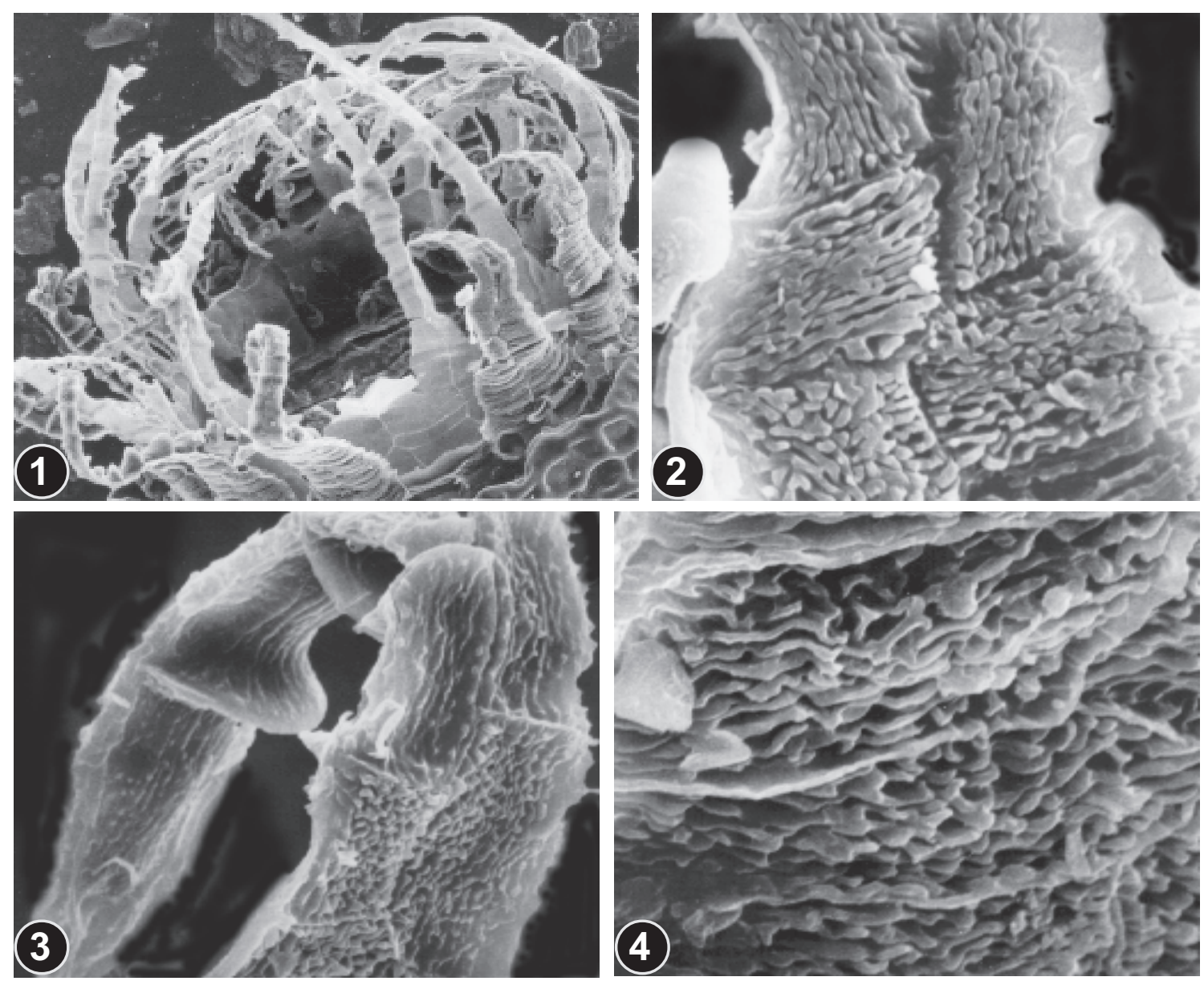

Fig. 28. Plagiothecium latebricola B.S.G. (from Bolshoye Istyube Creek $470 \mathrm{~m}$ Ignatov 18/15): 1 - peristome $(360 \times) ; 2$ - outer surface of exostome tooth in transition zone $(3200 \times) ; 3$ - upper part of exostome tooth $(3000 \times)$; 4 - outer surface of exostome tooth in lower part $(6000 \times)$.

borne only in proximal branches, agreeing with the pattern observed in other species of Plagiothecium.

Distribution: Plagiothecium latebricola is a rather rare species in most areas where it is known, at least in the territory of the former USSR. However it has been found in most of carefully explored boreal regions. It si also known from most of the European countries, Turkey and North America. As some other epixylic boreal species, $P$. latebricola does not penetrate into the Arctic, or to areas dominated by steppes, and also is rare in broad-leaved forests. In Altai P. latebricola was collected on strongly rotten wood in a wet shady canyon rich in decaying wood.

Specimens examined: Bolshoye Istyube Creek $470 \mathrm{~m}$ $(0 / 1250 ; 18 / 15)$

\section{Herzogiella Broth.}

This genus is characterized by thin-wall epidermal cells and leaves non-decurrent and serrate throughout. However, the type of Herzogiella, the South American H. boliviana, may not be very close to species of the Northern Hemisphaere (Buck \& Ireland, 1985). If further studies find them different, the correct generic name for the Holarctic species will be Sharpiella Iwats., J. Hattori Bot. Lab. 28: 202. 1965. The latter group includes about 5 species, in the boreal and temperate zones.

In Herzogiella ascendens (Lindb.) Iwats. et Schof., a North-Pacific species, rhizoids are clustered just below the leaf insertion, pseudoparaphyllia present and branching is regularly pinnate, so it seems closer to Hypnum sect. Breidleria. 


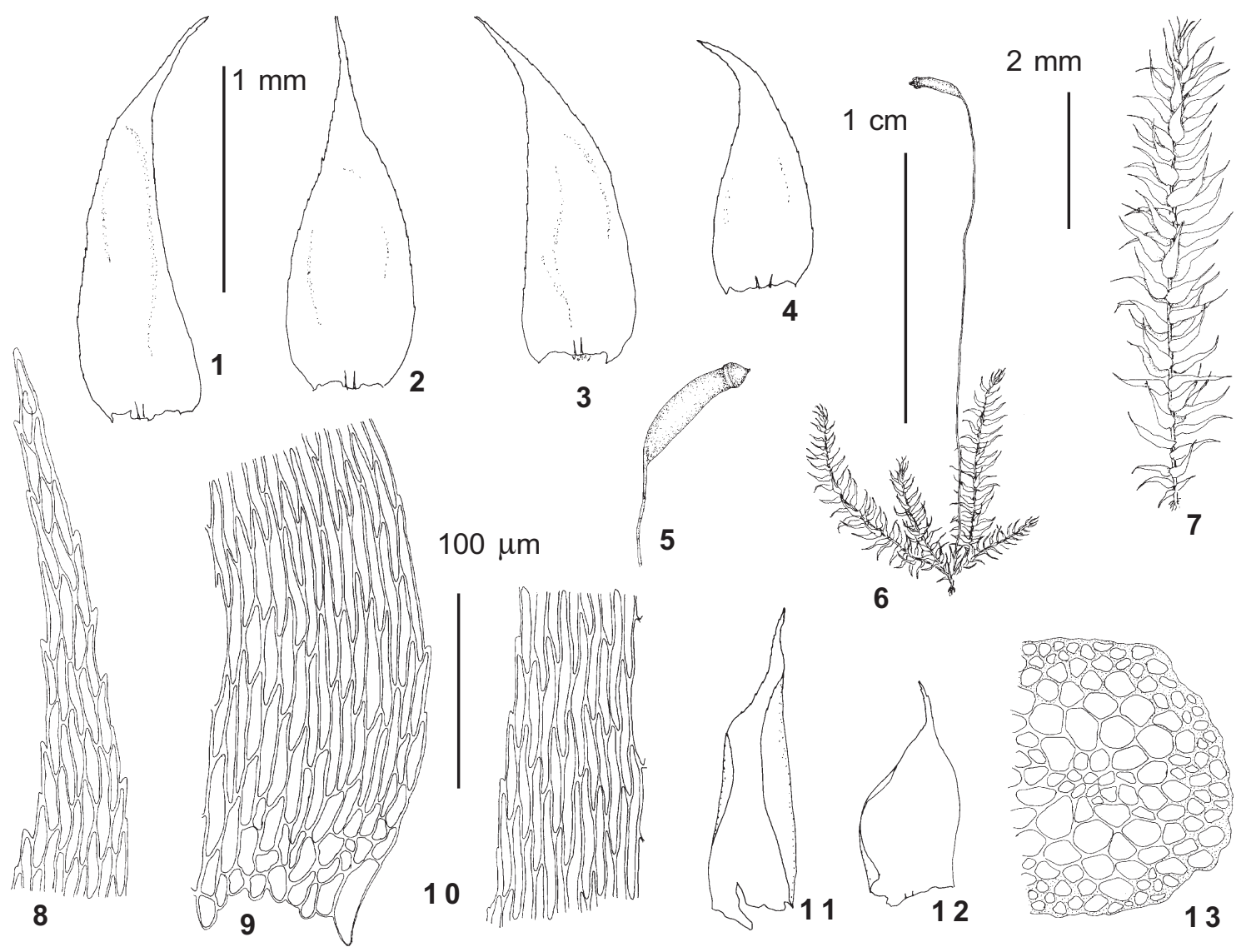

Fig. 29. Herzogiella seligeri (Brid.) Iwats. (from Kazakh Altai, Riddera, Polyakov 371): 1-4-leaves; 5 - capsule; 6 - habit; 7 - shoot; 8 - upper laminal cells; 9 - basal cells; 10 - middle laminal cells; 11-12 - perichaetial leaves; 13 stem cross-section. Scale bars: $1 \mathrm{~cm}$ - for $6 ; 2 \mathrm{~mm}$ - for 5,$7 ; 1 \mathrm{~mm}$ - for 1-4, 11-12; $100 \mu \mathrm{m}$ - for 8-10, 13.

Herzogiella seligeri (Brid.) Iwats., J. Hattori Bot. Lab. 33: 374. 1970 - Leskea seligeri Brid., Musc. Recent. 2(2): 47. 1801 -Sharpiella seligeri (Brid.) Iwatsuki, J. Hattori Bot. Lab. 28: 203. 1965.

Figs. $29 \& 30$

Plants medium-sized, in glossy green or whitish-green tufts. Stem prostrate, rarely irregularly branching, to $2 \mathrm{~cm}$ long, with central strand; epidermal cells thin-walled, small. Axillary hairs 3-4celled, 70-90 $\mu \mathrm{m}$ long, apical cell $30 \times 8 \mu \mathrm{m}$. Rhizoids situated usually in between leaves, not strictly above the center of the leaf below, rarely in more clear rows above the leaf axil. Leaves spreading, falcate, ca. $(1.0-) 1.2-2.0 \times 0.4-0.7 \mathrm{~mm}$, lanceolate; costa double; margins serrate above, serrulate below to the base. Laminal cells 70-95 × 7-6 (5-6/1) $\mu \mathrm{m}$; at base shorter, in leaf corners practically not differentiated.

Autoicous. Sporophytes frequent. Perichaetial leaves $1.3-1.5 \times 0.4 \mathrm{~mm}$. Seta to $2.2 \mathrm{~cm}$ long. Capsule $2-2.3 \mathrm{~mm}$ long, curved and horizontal. Operculum conic. Annulus of large separating cells. Exos- tome teeth ca. $0.40 \mathrm{~mm}$ long, \pm abruptly tapered in the transition zone, entire; in the lower part imperfectly striolate (cristae smooth); in the middle densely papillose (papillose zone of few plates); in the upper part with irregularly scattered small conicspinulose papillae; dorsal trabeculae and non-incrassate margin with conic papillae; ventral surface and trabeculae with rare spinulose papillae. Endostome $0.40 \mathrm{~mm}$ long, basal membrane $0.20 \mathrm{~mm}$ long, segments not perforate; cilia nodose (rarely appendiculate). Spores $14 \mu \mathrm{m}$.

Distribution: In both Eurasia and North America, Herzogiella seligeri occurs mostly in western regions: in America - from British Columbia to Oregon, eastward to Montana and Idaho; in Eurasia - in most countries (especially abundant in beech forests), eastward to Urals and Caucasus. In Asia H. seligeri is known from a few localities in China (Redfearn \& al., 1996) and in Kazakh Altai, close to the border of Russian Altai, and probably will be found in the western part of the latter. All collections were made in Abies forests.

Specimen examined: Kazakh Altai, Riddera, Polyakov 371. 


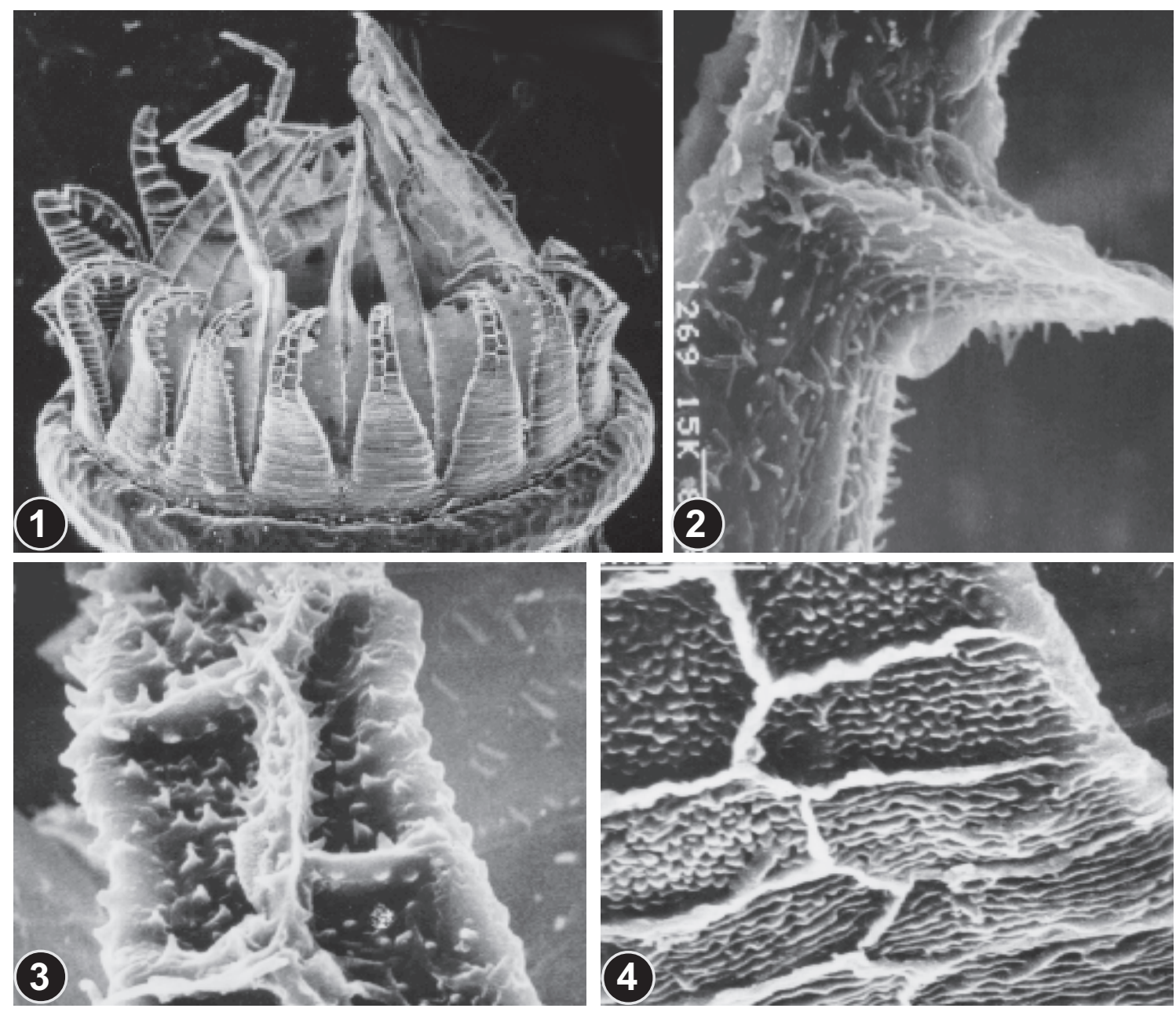

Fig. 30. Herzogiella seligeri (Brid.) Iwats. (from Moscow Province, Ignatov 4.VII.1987 (MHA)): 1 - peristome $(250 \times) ; 2$ - inner side of exostome tooth in upper part, showing papillose inner trabecula $(4800 \times)$; 3 - outer surface of exostome tooth in upper part $(3600 \times) ; 4$ - outer surface of exostome tooth in transition zone $(3600 \times)$.

Hypnaceae Schimp.

A big and heterogeneous family of pleurocarps, characterized by (1) straight to falcatesecund leaves with short double costa; (2) alar cells often differentiated, but not vesiculateinflated; (3) pseudoparaphyllia present; (4) rhizoids inserted below the leaf insertion; (5) exostome cross-striolate to papillose, with a zigzag centre line and well developed ventral trabeculae; (6) endostome with \pm high basal membrane and broad, keeled, narrowly perforated segments, and usually with nodose cilia. Some to nearly all of these main charachters are present also in various groups of Sematophyllaceae, Entodontaceae, Hylocomiaceae, Plagiotheciaceae, and Amblystegiaceae, so the limits of the Hypnaceae with these families remain disputable. In the course of revisions of these families many genera were transferred to Hypnaceae. However these attempts to increase the naturalness of Sematophyllaceae, Plagiotheciaceae, Entodontaceae, etc. have resulted in an enormous inflation of the Hypnaceae.

The following genera, found in Altai, pose problems of familial alliance:

Hypnaceae/Hylocomiaceae: Gollania, Rhytidiadelphus, Pleurozium;

Hypnaceae/Plagiotheciaceae: Taxiphyllum, Isopterygiopsis, Herzogiella, Orthothecium;

Hypnaceae/Entodontaceae: Platygyrium, [Orthothecium];

Hypnaceae/Sematophyllaceae: Heterophyllium, Struckia;

Hypnaceae/Amblystegiaceae: Campylium 
s. 1. (incl. Campyliadelphus and Campylophyllum), Calliergonella, Psuedohygrohypnum.

These genera are discussed in corresponding genera or families, except the Amblystegiaceae which will be treated in a separate paper.

Altaian members of the Hypnaceae belong mostly to the subfamily Hypnoideae as it was defined by Nishimura \& al. (1984). The relatively homogeneous group around Hypnum includes Callicladium, Eurohypnum, Gollania, Ptilum, Homomallium, and Heterophyllium. Especially distinct is Pylaisiella, comprising the small subfamily Pylaisielloideae. The recently described Podperaea is referred here to Ctenidioideae, to which belongs its close relative Mittenothamnium. We place Taxiphyllum in Hypnaceae, not in Plagiotheciaceae, however in the former its position is also rather isolated. Preliminary placement of Taxiphyllum in Hypnoideae is probably not exact, and maybe Taxiphyllum and Isopterygium s. str. need their own subfamily.

Subfamily Pylaisielloideae Fleisch.

The subfamily is characterized by straight leaves, erect capsules with advanced peristome characters.

\section{Pylaisiella Kindb.}

This genus includes ca. 30 species, distributed in temperate regions, with $2-3$ species in the boreal zone. Pylaisiella differs from other members of Hypnaceae in the perfectly straight capsule and in structure of both endostome and exostome. Cilia of endostome are short and without appendicules. Exostome teeth are (1) heavily papillose on the outer surface above; (2) dorsal trabeculae in proximal tooth high and plates between them are smooth; (3) the inner layer of the teeth (derived from PPL) is thick due to deposition of additional material. These peculiarities cause anomalous hygrocastique hygroscopic movements - the teeth are \pm involute when dry and become erect to somewhat reflexed when wet (this character seen in $P$. polyantha, $P$. selwynii, $P$. brotheri and $P$. intricata). In this respect Pylaisiella differs from most boreal pleurocarps, and resembles many tropical mosses and, in the northern bryoflora, Neckera, Leucodon, Homalothecium, Entodon, Anomodon, and Leskeaceae (Leskea, Iwatsukiella, Myrinia, etc.). These genera disperse spores in wet periods (usually in the cool half of the year) and keep capsules \pm closed in dry periods. This pattern can be assumed to be an adaptation to the true epiphytic life (Mueller \& Neumann, 1988). However, the pattern of hygroscopic movements is hardly enough to segregate Pylaisiella in its own family, since this character is variable within many families: Neckeraceae (xerocastique, or involute when wet in Homalia/ hygrocastique in Neckera \& many other genera), Brachytheciaceae (hygrocastique in Homalothecium and some Rhynchostegiella / xerocastique in many other genera), etc.

\section{Key tO THE Altaian SPECIES OF PYLAISIELLA}

1. Branches strongly curved; alar cells numerous, to 25 along the margin; capsule ovoid; exostome and endostome tightly attached to each other, and fused below; spores 18$30 \mu \mathrm{m} . . . \ldots \ldots \ldots \ldots \ldots$. P. selwynii

1. Branches straight to little-curved; alar cells less numerous, to 15 along the margin; capsule \pm cylindric; exostome and endostome not attached to each other; spores 12-19 $\mu \mathrm{m}$

..................... P. polyantha

Pylaisiella polyantha (Hedw.) Grout, Bull. Torrey Bot. Club 23: 229. 1896. - Leskea polyantha Hedw., Sp. Musc. 229. 1801. Figs. 31 \& 32

Plants medium-sized, yellow-green to goldenbrownish, glossy. Stem creeping, $4 \mathrm{~cm}$ long, \pm regularly branched,branches $5-6 \mathrm{~mm}$ long; tips of stem and branches often \pm arcuate; epidermal cells of stem thick-walled; central strand well-developed. Pseudoparaphyllia narrowly triangular, strongly serrate to incised. Axillary hairs 4-celled, 100-110 $\mu \mathrm{m}$ long, apical cell 40-50 $\times 9-10 \mu \mathrm{m}$. Stem leaves straight, 1.2-1.5 $\times 0.4-0.5 \mathrm{~mm}$, ovate-lanceolate; margins plane, entire. Branch leaves 1.0-1.1 ×0.3-0.4 mm. Laminal cells $35-70 \times 5-7$ (4-5.5/1-1.5) $\mu \mathrm{m}$. Alar cells subquadrate, forming a triangular indistinctly delimited group, ca. 15 along the margin.

Autoicous. Sporophytes frequent. Perichaetial leaves $1.4-1.5 \times 0.4-0.5 \mathrm{~mm}$, smooth. Seta ca. $1 \mathrm{~cm}$. Capsule $1.5 \mathrm{~mm}$ long, straight, cylindric. Operculum conic. Annulus of 3 rows of rectangular cells, partly deciduous, but almost indistinctly delimited from the lower cells. Exostome teeth $0.3 \mathrm{~mm}$ long, gradually tapered, entire, on the outer surface with high trabeculae. Dorsal trabeculae smooth in proximal tooth, in the upper $2 / 3$ papillose and incrassate; papillae large, high and often forked. Plates in between trabeculae moderately roughened with low round papillae to rugose. Ventral trabeculae heavily 


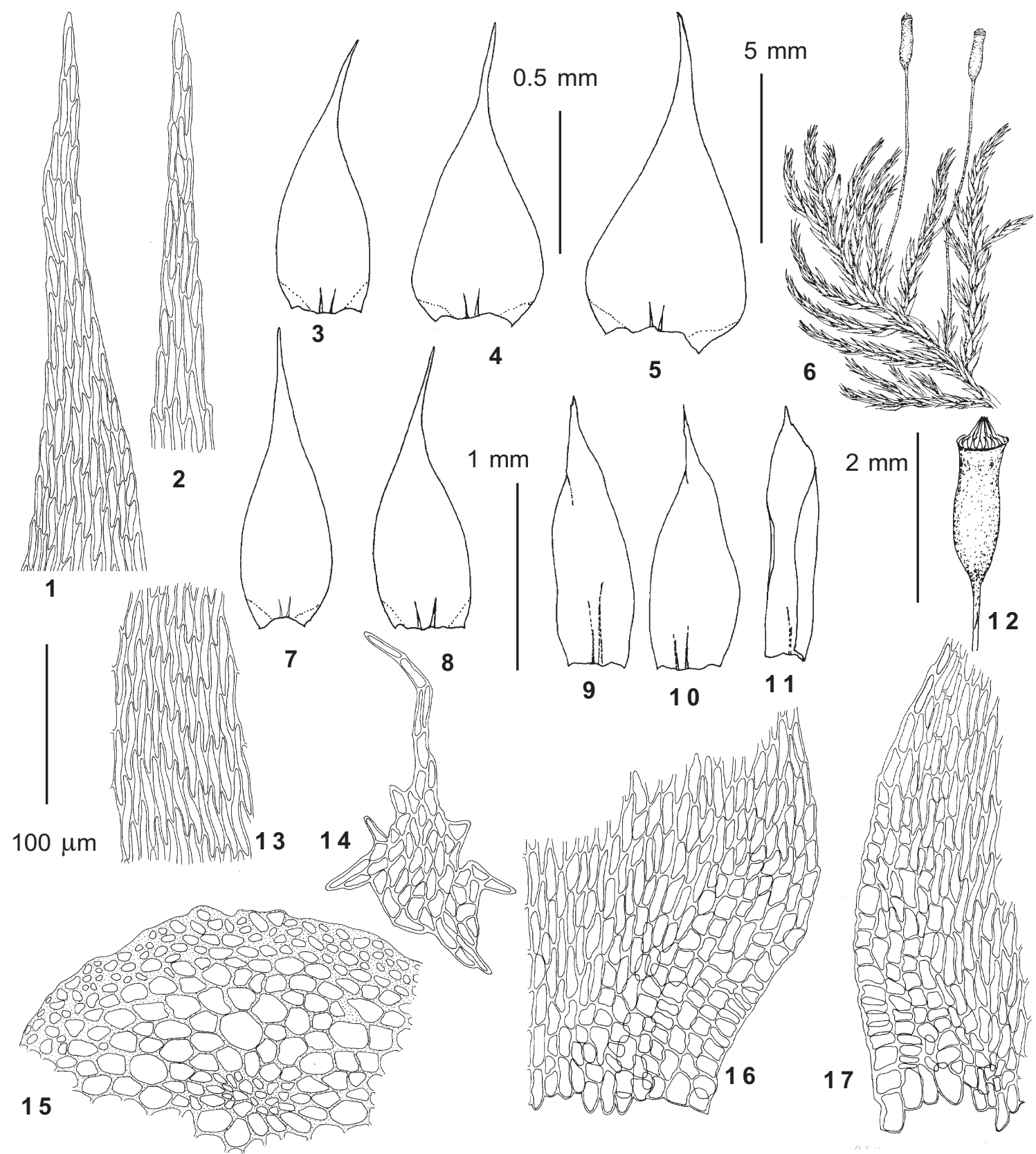

Fig. 31. Pylaisiella polyantha (Hedw.) Grout (from Adylda Creek 1100 m Ignatov 34/130): 1 - upper laminal cells of branch leaf; 2 - upper laminal cells of stem leaf; 3-5 - stem leaves; 6 - habit; 7-8 - branch leaves; 9-11 perichaetial leaves; 12 - capsule; 13 - middle laminal cells of stem leaf; 14 - pseudoparaphyllium; 15 - stem crosssection; 16 - alar cells of stem leaf; 17 - alar cells of branch leaf. Scale bars: $5 \mathrm{~mm}-$ for $6 ; 2 \mathrm{~mm}-$ for $12 ; 1 \mathrm{~mm}-$ for $9-11 ; 0.5 \mathrm{~mm}$ - for $3-5,7-8 ; 100 \mu \mathrm{m}$ - for $1-2,13-17$.

incrassate, rugose. Endostome free, $0.35 \mathrm{~mm}$ long, with basal membrane ca $0.12 \mathrm{~mm}$ high, segments \pm papillose above; cilia short to absent. Spores $12-19 \mu \mathrm{m}$.

Distribution: This species is widely distributed throughout the Holarctic, from the northern limit of trees to the subtropical zone. In Altai $P$. polyantha never exceeds tree-line. Collection were made from trunks and twigs (Populus, Salix, Betula, Sorbus, Padus, Abies) at lower elevations, and sometimes from rotten logs and stumps. Above $1400 \mathrm{~m}$ it grows mostly on rocks, and bases of shrubs of Caragana and Rhododendron. 

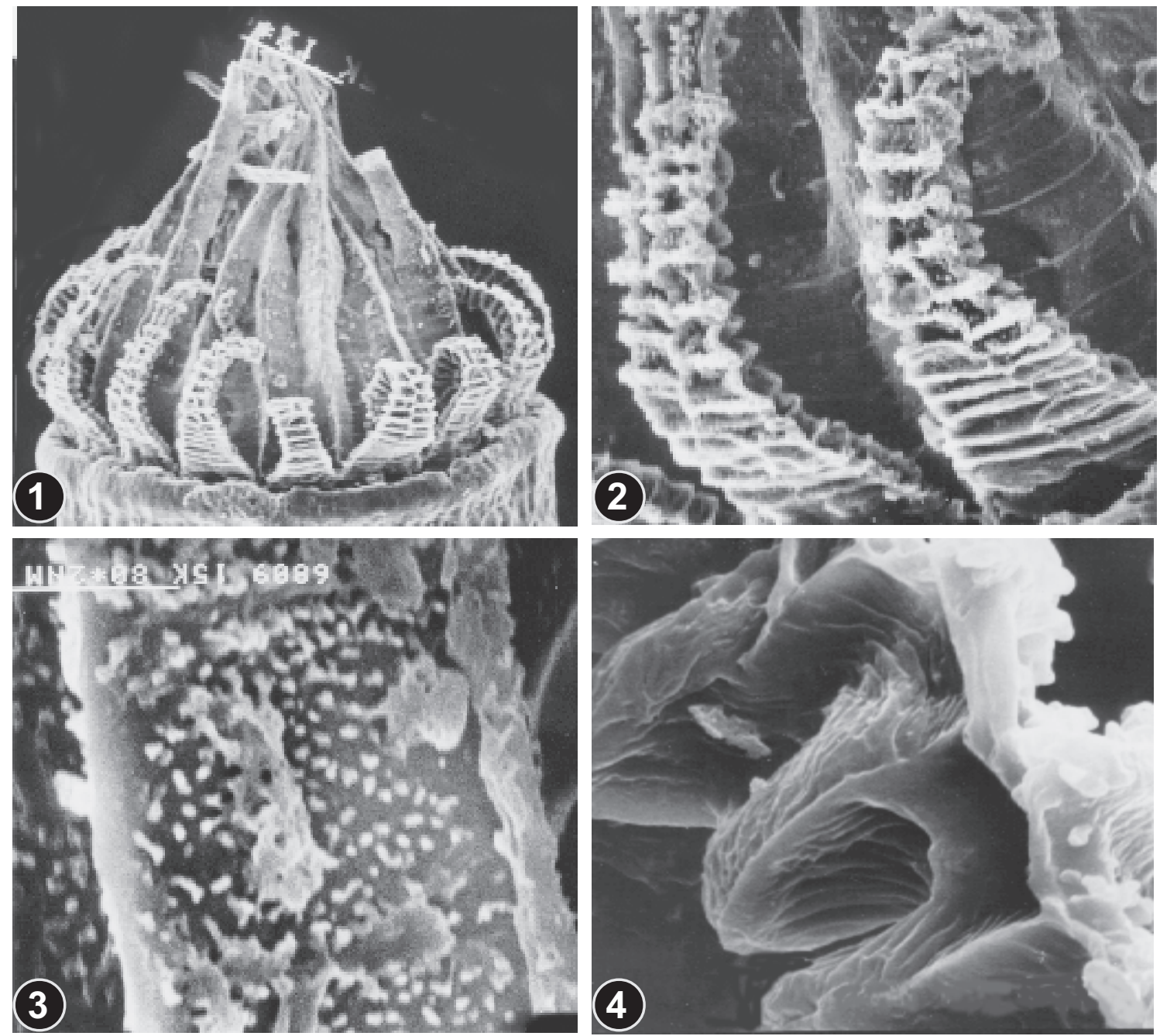

Fig. 32. Pylaisiella polyantha (Hedw.) Grout (from Bele $500 \mathrm{~m}$ Ignatov 0/79): 1 - peristome (330×); 2 - outside view of exostome teeth $(1150 \times)$; 3 - outer surface of endostome in the middle $(4250 \times)$; 4 - side view of upper part of exostome tooth, showing strongly incrassate inner trabeculae $(5700 \times)$.

Specimens examined: Adylda Creek $1100 \mathrm{~m}$ (34/130; 34/ 82); Akkurum $550 \mathrm{~m}$ (Zolotukhin 22.IX.1989); Ayukol $950 \mathrm{~m}$ $(0 / 1199)$; Bele $500 \mathrm{~m}(0 / 79)$; Berekhtuyaryk $1600 \mathrm{~m}(0 /$ 1695), $1640 \mathrm{~m}$ (0/608); Bolshoi Yaloman Creek, in middle course $1500 \mathrm{~m}$ (Makarov \& al. 15.VII.1972); Chemal, $5 \mathrm{~km}$ to the SE $500 \mathrm{~m}$ (Makarov 28.VI.1972); Chiri Creek, $0.5 \mathrm{~km}$ upstream $450 \mathrm{~m}(17 / 22 ; 17 / 87)$; Chodro $900 \mathrm{~m}$ (Lebedeva \& al. 25.VIII.1979); Chulcha River, in middle course $1000 \mathrm{~m}$ (9 47); Elekmonar Creek, 5 km upstream $700 \mathrm{~m}$ (26/38; $26 / 43)$; Kamga Creek, 2 km upstream 450 m (Zolotukhin 20.X.1988); Kamga Creek, at mouth 440 m (Zolotukhin 20.X.1988); Kar akem River, 6 km upstream $1600 \mathrm{~m}(0 / 1195)$; Karatyt $1300 \mathrm{~m}$ (Zolotukhin 20.II.1990); Kayakkatuyarykskij Creek $1850 \mathrm{~m}$ (8/293), $1940 \mathrm{~m}(3 / 246)$; Korbu $440 \mathrm{~m}(0 / 1197), 450 \mathrm{~m}$ (Zolotukhin 20.X.1988); Kukol 1800 m (0/609); Maima 280 m (35/23); Malyi Yaloman $1100 \mathrm{~m}(25 / 6 ; 25 / 88) ;$ Malyi Yaloman Creek, 8 km upstream $1100 \mathrm{~m}(25 / 19)$; Srednij Shaltan Creek $640 \mathrm{~m}$ (0/1196); Ust-Sema $400 \mathrm{~m}(24 / 160)$; Yailyu $440 \mathrm{~m}$ (0/610), $450 \mathrm{~m}$ (Zolotukhina 14.VII.1988).
Pylaisiella selwynii (Kindb.) Crum, Steere et Anderson, Bryologist 67(2): 164. 1964. - Pylaisia selwynii Kindb., Ottawa Naturalist 2: 156. 1889. - Pylaisia schimperi Card., Bull. Herb. Boiss. 7: 373. 1899.

Figs. 33 \& 34

Plants medium-sized, yellow-green, glossy. Stem creeping, $5 \mathrm{~cm}$ long, \pm regularly branched, branches 5-6 mm long,tips of stem and branches often arcuate to circinate when dry; epidermal cells of stem thick-walled; central strand ill-developed. Pseudoparaphyllia narrowly triangular, strongly serrate to incised. Axillary hairs 3-celled, 100-110 $\mu \mathrm{m}$ long, apical cell $65 \times 10 \mu \mathrm{m}$. Stem leaves straight, 1.0 $1.2 \times 0.4-0.5 \mathrm{~mm}$, ovate-lanceolate; margins plane, entire. Branch leaves $0.8-0.9 \times 0.2-0.3 \mathrm{~mm}$. Laminal cells $30-55 \times 7-8(3.5-4.5 / 3-3.5) \mu \mathrm{m}$. Alar cells sub- 


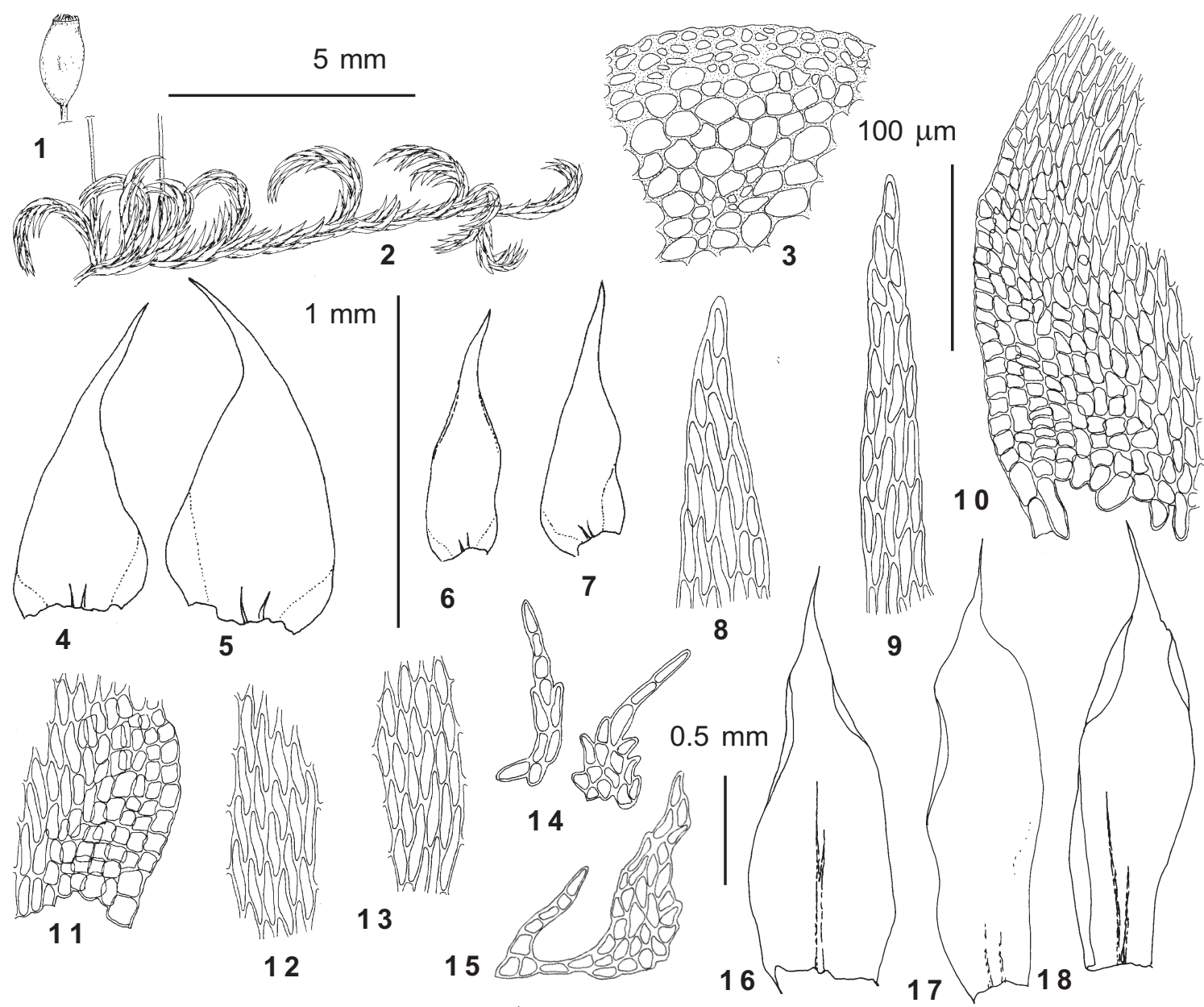

Fig. 33. Pylaisiella selwynii (Kindb.) Crum \& al. (from Kamga Creek, 2 km upstream $450 \mathrm{~m}$ Zolotukhin 20.X.1988): 1 - capsule; 2 - habit; 3 - stem cross-section; 4-5 - stem leaves; 6-7 - branch leaves; 8 - upper laminal cells of branch leaf; 9 - upper laminal cells of stem leaf; 10 - alar cells of stem leaf; 11 - alar cells of branch leaf; 12 middle laminal cells of stem leaf; 13 - middle laminal cells of branch leaf; 14-15 - pseudoparaphyllia; 16-18 perichaetial leaves. Scale bars: $5 \mathrm{~mm}$ - for $1-2 ; 1 \mathrm{~mm}$ - for $4-7 ; 0.5 \mathrm{~mm}$ - for $16-18 ; 100 \mu \mathrm{m}-$ for $3,8-15$.

quadrate, forming large indistinctly delimited group, reaching ca. 25 along the margin.

Autoicous. Sporophytes frequent. Perichaetial leaves 1.9-2.0 × 0.5-0.6 mm, entire; costa double, short to long, reaching mid-leaf. Seta ca. $1 \mathrm{~cm}$. Capsule 1.5 mm long, ovoid, straight, pale and often contrastingly colored below the mouth. Operculum conic. Annulus of 2-4 rows of quadrate and transversely rectangular cells, partly deciduous, but indistinctly delimited from the lower cells. Exostome teeth 0.25 $\mathrm{mm}$ long, gradually tapered, entire, with high dorsal trabeculae. Dorsal trabeculae smooth below, papillose in the upper $1 / 2-1 / 3$. Plates smooth below, with round low papillae above (of the same type as on the dorsal trabeculae). Ventral surface and high ventral trabeculae with somewhat larger dense papillae. Endostome as high as the teeth, in the lower $1 / 3$ adherent to the latter, in the upper part densely papillose, perforated and easily splitting off along the keel. Spores 20-32 $\mu \mathrm{m}$, roughly papillose.

More strongly curved shoots and ovoid (not cylindric) capsules allow differentiation of this species from Pylaisiella polyantha in the field with certainty.

Distribution: The distribution of Pylaisiella selwynii was mapped and discussed by Ignatov (1992). The species is common in East Asia and eastern North America, with limited occurrence in western sectors of both continents. In Altai (as well as in all other parts of Russia) this species grows exclusively as an epiphyte, mostly on Populus tremula, rarely on $P$. laurifolia, Salix, Betula, and confined to only lower elevations below $600 \mathrm{~m}$. On Populus tremula it grows to $10 \mathrm{~m}$ and more above the ground, especially if the trunk is somewhat inclined. Often in such cases $P$. selwynii is the only epiphyte species and forms pure 

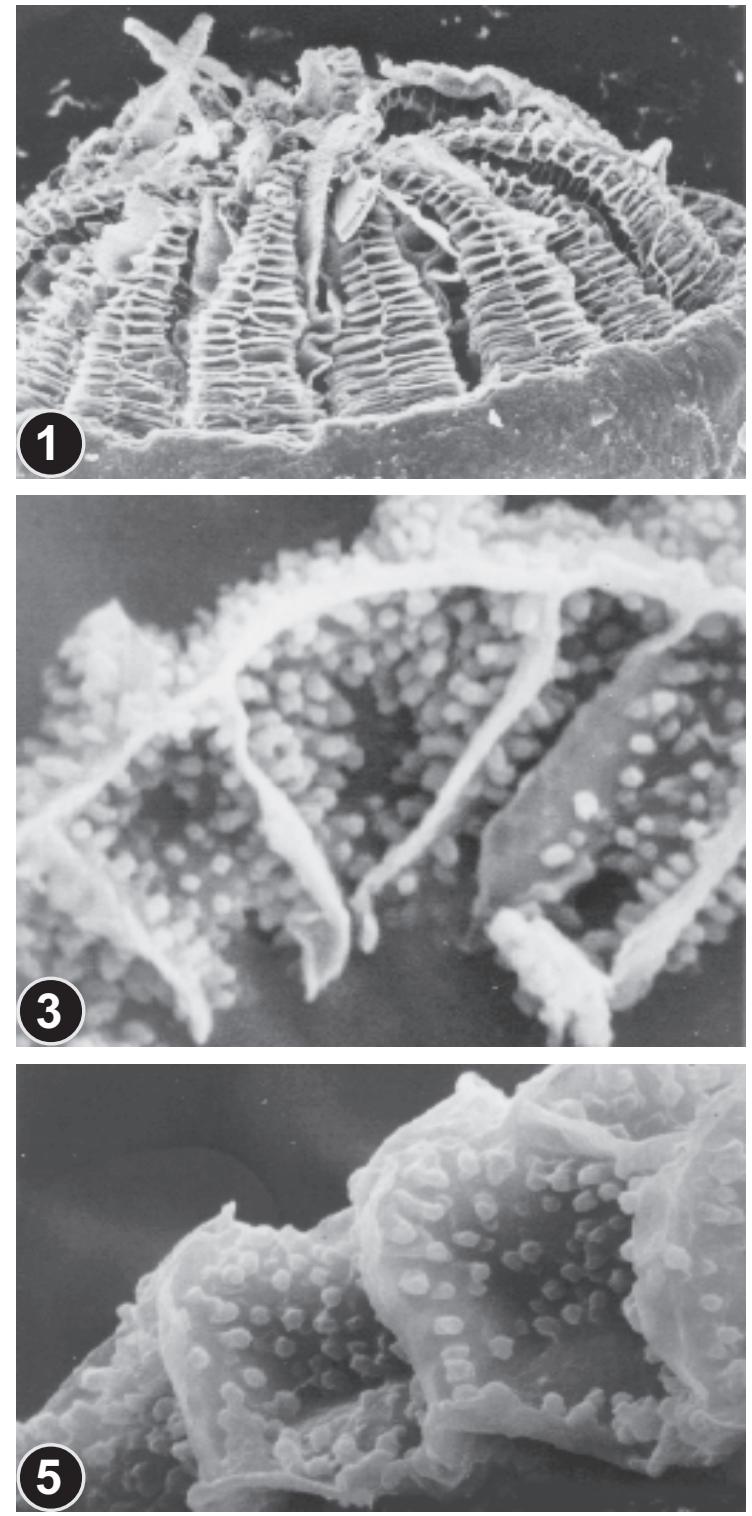

strips on the overhanging surface of the trunk (the mainstream of rain-water). In Gorno-Altaiask $P$. selwynii tolerates strong air pollution, occurring in the central part of the city on trunks of Populus with $P$. polyantha, Ceratodon purpureus (Hedw.) Brid., etc.

Specimens examined: Akkurum 500 m (Zolotukhin 21.IX.1989); Balykcha 450 m (Schischkin 6.IX.1931 LE!); Chemal Creek, 3 km upstream $450 \mathrm{~m}$ (34/135); Chulyshman River, at Bashkaus mouth $500 \mathrm{~m}$ (Zolotukhin 23.IX.1989); Gorno-Altaisk $400 \mathrm{~m}(35 / 16)$; Gorno-Altaisk (SE edge) $600 \mathrm{~m}(0 / 1198 ; 23 / 5)$; Kamga Creek, 2 $\mathrm{km}$ upstream $450 \mathrm{~m}$ (Zolotukhin 20.X.1988; 0/1201); Kamga Creek, 3 km upstream $460 \mathrm{~m}$ (0/1202); Korbu $440 \mathrm{~m}$ (Zolotukhin 20.X.1988); Kyrsai $450 \mathrm{~m}$ (Schischkin 4.IX.1931 LE!); Pyankovo (Vereshchagin 11.VI.1905 LE!); Yailyu $440 \mathrm{~m}$ (Zolotukhin 6.VIII.1988).
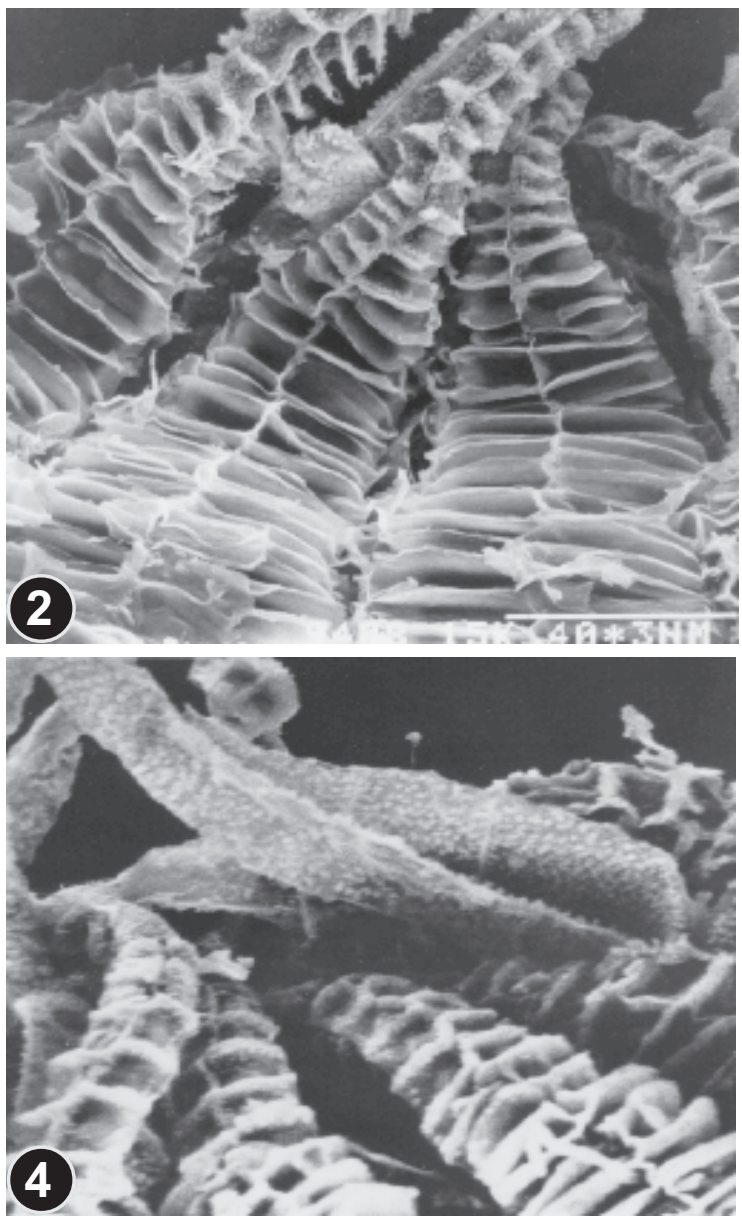

Fig. 34. Pylaisiella selwynii (Kindb.) Crum \& al. (1, 4 - from Kamga Creek 460 m Ignatov 0/1202; 2, 3, 5 from Chulyshman River 500 m Zolotukhin 23.IX.1988): 1 - peristome $(430 \times)$; 2 - outer surface of exostome teeth $(900 \times) ; 3$ - side view of exostome tooth in upper part, showing coarsely papillose both surfaces and trabeculae (4650×); 4 - part of peristome, showing densely papillose exostome segments $(1200 \times)$; 5 - outer trabeculae at about two-thirds of exostome tooth $(5500 \times)$.

\section{Subfamily Ctenidioideae Fleisch.}

The subfamily is characterized by tendencies to the marked differentiation of stem and branch leaves, non-falcate leaves, distinct leaf serration, prorate laminal cells, and weakly differentiated alar cells.

Podperaea Iwats. et Glime

This monotypic genus is distinct in having (1) strongly enlarged epidermal cells; (2) distinctly prorate laminal cells; (3) "double-celled" teeth at leaf margins formed by the curved upper end of lower cell and the curved lower end of upper cell. Iwatsuki \& Glime (1984) 


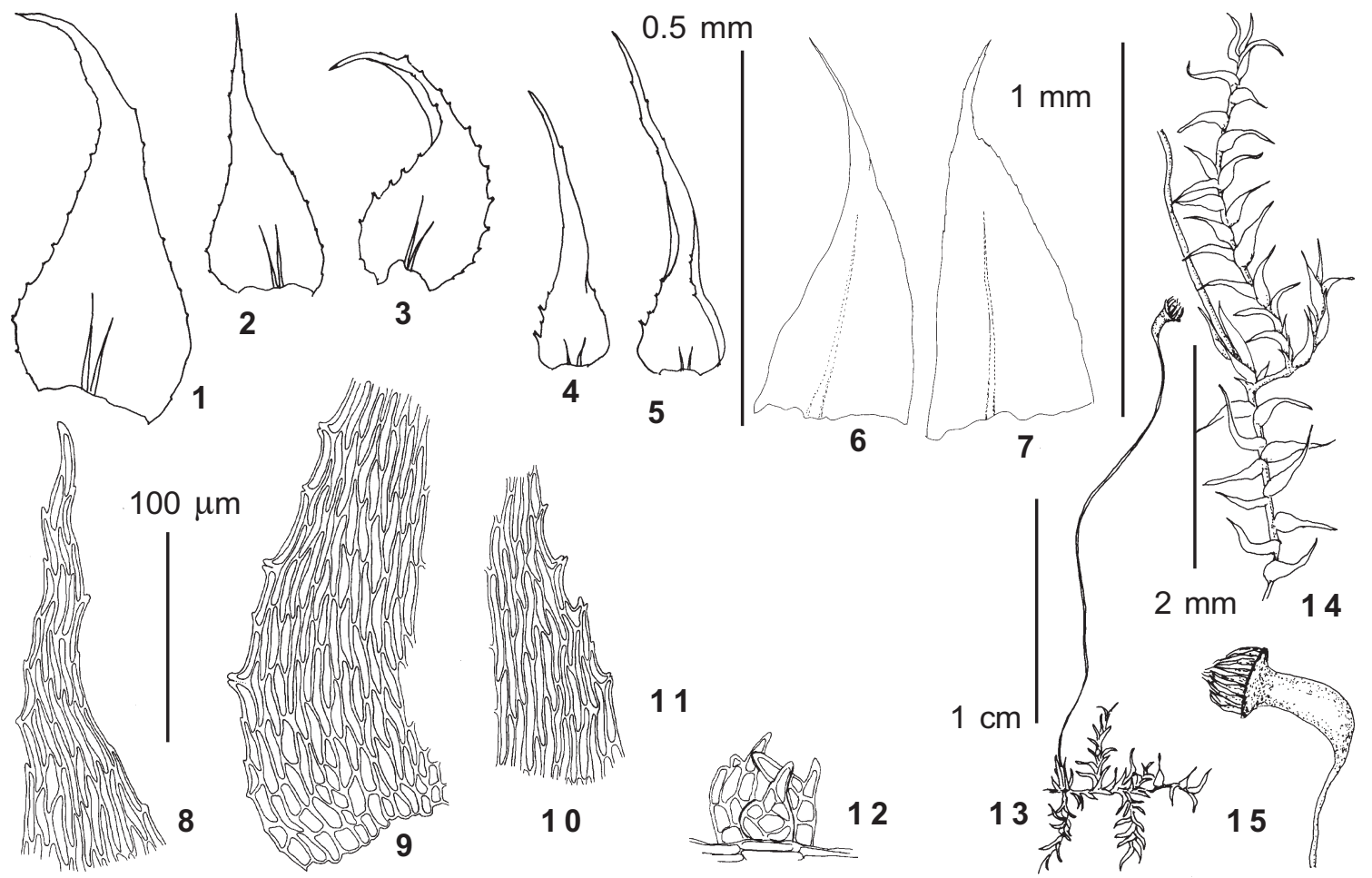

Fig. 35. Podperaea krylovii (Podp.) Iwats. et Glime (from Kobukhta $460 \mathrm{~m}$ Ignatov 0/626): 1-3 - stem leaves; 45 - branch leaves; 6-7 - perichaetial leaves; 8 - upper laminal cells of stem leaf; 9 - alar cells of stem leaf; 10 middle laminal cells of stem leaf; 11 - stem cross-section; 12 - pseudoparaphyllia; 13-14 - habit; 15 -capsule. Scale bars: $1 \mathrm{~cm}$ - for $13 ; 2 \mathrm{~mm}$ - for $14-15 ; 0.5 \mathrm{~mm}$ - for $1-5 ; 1 \mathrm{~mm}$ - for $6-7 ; 100 \mu \mathrm{m}$ - for $8-12$.

compared this genus with Mittenothamnium, which is close to Podperaea in prorate cells and some other details (general appearance, capsule shape, peristome characters), but differs in characters $1 \& 3$.

Podperaea krylovii (Podp.) Iwats. et Glime, J. Hattori Bot. Lab. 55: 495. 1984. - Chrysohypnum krylovii Podp., Spisy Prir. Fak Masarykovy Univ. 116, t. 28, f. 19 'krylovi'. 1929. - Campylium krylovii (Podp.) Lazarenko, J. Bot. Acad. Sci. Ukraine 2: 288. 1941. Figs. 35 \& 36

Plants small, green, forming loose mats or growing as solitary shoots among other mosses. Stem prostrate, ca. $1 \mathrm{~cm}$ long, with markedly differentiated hyalodermis, without central strand, irregularly branched, branches 2-4 mm long. Pseudoparaphyllia narrow-lanceolate. Axillar hairs 3-celled, $65 \mu \mathrm{m}$ long, apical cell $25 \times 8 \mu \mathrm{m}$. Stem leaves widely spreading, $0.4-0.8 \times 0.2-$ $0.3 \mathrm{~mm}$, ovate-lanceolate, gradually acuminate, serrate all around, the teeth near the base "double-celled"; costa double or forked, reaching $1 / 4-1 / 2$ the leaf length. Branch leaves 0.4-0.5 $\times 0.1-0.2 \mathrm{~mm}$. Laminal cells $30-55(-75) \times 5(4 / 1) \mu \mathrm{m}$, with papillae on the upper and rarely also the lower ends (Fig. 36-7). Alar cells few, enlarged, indistinctly delimited.
Autoicous. Sporophytes frequent. Perichaetial leaves $0.9 \times 0.2 \mathrm{~mm}$, ecostate, serrulate, smooth. Seta $1.7 \mathrm{~cm}$. Capsule ca. $1 \mathrm{~mm}$ long, arcuate and strongly contacted below the mouth when dry. Operculum conic. Annulus not differentiated. Exostome teeth ca. $0.4 \mathrm{~mm}$ long, abruptly tapered in the transition zone, serrate in the upper third; striolate below; in the middle few plates densely papillose; in the upper part sparsely papillose with small low irregularly arranged papillae; dorsal trabeculae low; ventral trabeculae smooth or with rare spinulose papillae. Endostome $0.5 \mathrm{~mm}$ long, basal membrane $0.2 \mathrm{~mm}$ high; cilia 2-3, nodose. Spores 10-12 $\mu \mathrm{m}$.

Podperaea is easy to recognize by "doublecelled" teeth of leaf margins. Superficially it is similar to Campylium sommerfeltii Myr.

Distribution: The distribution of this species was mapped by Ignatov (1990), but some new information has appeared since that time. The record from Chukotka Peninsula was found to be erroneous (the collection in LE is a mixture of Campylium sommerfeltii and Myurella tenerrima), and also Podperaea have been found in Liaoning Province of China (Buck 23759A, NY!). So, now its range includes South Siberia (westward to Altai), Russian Far East, northern Japan (Hokkaido) and northeastern China. 

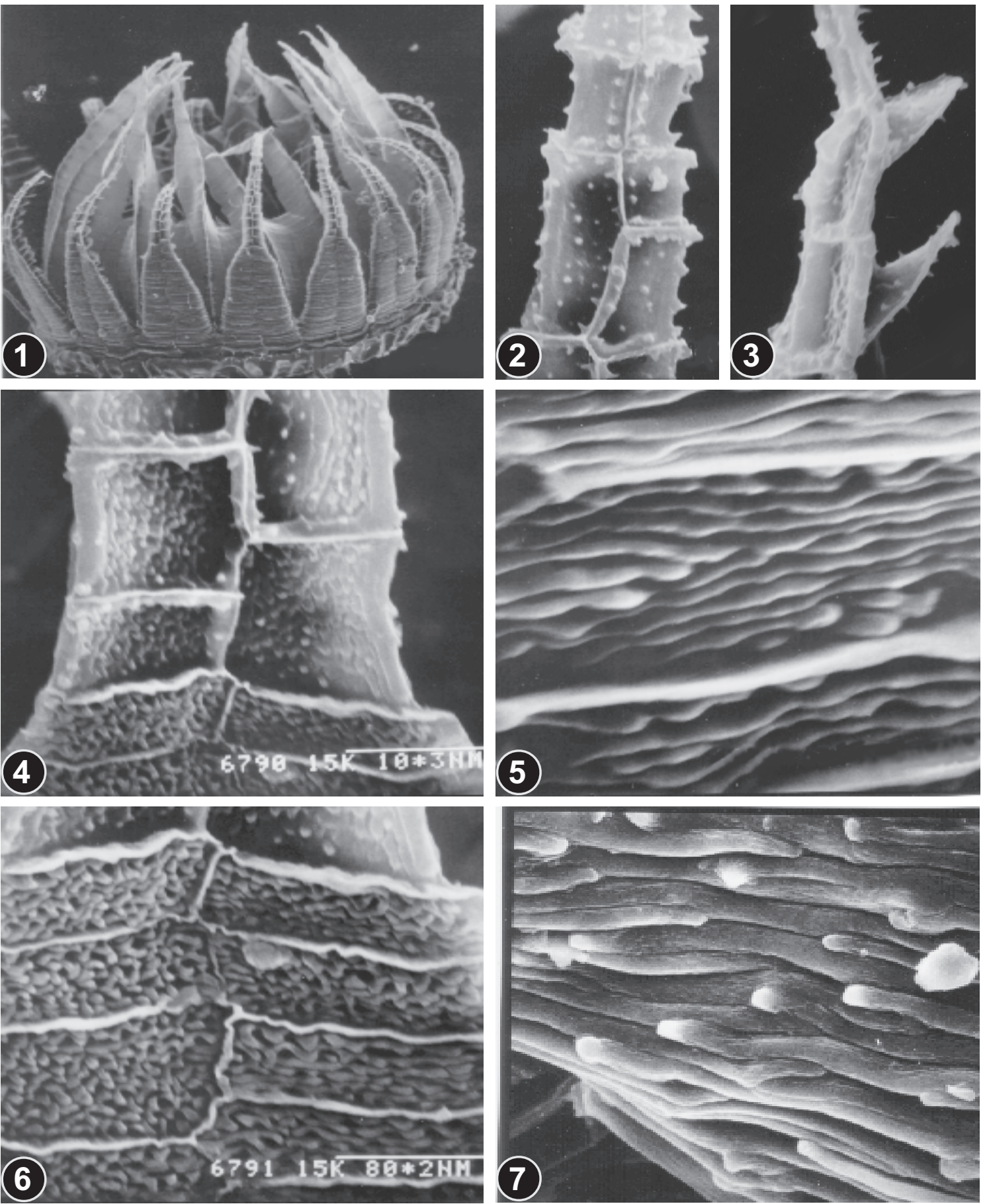

Fig. 36. Podperaea krylovii (Podp.) Iwats. et Glime (from Kobukhta $460 \mathrm{~m}$ Ignatov 0/626): 1 - peristome (230×); 2 - front view of upper part of exostome tooth $(2600 \times)$; 3 - side view of upper part of exostome tooth $(2300 \times)$; $4-$ outer surface of exostome tooth in transition zone $(3400 \times)$; 5 - outer surface of exostome tooth in lower part (11000×); 6 - outer surface of exostome tooth below transition zone $(4300 \times) ; 7$ - surface of stem leaf $(2850 \times)$.

In Altai Podperaea has been found around Teletzkoye Lake, but locally is rather common here. It grows on wet rich soil in ravines, open eroded slopes and occasionally also on rather dry rotten logs.

Specimens examined: Bele $530 \mathrm{~m}(0 / 1192) ;$ Kobukhta $460 \mathrm{~m}$ (0/626); Yailyu $450 \mathrm{~m}(1 / 10 ; 1 / 40 ; 1 / 68), 480 \mathrm{~m}(0 / 1191)$. 


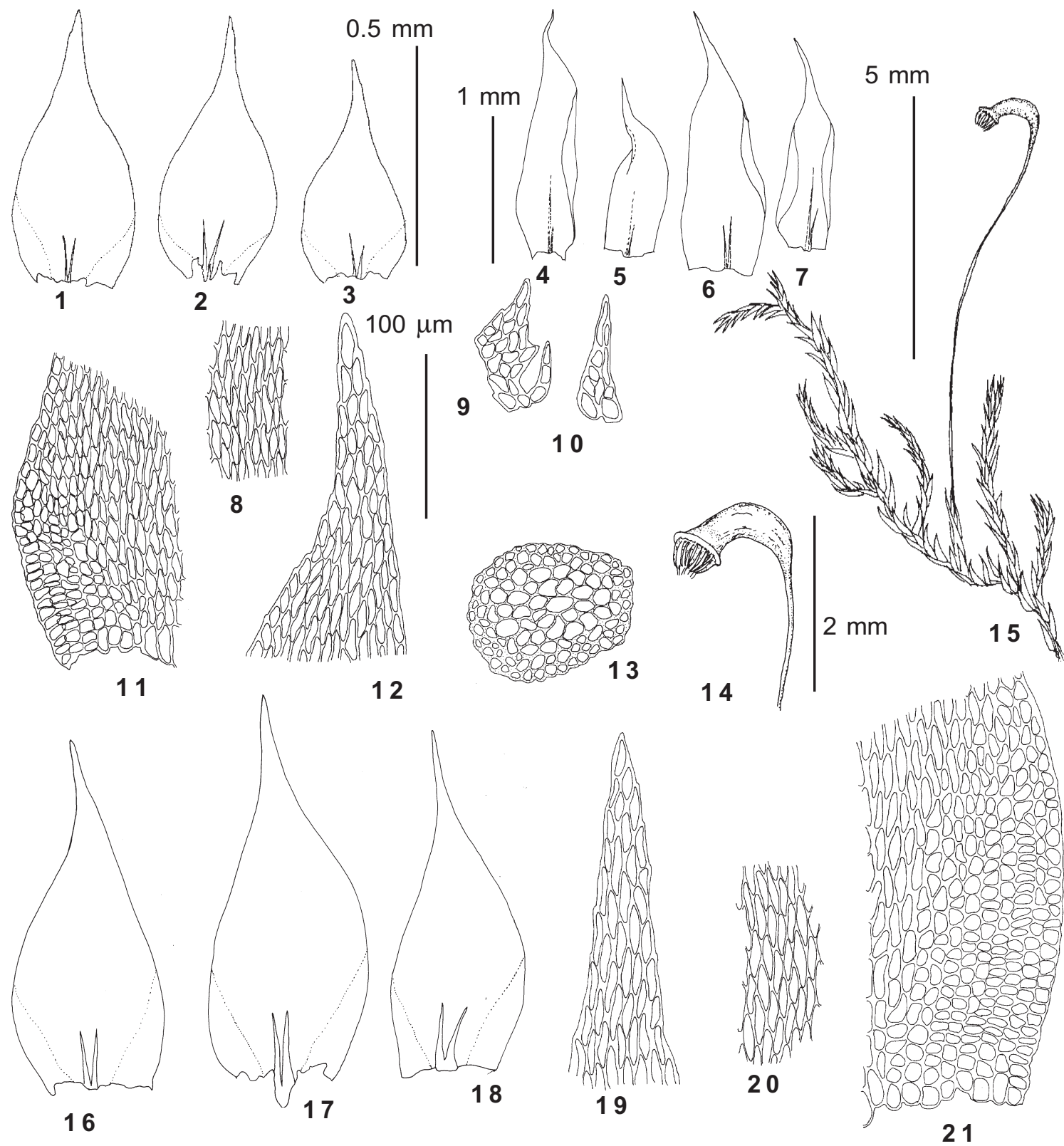

Fig. 37. Homomallium connexum (Card.) Broth. (1-15 - a slender form, from Baigazan $450 \mathrm{~m}$ Ignatov 19/3; 16-21 - a robust form, from Kyrsai $450 \mathrm{~m}$ Bardunov 6.VII.1966): 1-3, 16-18 - leaves; 4-7 - perichaetial leaves; 8, 20 middle laminal cells; 9-10 - pseudoparaphyllia; 11, 21 - alar cells; 12, 19 - upper laminal cells; 13 - stem crosssection; 14 - capsule; 15 - habit. Scale bars: $5 \mathrm{~mm}$ - for $15 ; 2 \mathrm{~mm}$ - for $14 ; 1 \mathrm{~mm}$ - for 4-7; $0.5 \mathrm{~mm} \mathrm{-} \mathrm{for} \mathrm{1-3,} \mathrm{16-}$ $18 ; 100 \mu \mathrm{m}-$ for $8-13,19-21$.

\section{Subfamily Hypnoideae}

The subfamily is characterized by a tendency toward falcate-secund leaves, smooth cells, differentiated alar cells, inclined and \pm curved capsule, and normal hypnoid peristome. However, since the subfamily is large there are exceptions: leaves are straight in Callicladium, Eu- rohypnum, Homomallium, Heterophyllium, and Taxiphyllum; cells are prorate in some Gollania; alar cells are weakly differentiated in Taxiphyllum and some species of Hypnum.

Homomallium (Schimp.) Loeske

The genus has about 10 species, distributed in temperate regions. Brotherus (1925) placed 


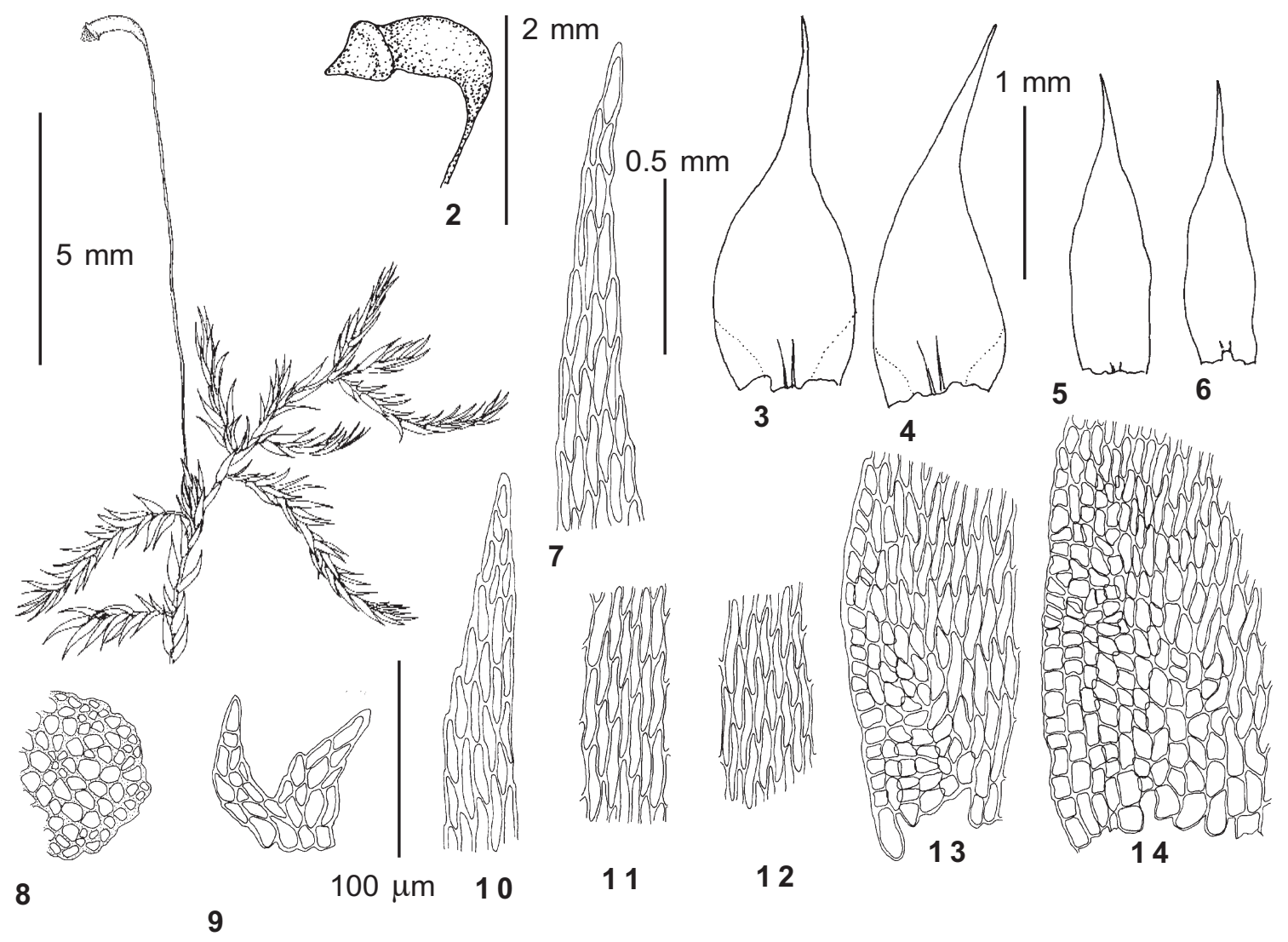

Fig. 38. Homomallium incurvatum (Brid.) Loeske (from Kobukhtushka $440 \mathrm{~m}$ Ignatov 0/634): 1 - habit; 2 capsule; 3-4 - leaves; 5-6 - perichaetial leaves; 7, 10 - upper lamina cells; 8 - stem cross-section; 9 - pseudoparaphyllium; 11-12 - middle lamina cells; 13-14 - alar cells. Scale bars: $5 \mathrm{~mm}$ - for 1; $2 \mathrm{~mm}-$ for 2; $1 \mathrm{~mm}-$ for 5-6; $0.5 \mathrm{~mm}$ - for $3-4 ; 100 \mu \mathrm{m}$ - for $7-14$.

Homomallium into the Pylaisioideae due to straight leaves, without differentiation of stem and branch leaves. However, inclination of capsule and important characters of the peristome of Homomallium are just the same as in Hypnoideae, and Ando (1964) transferred Homomallium in this subfamily. Differences from Hypnum are not many, but about 10 species of Homomallium form a \pm welldelimited group of small autoicous plants with straight leaves whose alar cells are homogeneously subquadrate, forming a distinct area, and capsules relatively long and often distinctly curved when dry. East Asian species of Homomallium were revised by Ando (1964, 1965).

\section{KEY TO THE ALTAIAN SPECIES OF HOMOMALLIUM:}

1. Leaves broadly ovate-lanceolate, \pm shortacuminate; median laminal cells $20-40 \mu \mathrm{m}$ long; alar cells numerous, 20-30 along the margin ............... H. connexum
1. Leaves narrowly ovate-lanceolate, \pm longacuminate; median laminal cells $30-60 \mu \mathrm{m}$ long; alar cells less numerous to few, 10-20 along the margin . .......H. incurvatum

Homomallium connexum (Card.) Broth., Nat. Pfl. 1: 1027. 1908. - Amblystegium connexum Card., Beih. Bot. Centralbl. 17: 39. f.25. 1904. Figs. $37 \& 39(1,3,5)$

Plants small, in green to dark-green mats. Stem ca. $1.5 \mathrm{~cm}$ long, without central strand, irregularly branched; branches to $5 \mathrm{~mm}$ long. Pseudoparaphyllia lanceolate. Axillary hairs 2-celled, $40 \mu \mathrm{m}$ long, apical cell $25 \times 9 \mu \mathrm{m}$. Leaves straight, imbricate, ovate-lanceolate, 0.5-1.0 $\times 0.2-0.4 \mathrm{~mm}$; margins subentire; costa sometimes lacking to double or forked, $1 / 3$ of leaf length. Laminal cells 20-40 ×5-6 (4-5/1) $\mu \mathrm{m}$. Alar cells subquadrate to transverse, 20-30 along the margin.

Autoicous. Sporophytes frequent. Perichaetial leaves 1.5-1.8 $\times 0.5-0.6 \mathrm{~mm}$, costa to $1 / 3-1 / 2$. Seta 1 $\mathrm{cm}$. Capsule ca. 1.5-1.8 mm long, strongly arcuate; 

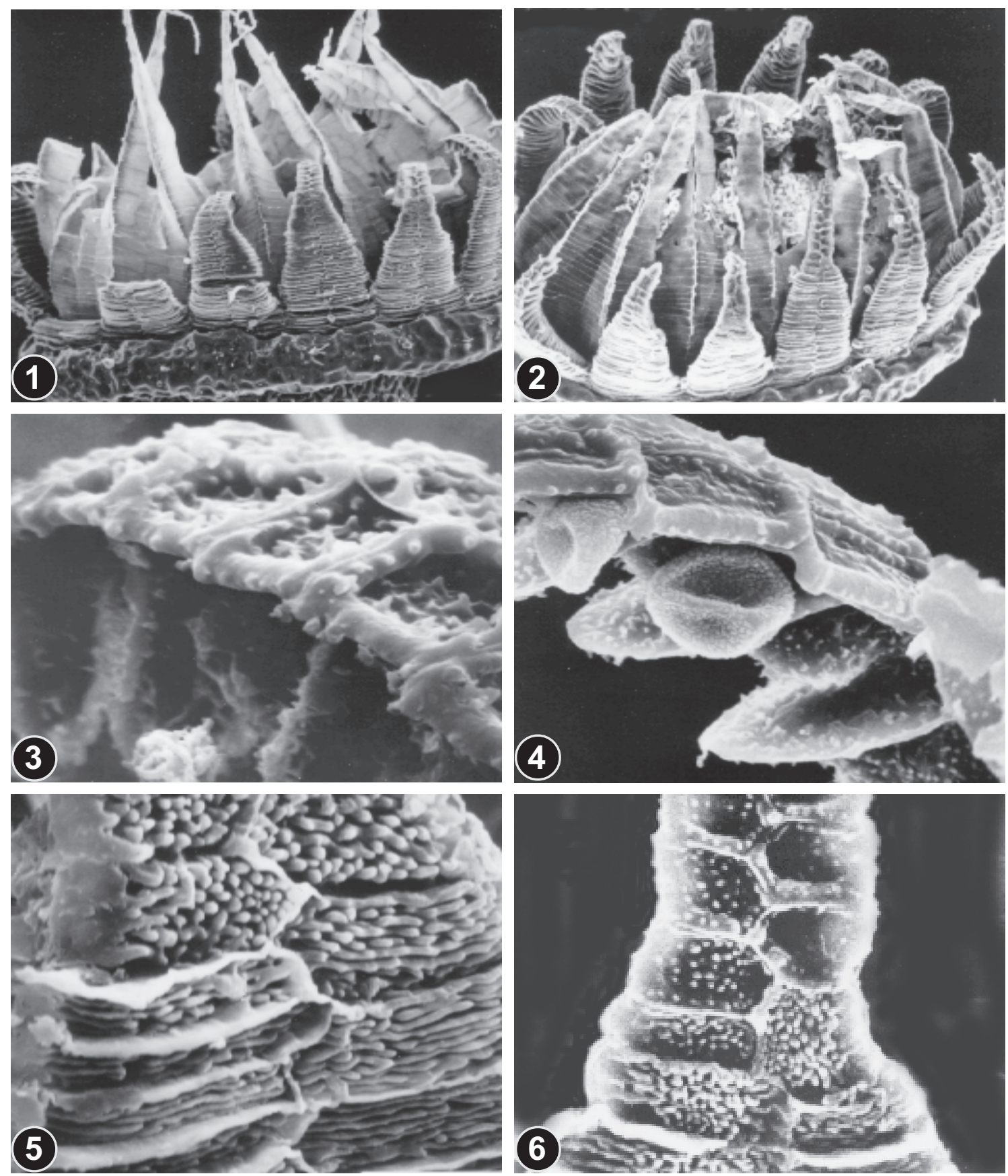

Fig. 39. Homomallium connexum (Card.) Broth. (1, 3, 5, from Baigazan $450 \mathrm{~m}$ Ignatov 19/3) and H. incurvatum (Brid.) Loeske (2, 4, 6, from Ust-Sema $500 \mathrm{~m}$ Ignatov 24/99): 1-2 - peristomes (1 - 230×; 2 - 280×); 3-4 - side views of upper parts of exostome teeth $(3-4250 \times ; 4-3700 \times)$; 5-6 - outer surface of exostome teeth in transition zone $(5-3500 \times ; 6-2600 \times)$.

operculum conic-apiculate. Exostome teeth $0.45 \mathrm{~mm}$ long, abruptly tapered in the transition zone, serrate in the distal third; in the lower part striolate, with perfect cristae; in the middle few plates densely papillose; in the upper part sparsely small-papillose; dorsal trabeculae, incrassate margin, ventral surface and ventral trabeculae with small low papillae. En- dostome as long as teeth, basal membrane, $0.15 \mathrm{~mm}$ high; cilia appendiculate. Spores $12 \mu \mathrm{m}$.

Distribution: This species is known from Japan, Korea, China (most of the provinces), and Russian Far East. In Altai it grows in areas with rather mild climate, on \pm exposed rocks. This is the first record in South Siberia. 


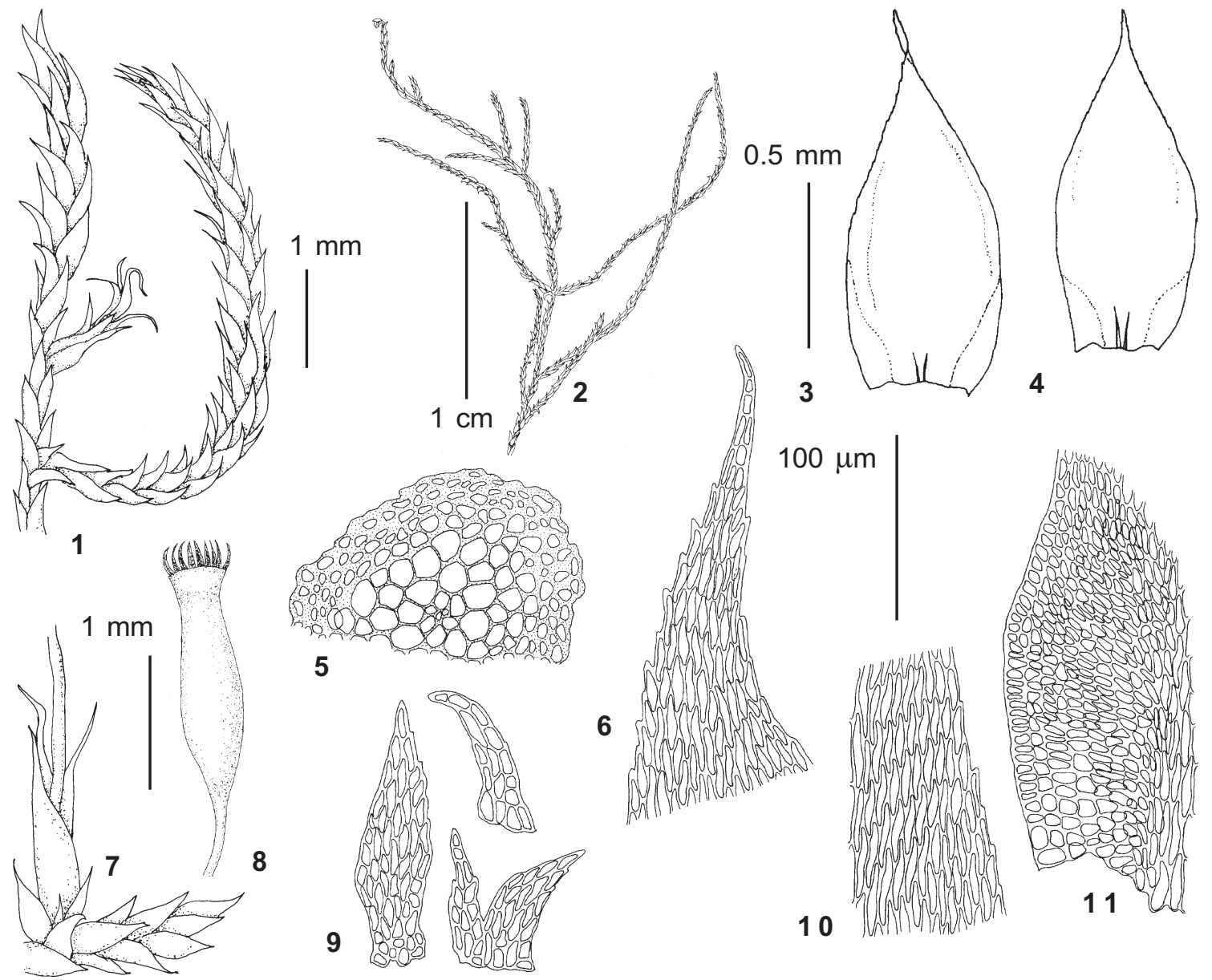

Fig. 40. Eurohypnum leptothallum (C. Müll.) Ando (1, 7-8 - from Chemal $450 \mathrm{~m}$ Ignatov 34/146; 2-6, 9-11 - from Ust-Sema 340 m Ignatov 24/141): 1, 7 - shoots with perichaetia; 2 - habit; 3-4 - leaves; 5 - stem cross-section; 6 - upper laminal cells; 8 - capsule; 9 - pseudoparaphyllia; 10 - middle laminal cells; 11 - alar cells. Scale bars: $1 \mathrm{~cm}$ - for $2 ; 2 \mathrm{~mm}$ - for $8 ; 1 \mathrm{~mm}$ - for 1,$7 ; 0.5 \mathrm{~mm}$ - for 3,$4 ; 100 \mu \mathrm{m}$ - for $5-6,9-11$.

Specimens examined: Baigazan $450 \mathrm{~m}(19 / 3)$; Edikhta Creek $1100 \mathrm{~m}(34 / 164) ;$ Kyrsai $450 \mathrm{~m}$ (Bardunov 6.VII.1966).

Homomallium incurvatum (Brid.) Loeske, Hedwigia 46: 314. 1907. - Hypnum incurvatum Brid., Muscol. Recent. 2(2): 119. 1801.

Figs.38 \& $39(2,4,6)$

Plants small, in dark-green mats. Stem ca. $1.5 \mathrm{~cm}$ long, without central strand, irregularly branched; branches to $4 \mathrm{~mm}$ long. Pseudoparaphyllia lanceolate. Axillary hair 2-celled, $70 \mu \mathrm{m}$ long, apical cell $60 \times 8$ $\mu \mathrm{m}$. Leaves straight, erect, narrowly ovate-lanceolate, 0.6-1.0 $\times 0.2-0.4 \mathrm{~mm}$, lanceolate, margins entire. Laminal cells 30-60 × 4-5 (3-4/1) $\mu \mathrm{m}$. Alar cells 10-20 (-25) along the margin.

Autoicous. Sporophytes frequent. Perichaetial leaves 1.7-1.8 0 0.4-0.5 mm. Seta $1.2 \mathrm{~cm}$. Capsule ca. $2 \mathrm{~mm}$ long, strongly arcuate; operculum conic-apiculate. Exostome teeth $0.55 \mathrm{~mm}$ long, abruptly ta- pered in the transition zone, serrate in the distal third; in the lower part striolate; in the middle few plates densely papillose; in the upper part sparsely roughened with small low and often imperfect papillae; dorsal trabeculae, incrassate margin, ventral surface and ventral trabeculae with small low papillae. Endostome as long as the teeth, basal membrane 0.23 $\mathrm{mm}$ high; cilia appendiculate. Spores $13 \mu \mathrm{m}$.

Homomallium plagiangium C. Müll., described from eastern China, differs from typical $H$. incurvatum in more numerous and more transparent alar cells, and many Altaian specimens fit well in this diagnosis. However, intermediate specimens occur and further study is necessary to understand if this species is really distinct from $H$. incurvatum.

Distribution: Homomallium incurvatum is known from Europe, Ural Mts., Caucasus, Middle 

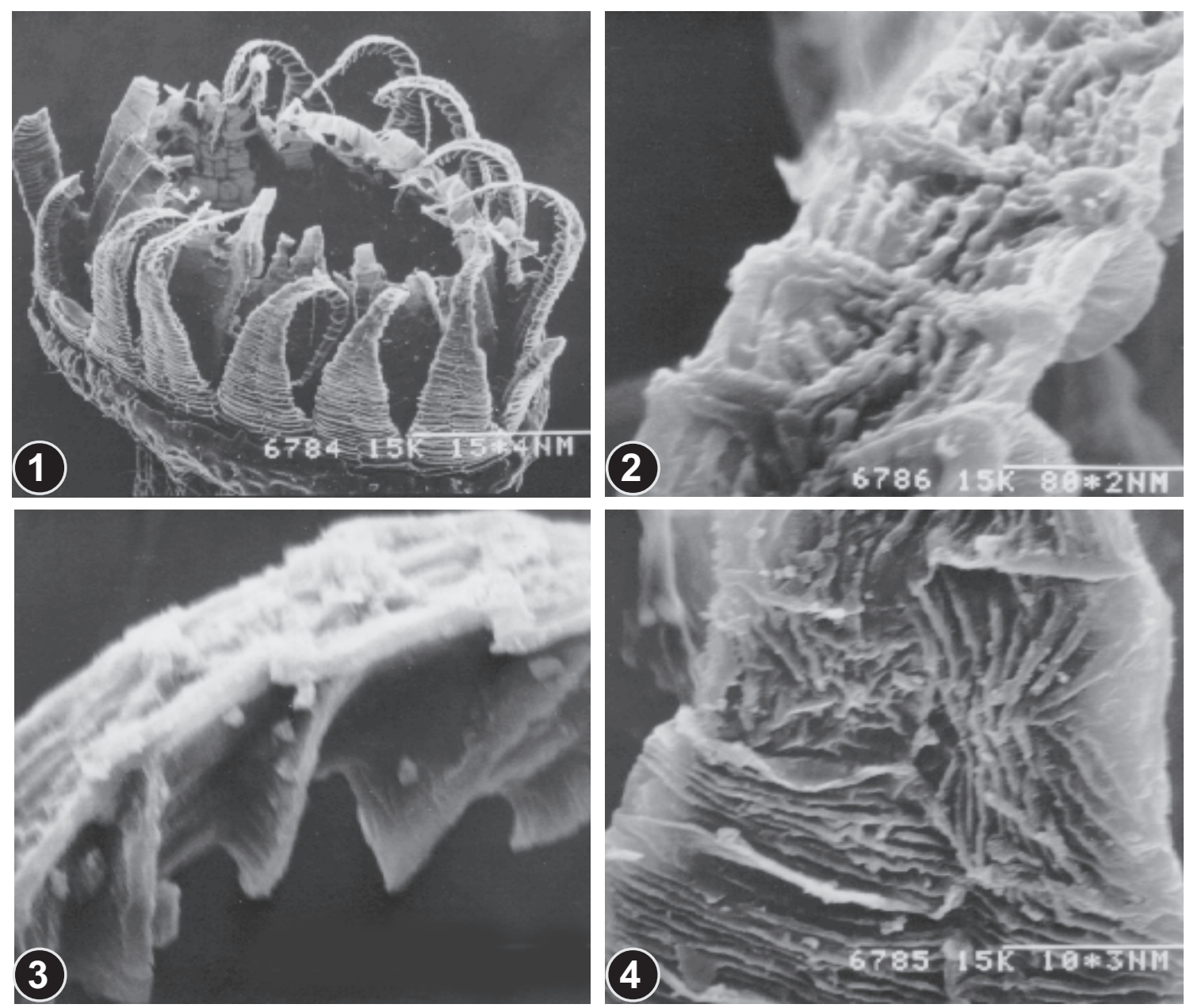

Fig. 41. Eurohypnum leptothallum (C. Müll.) Ando (from Chemal $450 \mathrm{~m}$ Ignatov 34/146): 1 - peristome (220×); 2 - outer surface of exostome tooth in upper part $(4400 \times)$; 3 - side view of exostome tooth in upper part, showing smooth inner trabeclae $(4400 \times)$; 4 - outer surface of exostome tooth in transition zone $(3400 \times)$.

East, Mongolia, China, Japan, and Himalayas. In Altai this species occurs at lower elevations, on diffusely shaded rocks, mostly calcareous.

Specimens examined: Belokurikha $400 \mathrm{~m}$ (Bardunov 5.VI.1966); Bijka Creek, 4 km upstream along Katun 450 m (34/166); Chiri 450 m (17/45); Chiri Creek, $0.5 \mathrm{~km}$ upstream $450 \mathrm{~m}(17 / 88)$; Chulcha River, in middle course $1100 \mathrm{~m}(9 / 44 ; 9 / 67)$; Kobukhta $550 \mathrm{~m}$ (0/2055); Kobukhtushka $440 \mathrm{~m}(0 / 634)$; Kumalyr Verkhnij 1040 m (Krylov 22.VI.1903 LE!); Kumzir 450 m $(20 / 24 ; 20 / 25)$; Kyrsai 450 m (a; Bardunov 6.VII.1966); Ust-Sema $400 \mathrm{~m}$ (24/97), $450 \mathrm{~m}$ (0/1714), $500 \mathrm{~m}(24 / 127 ; 24 / 99)$.

\section{Eurohypnum Ando}

This monotypic genus resembles Homomallium in straight leaves and indistinctly plicate perichaetial leaves, but differs in more robust plants (about the size of Hypnum vaucheri), often irregularly branched, terete foliage; leaves distinctly serrulate above, with extensive alar regions; perichaetial leaves coarsely serrate in acumen; nearly straight to slightly inclined capsule (markedly curved in most of Homomallium, though in H. mexicanum Card. described as variable to suberect, cf. Crum \& Anderson, 1981); and dioicous sexual condition. It is also close to Hypnum, but differs in well-developed, sometimes thick-walled central strand and straight leaves.

Some older publications refer E. leptothallum to Erythrodontium of Entodontaceae, also a \pm julaceous plant, which however has definitely straight capsules and reduced peristome. 
Eurohypnum leptothallum (C. Müll.) Ando, Bot. Mag. Tokyo 79: 761. 1966. - Cupressina leptothalla C. Müll., Nuov. Giorn. Bot. Ital., n. s., 3: 119. 1896. - Hypnum leptothallum (C. Müll.) Par., Ind. Bryol. Suppl.: 204. 1900. - E. leptothallum f. tereticaule Nog., J. Jap. Bot. 15: 760. 1939.

Figs. $40 \& 41$

Plants medium-sized, green to brown-green. Stem prostrate, $3 \mathrm{~cm}$ long, without hyalodermous, with central strand; branching strongly depends on light conditions: in shade, shoots slender, prostrate and very rarely irregularly branched, while in sunny places, regularly (though not densely) pinnate-branched, more stiff, sometimes tumid. Pseudoparaphyllia narrow lanceolate. Axillary hairs 8-celled, 170-200 $\mu \mathrm{m}$ long, apical cell ca. $40 \times 10 \mu \mathrm{m}$. Stem leaves straight to somewhat falcate above, $1.0-1.2(-1.5) \times 0.4-0.5$ $(-0.7) \mathrm{mm}$, ovate, acuminate; margins serrate above, entire below. Laminal cells 35-55 × 5-6(3-4/2) $\mu \mathrm{m}$. Alar cells subquadrate to transversely ovate, forming an indistinctly delimited large group, ca. 25-30 cells along the margin.

Dioicous. Sporophytes found in Altai in only one collection (calcareous rocks on steep slope to the Katun River, in diffuse shade of scattered pines; forest-steppe zone). Perichaetial leaves $3 \mathrm{~mm}$ long, indistinctly plicate, strongly serrate above; costa short and double, to $1 / 3$ the leaf length. Seta $1.5 \mathrm{~cm}$. Capsule ca. $1.5 \mathrm{~mm}$ long. Exostome teeth $0.5 \mathrm{~mm}$ long, gradually narrowed, slightly serrulate above; striolate (cristae smooth) below; in the middle cristae changing orientation to oblique and longitudinal; in the upper part longitudinally striolate with cristae low-papillose; dorsal trabeculae low, with margin slightly incrassate; ventral surface and trabeculae smooth. Endostome $0.55 \mathrm{~mm}$ long, basal membrane $0.2 \mathrm{~mm}$ high; cilia nodose or reduced. Spores $15 \mu \mathrm{m}$.

Eurohypnum is similar to Hypnum vaucheri in numerous alar cells and concave leaves, but differs from it by leaves straight and clearly serrulate to serrate above.

Distribution: The species is common in many regions of Japan, Korea, China, Taiwan, Mongolia, Russian Far East and South Siberia. In Altai Eurohypnum is common in \pm dry habitats within the forest and forest-steppe zones, growing mostly on rocks, very rarely on Populus trunks.

Specimens examined: Aedigan Creek, $5 \mathrm{~km}$ upstream 600 m (34/129; 34/43); Artyshtu Creek 600 m (Zolotukhin 20.IX.1989), 650 m (Zolotukhin 20.IX.1989); Arzhan (Chulyshman lower course) $530 \mathrm{~m}$ (Zolotukhin \& al. 24.IV.1978); Chemal $450 \mathrm{~m}(29 / 46)$; Chemal, $10 \mathrm{~km}$ upstream along Katun $450 \mathrm{~m}(34 / 146 ; 34 / 30)$; Chiri $450 \mathrm{~m}(0 / 1194 ; 0 / 2020 ; 17 / 63 ; 17 / 92)$; Chiri Creek,

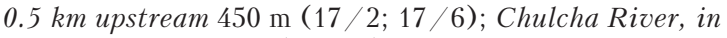
middle course $820 \mathrm{~m}$ (0/633); Chulyshman River, $5 \mathrm{~km}$ upstream $750 \mathrm{~m}$ (Zolotukhin \& al. 26.IV.1978); Derbogach $450 \mathrm{~m}(0 / 24 ; 0 / 4)$; Kuba Creek, $5 \mathrm{~km}$ apart from Chemal 500 m (Makarov 3.VI.1972); Maima 280 m (35/50; $35 / 51 ; 35 / 52), 350 \mathrm{~m}(35 / 9)$; Malyi Yaloman $900 \mathrm{~m}$ (25/143), 950 m (25/73); Malyi Yaloman Creek, 4 km upstream $900 \mathrm{~m}$ (25/67); Ust-Sema $340 \mathrm{~m}$ (24/141), 350 m (24/139), $450 \mathrm{~m}(24 / 50), 500 \mathrm{~m}(0 / 1193)$; Yailyu $450 \mathrm{~m}(1 / 30 ; 1 / 4)$.

Hypnum Hedw.

A large genus with about 60 species, distributed in all zones of both hemispheres. The main diagnostic characters include regularly pinnate plants, falcate-secund leaves with short double costa, curved to arcuate capsule, and perfect peristome. Subdivision of the genus into $11 \mathrm{sec}-$ tions was suggested by Ando (1973), of which the monotypic section Polyptera was later segregated as a new genus Caribaeohypnum (Ando \& Higuchi, 1984). Two other sections are sometimes considered as separate genera, Pseudostereodon and Breidleria.

Key to THE Altaian SPECIES OF HYPNUM

1. Epidermal cells of stem large, \pm thin-walled .............................. 2

1. Epidermal cells of stem not differentiated, thick-walled ................... 5

2. Plants large (stem leaves 0.7-0.9 mm wide) ............ pratense (p. 85)

2. Plants small to medium-sized (stem leaves 0.3-0.6(0.7) $\mathrm{mm}$ wide) . . . . . . . . 3

3. Plants medium-sized, autoicous, usually with sporophytes; epidermal cells weakly differentiated ............. H. fauriei (p. 80)

3. Plants small-sized; dioicous, only rarely with sporophytes; epidermal cells clearly differentiated ..................... 4

4. Stem leaves triangular-lanceolate, clearly rounded towards the cordate base; shoots julaceous to complanate; margins plane; plants densely plumose-branched ................ H. plicatulum (p. 85)

4. Stem leaves ovate-lanceolate, weakly narrowed to the insertion; margins sometimes recurved below and incurved in transition to acumen, so the upper part is tubulose; shoots clearly julaceous; plants regularly to \pm irregularly branched ................ H. hamulosum (p. 83)

5. Stems regularly pinnate-branched; plants autoicous, usually bearing sporophytes . . 6 


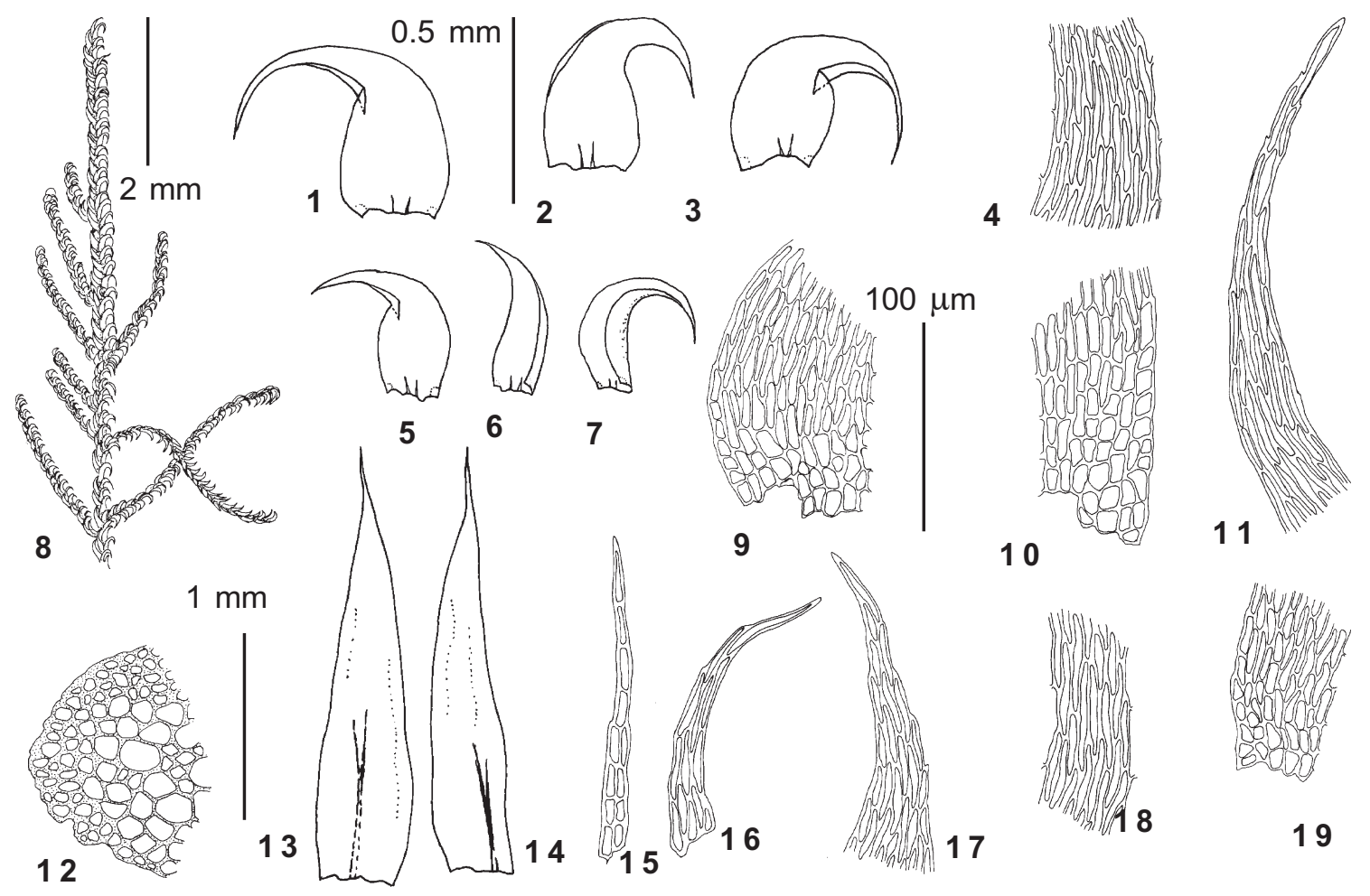

Fig. 42. Hypnum recurvatum (Lindb. \& H. Arnell) Kindb. (from Bayas Lake $1860 \mathrm{~m}$ Ignatov 0/1722): 1-3 - stem leaves; 4 - middle laminal cells of stem leaf; 5-7 - branch leaves; 8 - habit; 9-10 - alar cells of stem leaf; 11 - upper laminal cells of stem leaf; 12 - stem cross-section; 13-14 - perichaetial leaves; 15-16 - pseudoparaphyllia; 17 - upper laminal cells of branch leaf; 18 - middle laminal cells of branch leaf; 19 - alar cells of branch leaf. Scale bars: 2 mm - for $8 ; 1 \mathrm{~mm}$ - for $13-14 ; 0.5 \mathrm{~mm}$ - for $1-3,5-7 ; 100 \mu \mathrm{m}$ - for $4,9-12,15-19$.

5. Stems regularly to irregularly pinnatebranched; plants dioicous (never observed with sporophytes in Altai) ......... 8

6. Plants small; leaves serrulate; alar cell groups small and indistinct; pseudoparaphyllia subulate numerous and conspicous around branch initials; rare alpine epilithic species ........ H. recurvatum (p. 00)

6. Plants small to medium-sized; alar cell groups rather distinct; pseudoparaphyllia short and less numerous, not conspicous; common epixylic species . . . . 7

7. Plants small-sized, leaves serrate to serrate; alar cells rather homogeneous .................. pallescens (p. 71)

7. Plants medium-sized, leaves serrulate; alar cells heterogeneous .... H. fauriei (p. 80)

8. Leaves plicate, margins strongly revolute .................. revolutum (p. 74)

8. Leaves not plicate, margins erect or weakly recurved below . . . . . . . . . . 9
9. Stem leaves cordate-auriculate; large densely and regularly pinnate alpine plants .................. H. procerrimum (p. 79)

9. Leaves otherwise . ............. 10 10a. Large brownish alpine plants; leaves markedly falcate; alar cells dark-brown, thick-walled, forming an excavate group; laminal cells thick-walled and porose, elongate (8-10:1); pseudoparaphyllia broadly ovate ... H. bambergeri (p. 79) 10b. Medium-sized to large plants; leaves weakly falcate to nearly straight; alar cells form a \pm well delimited square group; laminal cells rarely porose, elongate (about 8-10:1); pseudoparaphyllia subfilamentose to lanceolate . . H. cupressiforme (p. 76)

10c. Medium-sized plants; leaves concave, \pm abruptly acuminate, usually falcate; alar cells numerous, forming a less delimited group; laminal cells not porose, relatively short and wide (about 1:4-7); pseudoparaphyllia ovate ....... . vaucheri (p. 75) 

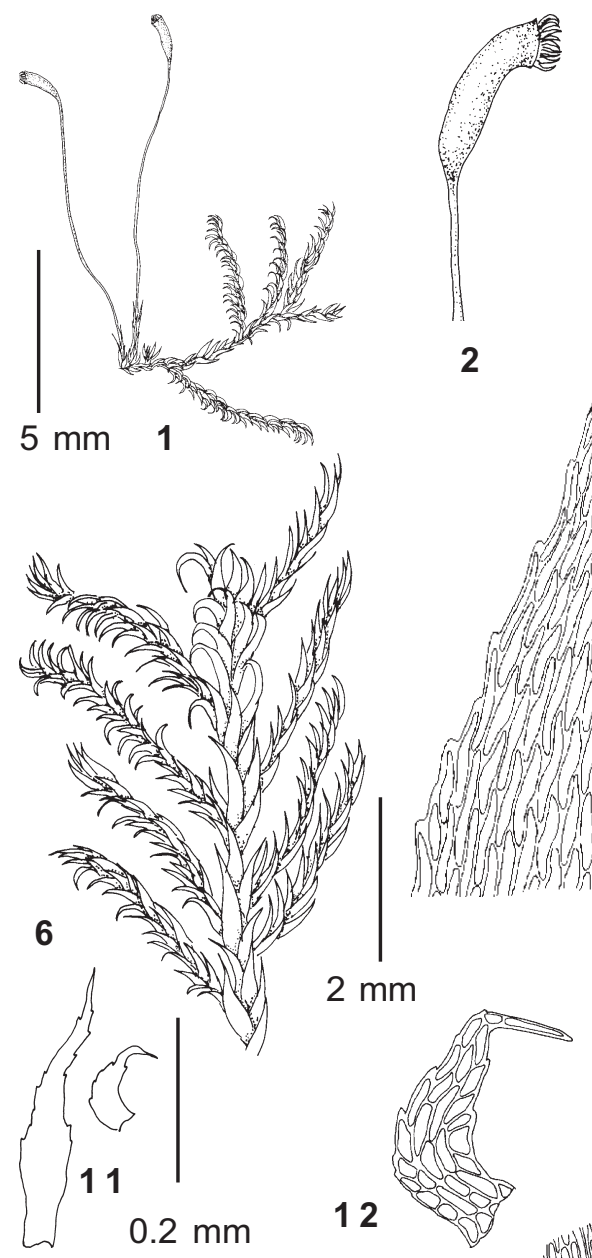

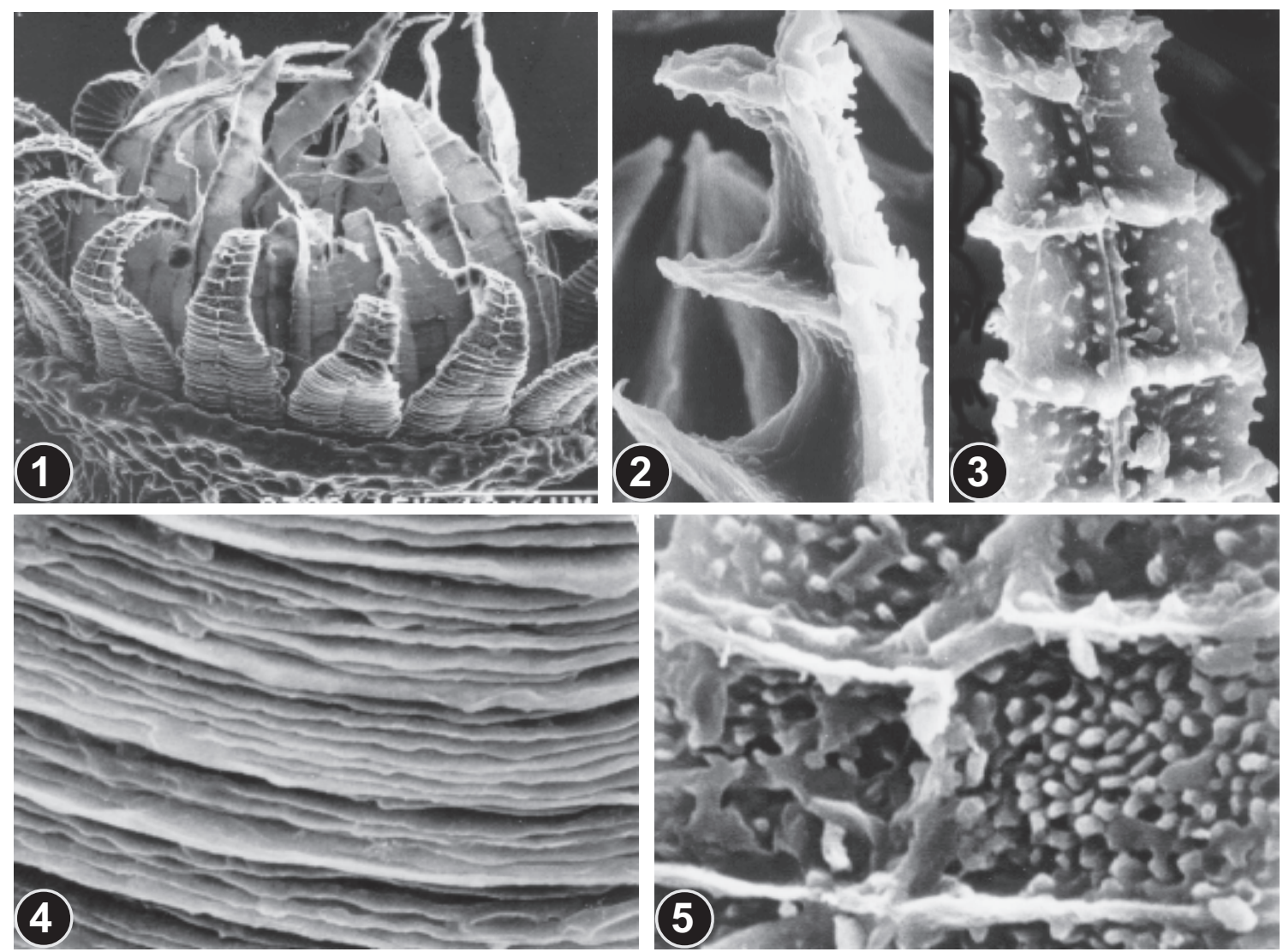

Fig. 44. Hypnum pallescens (Hedw.) P. Beauv. (from Klyk Pass $700 \mathrm{~m}$ Ignatov 0/1718): 1 - peristome (290×); 2 - side view of exostome tooth in upper part $(3000 \times)$; 3 - front view of exostome tooth in upper part (2500×); $4-$ outer surface of exostome tooth in lower part $(5750 \times) ; 5$ - outer surface of exostome tooth in transition zone $(4300 \times)$.

Hypnum recurvatum (Lindb. \& H. Arnell) Kindb., Enum. Bryin. Exot. Suppl. 2: 100. 1891. - Stereodon recurvatus Lindb. et $\mathrm{H}$. Arnell, Kongl. Sv. Vet. Akad. Handl. 23(10): 149. 1890.

Fig. 42

Plants small, in dense yellow-green tufts. Stem prostrate, to $2 \mathrm{~cm}$ long; epidermal cells non-differentiated; central strand weak; regularly branched; branches 4 $\mathrm{mm}$ long. Pseudoparaphyllia subulate to filamentose, numerous around branch primordia. Axillary hairs 34-celled, 30-80 $\mu \mathrm{m}$ long, apical cell 20-40×6 $\mu \mathrm{m}$. Stem leaves falcate, $0.6-0.8 \times 0.2-0.3 \mathrm{~mm}$, ovate-lanceolate; margins recurved below, serrulate. Branch leaves $0.4-$ $0.6 \times 0.1-0.2 \mathrm{~mm}$. Laminal cells 35-50 × 4-5 (3-4/11.5) $\mu \mathrm{m}$. Alar cells few, weakly differentiated.

Autoicous. Sporophytes (old and imperfect) present in a single Altaian collection (exostome description in part made using European material). Perichaetial leaves erect, $2.2 \times 0.8 \mathrm{~mm}$, oblong-lanceolate, shortly acuminate, plicate, costa reaching about $2 / 3$ the leaf length, margins entire. Seta 1.2 cm. Capsule ca. $1.2 \mathrm{~mm}$ long. Exostome teeth ca. 0.4 $\mathrm{mm}$ long, gradually tapered, nearly entire; striolate below; in the middle densely papillose on many plates; in the upper part very rarely papillose with small irregularly arranged papillae, with prominent dorsal trabeculae and incrassate margin; ventral surface and trabeculae smooth or with low irregular papillae. Spores ca. $10 \mu \mathrm{m}$.

Distribution: Hypnum recurvatum has a scattered distribution in mountains of Central and Northern Europe, Caucasus, Siberia (both southern and northern), Mongolia, Greenland, and North America. In Altai it was found only once in the subalpine zone, on rock outcrops.

Specimen examined: Bayas Lake $1860 \mathrm{~m}$ (0/1722).

Hypnum pallescens (Hedw.) P. Beauv., Prodr. Aetheogam. 67. 1805. - Leskea pallescens Hedw., Sp. Musc. 219. t. 55, f. 1-6. 1801. - Hypnum reptile Michx., Fl. Bor. Am. 2: 315. 1803.

Figs. 43 \& 44

Plants small, in dense dark-green to brownish dull tufts. Stem prostrate, to $6 \mathrm{~cm}$ long; regularly pinnate-branched; branches 4-5 mm long. Epider- 


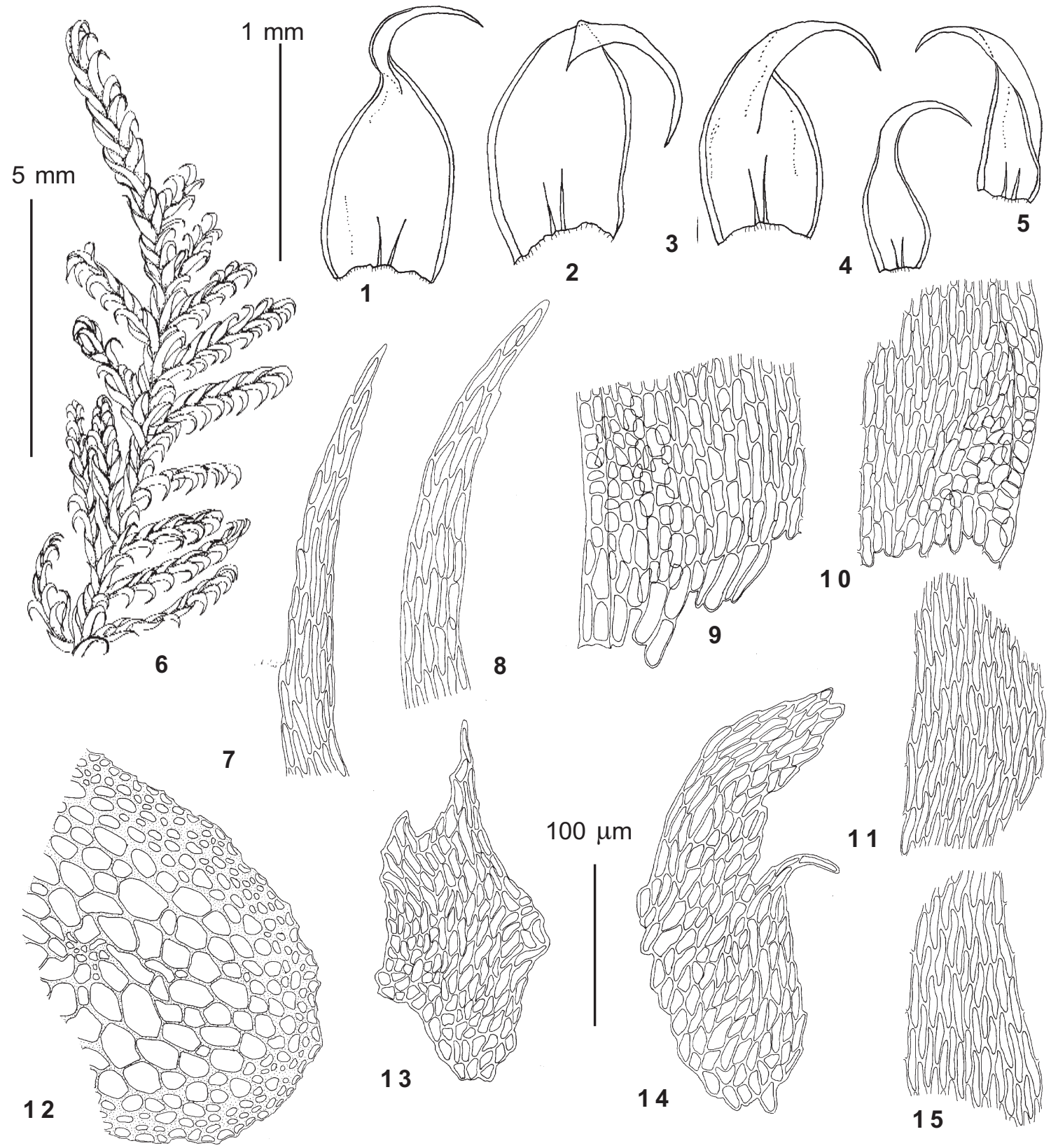

Fig. 45. Hypnum revolutum (Mitt.) Lindb. (from Kukol 2400 m Ignatov 0/617): 1-3 - stem leaves; 4-5 - branch leaves; 6 - habit; 7 - upper laminal cells of stem leaf; 8 - upper laminal cells of branch leaf; 9 - alar cells of stem leaf; 10 - alar cells of branch leaf; 11 - middle laminal cells of stem leaf; 12 - stem cross-section; 13-14 - pseudoparaphyllia; 15 - middle laminal cells of branch leaf. Scale bars: $5 \mathrm{~mm}$ - for $6 ; 1 \mathrm{~mm}$ - for 1-5; $100 \mu \mathrm{m}-$ for 7-15.

mal cells not enlarged. Pseudoparaphyllia lanceolate to subulate, often short. Axillary hairs 3-celled, ca. 70 $\mu \mathrm{m}$, apical cell 30-40 $\times 5-6 \mu \mathrm{m}$. Stem leaves falcatesecund, 1.0-1.6 × 0.4-0.6 mm, gradually tapered in long narrow acumen, at base somewhat rounded; margins distinctly to weakly serrulate throughout, sometimes recurved below. Branch leaves $0.8-0.9 \times$ 0.2-0.3 mm. Laminal cells 35-55(-60) $\times 6(5 / 1) \mu \mathrm{m}$.
In alar regions cells subquadrate, forming a large indistinctly delimited group.

Autoicous. Inner perichaetial leaves 1.8-2.5 $\times 0.5$ $0.6 \mathrm{~mm}$, plicate, with indistinct double costa. Seta 0.8-1.2 cm. Capsule 1.3-1.5 mm long, arcuate, palebrown. Operculum long-rostrate. Exostome teeth 0.38 $\mathrm{mm}$ long, gradually tapered, serrulate in the upper part; in the lower part striolate, with cristae some- 

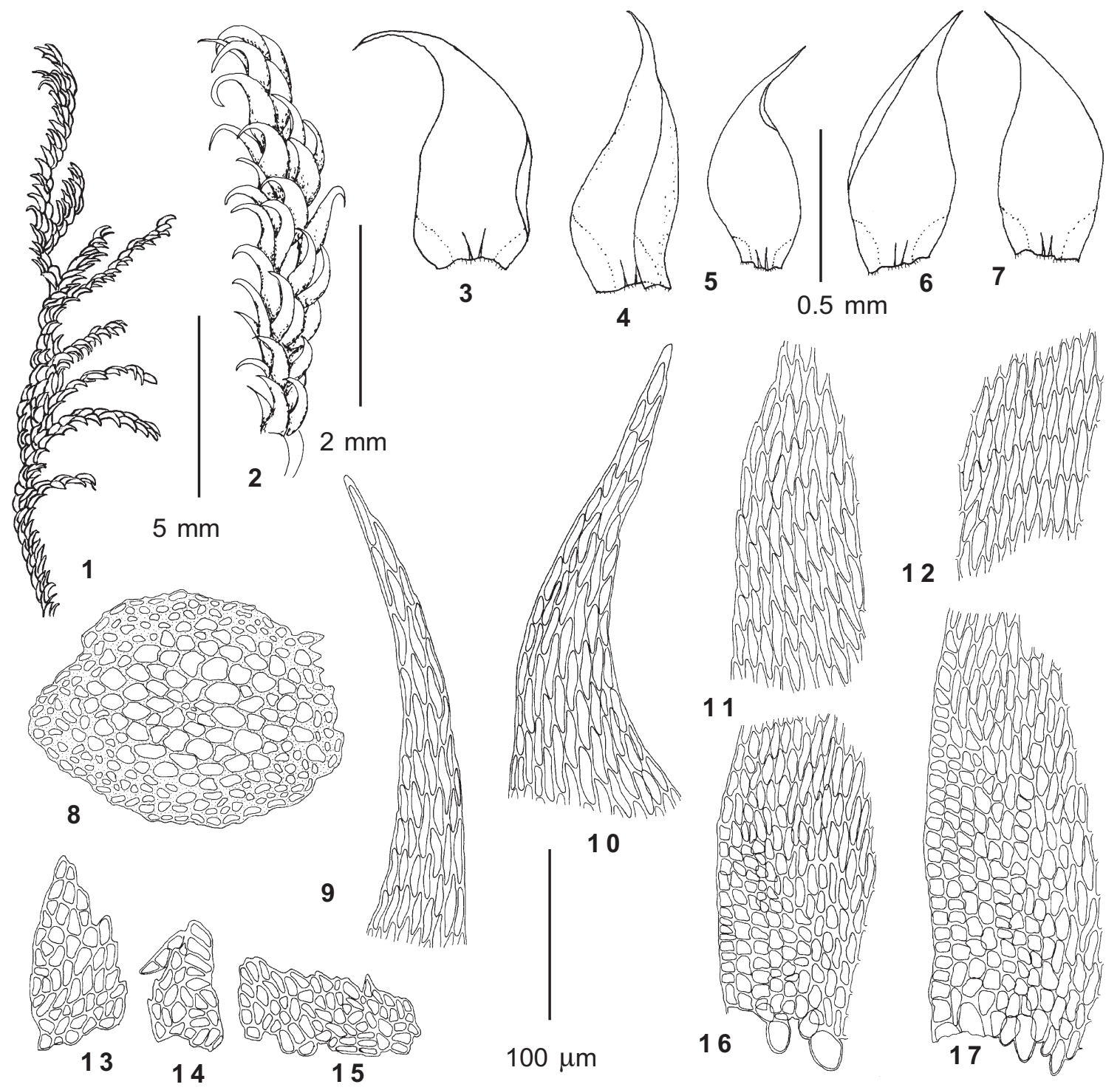

Fig. 46. Hypnum vaucheri Lesq. (from Ulagan 1220 m Ignatov 36/236): 1-2 - habit; 3-5 - stem leaves; 6-7 - branch leaves; 8 - stem cross-section; 9 - upper laminal cells of stem leaf; 10 - upper laminal cells of branch leaf; 11 - middle laminal cells of branch leaf; 12 - middle laminal cells of stem leaf; 13-15 - pseudoparaphyllia; 16 - alar cells of branch leaf; 17 - alar cells of stem leaf. Scale bars: $5 \mathrm{~mm}$ - for 1; $2 \mathrm{~mm}$ - for 2; $0.5 \mathrm{~mm}$ - for 3-7; $100 \mu \mathrm{m}-$ for 8-17.

what wavy; in the middle densely papillose on many plates; in the upper part with scattered low papillae; dorsal lamelalle low to medium and more papillose, margin non-incrassate; ventral surface and trabeculae smooth or with rare low papillae. Endostome to $0.4 \mathrm{~mm}$ long, basal membrane $0.15 \mathrm{~mm}$ high; cilia nodose. Spores $12-15 \mu \mathrm{m}$.

Distribution: Widespread and common in southern part of the boreal and northern parts of the temperate zone throughout the Holarctic. In Altai it is common on trunks, stumps and logs in forest of at lower elevations, with very few findings in the taiga zone.

Specimens examined: Ayukol $1000 \mathrm{~m}(0 / 1701)$; Bayas Creek, in middle course $850 \mathrm{~m}(16 / 6)$; Bolshoi Shaltan Creek $540 \mathrm{~m}(0 / 1717)$; Gorno-Altaisk $400 \mathrm{~m}$ (35/ 37); Kairu Creek, 8 km upstream 1000 m (15/116a; $15 /$ 51); Karakol Lakes 1800 m (26/116); Kayakkatuyarykskij Creek $1950 \mathrm{~m}(3 / 64)$; Kishte $440 \mathrm{~m}$ (Zolotukhin 11.VII.1988); Klyk Pass 700 m (0/1718); Kobukhtushka $440 \mathrm{~m}$ (Zolotukhina 13.VII.1988); Korbu $440 \mathrm{~m}$ (Zolotukhin 20.X.1988); Srednij Shaltan Creek $640 \mathrm{~m}$ (0/ 611); Tura Creek, in middle course $1300 \mathrm{~m}(28 / 26 ; 28$ 48a; 28/50); Yailyu $450 \mathrm{~m}(0 / 1709), 480 \mathrm{~m}(0 / 628)$, $500 \mathrm{~m}(0 / 1716), 600 \mathrm{~m}(0 / 1715)$. 


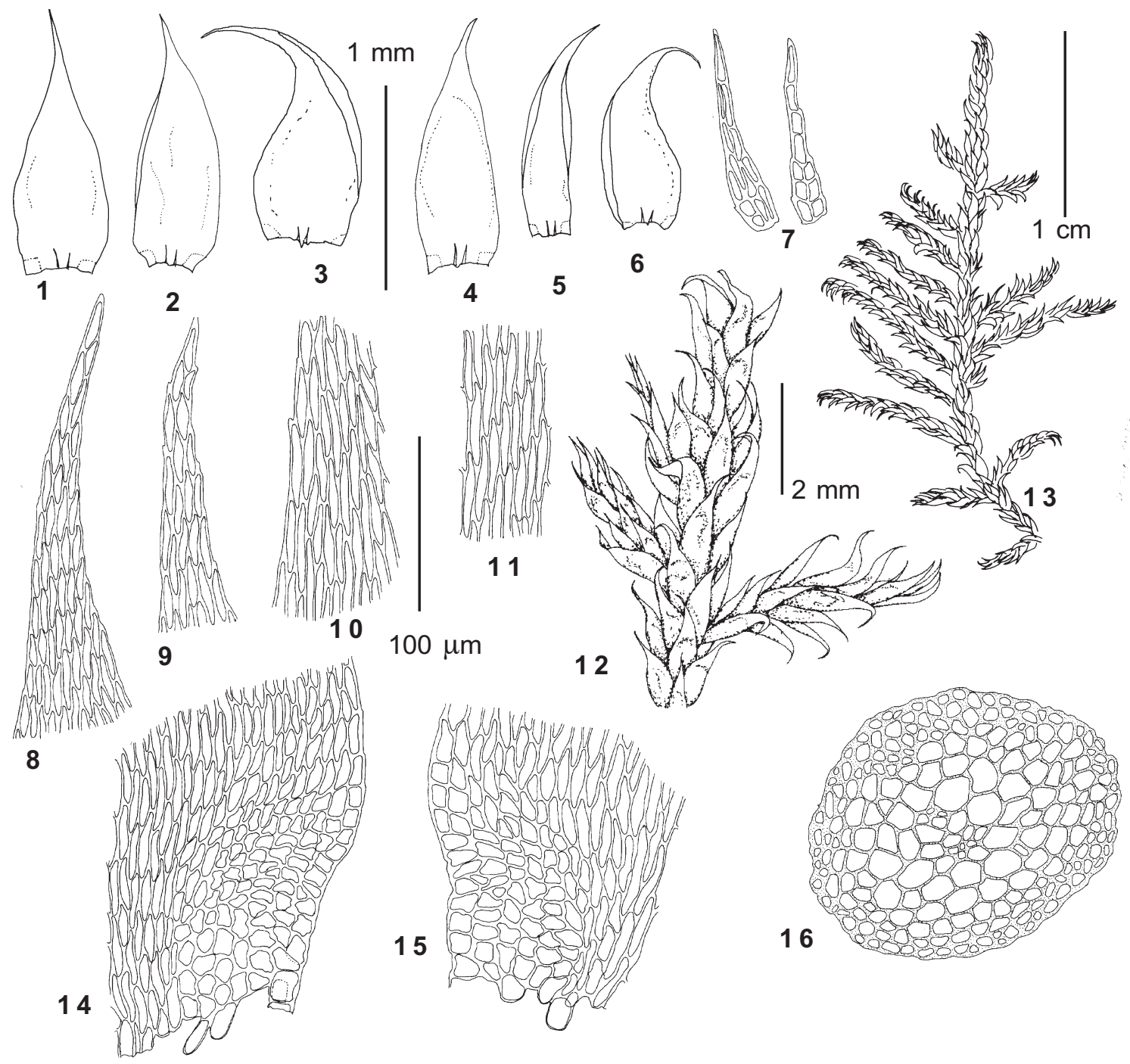

Fig. 47. Hypnum cupressiforme Hedw. var. cupressiforme (a rather slender form, from Chulcha River, in middle course 1000 m Ignatov 9/156): 1-3 - stem leaves; 4-6 - branch leaves; 7 - pseudoparaphyllia; 8 - upper laminal cells of stem leaf; 9 - upper laminal cells of branch leaves; 10 - middle laminal cells of stem leaf; 11 - middle laminal cells of branch leaf; 12-13 - habit; 14 - alar cells of stem leaf; 15 - alar cells of branch leaf; 16 - stem cross-section. Scale bars: $1 \mathrm{~cm}$ - for $13 ; 2 \mathrm{~mm}$ - for $12 ; 1 \mathrm{~mm}$ - for $1-6 ; 100 \mu \mathrm{m}$ - for $7-11,14-16$.

Hypnum revolutum (Mitt.) Lindb., Oefv. Foerh. Kongl. Sv. Vet.-Akad. 23: 542. (1866) 1867. - Stereodon revolutus Mitt., J. Proc. Linn. Soc., Bot. Suppl. 1: 97.1859.

Fig. 45

Plants small to medium-sized, yellow-green to golden-brownish mats. Stem prostrate to suberect, to $3 \mathrm{~cm}$ long; epidermal cells not enlarged, but outer wall \pm thin; central strand weak; regularly pinnate-branched, branches to $8 \mathrm{~mm}$ long. Pseudoparaphyllia short, ovate to lanceolate. Axillary hairs 3-4-celled, 60-90 $\mu \mathrm{m}$ long, apical cell 30-60 × $10 \mu \mathrm{m}$. Stem leaves crowded, falcatesecund, 1.4-1.8 $\times 0.5-0.6 \mathrm{~mm}$, more or less plicate; margins revolute nearly throughout, entire to slightly ser- rulate above. Branch leaves 1.0-1.2 $\times$ 0.3-0.4. Laminal cells 30-45 × 5-6 (4-5/1) $\mu \mathrm{m}$. Alar subquadrate cells form a rectangular group, ca. 10 cells long, 4-5 cells wide. Dioicous. Sporophytes not found in Altai.

Distribution: This species is widespread in the Arctic and in the alpine zone of most of the Holarctic mountains. It has also several localities in the Southern Hemisphere. In Altai it grows on rocks in the alpine and subalpine belts.

Specimens examined: Kairu-Bazhi Peak 2300 m (13/ 131); Kobiguayuk Creek 2300 m (0/199; 0/616); Kukol $2400 \mathrm{~m}$ (0/617); Tabozhok Peak $2350 \mathrm{~m}$ (31/320), 2700 m (31/308; 31/309), 2750 m (31/311); Yakhansoru Lake $2000 \mathrm{~m}$ (Zolotukhin 26.VI.1990). 

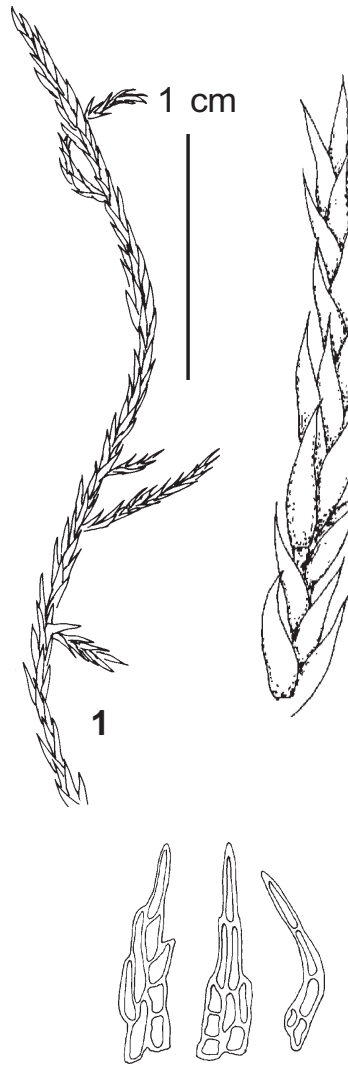

12

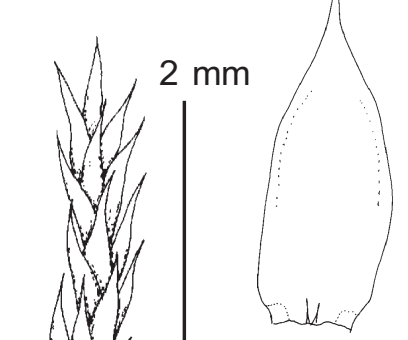

3

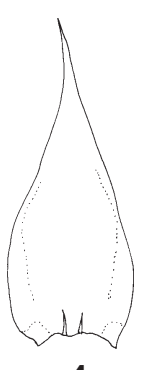

4

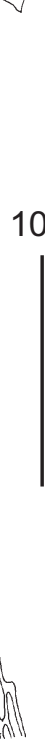

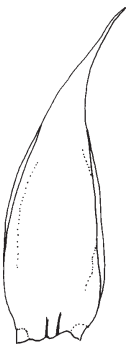

5
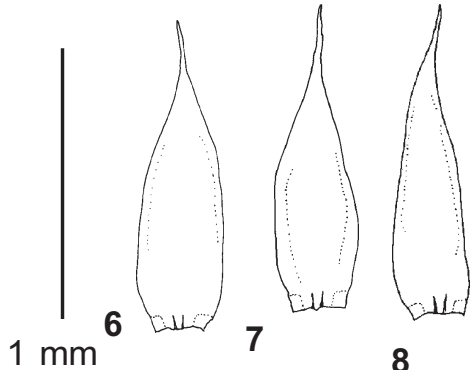

7

8

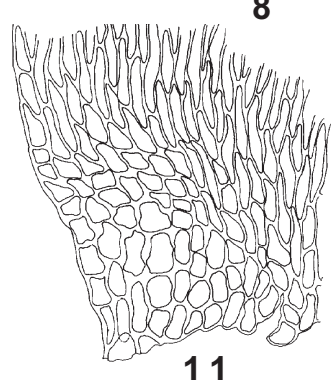

11

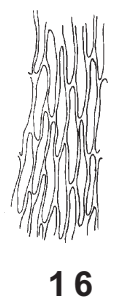

Fig. 48. Hypnum cupressiforme var. filiforme Brid. (from Kayakkatuyarykskij Creek $1850 \mathrm{~m}$ Ignatov 8/156): 1-2 habit; 3-5 - stem leaves; 6-8 - branch leaves; 9 - stem cross-section; 10 - middle laminal cells of branch leaf; 11 alar cells of stem leaf; 12 - pseudoparaphyllia; 3 - upper laminal cells of branch leaf; 14 - upper laminal cells of stem leaf; 15 - alar cells of branch leaf; 16 - middle laminal cells of branch leaf. Scale bars: $1 \mathrm{~cm}-$ for $1 ; 2 \mathrm{~mm}-$ for 2 ; $1 \mathrm{~mm}$ - for $3-8 ; 100 \mu \mathrm{m}$ - for $9-16$.

Hypnum vaucheri Lesq., Mém. Soc. Sci. Nat. Neuchatel 3(3): 48. 1846.

Fig. 46

Plants small to medium-sized, in compact green, yellow-green or yellow-brown mats. Stem prostrate to erect-ascending (often branches are erect from prostrate stem); ca. 2 cm long; regularly branched, branches to $6 \mathrm{~mm}$ long. Pseudoparaphyllia semiorbicular to rounded-rectangular. Axillary hairs 3-celled, 40-60 $\mu \mathrm{m}$, apical cell 20-30 $\times 9-10 \mu \mathrm{m}$. Stem leaves falcate, $0.9-1.3 \times 0.4-0.6 \mathrm{~mm}$, ovate, concave; margins plane, involute in the middle, subentire. Branch leaves $0.9-1.0 \times 0.3-0.4 \mathrm{~mm}$. Laminal cells 30-35(-40) $\times 7-8$ (5-6/2). Alar cells subquadrate, forming an extensive indistinctly delimited group, 10-15 cells along the margin. Dioicous. Sporophyte not seen in Altai.

Hypnum vaucheri is similar to some forms of $H$. cupressiforme, especially its var. julaceum, and some authors even consider these speceis to be conspecific (cf. Crum \& Anderson, 1981). Sometimes the shape of paraphyllia (subfilamentose to lanceolate in $\mathrm{H}^{\mathrm{C}} \mathrm{Cu}$ - pressiforme/ broadly ovate in $H$. vaucheri) needs to be examined, though in most cases shorter laminal cells and numerous angular cells are enough to recognize this species.

Distribution: This species has a wide distribution throughout the Holarctic, obviously preferring more xeric regions within the Arctic, forest- and steppe zones. In Altai it grows at all elevations, on soil and rocks, sometimes in very dry steppes.

Specimens examined: Azhi Cape $440 \mathrm{~m}(21 / 34) ; B a-$ yas Lake $1850 \mathrm{~m}(0 / 614)$; Berekhtuyaryk $1600 \mathrm{~m}(0 /$ 612); Chainary Creek, upper course $1800 \mathrm{~m}$ (34/199); Chemal $400 \mathrm{~m}(29 / 39 ; 29 / 40)$; Chemal, $10 \mathrm{~km}$ upstream along Katun 450 m (34/145; 34/170); Derbogach 450 m (0/33); Gorno-Altaisk (SE edge) $600 \mathrm{~m}$ (23/16); Kairu Creek, 8 km upstream $1000 \mathrm{~m}(15 / 38)$; Kairu-Bazhi Peak $2050 \mathrm{~m}(13 / 171), 2100 \mathrm{~m}(13 / 81) ;$ Kobukhta $550 \mathrm{~m}(0 /$ 621), 600 m (0/226); Kokorya Creek 2400 m (32/51); Kukol 1800 m (0/613;0/624), 2000 m (0/620); Malyi Yaloman $900 \mathrm{~m}(25 / 154 ; 25 / 30), 1050 \mathrm{~m}(25 / 136 ; 25 /$ 82), 1200 m (25/131); Malyi Yaloman Creek, 2 km up- 

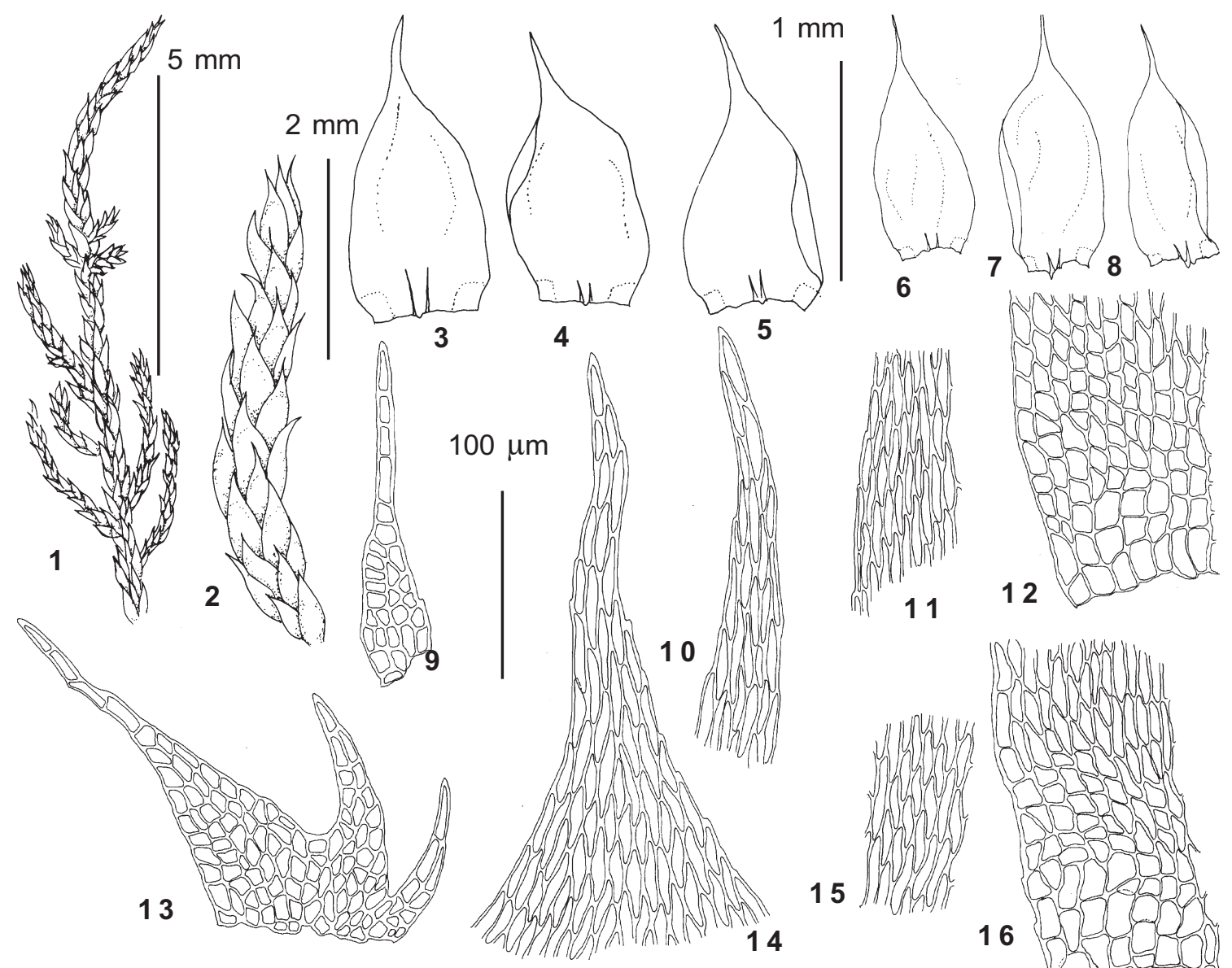

Fig. 49. Hypnum cupressiforme var. julaceum Brid. (from Kayakkatuyarykskij Creek $1930 \mathrm{~m}$ Ignatov 3/189): 1-2 habit; 3-5 - stem leaves; 6-8 - branch leaves; 9, 13 - pseudoparaphyllia; 10 - upper laminal cells of stem leaf; 11 middle laminal cells of stem leaf; 12 - alar cells of stem leaf; 14 - upper laminal cells of branch leaf; 15 - middle laminal cells of branch leaf; 16 - alar cells of branch leaf. Scale bars: $5 \mathrm{~mm}$ - for 1; $2 \mathrm{~mm}-$ for 2; $1 \mathrm{~mm}-$ for 3-8; $100 \mu \mathrm{m}$ - for $9-16$.

stream $850 \mathrm{~m}(25 / 168), 1100 \mathrm{~m}(25 / 169) ;$ Tabozhok Creek, 12 km upstream $2200 \mathrm{~m}(30 / 132 ; 30 / 134 ; 30 / 139 ; 30 /$ 141); Tabozhok Creek, 8 km upstream $2050 \mathrm{~m}(30 / 133$ $30 / 146 ; 30 / 147), 2250 \mathrm{~m}(30 / 136 ; 30 / 137), 2500 \mathrm{~m} \mathrm{(30/}$ 135; $30 / 144)$; Tabozhok Peak $2350 \mathrm{~m}(31 / 306$; $31 / 313$; $31 / 315 ; 31 / 321 ; 31 / 322), 2450 \mathrm{~m}$ (31/307); Tokpak Creek, upper course $2400 \mathrm{~m}(36 / 386)$; Ulagan $1220 \mathrm{~m}$ (36/236); Ust-Sema $350 \mathrm{~m}(24 / 77)$; Yailyu $450 \mathrm{~m} \mathrm{(0/}$ 622); Yakhansoru Lake $1870 \mathrm{~m}$ (Zolotukhin 28.VI.1990); Yazula $1600 \mathrm{~m}(0 / 618)$.

Hypnum cupressiforme Hedw., Sp. Musc. 291. 1801.

Figs. $47-51$

Plants medium-sized to rather robust, green, yellow to brownish. Stem prostrate to erect, complanate to subjulaceous, 3-4(8) cm long; epidermal cells not differentiated; regularly pinnate-branched to nearly unbranched; branches to 7(12) mm long. Pseudoparaphyllia subfilamentose to lanceolate, sometimes fused at base and bi- or trilobed. Axillary hairs 4-5celled, 100-150 $\mu \mathrm{m}$ long, apical cell ca. $50 \times 11 \mu \mathrm{m}$.
Leaves falcate to nearly straight (1.1-)1.4-1.8(-2.0) $\times(0.4-) .5-0.6(-0.7) \mathrm{mm}$, ovate-lanceolate; margins serrulate above, often recurved below. Laminal cells 40-75 × 5-7 (4-5/1.5-2) $\mu \mathrm{m}$. Alar subquadrate cells numerous, \pm distinctly delimited.

Dioicous. No sporophytes observed in Altai, or in other inland regions of Russia. The following description of sporophytes was made from European specimens. Perichaetial leaves erect, plane. Seta ca. 2 $\mathrm{cm}$. Capsule ca. $2 \mathrm{~mm}$ long. Operculum rostrate. Annulus of 2-3 row of cells, deciduous. Exostome teeth ca. $0.5 \mathrm{~mm}$ long, gradually tapered, nearly entire; perfectly striolate below; in the middle densely papillose on many plates; in the upper part with low medium papillae in longitudinal rows; dorsal trabeculae low-papillose, with non-incrassate margin; ventral surface and trabeculae smooth or with rare low papillae. Endostome as long as the teeth, basal membrane about $0.2 \mathrm{~mm}$ high; segments perforate; cilia nodose. Spores ca. $15 \mu \mathrm{m}$. 


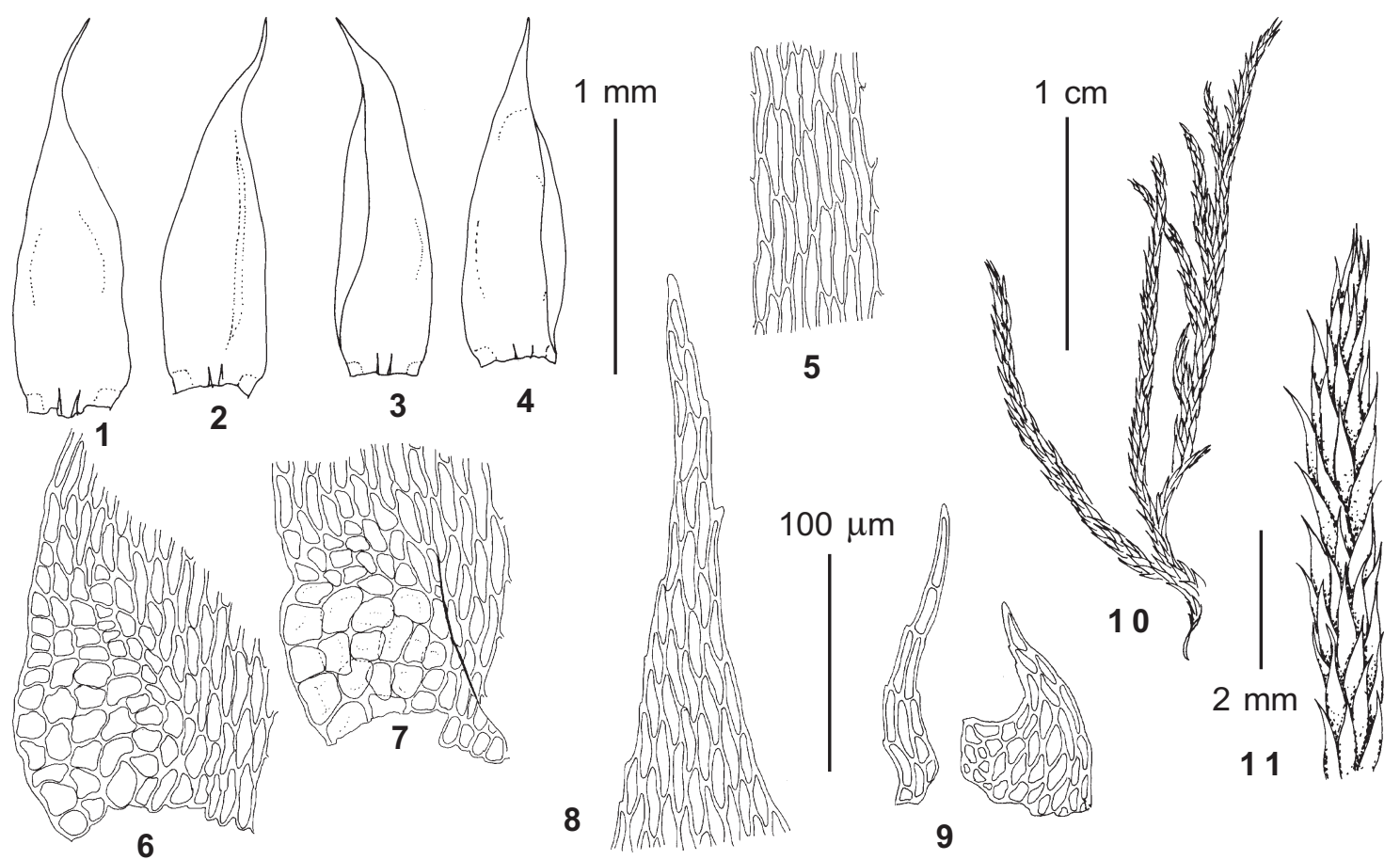

Fig. 50. Hypnum cupressiforme var. subjulaceum Mol. (from Bogoyash Creek, upper course $2550 \mathrm{~m}$ Ignatov 36/255): 1-4 - leaves; 5 - middle laminal cells; 6-7 - alar cells; 8 - upper laminal cells; 9 - pseudoparaphyllia; 10-11 - habit. Scale bars: $1 \mathrm{~cm}$ - for $10 ; 2 \mathrm{~mm}$ - for $11 ; 1 \mathrm{~mm}$ - for $1-4 ; 100 \mu \mathrm{m}$ - for $5-9$.

In Altai this species is enormously polymorphous, represented by var. cupressiforme (common in the forest, rarely in the subalpine zones, typically on trunks and in diffuse shade); var. filiforme (rather rare, nearly at the same elevations, but usually on deeply shaded rocks); var. julaceum (rare at about the tree-line), and var. subjulaceum (usually in the subalpine and alpine zones, but with a number of localities in the forest zone; usually on well exposed rocks). The latter variety is the most peculiar and some authors consider it as a separate species. Hypnum cupressiforme var. subjulaceum has a tendency to show complanate foliage (superficially resembling Callicladium). Alar cells are typically strongly colored, thick-walled, porose, and form a well-delimited concave group. However in many collections of var. subjulaceums some marginal or submarginal alar cells became larger, more transparent, with rather thin, non-porose walls. A key to the 9 varieties recognized within Hypnum cupressiforme was published by Ando (1993).

var. cupressiforme

Fig. 47

Plants \pm regularly and often densely pinnate- branched, usually green. Stem leaves falcate-secund, 1.2-2.0 $\times 0.4-0.6 \mathrm{~mm}$, subentire to slightly serrulate. Branch leaves 1.0-1.5 × 0.3-0.4 mm. Laminal cells $40-70 \times 6-7(4-5 / 2) \mu \mathrm{m}$, in the alar region subquadrate cells opaque, thick-walled, forming a distinctly delimited group.

Specimens examined: Akkurum, $3 \mathrm{~km}$ downstream by Chulyshman: $550 \mathrm{~m}$ (Zolotukhin 22.IX.1989); Ayukol: $1100 \mathrm{~m}(0 / 1694)$; Bayas Creek, at mouth: $500 \mathrm{~m}(0 /$ 1699); Chiri Creek, $0.5 \mathrm{~km}$ upstream: $450 \mathrm{~m} \mathrm{(17/104;}$ 17 71); Chulcha River, in middle course: $1000 \mathrm{~m}$ (9/ 156); $1100 \mathrm{~m}$ (9/52); Kairu Creek, 8 km upstream: 1000 m (15/69); Kairu-Bazhi Peak: 2100 m (13/43); Karagai: $440 \mathrm{~m}(0 / 271)$; Kayakkatuyarykskij Creek: $1930 \mathrm{~m}$ (3/ 223); $2100 \mathrm{~m}$ (7/121); Korbu: $440 \mathrm{~m}$ (0/1696); Kukol: $1750 \mathrm{~m}$ (0/1708); Kyga River, 2 km upstream: $600 \mathrm{~m}$ (0/1700); Srednij Shaltan Creek: $730 \mathrm{~m}(0 / 1697)$; Tura Creek, in middle course: $1300 \mathrm{~m}(28 / 10 ; 28 / 18)$; Yailyu: $440 \mathrm{~m}(0 / 1693 ; 0 / 1698) ; 450 \mathrm{~m}(0 / 632)$; Yakhansoru Lake: 1850 m (Zolotukhin 28.VI.1990).

var. filiforme Brid., Musc. Rec. 2(2): 138. 1801.

Fig. 48

Plants irregularly to regularly, but not densely pinnate-branched, usually green. Stem leaves nearly straight, $1.0-1.4 \times 0.3-0.4 \mathrm{~mm}$, less serrulate than type variety to nearly entire. Branch leaves 1.0-1.2 $\times 0.25$ $0.3 \mathrm{~mm}$. Laminal cells $40-75 \times 5(3 / 2) \mu \mathrm{m}$, in the alar region subquadrate cells opaque, thick-walled, forming a distinctly delimited group. 

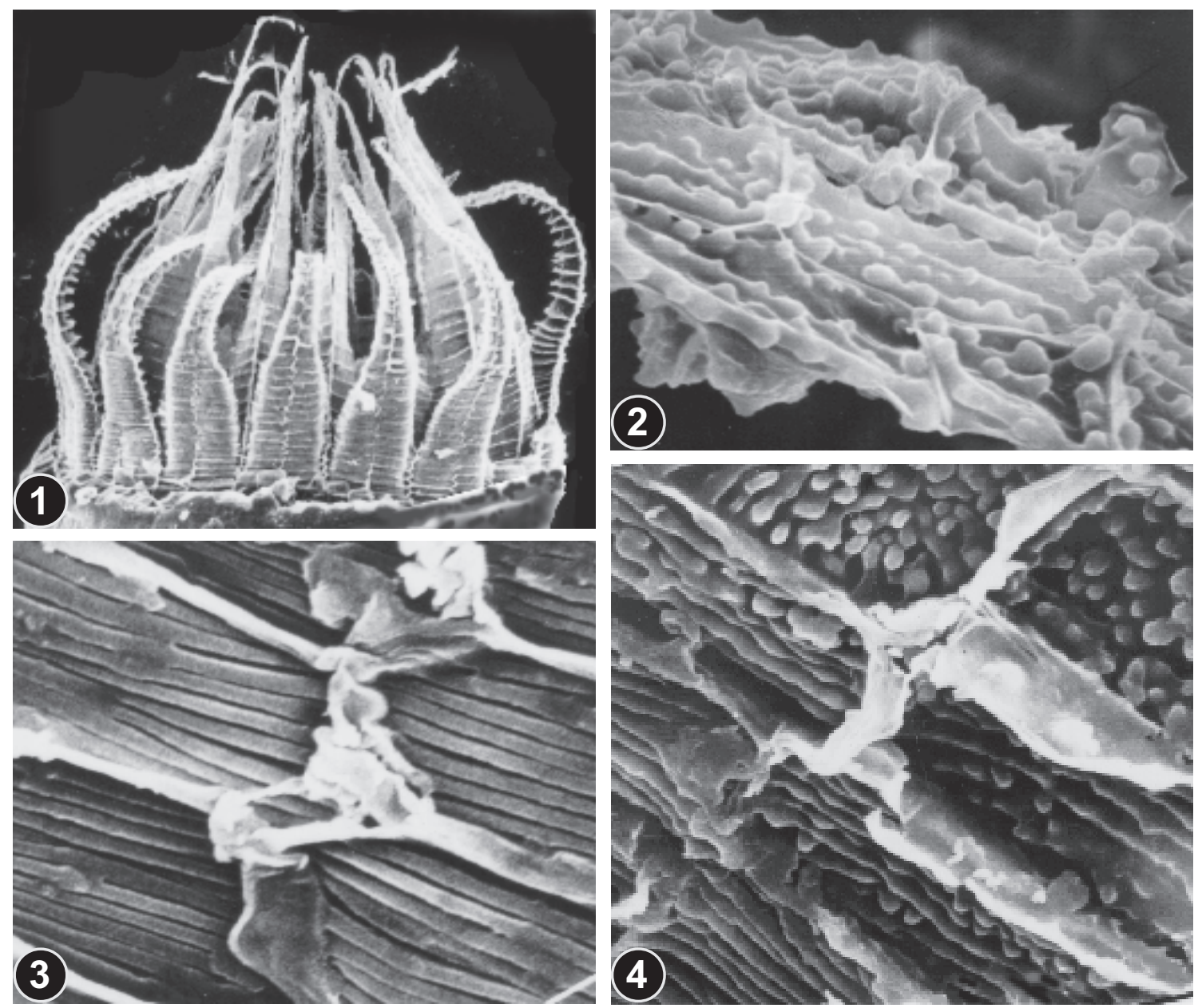

Fig. 51. Hypnum cupressiforme Hedw. var. cupressiforme (from Finland, Brotherus, 291C): 1 - peristome (210×); 2 - outer surface of exostome tooth in upper part (3500×); 3 - outer surface of exostome tooth in lower part (5000×); 4 - outer surface of exostome tooth in transition zone $(4000 \times)$.

Specimens examined: Chulcha River, in middle course $1200 \mathrm{~m}(9 / 24)$; Kamga Creek, 11 km upstream: $560 \mathrm{~m}$ (0/1524); Kayakkatuyarykskij Creek: $1850 \mathrm{~m}(8 / 156)$.

var. julaceum Brid., Spec. Musc. 2: 216. 1812.

Fig. 49

Plants irregularly pinnate-branched, green in young parts to yellow brown, julaceous. Stem leaves 1.1-1.2 $\times 0.4-0.5 \mathrm{~mm}$, from the ovate base abruptly and shortly erect-acuminate, subentire. Branch leaves somewhat larger, $1.3 \times 0.6-0.7 \mathrm{~mm}$. Laminal cells $40-$ $50(-60) \mu \mathrm{m}$.

Specimens examined: Kayakkatuyarykskij Creek: 1930 $\mathrm{m}(3 / 189)$

var. subjulaceum Mol., Ber. Naturh. Ver. Augsburg. 18: 183. 1865.

Fig. 50

Plants irregularly to regularly, but not densely pinnate-branched, usually yellow-brown (green in the uppermost portion). Stem leaves nearly straight,
$1.3-1.5(-2.0) \times 0.4-0.5(0.7) \mathrm{mm}$, serrulate to subentire. Branch leaves slightly differentiated. Laminal cells $45-75 \times 6(4 / 2) \mu \mathrm{m}$, thick-walled and at places distinctly porose; in the alar region sunquadrate cells opaque, thick-walled and dark brown, forming a distinctly delimited excavate group; sometimes alar cells partly inflated.

Specimens examined: Ayulyuyuzyuk Creek $2050 \mathrm{~m}$ (0) 165), 2150 m (0/128; 0/377); Bogoyash Creek, upper course $2550 \mathrm{~m}(36 / 255)$; Chulcha River, in middle course $850 \mathrm{~m}$ (Zolotukhin 18.IX.1989), $960 \mathrm{~m}$ (9/92); KairuBazhi Peak 2300 m (13/130); Kayakkatuyarykskij Creek $1760 \mathrm{~m}$ (8/43), $1850 \mathrm{~m}$ (8/288), $1970 \mathrm{~m}$ (7/125), $2000 \mathrm{~m}$ (3/272); Kobiguayuk Creek $2300 \mathrm{~m}$ (0/203); Kukol 1800 m (0/1524; 0/1731), 1900 m (0/1523); Ok-Porok Creek, at mouth $440 \mathrm{~m}(0 / 634 \mathrm{a})$; Srednij Shaltan Creek $740 \mathrm{~m}$ (0/1520); Tabozhok Peak $2300 \mathrm{~m}(31 / 316), 2700 \mathrm{~m}$ (30/ 142); Yailyu $450 \mathrm{~m}(0 / 1523)$; Yakhansoru Lake $1870 \mathrm{~m}$ (Zolotukhin 28.VI.1990). 

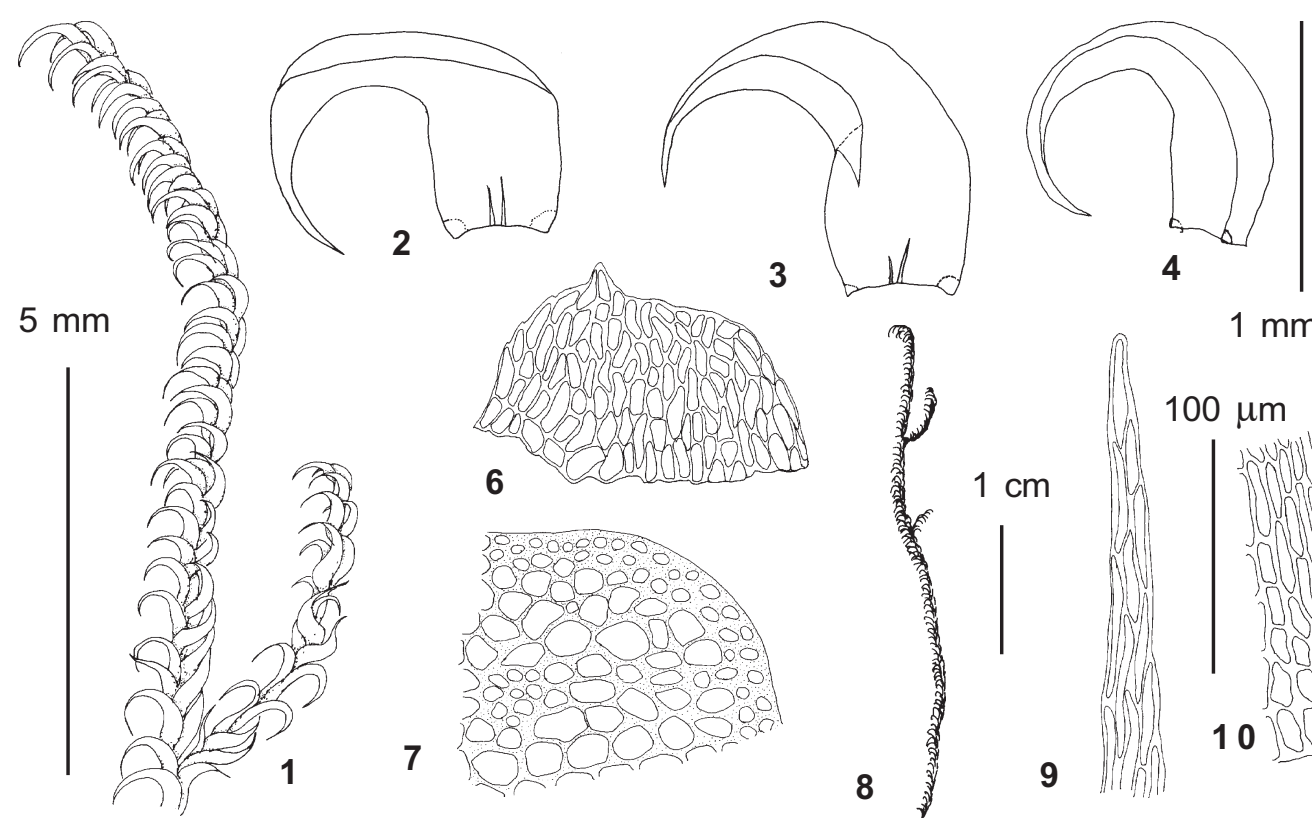
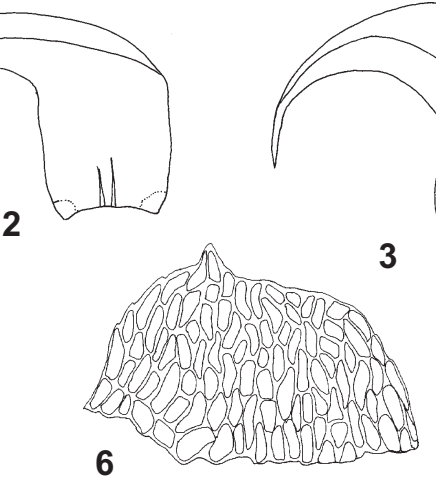

7

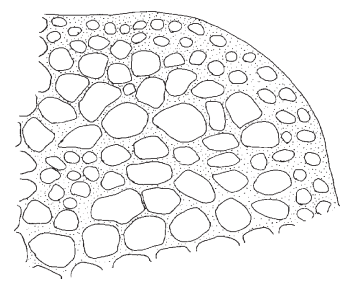

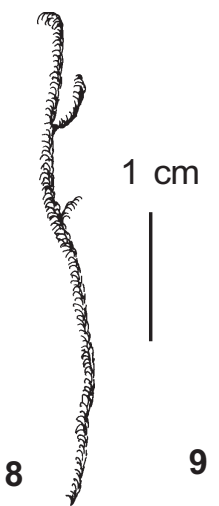

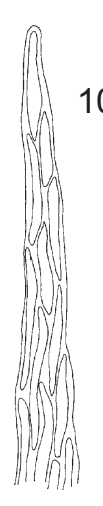

$1 \mathrm{~mm}$

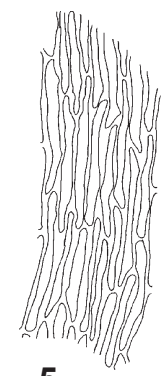

$100 \mu \mathrm{m}$

5

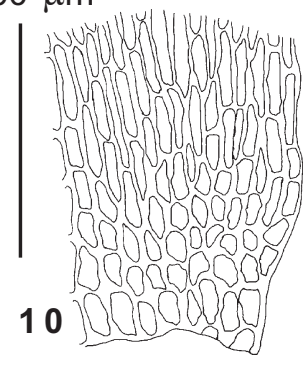

Fig. 52. Hypnum bambergeri Schimp. (from Tabozhok Peak $2800 \mathrm{~m}$ Ignatov 0/2030): 1,8 - habit; 2-4 - leaves; 5 - middle laminal cells; 6 - pseudoparaphyllium; 7 - stem cross-section; 9 - upper laminal cells; 10 - alar cells. Scale bars: $1 \mathrm{~cm}-$ for $8 ; 5 \mathrm{~mm}$ - for $1 ; 1 \mathrm{~mm}$ - for $2-4 ; 100 \mu \mathrm{m}$ - for $5-7,9-10$.

Transitions between var. cupressiforme and var. subjulaceum are found in specimens:

Bogoyash Creek, upper course $2400 \mathrm{~m}$ (36/245); Chainary Creek, upper course: $1800 \mathrm{~m}(34 / 200)$; Chiri Creek, $0.5 \mathrm{~km}$ upstream: $450 \mathrm{~m}(17 / 74) ;$ Tabozhok Peak 2700 $\mathrm{m}(31 / 312)$.

Transitions between var. subjulaceum and var. filiforme in specimen:

Chemal Creek, $3 \mathrm{~km}$ upstream $450 \mathrm{~m}$ (34/32).

Hypnum bambergeri Schimp., Syn. Musc. Eur., ed. 2, 2: 698. 1860.

Fig. 52

Plants medium-sized to large, yellow-green in young parts, soon becoming brown. Stem prostrate to ascending, $4 \mathrm{~cm}$ long; without hyalodermis and with weak central strand; branches few, to $8 \mathrm{~mm}$ long. Pseudoparaphyllia broadly-ovate to broadly triangular. Axillary hairs 3-4-celled, 120-140 $\mu \mathrm{m}$ long, apical cell 40-65 $\times 10 \mu \mathrm{m}$. Stem leaves crowded, falcate to circinate-secund, 1.5-1.8 $\times 0.5-0.6 \mathrm{~mm}$; margins plane, entire. Branch leaves 1.3$1.4 \times 0.3-0.4 \mathrm{~mm}$. Laminal cells 40-65×6-7 (3.5-5/2.02.5) $\mu \mathrm{m}$, thick-walled, porose. Alar cells subquadrate to rectangular, thick-walled, forming a distinct brown excavate group. Dioicous. Sporophytes not seen in Altai.

Distribution: Hypnum bambergeri occurs in the Arctic and in high mountains of Europe, Azores, South Siberia, in North America to British Columbia in the west, and to Newfoundland and Quebec in the east. In Altai it was found in few places at or above the tree-line, on rocks or in wet tundras.

Specimens examined: Tabozhok Peak 2550 m (0/2063), $2800 \mathrm{~m}(0 / 2030 ; 0 / 2036)$.
Hypnum procerrimum Mol., Flora 49: 458. 1866. - Pseudostereodon procerrimum (Mol.) Fleisch. in Broth., Nat. Pfl. (ed. 2) 11: 455. 1925. - Ctenidium procerrimum (Mol.) Lindb., Bot. Not. 1882: 26. 1882.

Fig. 53

Plants medium-sized, in dense golden-brownish tufts. Stem prostrate, 2-3 cm long; without hyalodermis, with weak central strand; \pm regularly but rarely branched, branches $4 \mathrm{~mm}$ long. Pseudoparaphyllia broadly-triangular to transversely ovate. Axillary hairs 4-9-celled, all colored, 140-200 $\mu \mathrm{m}$ long, apical cell 50-60 × 10-12 $\mu \mathrm{m}$. Stem leaves strongly falcate, 2.5-2.8 $\times 0.6-0.7 \mathrm{~mm}$, cordate-auriculate at base, plicate, margin plane. Branch leaves 1.4-1.5 × 0.3-0.4 $\mathrm{mm}$. Laminal cells $40-60 \times 6(3.5 / 2.5) \mu \mathrm{m}$, thickwalled, porose. Alar cells isodiametric, thick-walled, in a large indistinctly delimited group, lowermost cells sometimes inflated. Dioicous. Sporophytes unknown in this species.

This species has leaves with a peculiar cordate-auriculate base and weakly differentiated alar cells and for these reasons is placed sometimes in Ctenidium (cf. Corley \& al., 1981; Nyholm, 1965). However other characters, such as entire strongly falcate leaves with smooth (or nearly so) laminal cells, suggest its more close relation to Hypnum, rather than to Ctenidium. The segregation of this species in the monotypic genus Pseudostereodon is possible in case of further splitting of Hypnum. 


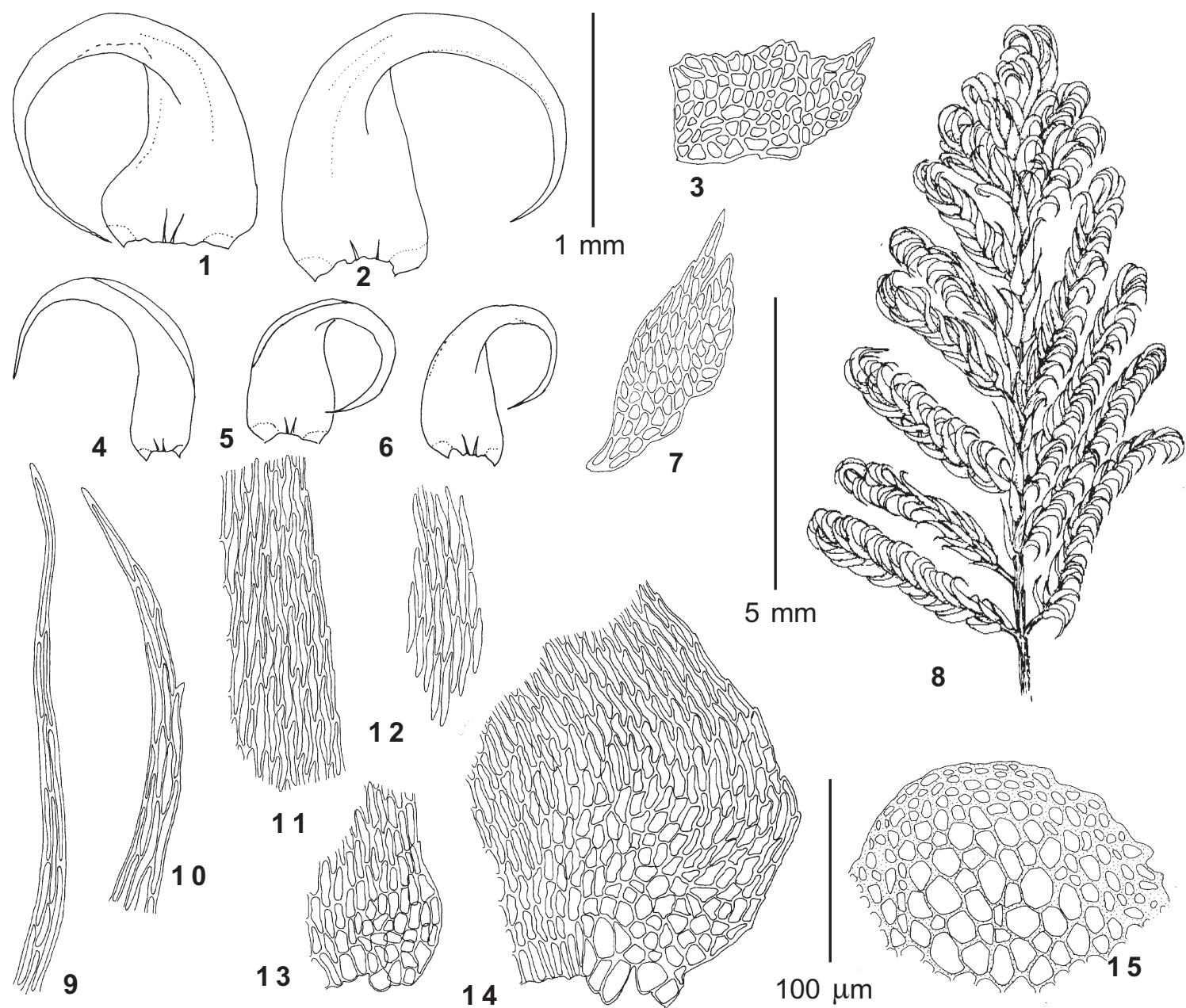

Fig. 53. Hypnum procerrimum Mol. (from Bogoyash Creek, upper course $2400 \mathrm{~m}$ Ignatov 36/66): 1-2 - stem leaves; 3, 7 - pseudoparaphyllia; 4-6 - branch leaves; 8 - habit; 9 - upper laminal cells of stem leaf; 10 - upper laminal cells of branch leaf; 11 - middle laminal cells of stem leaf; 12 - middle laminal cells of branch leaf; 13 - alar cells of branch leaf; 14 - alar cells of stem leaf; 15 - stem cross-section. Scale bars: $5 \mathrm{~mm}$ - for 8 ; $1 \mathrm{~mm}-$ for $1-2$, 4-6; 100 $\mu \mathrm{m}-$ for $3,7,9-15$.

Distribution: Hypnum procerrimum is more or less widely distributed in the Arctic and in high mountains of Central and South Europe, Caucasus, Siberia, Middle Asia, Mongolia, China (southward to Yunnan), and British Columbia and Alberta in North America. In Altai this species occurs in xeric tundras of South-East Altai, on rocks or soil.

Specimens examined: Ak-Turu Creek, upper course 2600 m (Bardunov 18.VII.1966 IRK!); Bogoyash Creek, upper course $2400 \mathrm{~m}(36 / 66), 2450 \mathrm{~m}(36 / 252)$; Kokorya Creek 2400 m (32/50); Tabozhok Peak 2350 m (31/314), 2400 m (31/331); Tutuoyuk Creek, upper course 2500 m (Zolotukhin \& al. 15.VII.1990).

Hypnum fauriei Card., Beih. Bot. Centralbl. 17: 41. 26. 1904.

Figs. $54 \& 55$

Plants medium-sized, in soft green to yellowishgreen tufts. Stem prostrate or ascending when grow- ing in dense tufts, to $5 \mathrm{~cm}$ long; regularly densely branching, with branches ca. $7 \mathrm{~mm}$ long. Epidermal cells indistinct to enlarged at places. Pseudoparaphyllia lanceolate-subulate, sometimes fused at base. Axillary hairs 3-celled, 70-120 $\mu \mathrm{m}$ long, apical cell $40-75 \times 8 \mu \mathrm{m}$. Stem leaves strongly falcate, 1.7-2.1 $\times$ $0.5-0.7 \mathrm{~mm}$, gradually tapered in long narrow acumen; margins serrulate above. Branch leaves 1.1-1.4 $\times 0.4 \mathrm{~mm}$. Laminal cells $50-80 \times 4(3 / 1) \mu \mathrm{m}$. In alar regions cells subquadrate to rectangular, some lowermost - enlarged and thin-walled, forming a rather distinctly (in stem leaves) or indistinctly (in branch leaves) delimited group.

Autoicous. Sporophytes frequent. Perichaetial leaves 1.8-2.5 $\times 0.6 \mathrm{~mm}$, entire to serrulate, plicate, with indistinct double costa. Seta 2-3 cm. Capsule 15-20(25) $\mathrm{mm}$ long, arcuate, slightly furrowed when dry. Oper- 


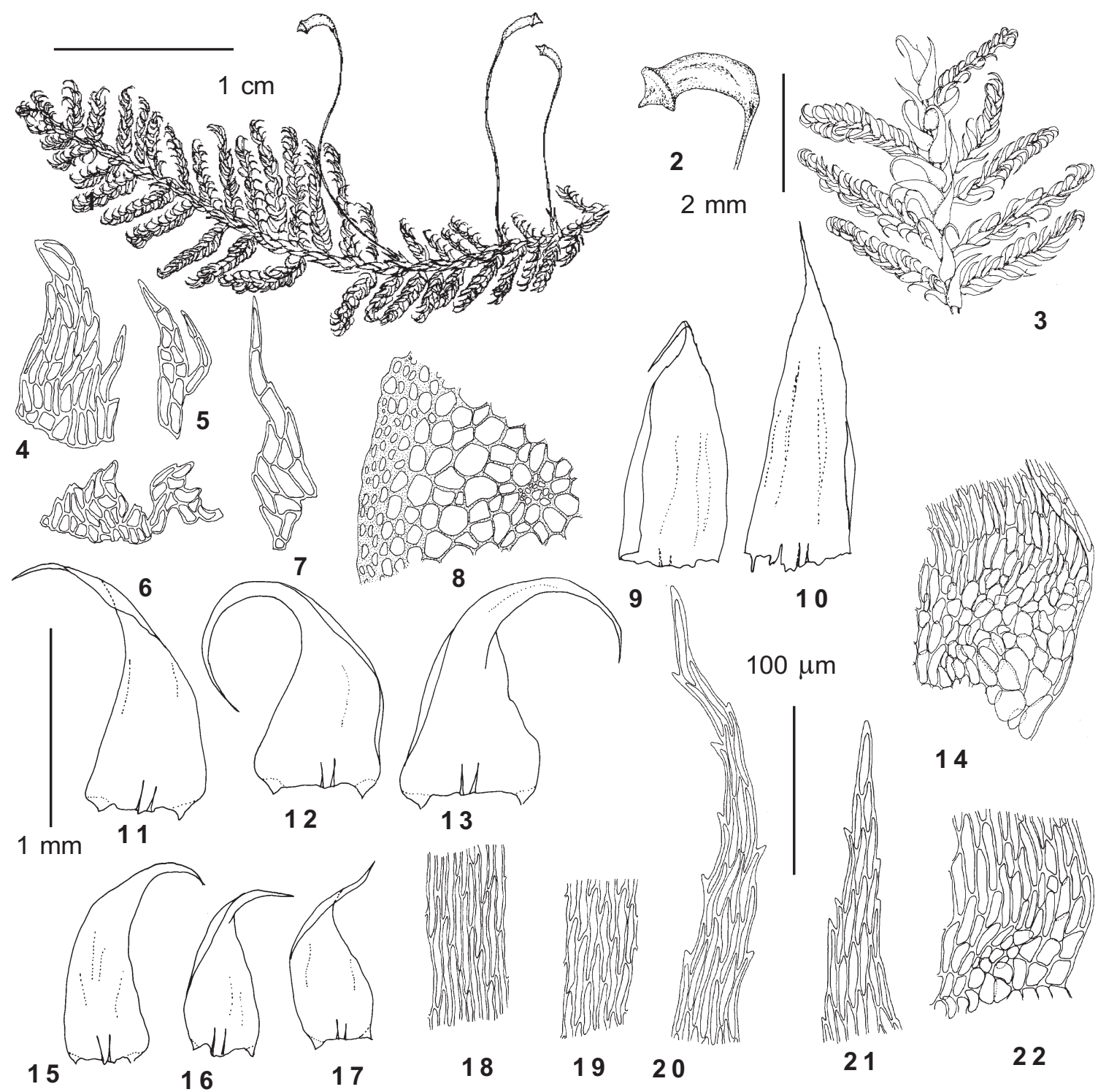

Fig. 54. Hypnum fauriei Card. (from Yurga 450 m Ignatov 0/1713): 1,3 - habit; 2 - capsule; 4-7 - pseudoparaphyllia; 8 - stem cross-section; 9-10 - perichaetial leaves; 11-13 - stem leaves; 14 - alar cells of stem leaf; 15-17 branch leaves; 18 - middle laminal cells of stem leaf; 19 - middle laminal cells of branch leaf; 20 - upper laminal cells of stem leaf; 21 - upper laminal cells of branch leaf; 22 - alar cells of branch leaf. Scale bars: $1 \mathrm{~cm}-$ for $1 ; 2$ $\mathrm{mm}$ - for $2-3 ; 1 \mathrm{~mm}$ - for $9-13,15-17 ; 100 \mu \mathrm{m}$ - for $4-8,14,18-22$.

culum conic, shortly acuminate. Exostome teeth 0.55 $\mathrm{mm}$ long, gradually tapered, distinctly serrate in the upper third; imperfectly striolate below; in the middle densely papillose on many plates; in the upper part with rare minute papillae arranged in indistinct rows, and high-conic papillae along relatively low dorsal trabeculae and non-incrassate margin; ventral surface and trabeculae with dense conic-spinulose papillae. Endostome $0.65 \mathrm{~mm}$ long, basal membrane $0.24 \mathrm{~mm}$ high; cilia nodose. Spores $16-20 \mu \mathrm{m}$.

Hypnum fauriei in Altai is distinct due to the medium size of plants with dense regularly pinnate branching. This species is close to $H$. fertile Sendtn., but differs from it in: (1) stem leaves wider lanceolate, 1,4-2.2 × 0.45-0.75 mm vs. $1.3-2.2 \times 0.4-0.5 \mathrm{~mm}$; (2) median laminal cells shorter, (40-)50-70(-80) $\mu \mathrm{m}$ long vs. (50)60-80(-90) $\mu \mathrm{m}$; (3) capsule longer, 2-3 mm long (urn) vs. 1.5-2.5 mm; (4) spores larger, 15-22(24) $\mu \mathrm{m}$ in diameter vs. (10-)13-16 (-20) $\mu \mathrm{m}$. Previous records of $H$. fertile from 

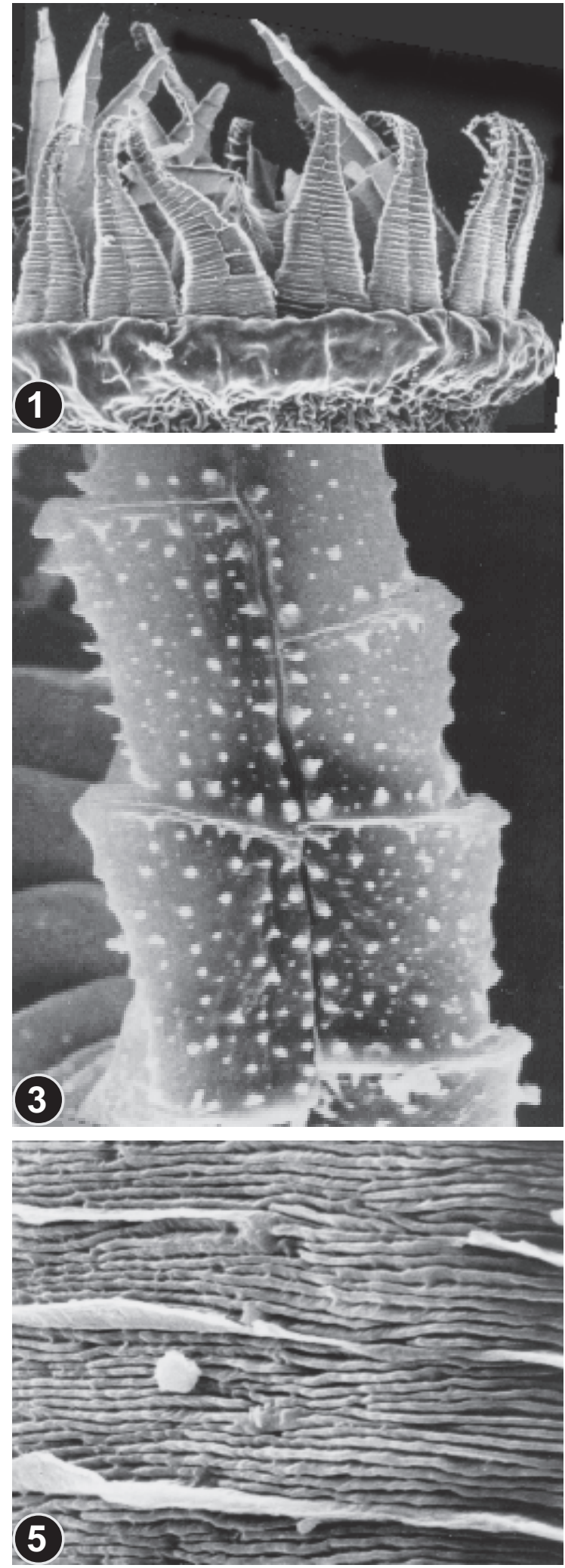
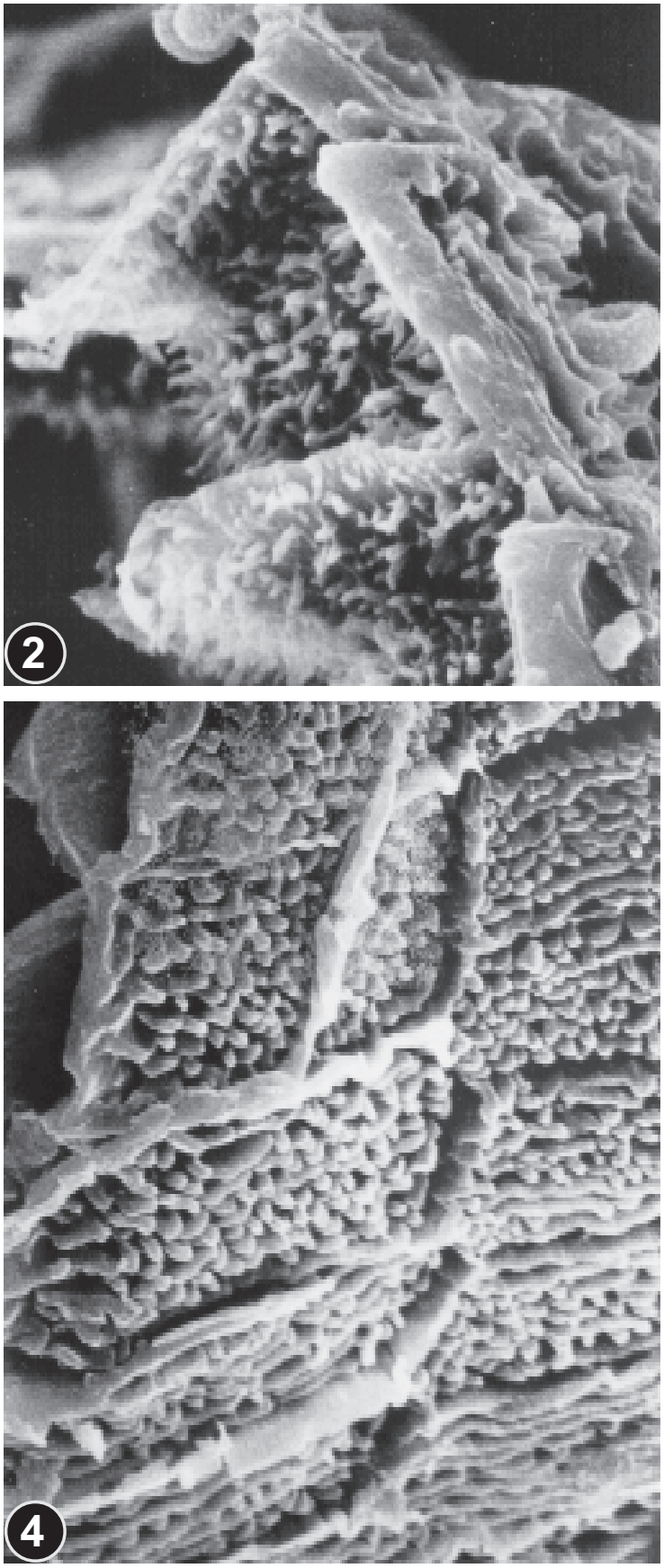

Fig. 55. Hypnum fauriei Card. (from Karagai $440 \mathrm{~m}$ Ignatov 0/1710): 1 - peristome (190×); 2 - side view of exostome tooth in upper part, showing echinate-papillose inner trabeculae $(5000 \times) ; 3-$ front view of exostome tooth in upper part $(4000 \times) ; 4-$ outer surface of exostome tooth in transition zone and below (4400×); 5 - outer surface of exostome tooth in lower part $(4400 \times)$. 


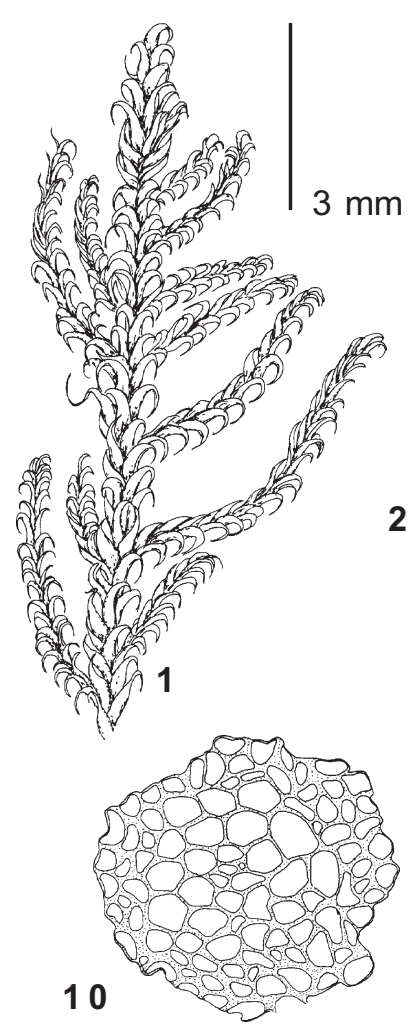

11
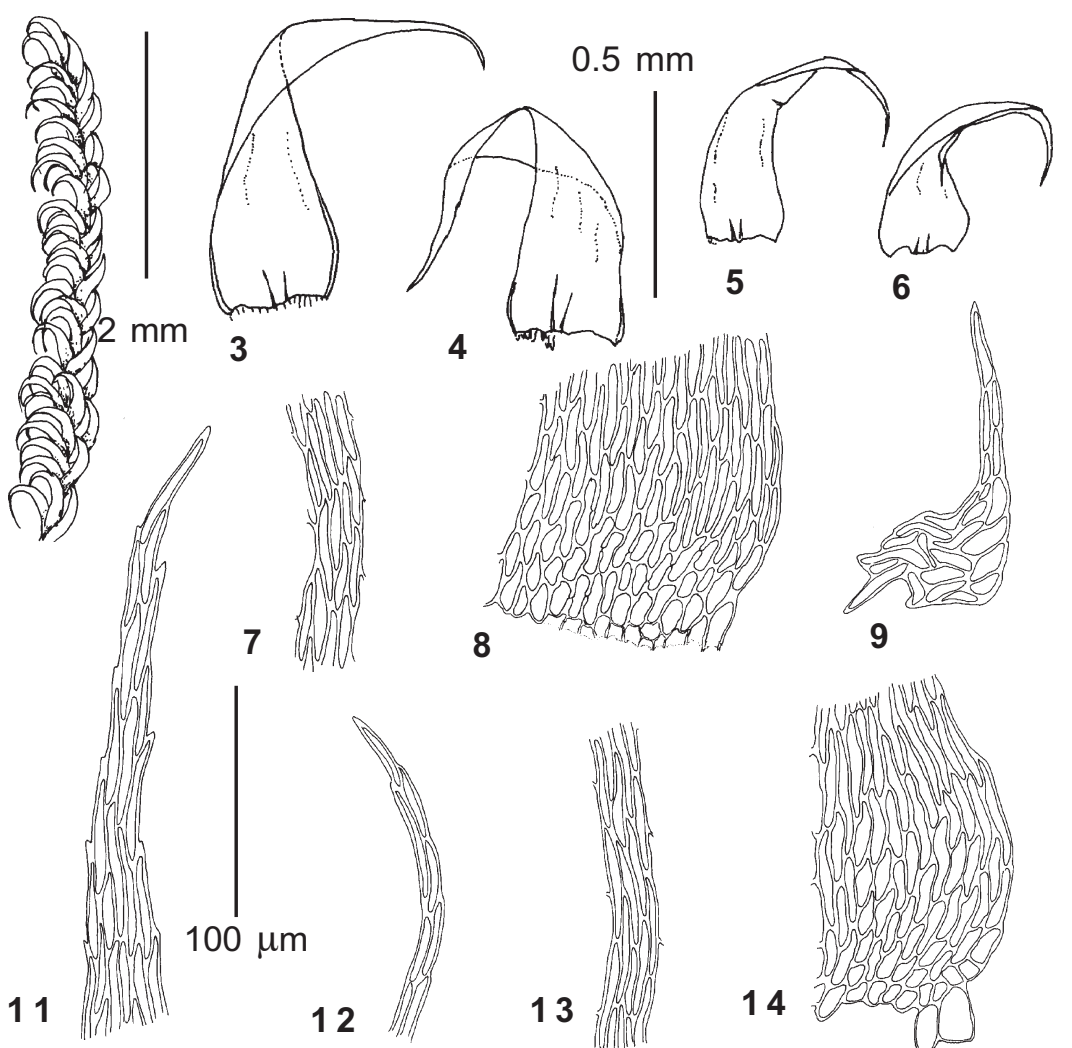

3

4
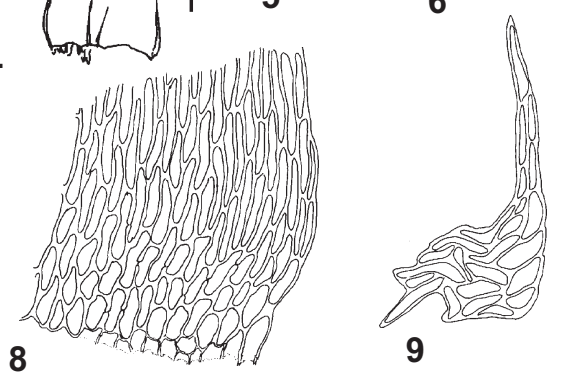

7

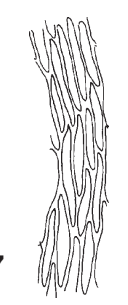

8

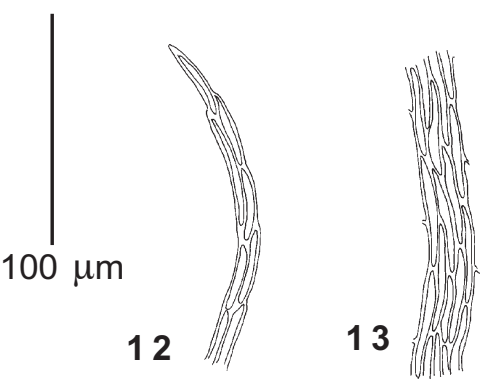

14

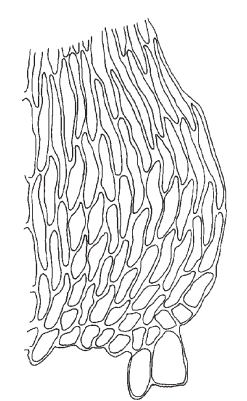

Fig. 56. Hypnum hamulosum B.S.G. (from Kobiguayuk Creek $2850 \mathrm{~m}$ Ignatov 0/223): 1-2 - habit; 3-4 - stem leaves; 5-6 - branch leaves; 7 - middle laminal cells of stem leaf; 8 - alar cells of stem leaf; 9 - pseudoparaphyllium; 10 - stem cross-section; 11 - upper laminal cells of stem leaf; 12 - upper laminal cells of branch leaf; 13 - middle laminal cells of branch leaf; 14 - alar cells of branch leaf. Scale bars: $3 \mathrm{~mm}-$ for $1 ; 2 \mathrm{~mm}-$ for $2 ; 0.5 \mathrm{~mm}-$ for $3-$ $6 ; 100 \mu \mathrm{m}-$ for $7-14$.

Altai (Ignatov, 1990) and other parts of Siberia (Brotherus, 1925) are based on misidentifications of $H$. fauriei.

Distribution: Hypnum fauriei occurs in Japan, Korea, China, Russian Far East and South Siberia, westward to Altai. In Altai it grows at lower elevations in the areas with especially mild climate (around Teletzkoye Lake and Katun River valley near Chemal). All collections were made from relatively dry rotten logs in partial shade.

Specimens examined: Chemal Creek, $3 \mathrm{~km}$ upstream 450 m (34/231); Chichelgan Range 800 m (0/1725); Kairu Creek, 8 km upstream 1000 m (15/116; 15/144); Karagai 440 m (0/1710); Kobukhta 450 m (0/1712); Yailyu $480 \mathrm{~m}(0 / 631)$; Yurga $450 \mathrm{~m}(0 / 1713)$.

Hypnum hamulosum B.S.G., Bryol. Eur. 6: 96. pl. 590. 1854 .

Fig. 56

Plants small for the genus, in soft green to yellowish-brown dense tufts. Stem prostrate to ascending, to $2 \mathrm{~cm}$ long; with enlarged epidermal cells; irregularly to \pm regularly branching, with branches ca. $4 \mathrm{~mm}$ long. Pseudoparaphyllia lanceolate to sub- ulate. Axillary hairs 3-celled, 60-70 $\mu \mathrm{m}$ long, apical cell $35-40 \times 8 \mu \mathrm{m}$. Stem leaves strongly falcate, 1.0$1.2 \times 0.3-0.4 \mathrm{~mm}, \pm$ plicate; margins recurved below, serrulate above. Branch leaves 0.7-0.9 $\times 0.2-0.3 \mathrm{~mm}$. Laminal cells $40-50 \times 4-5(3-4 / 1) \mu \mathrm{m}$. In alar regions few cells subquadrate, forming an indistinct group, sometimes 1-2 corner cells enlarged.

Dioicous. Sporophytes were observed in Altai in only one collection (deep wet canyon in mild climate). Perichaetial leaves $2.0 \times 0.4 \mathrm{~mm}$, plicate, coarsely serrate above, serrulate below. Seta $1.5 \mathrm{~cm}$. Capsule $2 \mathrm{~mm}$ long. Exostome teeth $0.35 \mathrm{~mm}$ long, gradually tapered, serrate; striolate below; in the middle densely papillose on many plates; in the upper part moderately papillose with low irregularly arranged papillae, with low dorsal trabeculae and non-incrassate margin; ventral surface and trabeculae smooth. Endostome normal for the genus, cilia nodose or somewhat appendiculate. Spores 11-14 $\mu \mathrm{m}$.

Hypnum hamulosum is easy to know by small plants with leaves strongly falcate, widely spreading from the stem or branches imme- 


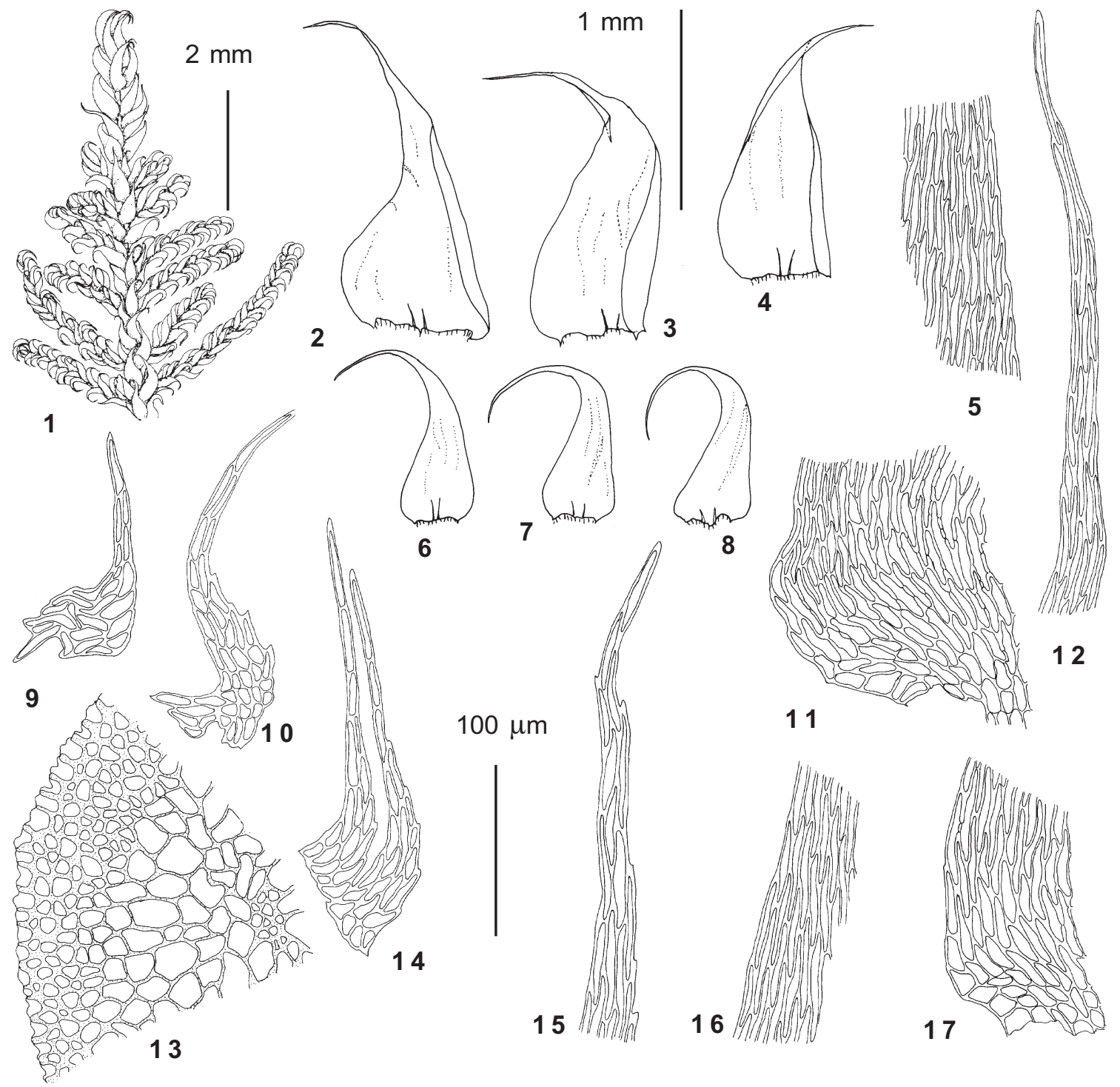

Fig. 57. Hypnum plicatulum (Lindb.) Jaeg. (from Kayakkatuyarykskij Creek $2100 \mathrm{~m}$ Ignatov 7 /120): 1 - habit; 24 - stem leaves; 5 - middle laminal cells of stem leaf; 6-8 - branch leaves; 9-10, 14 - pseudoparaphyllia; 11 - alar cells of stem leaf; 12 - upper laminal cells of stem leaf; 13 - stem cross-section; 15 - upper laminal cells of branch leaf; 16 - middle laminal cells of branch leaf; 17 - alar cells of branch leaf. Scale bars: $2 \mathrm{~mm}-$ for $1 ; 1 \mathrm{~mm}-$ for 2 $4,6-8 ; 100 \mu \mathrm{m}-$ for $5,9-17$.

diately from the insertion (while in other small Hypnum species occurring in Altai the leaf base is \pm appressed to the stem). A key for the species of the section Hamulosa has been published by Ando (1994).

Distribution: This species has a scattered distribution in the Holarctic, mostly in northern and mountain areas. It is rather common in Siberian mountains. In Altai it grows usually on wet and partially shaded rock outcrops (especially close to waterfalls), in all the altitudinal zones.
Specimens examined: Bolshoye Istyube Creek $470 \mathrm{~m}$ (Zolotukhin 5.VI.1986; 0/629; 18/127; 18/14); Chichelgan Cape 440 m (Zolotukhina 12.VII.1988); Chiri Creek, $0.5 \mathrm{~km}$ upstream $450 \mathrm{~m}(17 / 10)$; Kairu Creek, $16 \mathrm{~km} \mathrm{up-}$ stream $1400 \mathrm{~m}(14 / 18)$; Kairu Creek, 8 km upstream 1000 m (15/141); Kairu-Bazhi Peak 1700 m (13/92); Kamga Creek, 10 km upstream $500 \mathrm{~m}$ (0/104), $560 \mathrm{~m}$ (0/1704), $580 \mathrm{~m}(0 / 1721)$; Kamga Creek, $14 \mathrm{~km}$ upstream $660 \mathrm{~m}$ (0/1719); Karakol Lakes 1950 m (28/53); Kayakkatuyarykskij Creek 2050 m (3/59; 5/4); Kobiguayuk Creek $2850 \mathrm{~m}$ (0/223); Korbu 440 m (Zolotukhin 20.X.1988); Ok-Porok Creek, 1.5 km upstream $470 \mathrm{~m}(2 / 27)$; Srednij Shaltan Creek $670 \mathrm{~m}(0 / 1702)$; Yailyu $450 \mathrm{~m}$ (0/1703). 

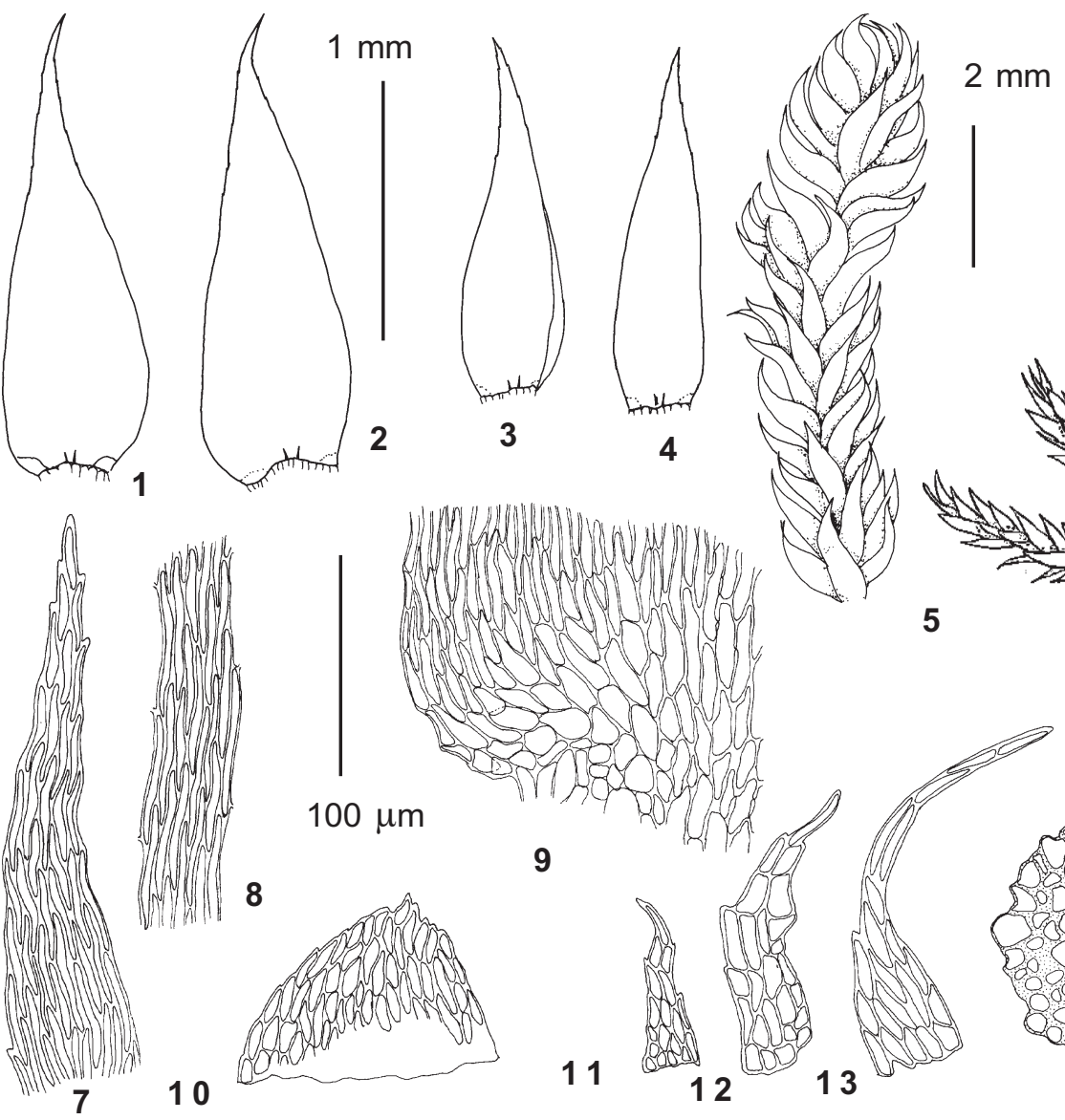

Fig. 58. Hypnum pratense J. Koch ex Spruce (from Gorno-Altaisk 400 m Ignatov 35/49): 1-2 - stem leaves; 3-4branch leaves; 5 - upper stem; 6 - habit; 7 - upper lamina cells of stem leaf; 8 - middle lamina cells of stem leaf; 9 - alar cells of branch leaf. 10 - proximal branch leaf; 11-13 - pseudoparaphyllia; 14 - stem cross-section. Scale bars: $5 \mathrm{~mm}$ - for $6 ; 2 \mathrm{~mm}$ - for $5 ; 1 \mathrm{~mm}-$ for $1-4 ; 100 \mu \mathrm{m}-$ for $-7-14$.

Hypnum plicatulum (Lindb.) Jaeg., Ber. St. Gall. Naturw. Ges. 1877-78: 316. 1880. - Stereodon plicatulus Lindb., Acta Soc. Sci. Fenn. 10: 251. 1872.

Fig. 57

Plants rather small, in yellow-green tufts. Stem prostrate, to $1.5 \mathrm{~cm}$ long; epidermal cells differentiated, but at places indistinctly so; regularly pinnatebranched (young branches elongate evenly, so shoot ends have usually characteristically triangular outline), branches to $4 \mathrm{~mm}$. Pseudoparaphyllia lanceolate to subulate. Axillary hairs 3-celled, $90 \mu \mathrm{m}$ long, apical cell ca. $60 \times 10 \mu \mathrm{m}$. Stem leaves falcate 1.0-1.5 $\times$ $0.5-0.8 \mathrm{~mm}$, triangular-lanceolate, rounded to cordate base, acuminate; margins subentire, plane. Branch leaves 0.9-1.5 × 0.4-0.5 mm. Laminal cells 55-70 $\times 4$ $(3 / 1) \mu \mathrm{m}$, in alar regions cells subquadrate, thinwalled, forming a small indistinct group. Dioicous. Sporophytes not seen in Altai.

Distribution: Hypnum plicatulum occurs mostly in Asia: Ural Mts. (from the Arctic to southern Urals), most of the Asian Arctic territories, moun- tains of South Siberia, Russian Far East, Mongolia, Korea and Japan. Outside Asia it is known from the Arctic in European Russia, North America and Greenland. In Altai this species grows in moist rocks (similar to $H$. hamulosum), in all the altitudinal zones (except the upper alpine), obviously preferring the subalpine belt. Schofield (1992) mapped the distribution of this species in North America.

Specimens examined: Ayukol $1000 \mathrm{~m}(0 / 630)$; Bayas Lake 1750 m (0/1720; 0/610); Karakol Lakes 1900 m (28/157; 28/54); Kayakkatuyarykskij Creek 1950 m (3/ 53), $2100 \mathrm{~m}(7 / 120)$; Kishte $440 \mathrm{~m}$ (Zolotukhin 11.VII.1988); Kobiguayuk Creek $2150 \mathrm{~m}$ (0/318); Uzunkel Lake $2050 \mathrm{~m}$ (Zolotukhin 23.VI.1990).

Hypnum pratense J. Koch ex Spruce, London J. Bot. 4:177. 1845. - Breidleria pratensis (J. Koch ex Spruce) Loeske, Stud. Morph. Syst. Laubm. 172. 1910.

Figs. 58 \& 59

Plants medium-sized to robust, in soft glossy light yellow-green tufts. Stem prostrate to ascending, densely complanate, to $4 \mathrm{~cm}$ long; with hyalodermis and 

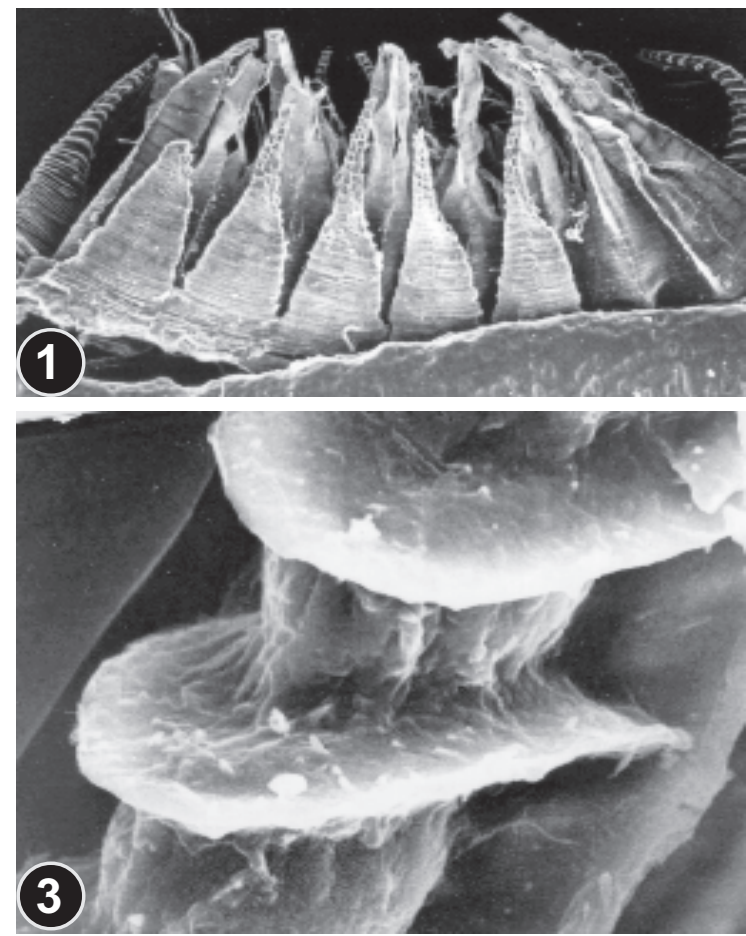

central strand; irregularly-branched. Pseudoparaphyllia broadly to narrowly lanceolate. Axillary hairs 45-celled, 80-120 $\mu \mathrm{m}$ long, apical cell 50-60 $\times 8 \mu \mathrm{m}$. Stem leaves straight or weakly falcate, 1.8-2.3 $\times 0.7$ $0.9 \mathrm{~mm}$, ovate-lanceolate, gradually acuminate, serrulate above. Branch leaves 1.3-1.4 $\times 0.4-0.5 \mathrm{~mm}$. Laminal cells $60-85 \times 4-5(3-4 / 1) \mu \mathrm{m}$, at base porose, in alar regions subquadrate, thin-walled, forming a indistinctly delimited group.

Dioicous. Sporophyte not found in Altai, and very rare else where in the range. The following description of one specimen from Central Russia may be useful. Perichaetial leaves plicate. Seta ca. $3 \mathrm{~cm}$, Capsule $3 \mathrm{~mm}$ long. Exostome teeth ca. $0.4 \mathrm{~mm}$ long, abruptly tapered, serrulate in the distal third; striolate below; in the middle densely papillose; in the upper part with rare, irregularly arranged papillae; dorsal trabeculae and incrassate margins prominent, nearly smooth; ventral trabeculae smooth. Endostome cilia nodose.

The genus Breidleria is segregated sometimes from Hypnum for the species having large plants and large epidermal cells. Several species were placed in this genus (see the review by Hedenäs, 1992), but most manuals recognize it for two widespread species Hypnum (Breidleria) pratense and Hypnum (Breidleria) lindbergii. Hedenäs (1992) found the latter species to be more close to Calliergonella cuspidata, and transferred $H$. lindbergii to Calliergonella. Our observations on exostome ornamentation increase the number of differences

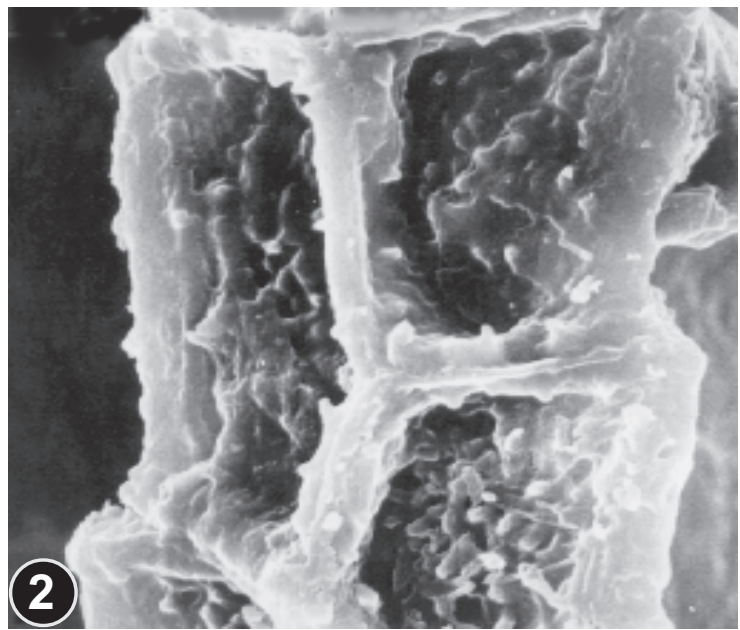

Fig. 59. Hypnum pratense J. Koch ex Spruce (from Central Russia, Yaroslavl Province, Zickendrath, 31.V.1891, ex MW): 1 - peristome (110×); 2 - outer surface of exostome tooth in upper part $(4400 \times)$; $3-$ inner surface of exostome tooth in upper part $(3600 \times)$.

between Hypnum pratense and Calliergonella lindbergii. However Calliergonella cuspidata and $C$. lindbergii have numerous differences which will be discussed elsewhere. In Breidleria Hedenäs left Hypnum pratense and close EastAsian H. erectiusculum Sull. et Lesq. However, Hypnum at present is too heterogeneous to consider Breidleria (as well as Pseudostereodon) to be a good segregate, though further splitting of Hypnum may resurrect Breidleria.

Distribution: The species is known from most boreal and north-temperate areas of the Northern Hemisphere, but in most of the areas it is a rare moss. In Altai it was found once in a mesic Betula forest, on soil.

Specimen examined: Gorno-Altaisk 400 m (35/49).

\section{DOUBTFUL RECORD}

Hypnum callichroum Brid. was reported for Altai by Krylov (1924). The specimen was not found, but all so-named collections from South Siberia were found to be $H$. plicatulum, so we doubt that H. callichroum occurs in South Siberia.

\section{Callicladium Crum}

This genus was established by Crum (1971) to accommodate one widespread north-temperate and hemiboreal species, Callicladium haldanianum. For a long time it was placed in Heterophyllium, due to the somewhat complanate habit, conspicuous groups of thin-walled alar cells, and autoicous sexual condition. However this position was found not appropriate because of thinwalled alar cells. Essential differences from Hyp- 


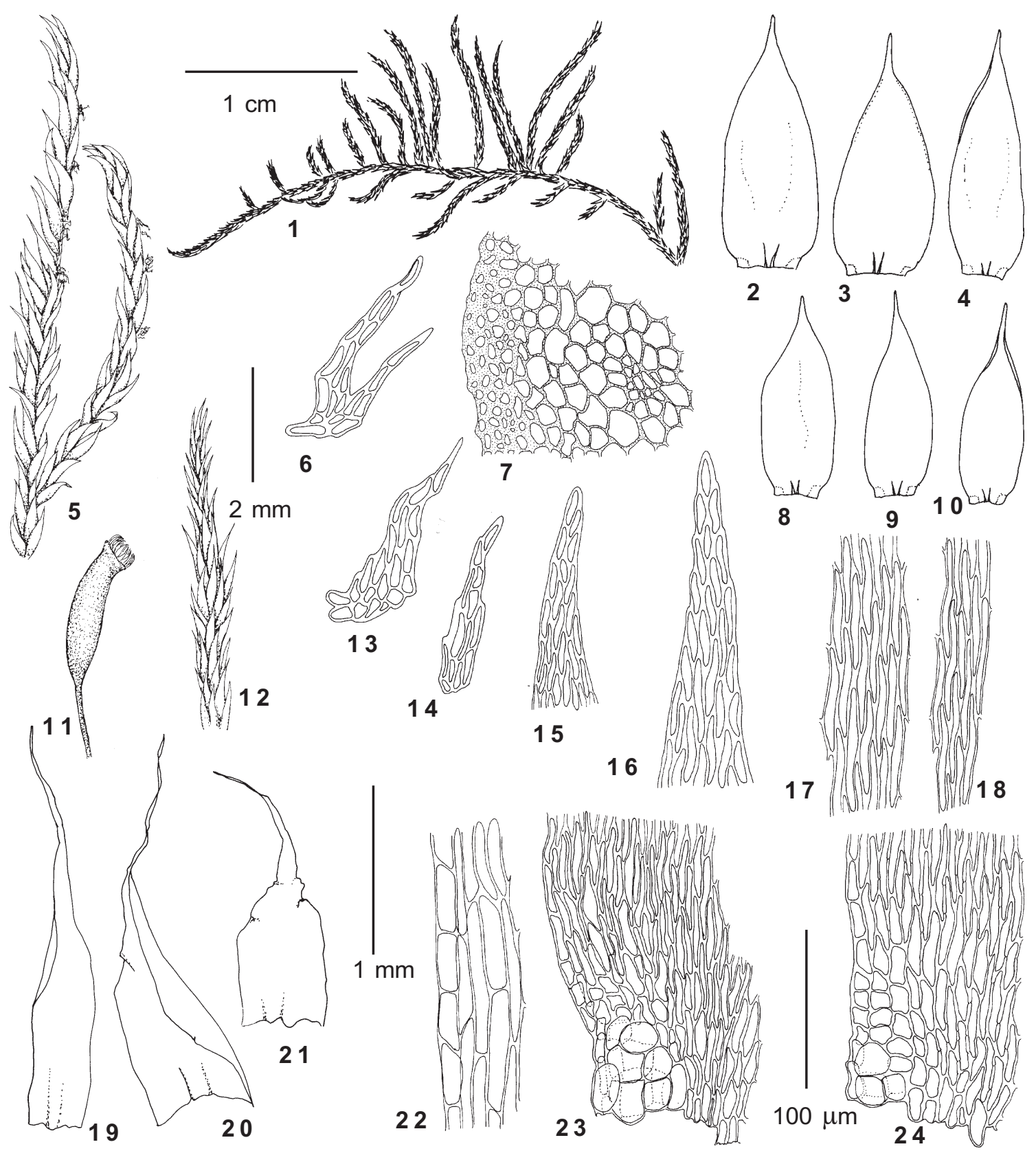

Fig. 60. Callicladium haldanianum (Grev.) Crum (from Klyk Pass $700 \mathrm{~m}$ Ignatov 0/636): 1 - habit; 2-4 - stem leaves; 5, 12 - shoot ends, showing variations; 6, 13-14 - pseudoparaphyllia; 7 - stem cross-section; 8-10 - branch leaves; 11 - capsule; 15-16 - upper laminal cells of stem leaves; 17-18 - middle laminal cells of stem leaves; 19-21 - perichaetial leaves; 22 - alar cells of perichaetial leaf; 23-24 - alar cells of stem leaves. Scale bars: $1 \mathrm{~cm}-\mathrm{for} 1$; $2 \mathrm{~mm}$ - for $5,11-12 ; 1 \mathrm{~mm}$ - for 2-4, 8-10, 19-21; $100 \mu \mathrm{m}$ - for $6-7,13-18,22-24$.

num include subjulaceous branches and \pm straight leaves with entire margins. However some forms of $H$. cupressiforme (especially var. subjulaceum and transitional forms between var. subjulaceum and var. filiforme) have a general appearance very close to that of Callicladium and they are easy to confuse. Their differences include sexual conditions (autoicous in Callicladium, dioicous in $H$. cupressiforme) and thin-walled alar cells in $\mathrm{Cal}$ licladium (porose in most leaves H. cupressiforme var. subjulaceum, though in some leaves the alar groups consist of mostly translucent and not 

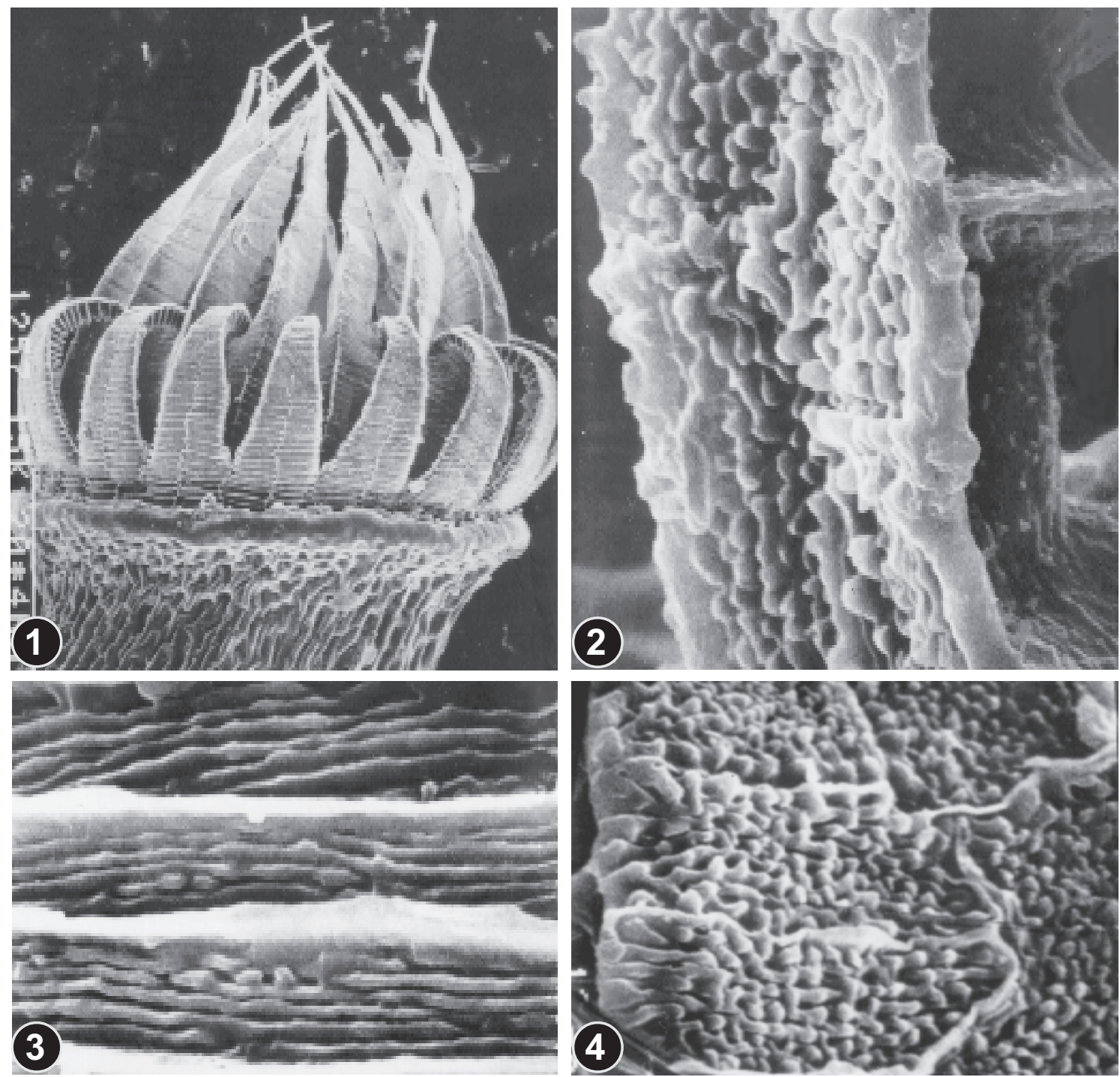

Fig. 61. Callicladium haldanianum (Grev.) Crum (from Yailyu, $450 \mathrm{~m}$, Ignatov, 0/1521): 1 - peristome (200×); 2 - side view of exostome tooth in upper part $(5300 \times)$; 3 - outer surface of exostome tooth in lower part $(5600 \times)$; $4-$ outer surface of exostome tooth in transition zone $(4400 \times)$.

especially porose cells). Similarity with the Hypnum cupressiforme-group (Hypnum sect. Hypnum) includes also non-plicate perichaetial leaves, which in all other sections of Hypnum are plicate. Therefore the generic segregation of Callicaldium poses a question about the further splitting of Hypnum.

Callicladium haldanianum (Grev.) Crum, Bryologist 74: 167. 1971. - Hypnum haldanianum Grev., Ann. Lyc. Nat. Hist. NY 1: 275. 1825. - Heterophyllium haldanianum (Grev.) Kindb., Canad. Rec. Sci. 6: 72. 1894.

Figs. $60 \& 61$

Plants large, in green to yellow-green glossy tufts. Stem prostrate, to $6 \mathrm{~cm}$ long; without hyalodermis; subjulaceous except distinctly complanate and always slightly arcuate-ascending ti ps; \pm regularly pinnatebranched, branches 5-10(-15) mm long, subjulaceous. Pseudoparaphyllia narrow-lanceolate, entire or with few teeth. Axillary hairs 5-6-celled, 120-140 $\mu \mathrm{m}$ long, apical cell 45-50 × $8 \mu \mathrm{m}$. Stem leaves straight, 1.4-1.7 $\times 0.5-0.6 \mathrm{~mm}$, ovate-lanceolate, concave; margins entire, recurved in the upper $2 / 3$; branch leaves 1.0-1.1 $\times 0.3-0.4 \mathrm{~mm}$. Laminal cells 60-85 × 5-7 (4-5.5/11.5) $\mu \mathrm{m}$. Alar cells differentiated, forming a well-delimited excavate group with few, large, \pm thin-walled, \pm isodiametric cells, about $20-25 \mu \mathrm{m}$ in diameter, which are surrounded by 2 rows of smaller isodiametric cells.

Autoicous. Sporophytes frequent. Perichaetial leaves to $3.0 \times 0.8 \mathrm{~mm}$, straight, smooth, abruptly 


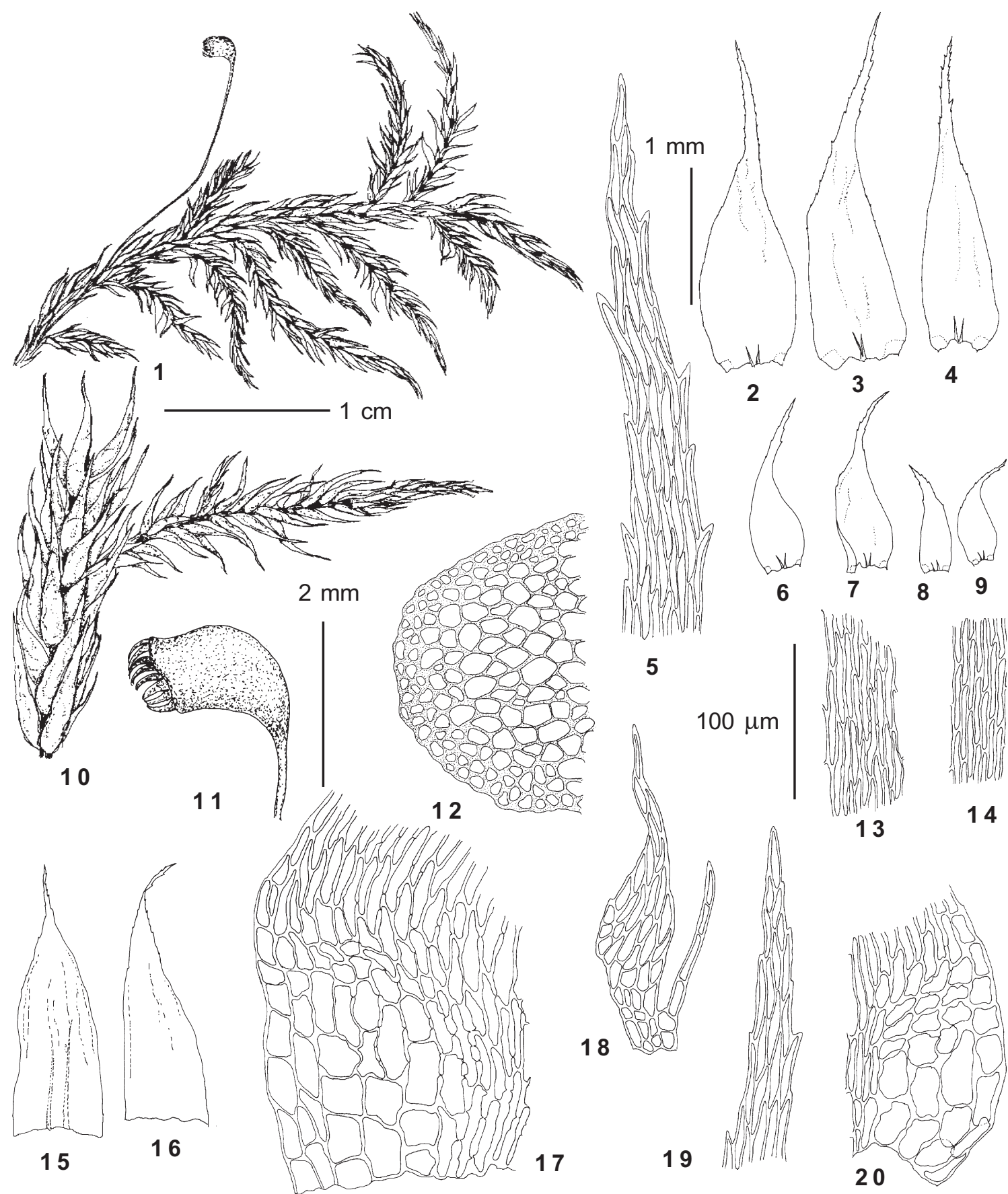

Fig. 62. Heterophyllium affine (Hook. ex Kunth) Fleisch. (from Bolshoye Istyube Creek $470 \mathrm{~m}$ Ignatov 0/1181): 1 - habit; 2-4-stem leaves; 5 - upper laminal cells of stem leaf; 6-9-branch leaves; 10 - portion of stem with branch; 11 - capsule; 12 - stem cross-section; 13 - middle laminal cells of stem leaf; 14 -middle laminal cells of branch leaf; 15 , 16 - perichaetial leaves; 17 - alar cells of stem leaf; 18 - pseudoparaphyllium; 19 - upper laminal cells of branch leaf; 20 - alar cells of branch leaf. Scale bars: $1 \mathrm{~cm}$ - for $1 ; 2 \mathrm{~mm}$ - for 10-11; $1 \mathrm{~mm}$ - for 2-4, 6-9, 15-16;100 $\mu \mathrm{m}-$ for 5 , 12 14, 17-20. 
acuminate, with indistinct costa. Seta 1.5-2.5 cm. Capsule to $2.5 \mathrm{~mm}$ long, chestnut-brown, curved in the upper part. Operculum high-conic to shortly obliquely rostrate. Exostome teeth ca. $0.70 \mathrm{~mm}$ long, gradually tapered, entire; in the lower part imperfectly striolate, with smooth cristae; in the middle papillose in extensive part; in the upper part \pm densely papillose; dorsal trabeculae low, margin not incrassate; ventral trabeculae smooth. Endostome $0.60 \mathrm{~mm}$ long, basal membrane $0.20 \mathrm{~mm}$ high; segments rather narrow and perforate; cilia nodose. Spores 15-17 $\mu \mathrm{m}$.

Distribution: Callicladium haldanianum has been reported from almost all regions of boreal and temperate Holarctic. However, many reports from northern and high-mountain localities are probably based on misidentifications of Hypnum cupressiforme var. subjulaceum. According to our observation, $C$. haldanianum is a very common epixylic species in deciduous and southern boreal forests, becoming much rarer and disappearing in the northern taiga. It is absent also in xeric regions of Central Asia, like Tian-Shan and Pamir Mts. and Mongolia. In China it occurs mostly in oceanic provinces. In Altai $C$. haldanianum is a rare moss restricted to the lower elevations in vicinity of Teletzkoye Lake, a region with especially wet and mild climate. It grows on rotten logs, stumps and tree bases.

Specimens examined: Artybash $450 \mathrm{~m}$ (Zolotukhin 25.IV.1977); Bolshoye Istyube Creek $470 \mathrm{~m}$ (18/14a); Chiri Creek, 0.5 km upstream $450 \mathrm{~m}$ (17/12; 17/13); Klyk Pass 700 m (0/636); Kumzir 500 m (Zolotukhin 22.IV.1977); Yailyu $450 \mathrm{~m}(0 / 1521), 500 \mathrm{~m}(0 / 1522)$.

Heterophyllium (Schimp.) C. Müll. ex Kindb.

The placement of Heterophyllium in Sematophyllaceae was argued by the deep-colored concave alar group. However this character is not impossible for Hypnaceae (cf. Hypnum cupressiforme var. subjulaceum, H. bambergeri, etc.). Also, Heterophyllium was left by Tan \& Buck (1989) in Sematophyllaceae due to its relation to Gammiella, Aptychella, Pylaisiopsis and Isocladiella. However the latter four genera have peristomes strongly different from the hypnoid type (straight central line and heavily papillose exostome, etc.), and also Aptychella has filiform gemmae and Isocladiella a subulate operculum. Therefore we doubt about the placement of Heterophyllium near these genera in Sematophyllaceae.

Heterophyllium includes several rather closely related species, distributed in tropical to temperate regions of both hemispheres. Plants are autoicous and characteristically golden-yel- low; leaves distinctly serrate above; and alar cells dark-colored, forming an excavate group.

Heterophyllium affine (Hook. ex Kunth) Fleisch., Musci Fl. Buitenz. 4: 1177. 1919. - Hypnum affine Hook. ex Kunth, Syn. Pl. Itin. Plag. Aequin. Orbis Novi 1: 63. 1822. - Heterophyllium nemorosum (Koch ex Brid.) Kindb., Canad. Rec. Sci. 6: 72. 1894.

Figs. $62 \& 63$

Plants medium-sized to robust, yellow to brownish with age. Stem $7 \mathrm{~cm}$ long; without hyalodermis, with central strand; regularly pinnate-branched, branches to $10 \mathrm{~mm}$ long, spreading and arcuate, the mat thus appearing rather thick. Pseudoparaphyllia variable, broad, triangular, narrow lanceolate to filamentous. Axillary hairs 4-7-cells, ca. $150 \mu \mathrm{m}$ long, apical cell about $45 \times 8 \mu \mathrm{m}$. Stem leaves 2.2-2.8 $\times 0.6-0.7$ $\mathrm{mm}$, lanceolate, \pm abruptly acuminate, coarsely serrate above, somewhat plicate, gradually narrowed to the base, orange at insertion. Branch leaves 0.8-1.4 $\times 0.3$ $0.4 \mathrm{~mm}$. Laminal cells $40-60 \times 7(4-5 / 2-3) \mu \mathrm{m}$; alar cells subquadrate, porose and thick-walled, forming a transparent to colored, sharply delimited $\pm \mathrm{ex}^{-}$ cavate group.

Autoicous. Perichaetial leaves to $2.0 \times 0.7 \mathrm{~mm}$, erect, smooth, serrate above; costa double or lacking. Seta 2-3 cm, red-brown. Capsules ca. $20 \mathrm{~mm}$ long, inclined, not furrowed. Operculum conic. Annulus of 1 row of round cells, deciduous. Exostome teeth $0.5 \mathrm{~mm}$ long, gradually tapered in transition zone, entire; perfectly striolate below; in the middle densely papillose on many plates; in the upper part moderately papillose; dorsal trabeculae and incrassate margin with low papillae; ventral trabeculae sparsely low-papillose. Endostome as high as the teeth, basal membrane $0.23 \mathrm{~mm}$ high, segments broad and perforate, cilia nodose. Spores 13-15 $\mu \mathrm{m}$.

Heterophyllium affine is easy to recognize by the pure rich-golden color of plants, unusual for boreal regions. Most collections in Altai were made with abundant sporophytes.

Distribution: Heterophyllium affine occurs in temperate regions of North America, northern Latin America including the West Indies (in lower altitudes at higher elevations), and in a few scattered localities in mountains throughout Eurasia: Germany, Romania, Austria, Italy, Ukrainiain Carpatians, Caucasus, Altai and Sayan in South Siberia, Russian Far East, Bhutan in Himalayas, Sichuan and Hunan in mainland China, Taiwan, and Japan. In Altai $H$. affine grows only around Teletzkoye Lake, mostly in deep wet canyons, on rocks and rotten logs, often forming pure extensive mats.

Specimens examined: Bayas Creek, in middle course 850 m (16/2); Bolshoye Istyube Creek $470 \mathrm{~m}(0 / 1181 ; 0 / 1183)$; Kamga Creek, 10 km upstream $530 \mathrm{~m}(0 / 1179), 550 \mathrm{~m}(0 /$ 1180; 0/95), $580 \mathrm{~m}$ (0/1182); Yailyu $450 \mathrm{~m}(0 / 638)$. 

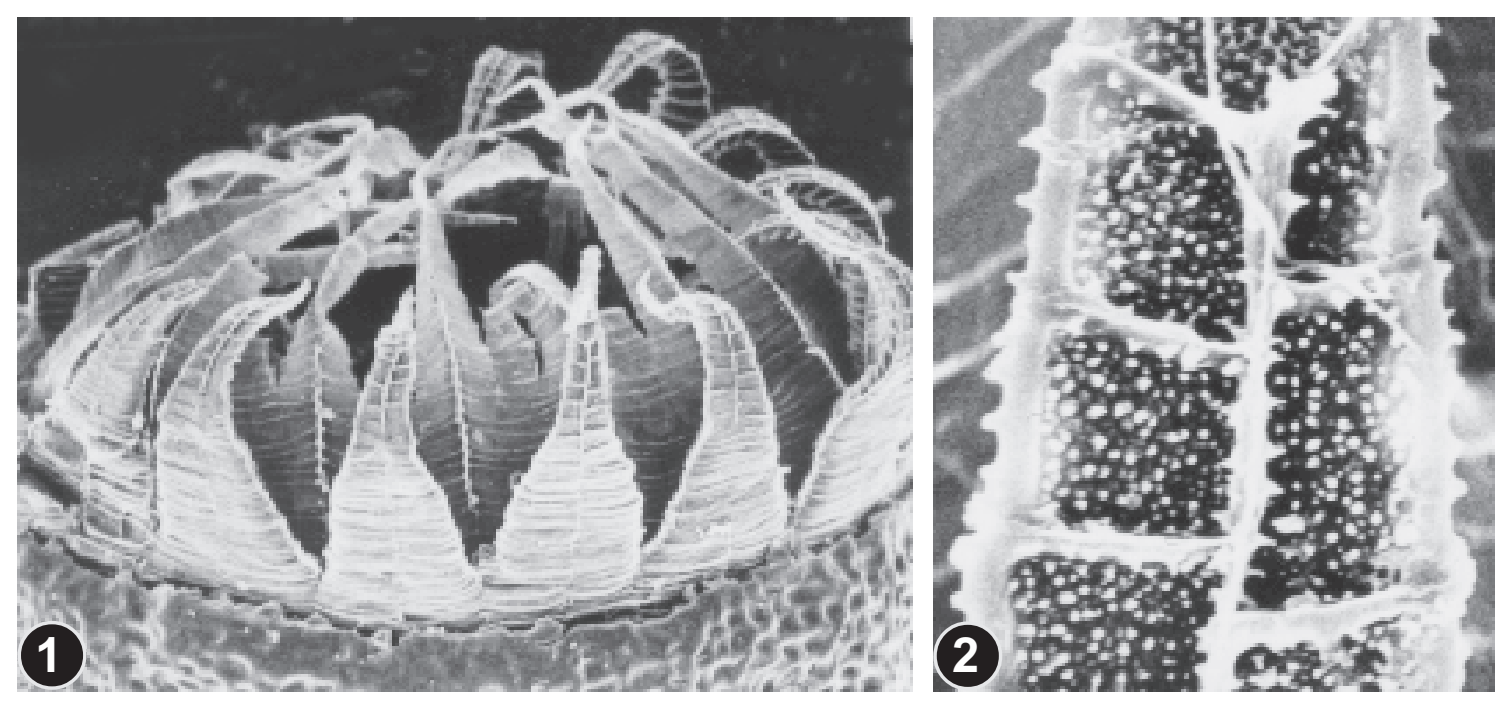

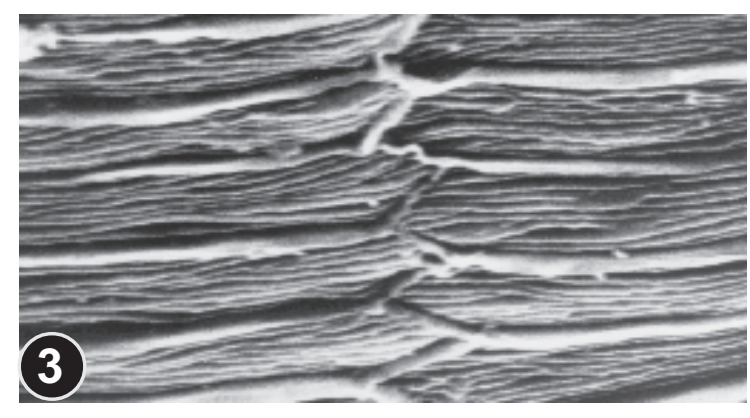

Ptilium De Not.

The monotypic genus Ptilium is close to Hypnum, but differs in very dense and regularly plumose branching, erect-ascending growth, distinctly differentiated stem and branch leaves, linear or longly acuminate pseudoparaphyllia, and deeply plicate, circinate leaves.

Ptilium crista-castrensis (Hedw.) De Not., Cronac. Briol. Ital. 2: 17. 1867. - Hypnum crista-castrensis Hedw., Sp. Musc. 287. t. 76, f. 1-4. 1801.

Figs. $64 \& 65$

Plants large, yellow-green. Stem erect or ascending, ca. $10 \mathrm{~cm}$ long; without hyalodermis, with central strand; densely plumose-branched, branches to $10 \mathrm{~mm}$ long; densely foliate. Pseudoparaphyllia longlanceolate. Axillary hairs 4-5-celled, ca. $150 \mu \mathrm{m}$ long, apical cell 40-50 $\times 8 \mu \mathrm{m}$. Stem leaves falcate-secund, 2.2-2.5 $\times 0.9-1.0 \mathrm{~mm}$, lanceolate, gradually acuminate, strongly curved to nearly rounded, deeply plicate, serrulate above, a little narrowed at base. Branch leaves 1.4-1.6 × 0.2-0.3 mm. Laminal cells 50-90 × 4$6(2-3 / 2-3) \mu \mathrm{m}$, thick-walled; alar cells few, shortrectangular to subquadrate.

Dioicous. Sporophytes rare. Inner perichaetial leaves to $3.2 \times 0.5 \mathrm{~mm}$, erect or with a little reflexed
Fig. 63. Heterophyllium affine (Hook. ex Kunth) Fleisch. (from Kamga Creek 530 m Ignatov 0/95): 1 peristome $(220 \times) ; 2$ - outer surface of exostome in upper part $(2200 \times) ; 3-$ outer surface of exostome in lower part $(2200 \times)$.

apex, ecostate, plicate, serrulate above. Seta 2-4 cm. Capsule $2.5 \mathrm{~mm}$ long, curved when open, slightly furrowed. Operculum conic, with short truncate beak. Annulus of one row of small round cells, deciduous. Exostome teeth to $0.8 \mathrm{~mm}$ long, striolate (with papillose cristae) below; in the middle densely papillose; in the upper part sparsely papillose; dorsal trabeculae and incrassate margin with regular highconical papillae; ventral trabeculae sparsely tinyspinulose. Endostome $0.8 \mathrm{~mm}$ long, basal membrane $0.35 \mathrm{~mm}$ high; segments broad and perforate; cilia 3-4, nodose (rarely appendiculate). Spores 12-14 $\mu \mathrm{m}$.

Distribution: Ptilium crista-castrensis is a widespread circumboreal species. In Altai it occurs in wet mossy conifer forests, and does not exceed the tree-line in high mountains. It grows on litter among other mosses, on rotten logs, and sometimes on rocks.

Specimens examined: Bolshoye Istyube Creek $470 \mathrm{~m}$ (0/2089; 18/136); Booshkon Creek, upper course $1865 \mathrm{~m}$ (Zolotukhin 2.VII.1990); Itykul Lake $1800 \mathrm{~m}$ (Makhatkov \& al. 2.VIII.1978); Kairu Creek, 8 km upstream $1000 \mathrm{~m}$ (15/155); Kamga Creek, 11 km upstream $580 \mathrm{~m}$ (0/1200); Kayakkatuyarykskij Creek $1760 \mathrm{~m}$ (8/76); Kishte $440 \mathrm{~m}$ (Zolotukhin 11.VII.1988); Kobiguayuk Creek 2240 m (0) 605); Kuba Creek, at mouth $500 \mathrm{~m}$ (Voshchilko 13.VII.1970); Ozernaya Creek $2150 \mathrm{~m}$ (Zolotukhin \& al. 9.VIII.1976); Seminskij Pass $1750 \mathrm{~m}$ (Makarov \& al. 18.VI.1972); Tamanel Peak 1800 m (34/94); Yailyu 700 m (0/606). 


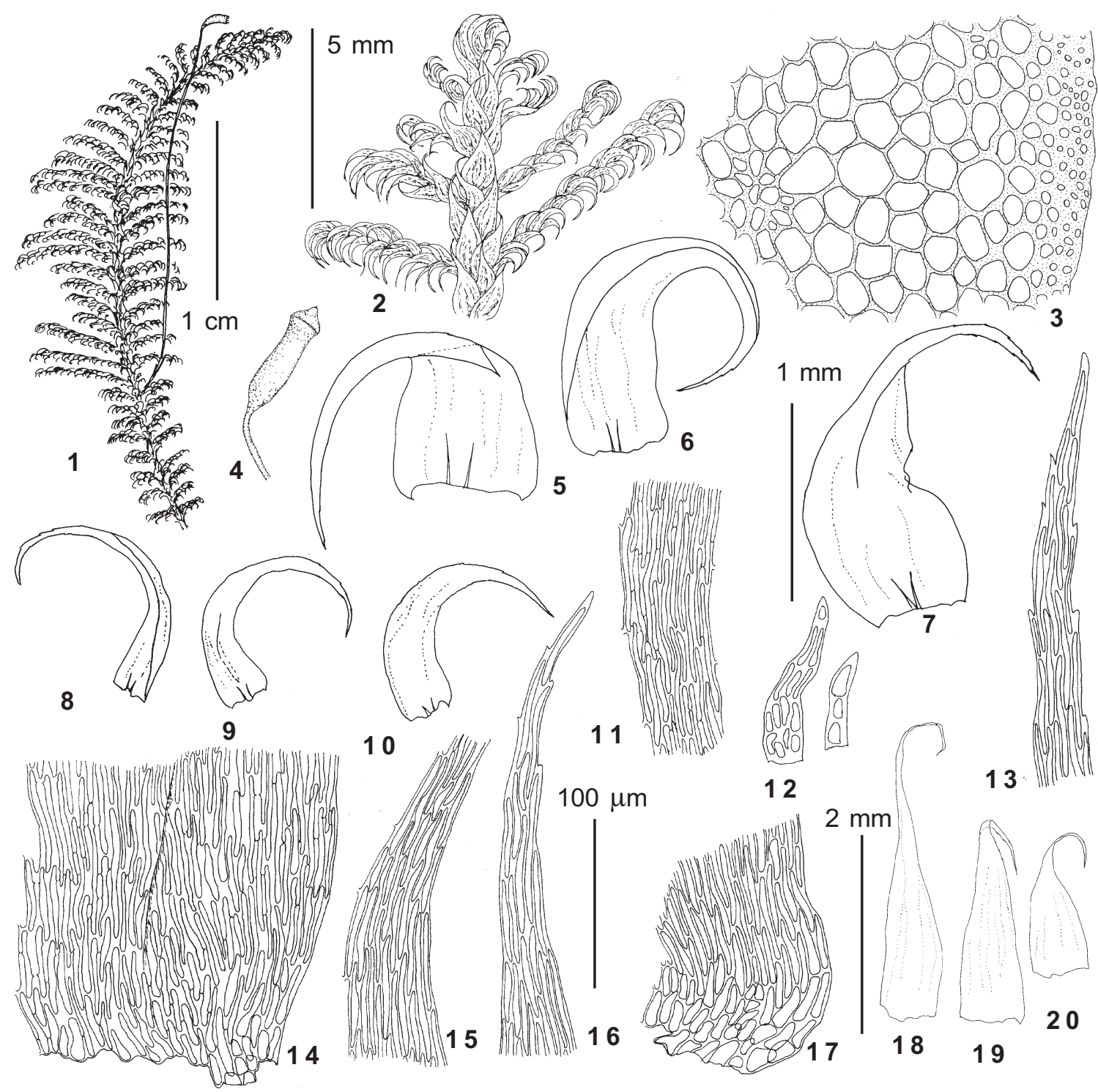

Fig. 64. Ptilium crista-castrensis (Hedw.) De Not. (from Kayakkatuyarykskij Creek 1760 m Ignatov 8/76): 1-2 habit; 3 - stem cross-section; 4 - capsule; 5-7 - stem leaves; 8-10 - branch leaves; 11- middle laminal cells of stem leaf; 12 - pseudoparaphyllia; 13 - upper laminal cells of stem leaf; 14 - alar cells of stem leaf; 15 - middle laminal cells of branch leaf; 16 - upper laminal cells of branch leaf; 17 - alar cells of branch leaf; 18-20 - perichaetial leaves. Scale bars: $1 \mathrm{~cm}$ - for $1 ; 5 \mathrm{~mm}$ - for 2, 4; $2 \mathrm{~mm}$ - for 18-20; $1 \mathrm{~mm}$ - for 5-10; $100 \mu \mathrm{m}$ - for 3, 11-17.

Gollania Broth.

Gollania was revised by Higuchi (1985), who recognized 17 species, occurring in Himalayas,China,Japan,Phili ppines, Russian Far East, and G. turgens penetrating to NW of North America and South Siberia. Later two more species were described from China (Higuchi \& Wu, 1995; Higuchi \& Long, 1996).

The genus has an ambiguous position, since some species have a short costa and smooth laminal cells and are similar to Hypnum, while other species with a long double costa, serrate leaf margins, prorate cells and \pm reniform leaves demonstrate a closer resemblance to Rhytidiadelphus and Macrothamnium of Hylocomiaceae (Higuchi, 1985). The latter family has been delimited by Rohrer (1985a,b) for genera which share various combinations of the following apomorphic characters (1) reticulate peristome ornamentation; (2) broad perforation of endostome segments; (3) sympodial growth; (4) presence of paraphyllia; (5) differentiated stem and 

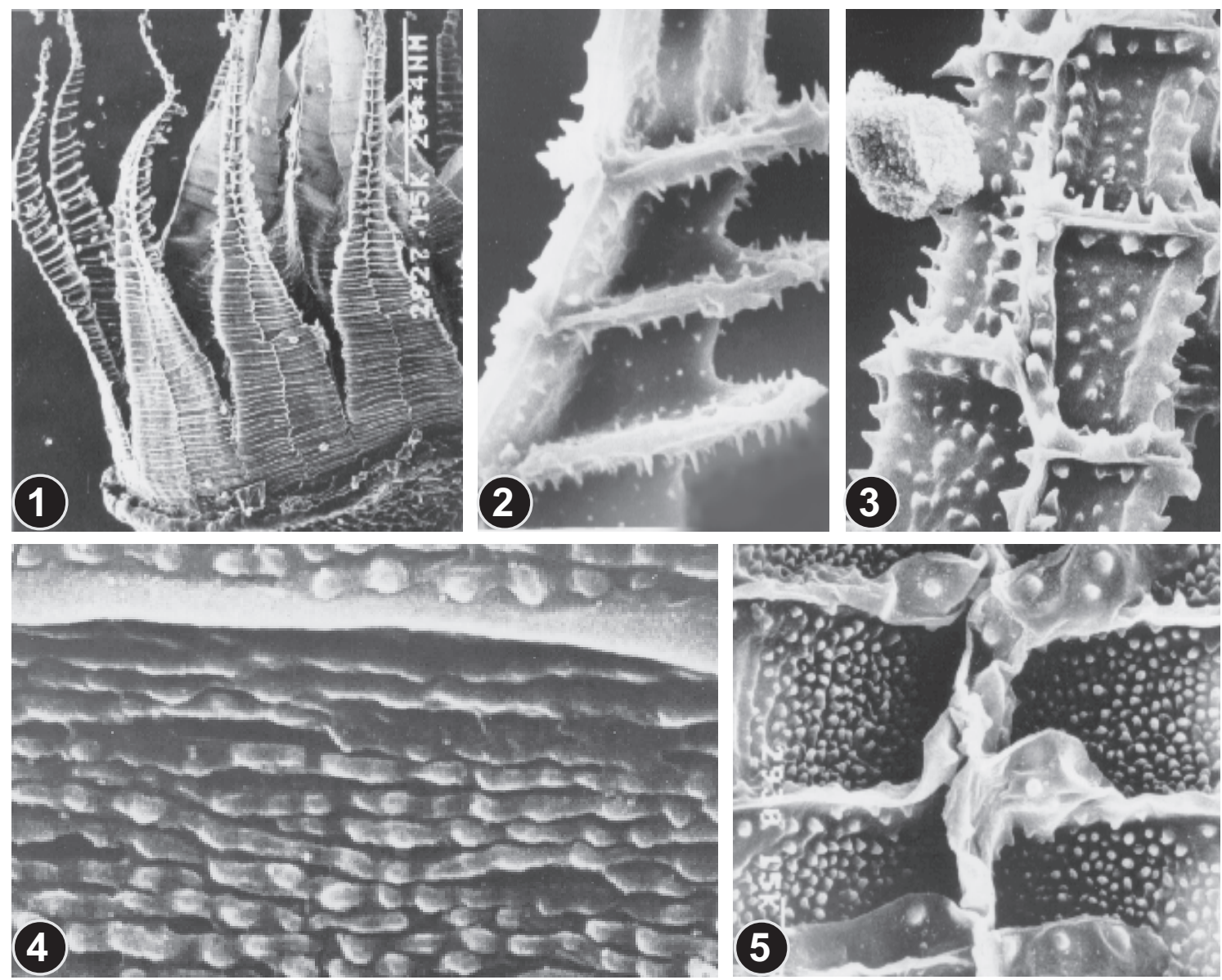

Fig. 65. Ptilium crista-castrensis (Hedw.) De Not. (from South Siberia, Irkutsk Province, leg. L. Voronaj 1.VIII.1951, MHA): 1 - peristome (150×); 2 - side view of exostome tooth in upper part, showing echinate-papillose inner trabeculae $(3000 \times) ; 3$ - outer surface of exostome tooth in upper part $(3000 \times) ; 4-$ outer surface of exostome tooth in lower part $(10000 \times) ; 5$ - outer surface of exostome tooth in transition zone $(2300 \times)$.

branch leaves; (6) sharply serrate leave margins; (7) costa double but long or single and branched; (8) long laminal cells with prorate ends. Some species of Gollania (G. ruginosa (Mitt.) Broth., G. varians (Mitt.) Broth., etc.) fit the characters $6,7,8$, almost the same as Rhytidiadelphus squarrosus. However Gollania is different from Rhytidiadelphus in: (1) plagiotropic growth; (2) \pm homomallous leaves; (3) rhizoids just below the leaf insertion on stems and branches, while in Rhytidiadelphus rhizoids are mostly axillary on branch tips and on stems rhizoids are restricted to the base of branches or branch initials; (4) narrow perforation of endostome segments.

Gollania turgens (C. Müll.) Ando, Bot. Mag. Tokyo 79: 769. 1966. - Cupressinia turgens C. Müll., Nuovo Giorn. Bot. Ital., n. s., 5: 196. 1898.

Fig. 66
Plants medium-sized, yellow-green, somewhat glossy. Stem prostrate, ca. $5 \mathrm{~cm}$ long; with central strand, without hyalodermis; regularly pinnatebranched, branches $8 \mathrm{~mm}$ long, \pm complanate. Pseudoparaphyllia narrowly triangular. Axillary hairs 5-celled, often all colored, $120 \mu \mathrm{m}$ long, apical cell $35-45 \times 10-12 \mu \mathrm{m}$. Stem leaves slightly falcate, $2.2-$ $2.5 \times 0.6-0.8 \mathrm{~mm}$, ovate-lanceolate, gradually acuminate, slightly narrowed to the base, plicate; costa double, to $1 / 3$ the leaf length; margins serrate above, subentire and recurved below. Branch leaves 1.4$1.7 \times 0.3-0.5 \mathrm{~mm}$, widest at ca. $2 / 5$ of leaf length. Laminal cells (30-) 40-60 × 5-7 (3-4/2-3) $\mu \mathrm{m}$, thickwalled, strongly prorate; alar subquadrate cells few, gradually grading to upper cells, but abruptly delimited from the central basal cells.

Sporophytes not found in Altai. SEM pictures of the exostome teeth have been published by Higuchi (1985); the teeth in lower part has papillose cristae similar to those of Ptilium. 


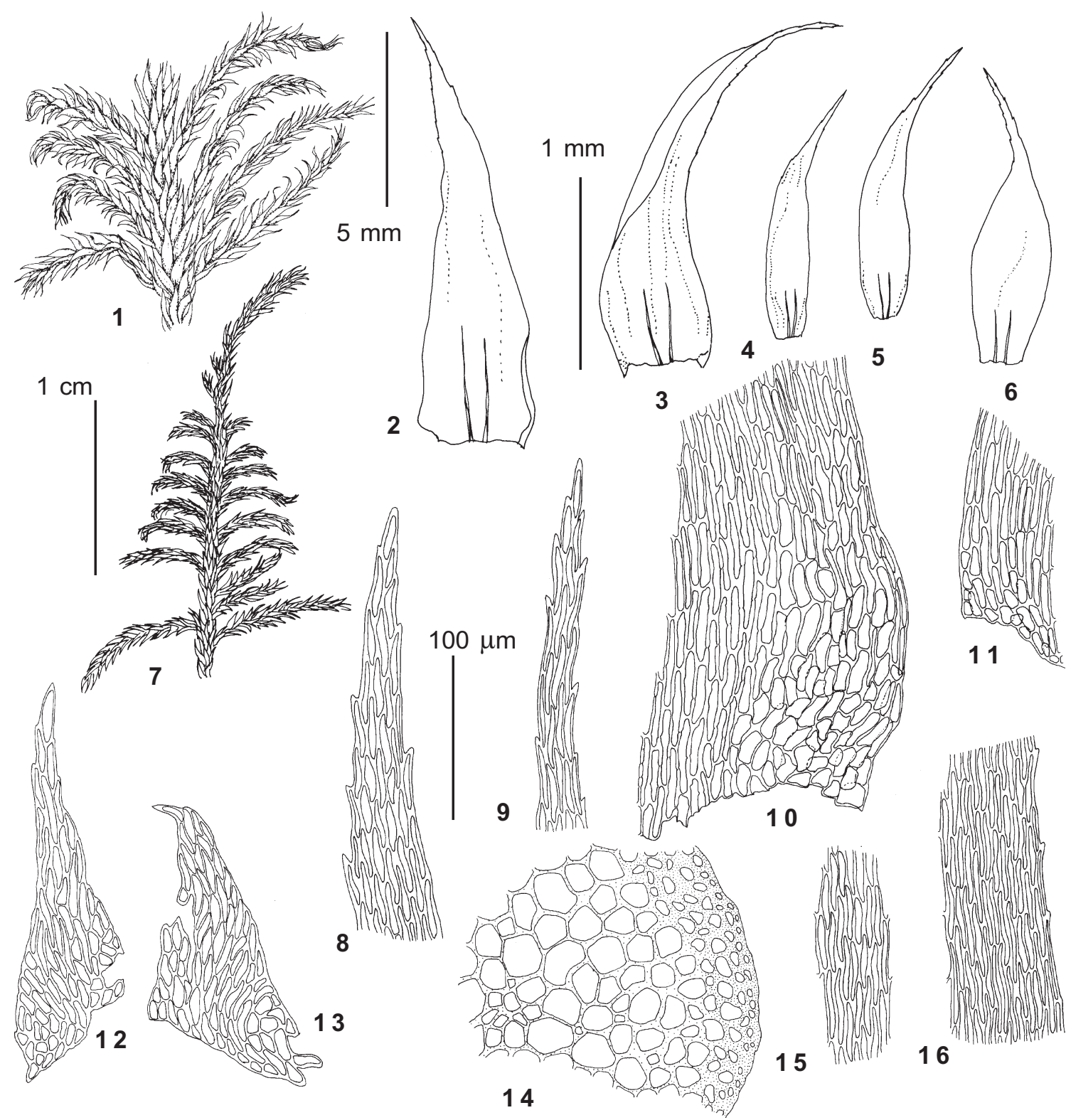

Fig. 66. Gollania turgens (C. Muell.) Ando (from Kairu Creek, 8 km upstream $1000 \mathrm{~m}$ Ignatov 15/2): 1-7 - habit; 2-3 - stem leaves; 4-6 - branch leaves; 8 - upper laminal cells of stem leaf; 9 - upper laminal cells of branch leaf; 10 - alar cells of stem leaf; 11 - alar cells of branch leaf; 12-13 - pseudoparaphyllia; 14 - stem cross-section; 15 middle laminal cells of branch leaf; 16 - middle laminal cells of stem leaf. Scale bars: $1 \mathrm{~cm}-$ for $7 ; 5 \mathrm{~mm}-$ for $1 ; 1$ $\mathrm{mm}$ - for $2-6 ; 100 \mu \mathrm{m}$ - for $8-16$.

Altaian plants of Gollania turgens have the habit of large Hypnum with slightly falcate and plicate leaves. Higuchi (1985) mentioned that stem leaves are typically strongly falcate, but Alaskan plants can also have nearly straight leaves.

Distribution: A distribution map of this species was published by Higuchi (1985). It is known from a number of places in Alaska and northwestern Canada, but in Asia G. turgens has very scattered localities: 2 - in
Japan, 10 - in China (Schensi, Kansu, Sichuan, Yunnan), 2 - from Nepal, 1 - from Baikal area, 1 - in Eastern Sayan. In Altai G. turgens was collected only once, on a wet rock outcrop near the bottom of a narrow valley.

Specimen examined: Kairu Creek, 8 km upstream 1000 $\mathrm{m}(15 / 2)$.

Taxiphyllum Fleisch.

This genus is usually placed near Isopterygium s.1., Herzogiella, and Plagiothecium. Re- 


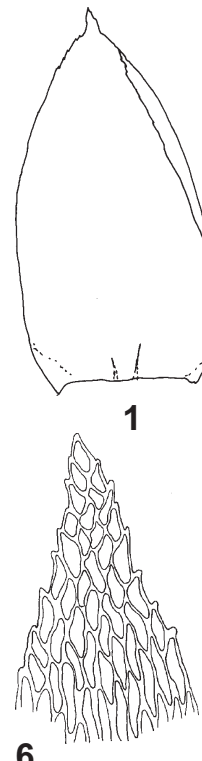

6

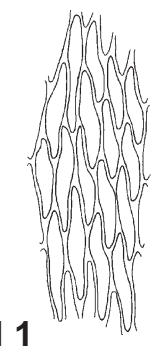

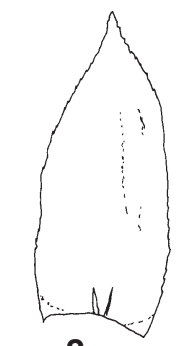

2

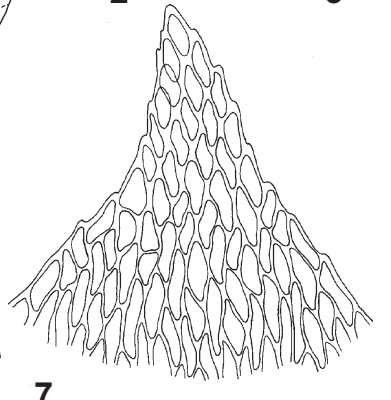

7

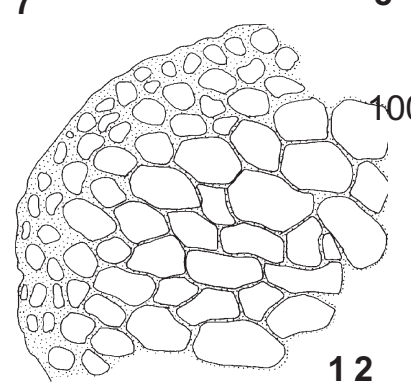

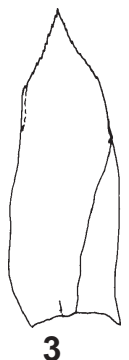
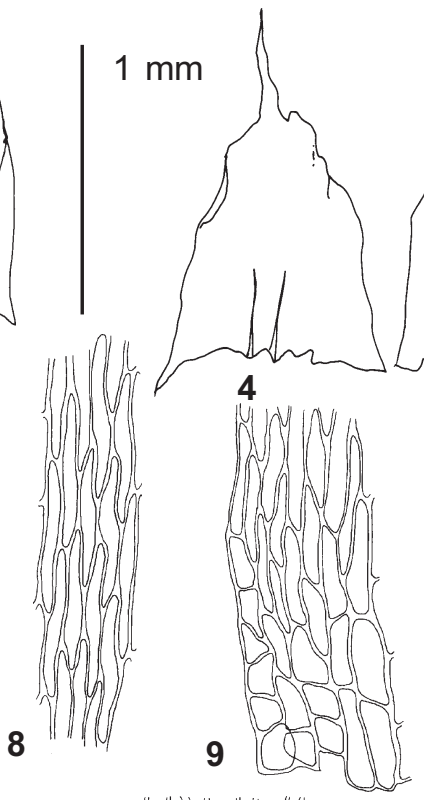

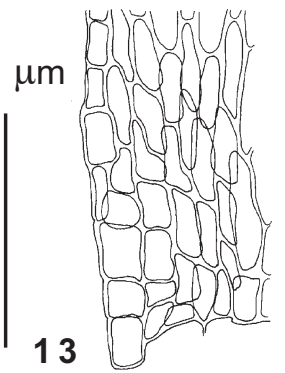

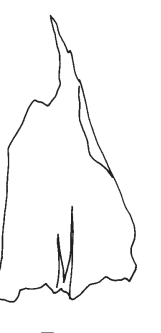

5

$5 \mathrm{~mm}$

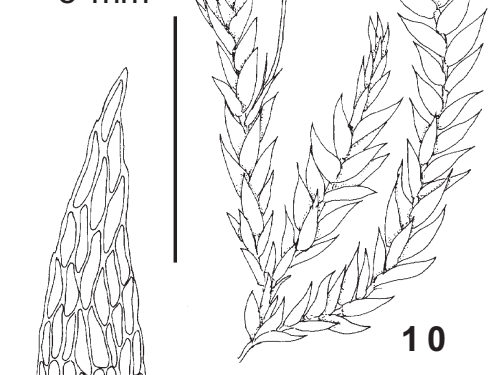

Fig. 67.Taxiphyllum wissgrillii (Garov.) Wijk \& Marg. (from Karagai 440 m Ignatov 0/1258): 1-3- leaves; 4-5 - perichaetial leaves; 6-7 - upper laminal cells; 8, 11 - middle laminal cells; 9,13 - alar cells; 10 - habit; 12 - stem cross-section; 14-15 - pseudoparaphyllia. Scale bars: $5 \mathrm{~mm}$ - for $10 ; 1 \mathrm{~mm}$ - for 1-5; $100 \mu \mathrm{m}$ - for 6-9, 11-15.

cent raising of the weight of characters of pseudoparaphyllia, rhizoid topography and karyotypes, however, demonstrates that Taxiphyllum has little in common with the genera without pseudoparaphyllia (Herzogiella, Isopterygiopsis and Plagiothecium). The genus includes about 20 species in the tropical and temperate zones and is probably not monophyletic and need a further worldwide revision (at least exostome ornamentation was found different in some species studied).

Taxiphyllum wissgrillii (Garov.) Wijk \& Marg., Taxon 9: 191. 1960. - Hypnum wissgrillii Garov., Bryol. Austr. Excurs. 79. 1840.

Figs. $67 \& 68$

Plants small to medium-sized, green to yellowbrown. Stem freely branched, ca. $6 \mathrm{~cm}$ (branches $6 \mathrm{~mm}$ ) when optimally developed, but usually less than $2 \mathrm{~cm}$, complanate, without hyalodermis, with central strand. Pseudoparaphyllia narrowly triangular or lanceolate. Axillary hairs 2-celled, $50 \mu \mathrm{m}$ long, apical cell ca. $40 \times 6$ $\mu \mathrm{m}$. Stem leaves straight, 1.0-1.5 ×0.5-0.7 mm, ovate, \pm shortly acute; costa short, double or forked; margins serrate above (teeth sometimes with recurved tips), subentire below. Branch leaves 0.7-1.1 $\times 0.3-0.5 \mathrm{~mm}$, ovate-lanceolate. Laminal cells 60-100 × 7-9 (6-8/1) $\mu \mathrm{m}$, in optimally developed forms prorate on both ends and sometimes overlapping each other because lateral walls are not perpendicular to the lamina surface (in poorly developed forms cells smooth). Alar cells isodiametric, somewhat larger than those in the center of the base, irregularly positioned, so the margin at base appears somewhat eroded to toothed.

Dioicous. Sporophytes (many) found in one collection from Altai (on relatively dry log on bank of Teletzkoye Lake). Perichaetial leaves $1.0 \times 0.4 \mathrm{~mm}$, plicate. Seta 0.7-1.1 cm. Capsule ca. $1.5 \mathrm{~mm}$ long, inclined, slightly curved. Exostome teeth ca. 0.50$0.53 \mathrm{~mm}$ long, \pm gradually tapered, slightly serrulate to subentire above; in the lower part striolate, with smooth cristae; in the middle with short irregular vermicular cristae (often longitudinally oblique) sometimes intermixed with papillae; in the upper 

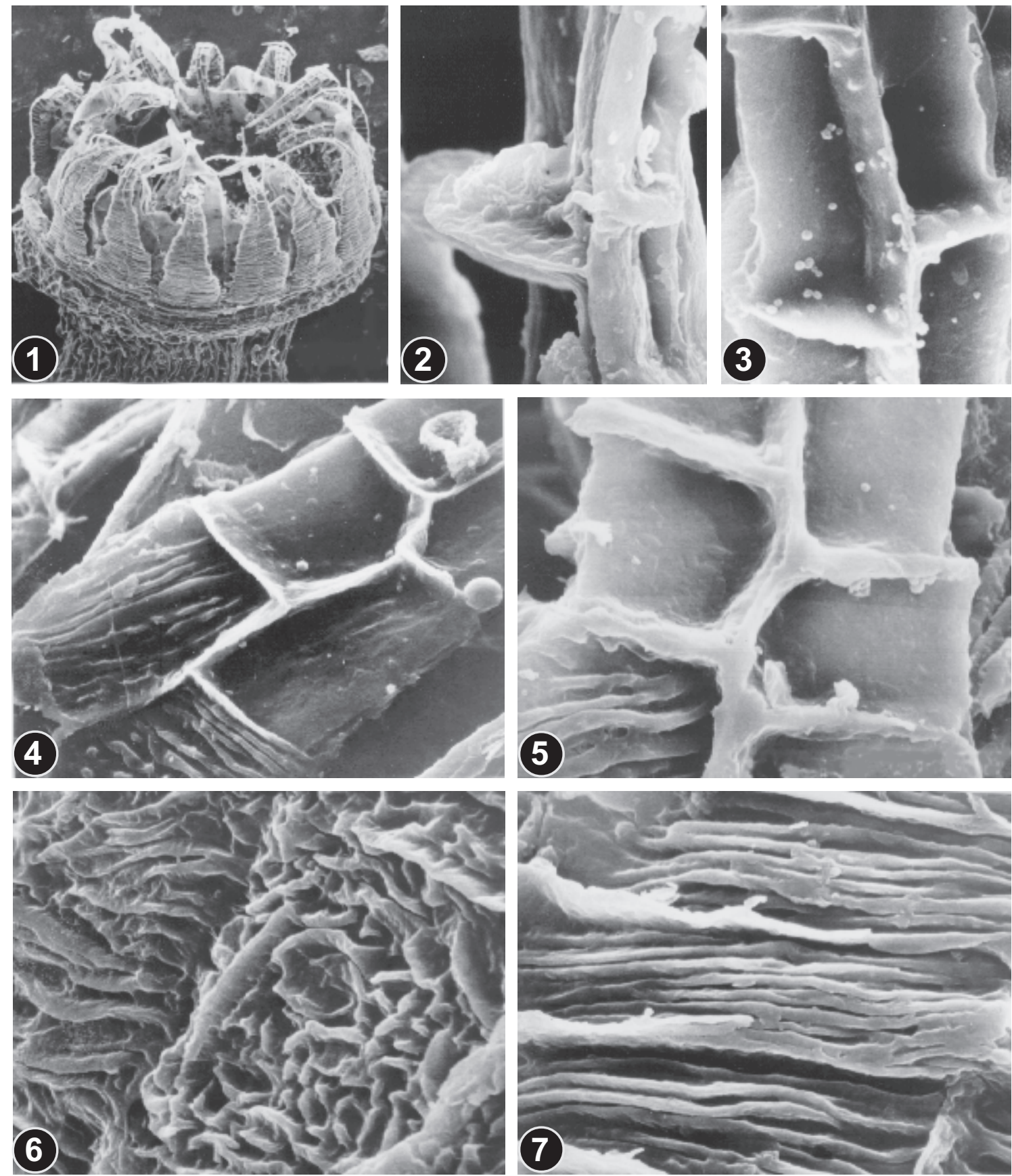

Fig. 68. Taxiphyllum wissgrillii (Garov.) Wijk \& Marg. (from Karagai $440 \mathrm{~m}$ Ignatov 0/1258): 1 - peristome $(150 \times) ; 2$ - side view of exostome tooth in upper part $(3900 \times) ; 3$ - outer surface of exostome tooth in upper part $(4400 \times)$; 4-5 - upter surface of exostome tooth in transition zone $(4-27504 ; 5-3600 \times)$; 6 - outer surface of exostome tooth just below transition zone $(5600 \times)$; 7 - outer surface of exostome tooth in lower part $(3300 \times)$.

part abruptly becoming smooth, with rare low papillae only on strongly incrassate dorsal trabeculae; margin non-incrassate; ventral surface and trabeculae smooth. Endostome $0.55 \mathrm{~mm}$ long, basal membrane $0.2 \mathrm{~mm}$ high; segments broad and perforate; cilia nodose. Spores. 12-16 um.

Most specimens of this species from northern Europe are sterile and represent a rather small procumbent form. Such plants occur also in Altai, especially in shady rock crevices, where 
scattered shoots can be collected. However, several collections differ in larger size, subjulaceous foliage, growth on rather dry rotten logs in diffuse shade, and sometimes in having sporophytes. These plants fit well the type of Isopterygium depressum var. subjulaceum Card. et Coppey, Bull. Soc. Bot. France 58: 198. 1911. (?isotype: pierres calcaires pres Nancy, France, 4 Mars 1911, leg. Coppey, H-BR!). Identical plants were seen from South Europe (Hungary, Italy) and Kazakhstan. However their taxonomic recognition seems unreasonable since (1) leaf shape and areolation of larger and smaller form are similar in essential features; (2) transitional forms have been observed in South Europe and Caucasus (in $\mathrm{H}$ ).

Distribution: This species has a mostly European distribution, known from nearly all countries and reaching to the east Ural Mts. and Caucasus. Outside Europe it has been reported from North Africa, Himalayas and Altai Mts. In Altai T. wissgrillii grows mostly on deeply shaded rocks (usually \pm calcareous schists), rarely occurring on dry logs among thick moss mats, in partial shade.

Specimens examined: Artybash $450 \mathrm{~m}$ (22/4); Ayukol $800 \mathrm{~m}$ (0/1253); Chemal Creek, $3 \mathrm{~km}$ upstream $450 \mathrm{~m}$ (34/106; 34/27); Derbogach $440 \mathrm{~m}(0 / 13)$; Elekmonar Creek, $8 \mathrm{~km}$ upstream $800 \mathrm{~m}(26 / 66)$; Karagai $440 \mathrm{~m}$ (0/1258; 0/276); Kobukhta $550 \mathrm{~m}(0 / 607), 600 \mathrm{~m}(0 /$ 1255); Kumzir $450 \mathrm{~m}(20 / 13 ; 20 / 27)$; Maima $350 \mathrm{~m}$ (35/47); Ok-Porok Creek, at mouth $450 \mathrm{~m}(0 / 1259$; 0 / 1260); Tura Creek, in middle course $1300 \mathrm{~m}(28 / 35)$; Ust-Sema $450 \mathrm{~m}$ (24/86); Yailyu $450 \mathrm{~m}$ (0/1263), 550 $\mathrm{m}(0 / 1257 ; 0 / 1261), 600 \mathrm{~m}(0 / 1256) ;$ Yurga $540 \mathrm{~m}$ $(0 / 1254)$

\section{Sematophyllaceae Broth.}

The family is a large and heterogeneous assemblage of tropical to temperate ecostate pleurocarps characterized by (1) angular cells often vesiculate-inflated; $(2)$ tendency to peristome reduction, including both exostome (teeth from cross-striolate to heavily papillose, with straight, often furrowed center line) and endostome (cilia, basal membrane and sometimes segments lacking). The family includes about 40 genera, and not in all of them are both gametophytic and sporophytic characters correlated with each other. Not rare the character either 1 , or 2 are considered enough to refer a moss to Sematophyllaceae.

Struckia C. Müll.

This genus includes one species with two subspecies. It is peculiar in lax areolation in leaf base, fragile branches, single peristome with a straight median line (with thickenings along the median line on the ventral surface of peristome). Tan \& Buck (1989) transfer Struckia from Sematophyllaceae (where it was placed by Brotherus, 1925) to Hypnaceae because of unusually lax areolation of leaves. Lax leaf areolation, fragile branches and rhizoids arising on leaf back could be interpreted as characters of Plagiotheciaceae, where Struckia was placed by Fleischer (1912). However lack of endostome and relatively short, blunt and strongly papillose exostome teeth are not known in any genera of both Hypnaceae and Plagiotheciaceae, while the similar pattern of peristome reduction is known in many genera of Sematophyllaceae. In some species of Sematophyllaceae, for example Brotherella recurvans from North America, we found rather fragile branches and rhizoid position similar to Struckia (mostly on the back of leaf at base). Sematophyllaceae are badly waiting for revision, and probably Struckia is not close to the main nucleus of this family, but the placement of this genus in Hypnaceae seems equally inappropriate. We leave here this problem for further studies. Moreover Siberian plants have never been found with sporophytes.

Struckia argentata (Mitt.) C. Müll. ssp. zerovii (Lazarenko) Tan, Buck et Ignatov, Lindbergia 16(3): 102. 1990. - Cephalocladium zerovii Lazarenko, Bot. Zhurn. AN URSR 3(3-4): 62. 1946.

Fig. 69

Plants rather small, in soft green to whitish-green \pm glossy mats. Stem prostrate, to $1 \mathrm{~cm}$ long, freely branched, julaceous, with some stoloniform rarely foliated axes. Many shoots ending in crown of small caducous leaves $0.3-0.5 \times 0.2 \mathrm{~mm}$ and naked axes 1 $2 \mathrm{~mm}$ below them. Pseudoparaphyllia lanceolate. Axillary hairs 2-3-celled, ca. $170 \mu \mathrm{m}$ long, apical cell $65 \times 7.5 \mu \mathrm{m}$. Leaves straight, $0.9-1.5 \times 0.2-0.4 \mathrm{~mm}$, lanceolate, acuminate, entire to indistinctly serrulate

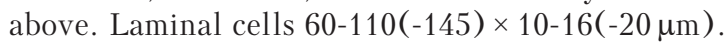
Alar cells wider and shorter, in wide group across the leaf base. Dioicous. Sporophytes unknown in this subspecies.

Lazarenko (1946) described Cephalocladium zerovii from Altai as a new species and a new monotypic genus. Bardunov (1974) found it \pm widespread in South Siberia, eastward to Baikal Lake. Abramova \& Abramov (1981) found this species in Mongolia and demon- 

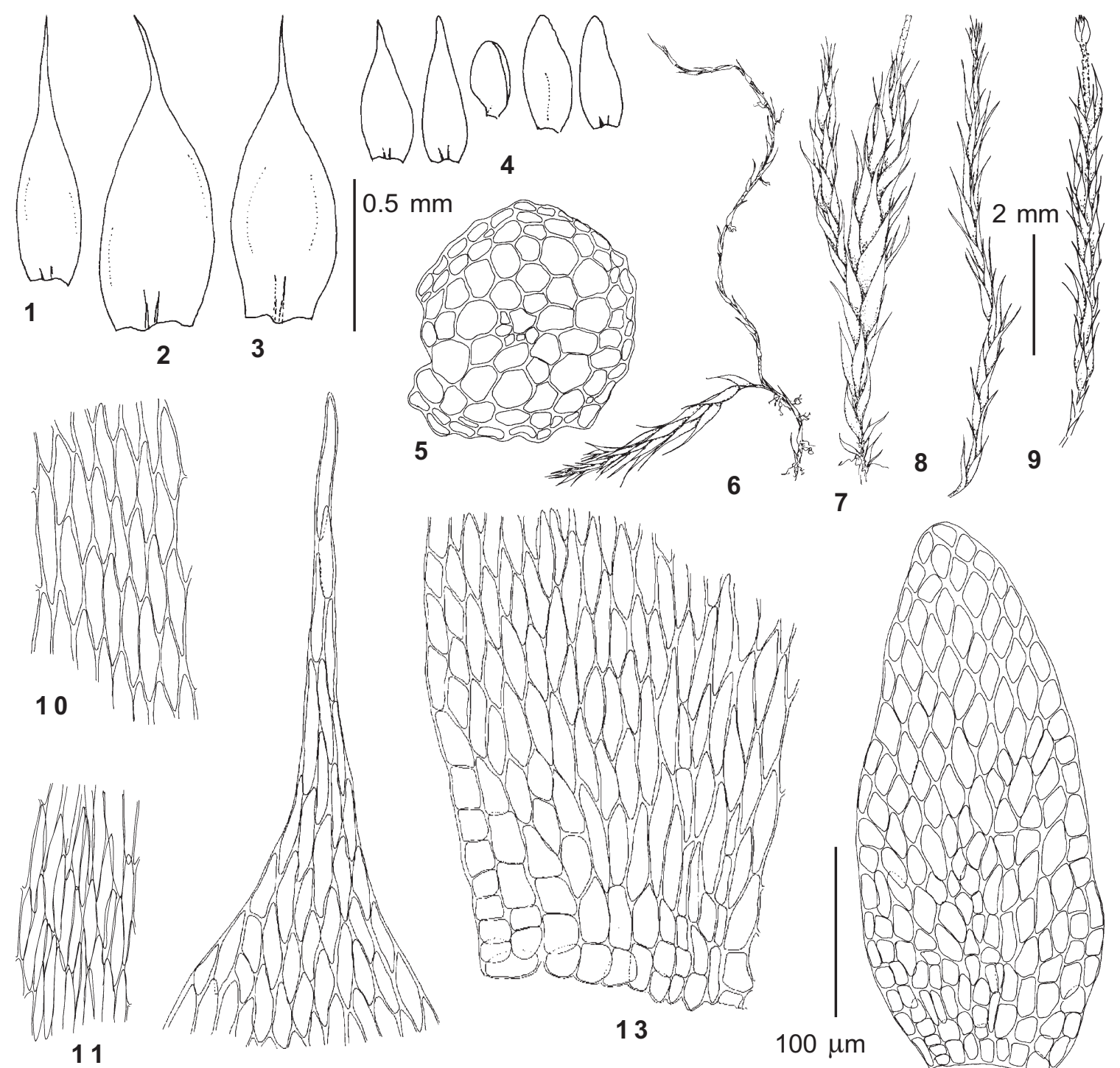

11

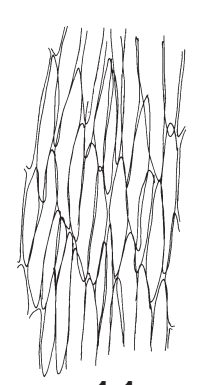

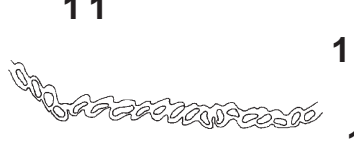

\section{5}

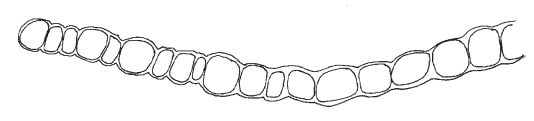

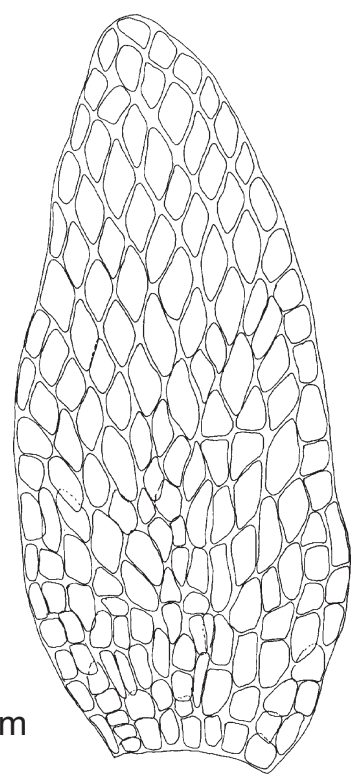

14

Fig. 69. 1-10, 12-14, 16 - Struckia argentata ssp. zerovii (Lazarenko) Tan, Buck et Ignatov (from Yailyu $450 \mathrm{~m}$ Ignatov 0/1185) and 11, 15 S. argentata C. Müll. ssp. argentata (from Buthan, Griffith LE): 1-3 - stem leaves; 4,14 - caducous leaves; 5 - stem cross-section; 6-9 - habit; 10, 11 - middle laminal cells of stem leaf; 12 - upper laminal cells of stem leaf; 13 - alar cells of stem leaf; 15, 16 - leaf cross-section. Scale bars: $2 \mathrm{~mm}-$ for 6-9; $0.5 \mathrm{~mm}-$ for 1 4; $100 \mu \mathrm{m}-$ for $5,10-16$.

strated that Siberian and Mongolian plants are the same as Fabronia enerve Broth. described from Sichuan. Tan \& al. (1990) compared Cephalocladium zerovii and Fabronia enerve with Struckia argentata, a monotypic genus known from Himalayas and Yunnan, and found them conspecific. However they found that southern population of $S$. argentata dif- fers from the northern by (1) tumid appearance; (2) distinctly serrate leaves; (3) longer cells; (4) frequent sporophytes production; and (5) absence of caducous leaves. These differences were evaluated as subspecific because in the easternmost locality of the southern population in Sichuan intermediate plants was found (Fabronia enerve). 
Subsequent new collections from Sichuan (Koponen 46069, 45584, $46469 \mathrm{H!)}$ also represent plants with a fairly long naked subterminal zone and nearly entire leaves, exactly identical with the Altaian. Also more collections from Altai revealed that the cell length is too variable to be an useful character. Also, one peculiarity of the Himalayan plants was neglected - laminal cell ends often overlap each other, resulting in unclear cell outlines in front view, and specifically a roughened lamina surface seen in cross section (Fig. 000). We leave here the taxonomy of Struckia unchanged, since it will be discussed in a separate paper.

Distribution: Struckia argentata ssp. zerovii is rather widespread at lower elevation on mountains of South Siberia, from Altai to Baikal area, Northern Mongolia and Sichuan. In Altai it grows usually on rock outcrops, rarely on trunks, in the forest zone, but once collected in the subalpine zone.

Specimens examined: Chemal Creek, $3 \mathrm{~km}$ upstream $450 \mathrm{~m}$ (34/49); Chiri Creek, $0.5 \mathrm{~km}$ upstream $450 \mathrm{~m}$ (17/9); Chulcha River, in middle course $960 \mathrm{~m}$ (9/142), $1000 \mathrm{~m}(9 / 29), 1100 \mathrm{~m}(9 / 41 ; 9 / 50)$; Elekmonar Creek, $5 \mathrm{~km}$ upstream $700 \mathrm{~m}(26 / 27)$; Kairu Creek, 8 km upstream $1000 \mathrm{~m}(15 / 66) ;$ Oligash (between Katun and Sema) m (Zerov 16.VIII.1940 LB!); Yailyu $440 \mathrm{~m}$ (0/ 1190; $0 / 637), 445 \mathrm{~m}(0 / 1186), 450 \mathrm{~m}(0 / 1185 ; 0 / 1187$; $1 / 13 ; 1 / 5 ; 1 / 6), 460 \mathrm{~m}(0 / 1188 ; 0 / 1189), 580 \mathrm{~m}(0 /$ 1184); Yakhansoru Lake $1850 \mathrm{~m}$ (Zolotukhin 28.VI.1990); Yurga $450 \mathrm{~m}(21 / 43)$.

Hylocomiaceae (Broth.) Fleisch.

The contents of this family was discussed by Rohrer (1985a,b). He concluded that though there is no one character to delimit Hylocomiaceae from Hypnaceae, the former probably comprises a natural segregate. The apomorphic characters of Hylocomiaceae shared by only some of its representatives are as follows: (1) many species robust, forming a carpet in boreal forests or subalpine communities; (2) in Pleurozium and Rhytidiadelphus stems often ascending to erect in dense growth; in loose growth forms numerous sympodial branches are developed, which are always numerous in Hylocomium and Hylocomiastrum; (3) in all four genera rhizoids mostly on branch tips, rare or lacking on the stem; (4) Hylocomium and Hylocomiastrum have paraphyllia; (5) in Hylocomiastrum, Hylocomium and Rhytidiadelphus leaves are coarsely serrate; (6) in Hylocomiastrum umbratum and Rhytidiadelphus triquetrus costa is long and double; (7) in Hylocomium and Rhytidiadelphus triquetrus laminal cells are often prorate; (8) Pleurozium schreberi, Hylocomium splendens and Rhytidiadelphus triquetrus have reticulate ornamentation in the lower exostome teeth; (9) Pleurozium, Hylocomium and Rhytidiadelphus have endostome segments broadly perforate.

Hedenäs (1989) mentioned for Hylocomiaceae rhizoids on the stem just below the leaf insertion and on branch tips in axillary position. We have seen rhizoids on the stem below leaves only in both Altaian species of Hylocomiastrum. In Rhytidiadelphus squarrosus they were found only around branch initials. In $R$. triquetrum, Pleurozium and Hylocomium no rhizoids on the stem were observed. On branch tips rhizoids are \pm clearly axillary or in \pm indefinite position in between leaves.

\section{Hylocomiastrum Fleisch.}

This genus is sometimes not segragated from Hylocomium, since both genera have abundant paraphyllia and robust plants forming extensive mats. Rohrer (1985b) summarized the differences between Hylocomiastrum and Hylocomium as follows: (1) branching pattern variable vs.regularly bi pinnate and sympodial; (2) paraphyllia of rain-deer type vs. deer-horn type; (3) leaves strongly plicate; (4) costa stronger; (5) operculum conic vs. rostrate; (6) exostome striolate below vs. reticulate; (7) segments narrowly perforate.

Hylocomiastrum includes 3 species, 2 of which has wide circum-holarctic distribution, and H. himalayanum (Mitt.) Broth. is a mountainous East Asian species.

\section{KEY TO THE Altaian SPECIES OF HYLOCOMIASTRUM:}

1. Plants 1(-2)-pinnate, glossy, pale; leaves nondecurrent; costa single ... H. pyrenaicum 1. Plants (1-)2-3-pinnate, dull, dark-green; leaves decurrent; costa double

....................... H. umbratum

Hylocomiastrum pyrenaicum (Spruce) Fleisch. in Broth., Nat. Pflanzenfam., ed. 2, 11: 487. 1925. - Hypnum pyrenaicum Spruce, Musci Pyren. 4. 1847. - Hylocomium pyrenaicum (Spruce) Lindb., Musci Scand.: 37. $1879 . \quad$ Fig. 70

Plants robust, in pale-green, somewhat glossy mats. Stem arcuate, regularly pinnate, $7 \mathrm{~cm}$ long; epidermal cells thick-walled, central strand weak. 

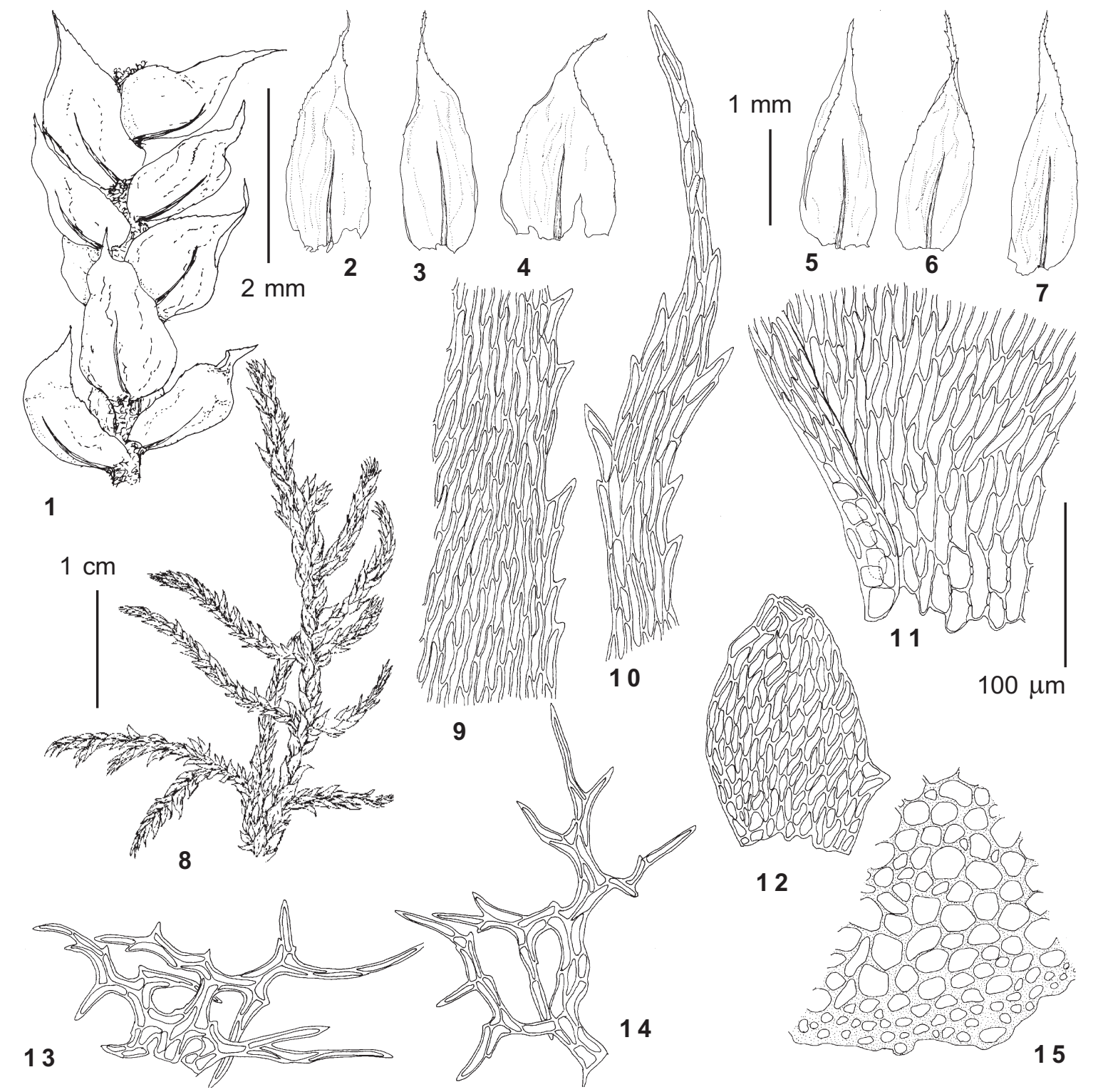

Fig. 70. Hylocomiastrum pyrenaicum (Spruce) Fleisch. (from Karakol Lakes $1900 \mathrm{~m}$ Ignatov 28/87): 1 - stem portion; 2-4 - stem leaves; 5-7 - branch leaves; 8 - habit; 9 - middle laminal cells of stem leaf; 10 - upper lamina cells of stem leaf; 11 - alar cells of stem leaf; 12 - proximal branch leaf; 13-14 - paraphyllia; 15 - stem cross-section. Scale bars: $1 \mathrm{~cm}$ - for $8 ; 2 \mathrm{~mm}$ - for $1 ; 1 \mathrm{~mm}$ - for $2-7 ; 100 \mu \mathrm{m}$ - for $9-15$.

Paraphyllia abundant on stem and branches, devided mostly to 2-3 branches from the base, but paraphyllia around branch primordia longer, irregularly pinnate to bi pinnate branching. Pseudoparaphyllia transversely ovate at base of branch primordia. Axillary hairs 4-5-celled, 100-150 $\mu \mathrm{m}$ long; apical cell $50 \times 11 \mu \mathrm{m}$. Stem leaves erect, 1.8-2.2 ×0.8-1.0 $\mathrm{mm}$, broadly ovate, acuminate, rounded at base, nondecurrent, plicate; costa single, up to $3 / 4$ the leaf length; margins recurved at base, coarsely serrate above, subentire below. Laminal cells 30-55 × 5-6.5
(4-4.5/1.5-2) $\mu \mathrm{m}$. Cells in leaf corners not differentiated.

Dioicous. No sporophytes found in Russian Altai, but old setae were seen in one collection from Kazakh Altai (Leninogorsk Distr., 1300 m, Voroschilov 3608, MHA). Perichaetial leaves $1.6 \times 0.8$ $\mathrm{mm}$, clasping the base of seta, with reflexed apex, ecostate, smooth.

Distribution: The species is common in mountainous areas throughout northern parts of the Holarctic, growing in boreal and alpine types of vegeta- 


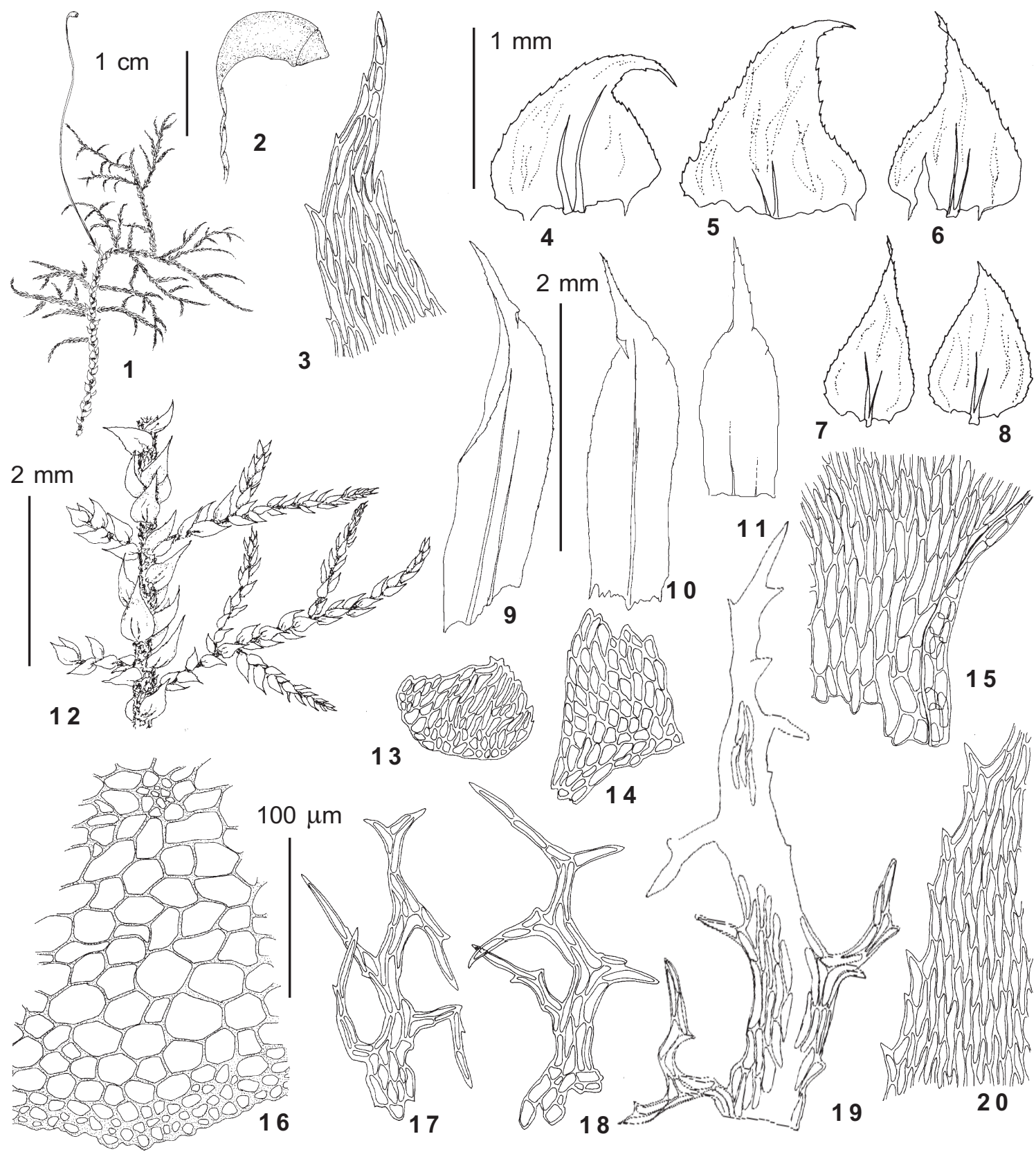

Fig. 71. Hylocomiastrum umbratum (Hedw.) Fleisch. (from Uedinennoye Lake $880 \mathrm{~m}$ Ignatov 0/604): 1 - habit; 2 - capsule; 3 - upper laminal cells of stem leaf; 4-6 - stem leaves; 7-8 - branch leaves; 9-10 - outer perichaetial leaves; 11 - inner perichaetial leaf; 12 - portion of stem with branches; 13-14 - pseudoparaphyllia; 15 - alar cells of stem leaf; 16 - stem cross-section; 17-18 - paraphyllia; 19 - paraphyllium of close proximity to branch primordia; 20 - middle laminal cells of stem leaf. Scale bars: $1 \mathrm{~cm}$ - for $1 ; 2 \mathrm{~mm}$ - for 2,$12 ; 1 \mathrm{~mm}$ - for 4-9; $0.5 \mathrm{~mm}-$ for 10 $11 ; 100 \mu \mathrm{m}-$ for $3,13-20$.

tion. In Altai Hylocomiastrum pyrenaicum occurs mostly in the alpine and subalpine zones, on soil under shrubby and herbaceous canopy and among rocks. In the forest zone it grows sporadically on rock outcrops or on organic substrates (litter, old stumps, tree bases).
Specimens examined: Ak-Turu Creek, upper course 2500 m (Nekrasova 11.VIII.1911 LE!); Ayukol $1350 \mathrm{~m}$ (0/ 1212; 0/596); Bayas Lake $1750 \mathrm{~m}$ (0/1217), $2000 \mathrm{~m}$ (0/ 1213; 0/597); Bolshoye Kurkure Creek, upper course 2300 m (Galanin 9.VIII.1976); Kairu-Bazhi Peak 2150 m (13/ 18); Kaitanak Creek 1500 m (A. Krylov \& Rechan 10.VII.1968 LE!); Karakol Lakes 1900 m (28/132; 28/ 

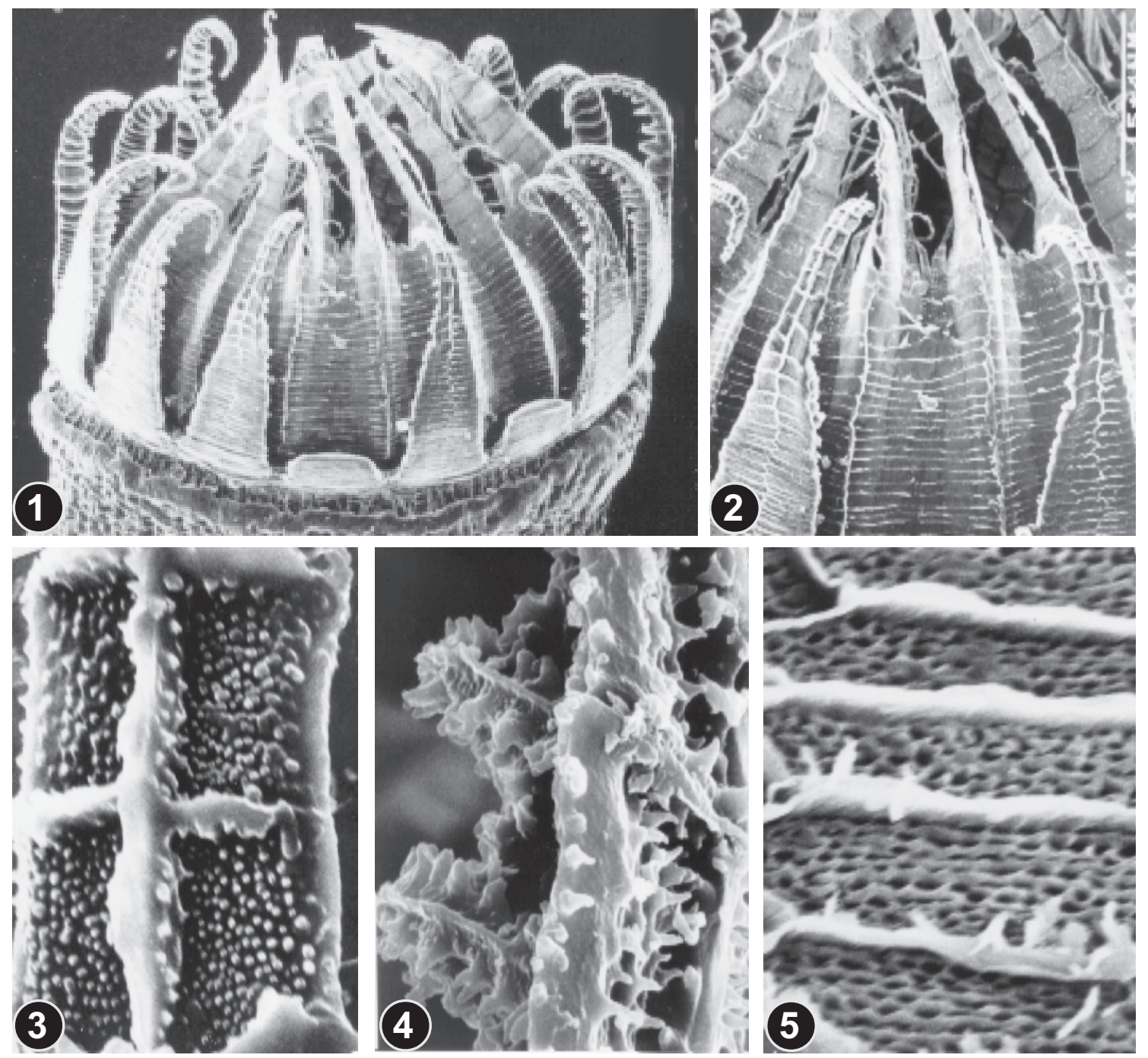

Fig. 72. Hylocomiastrum umbratum (Hedw.) Fleisch. (from Uedinennoye Lake $880 \mathrm{~m}$ Ignatov 0/604): 1-2 peristome ( $1-1504 ; 2-225 \times) ; 3$ - outer surface of exostome tooth in upper part $(2250 \times)$; 4 - side view of exostome tooth in upper part, showing incrassate and warty papillose inner trabeculae $(4000 \times)$; 5 - outer surface of exostome tooth in lower part $(4000 \times)$.

162; 28/62; $28 / 87) ;$ Kayakkatuyarykskij Creek $2150 \mathrm{~m}$ (7/18); Kobiguayuk Creek $2400 \mathrm{~m}(0 / 599 ; 0 / 600)$; Sarulu Creek, upper course (Nikitina 30.VI.1925 LE!); Srednij Shaltan Creek $600 \mathrm{~m}(0 / 1216), 620 \mathrm{~m}(0 / 1218)$, $670 \mathrm{~m}(0 / 1214)$; Tabozhok Peak $2600 \mathrm{~m}(31 / 41)$; Toshkalykaya Peak 2500 m (Zolotukhin 14.VII.1990); Uedinennoye Lake $880 \mathrm{~m}(0 / 1215)$.

Hylocomiastrum umbratum (Hedw.) Fleisch. in Broth., Nat. Pflanzenfam., ed. 2, 11: 487. 1925. - Hypnum umbratum Hedw., Sp. Musc. Frond. 263. t. 67 f. 10-13. 1801. - Hylocomium umbratum (Hedw.) B. S. G., Bryol. Eur. 5: 175. 1852.

Figs. $71 \& 72$

Plants robust, in dull dark-green loose mats. Stem to $10 \mathrm{~cm}$ long,once,bi- or tri pinnate-branched , \pm ar- cuate, with thick-walled epidermal cells and weak central strand. Paraphyllia densely covering the stem and branches, strongly branched from the base, but paraphyllia around branch primordia longer, pinnate-branching to serrate-ciliate. Pseudoparaphyllia transversely ovate. Axillary hairs 3-4-celled, ca. 150 $\mu \mathrm{m}$ long, apical cell ca. $60 \times 10 \mu \mathrm{m}$. Stem leaves loosely erect, $1.5-1.8 \times 1.0 \mathrm{~mm}$, broadly ovate-triangular, shortly acuminate, narrowly decurrent; costa double, reaching $1 / 3-2 / 3$ of the leaf length; margins coarsely serrate. Branch leaves smaller, ovate-lanceolate. Laminal cells 30-60 × 4.5-7 (3-5/1.5-3) $\mu \mathrm{m}$, \pm smooth. Cells in basal corners not differentiated.

Dioicous. Sporophytes rather rare. Outer perichaetial leaves $3.2 \times 1.0 \mathrm{~mm}$, smooth, with costa double 

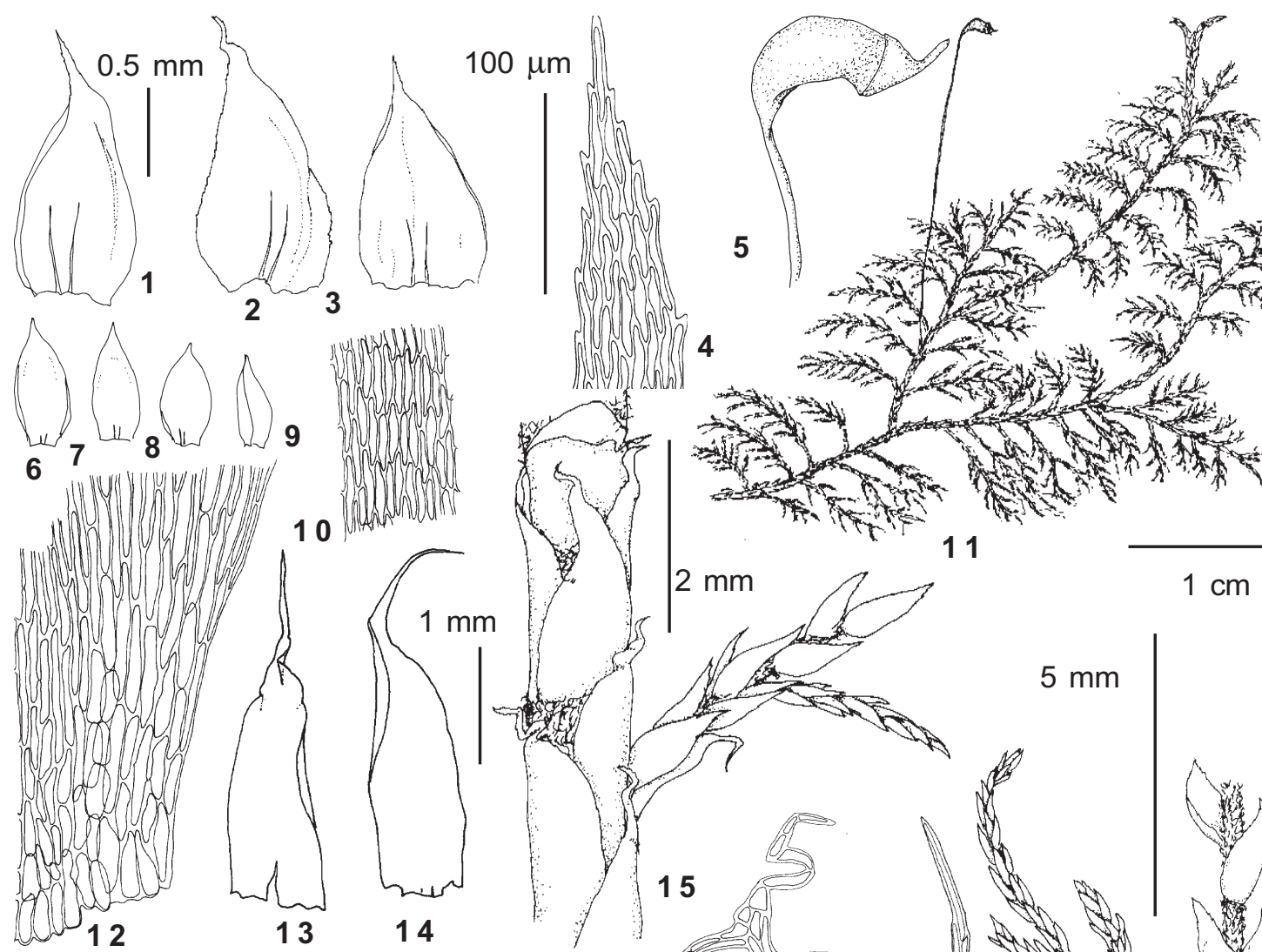

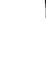
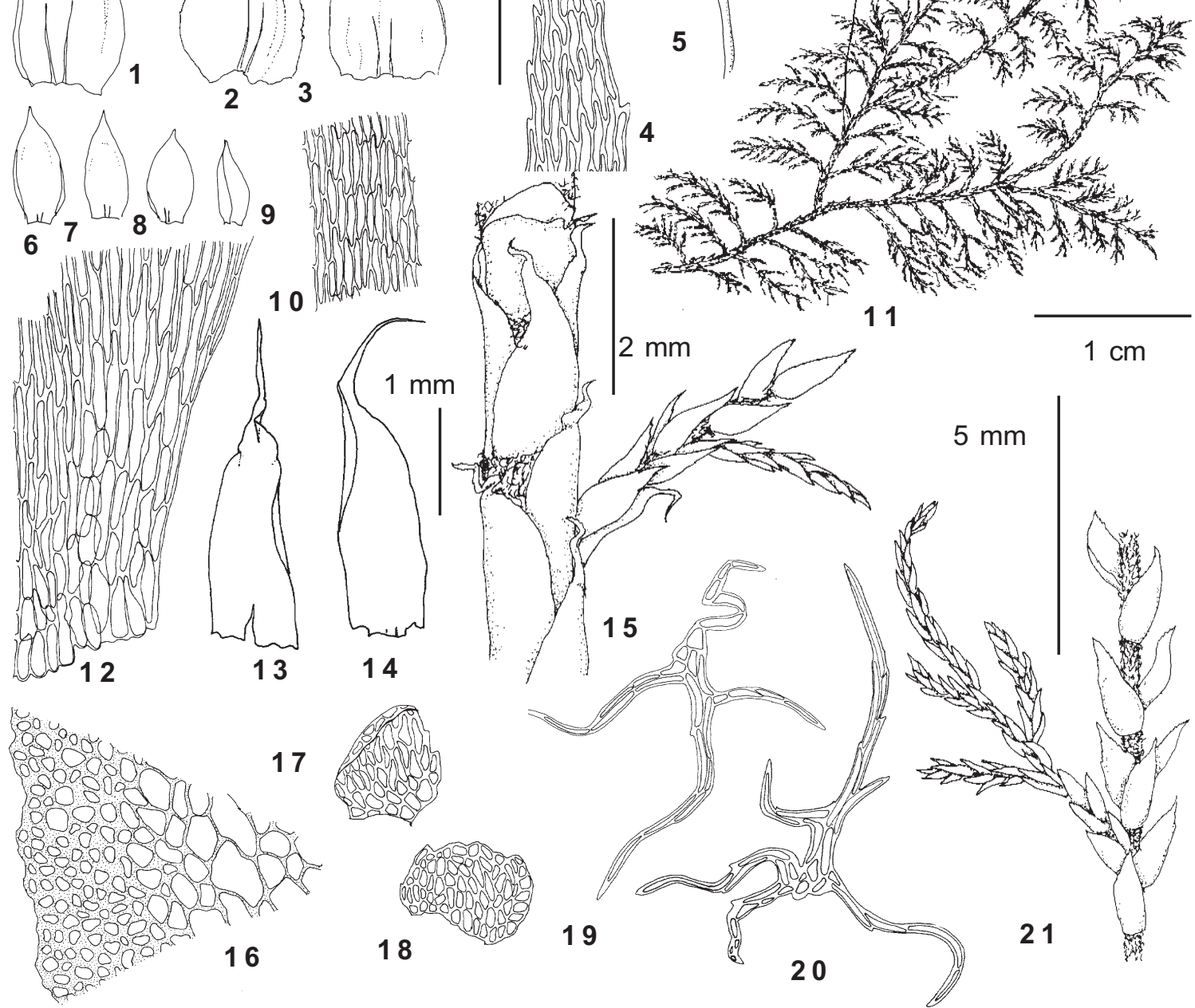

19

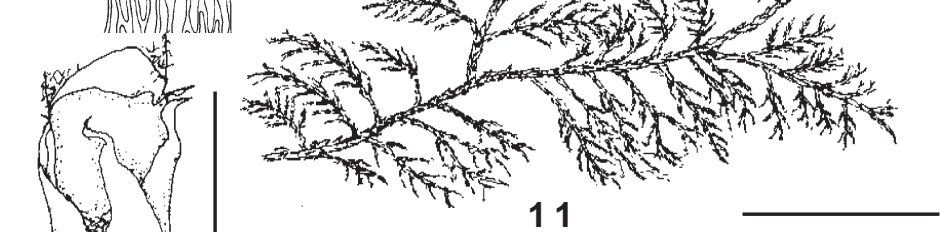

$1 \mathrm{~cm}$

Fig. 73. Hylocomium splendens (Hedw.) B.S.G. (from Bolshoye Istyube Creek $500 \mathrm{~m}$ Zolotukhin 19.V.1977): 1-3 stem leaves; 4 - upper lamina cells of stem leaf; 5 - capsule; 6-9 - branch leaves; 10 - middle lamina cells of stem leaf; 11- habit; -12 - alar cells of stem leaf; 13-14 perichaetial leaves; 15 - stem portion; 16 - stem cross-section; 17 18 - proximal branch leaves; 19-20 - paraphyllia; 21 - stem portion with branches. Scale bars: $1 \mathrm{~cm}-$ for $11 ; 5 \mathrm{~mm}$ - for 5,$21 ; 2 \mathrm{~mm}$ - for $15 ; 1 \mathrm{~mm}$ - for $13-14 ; 0.5 \mathrm{~mm}$ - for 1-3, 6-9;100 $\mu \mathrm{m}$ - for 4, 10, 12, 16-20.

or single, sometimes forked, to $2 / 3$ the leaf length, serrate above; inner perichaetial leaves shorter, reflexed, with weak double costa. Seta $3 \mathrm{~cm}$. Capsule ca. $2.5 \mathrm{~mm}$ long. Operculum conic. Exostome teeth 0.60 $\mathrm{mm}$ long, abruptly tapered in the transition zone, subentire above; perfectly reticulate below; in the transition zone densely papillose (few plates); in the upper part moderately low-papillose; dorsal trabeculae rather high; margin not especially incrassate, slightly papillose; ventral trabeculae strongly incrassate and papillose. Endostome as long as the teeth, basal membrane ca. $0.3 \mathrm{~mm}$ high; segments widely perforate; cilia nodose, sometimes appendiculate. Spores $14 \mu \mathrm{m}$.

Distribution: Hylocomiastrum umbratum has a scattered distribution in oceanic and mountain areas of the Holarctic, with few scattered localities in southern parts of the boreal zone on lowlands. In Altai it was found few times in deep canyons or in wet fir forests, at lower elevations.

Specimens examined: Bolshoye Istyube Creek $470 \mathrm{~m}$ (18/108); Kamga Creek, upper course 850 m (Martynenko 9.VIII.1935 LE!); Uedinennoye Lake 880 m (0/1210; $0 / 604), 1030 \mathrm{~m}(0 / 1211)$. 

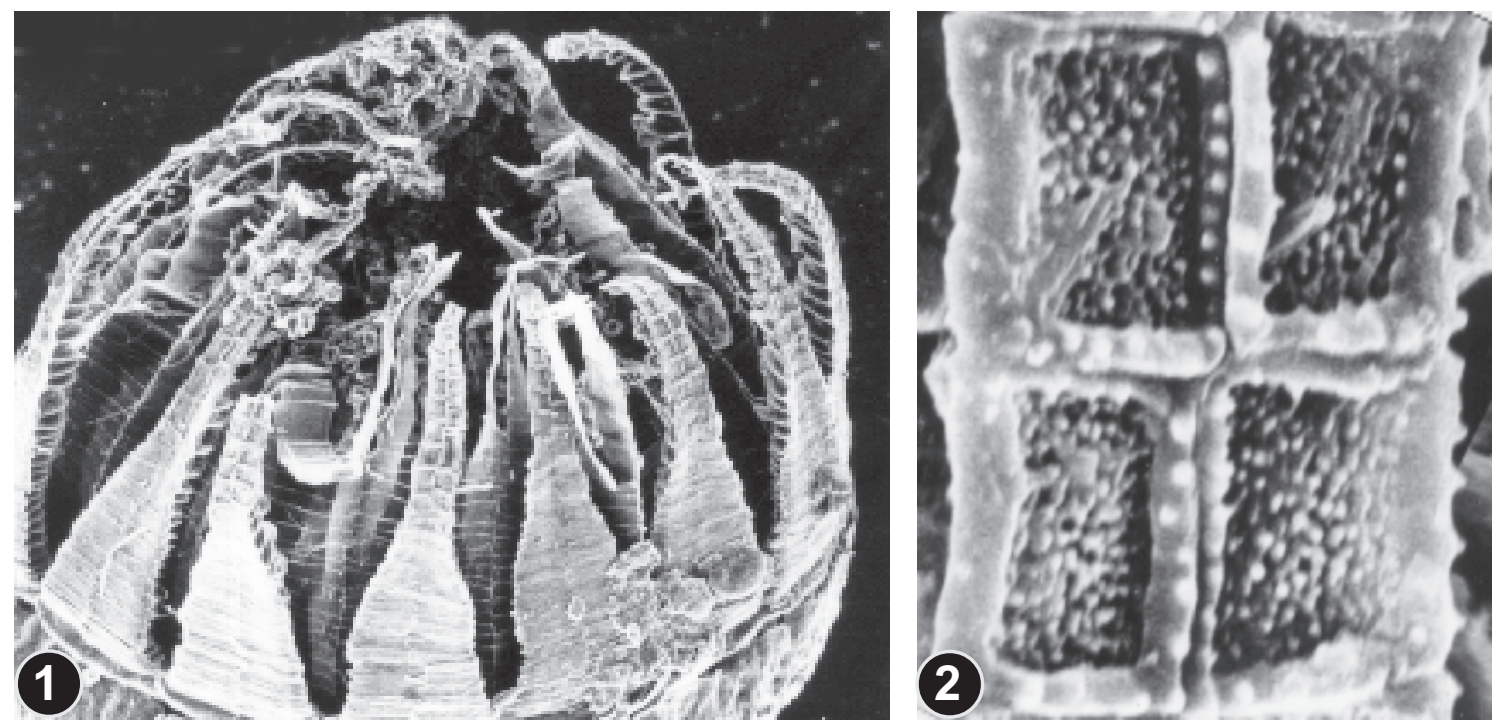

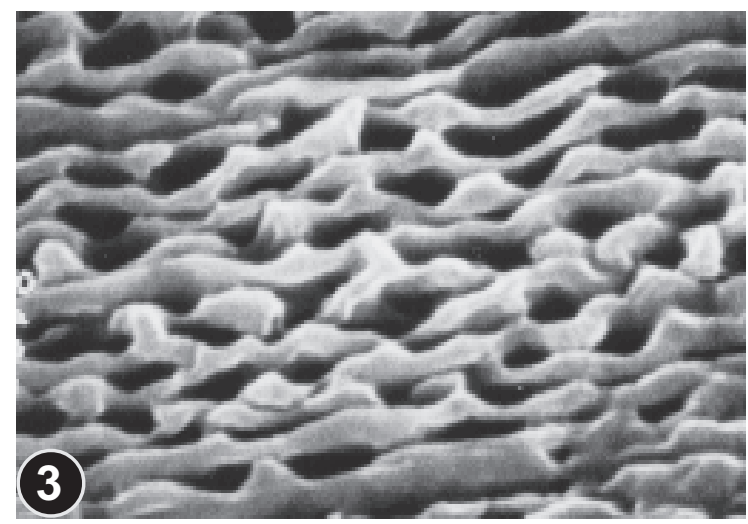

Hylocomium B. S. G.

The genus includes one species widely distributed in cool climates.

Hylocomium splendens (Hedw.) B.S.G., Bryol. Eur. 5: 173. 1852. - Hypmum splendens Hedw., Sp. Musc. 262.t. 67., f. 7-9. $1801 . \quad$ Figs. 73 \& 74

Plants robust, pale-green to brownish-green. Stem to $15 \mathrm{~cm}$ long, with weak central strand, monopodially bipinnate-branched and also regularly sympodially branched, resulting in step-wise appearance. Paraphyllia densely covering stems and branches. Pseudoparaphyllia broadly to transversely ovate. Axillary hairs 35-celled; ca. $100 \mu \mathrm{m}$ long, apical cell $40 \times 10 \mu \mathrm{m}$. Stem (i. e., main sympodial branch) leaves tightly clasping stem at base, \pm flexuose above, ca. $2.0-2.5 \times 1 \mathrm{~mm}$, ovatetriangular, abruptly narrowed to flexuose-rugose acumen, slightly plicate; costa double or single, to $1 / 3(-$ $1 / 2)$ the leaf length, margins serrate. Branch leaves smaller, oblong-lanceolate. Laminal cells 30-60×5 (3/ 2) $\mu \mathrm{m}$, thick-walled, prorate. Cells in leaf corners not differentiated, across the base orange-colored.

Dioicous. Sporophytes rather rare. Perichaetial leaves
Fig. 74. Hylocomium splendens (Hedw.) B.S.G. (from Bolshoye Istyube Creek $500 \mathrm{~m}$ Zolotukhin 19.V.1977): 1 - peristome (200×); 2 - outer surface of exostome tooth in upper part $(3000 \times)$; 3 - outer surface of exostome tooth in lower part $(1100 \times)$.

to $3.5 \times 1.0$, erect, ecostate. Seta 2-3 cm. Capsule 2.0-2.5 $\mathrm{mm}$ long. Operculum obliquely rostrate. Exostome teeth $0.6 \mathrm{~mm}$ long; abruptly tapered in the transition zone, subentire above; in the lower part imperfectly reticulate (transverse cristae wavy and anastomozed); in the transition zone densely papillose on few plates; in ther upper part moderately low papillose, with rare low papillae on relatively low dorsal trabeculae; margin incrassate, slightly papillose; ventral trabeculae smooth. Endostome about $0.55 \mathrm{~mm}$ long, basal membrane 0.2 $\mathrm{mm}$ high; segments broad and widely perforate; cilia nodose. Spores about $15 \mu \mathrm{m}$.

In Altai Hylocomium splendens is not especially polymorphous, except one form found in abundance in shrubby hummocks in a flood valley in the upper taiga zone, where plants have erect growth, less developed secondary branches and totally lacking sympodial branching. These characters fit the common Arctic var. $o b$ tusifolium (Geh.) Par. (=H. alaskanum Lesq. et James) Aust. However it is not apparent whether this population was derived from nonAltaian source or originated by means of a parallel mutation in Altaian plants.

Distribution: Very common in the Arctic and boreal regions of the Holarctic and also in conifer forests in more southern mountains, including Central and South America, Africa and New Zealand. In Altai it is very common, being absent only in very xeric regions. 

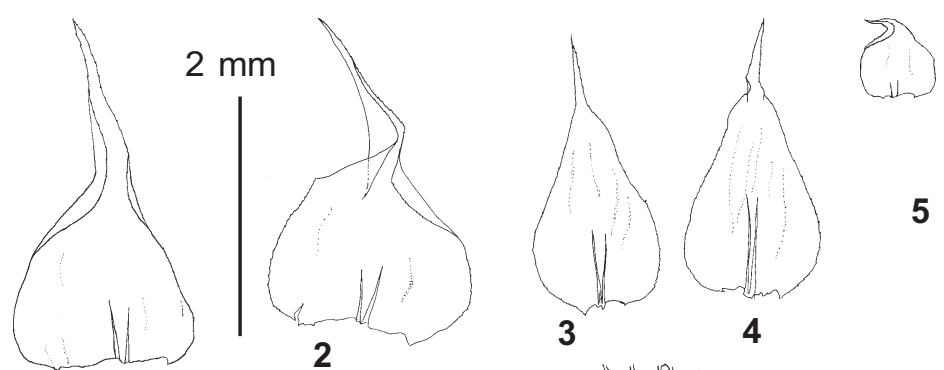

1
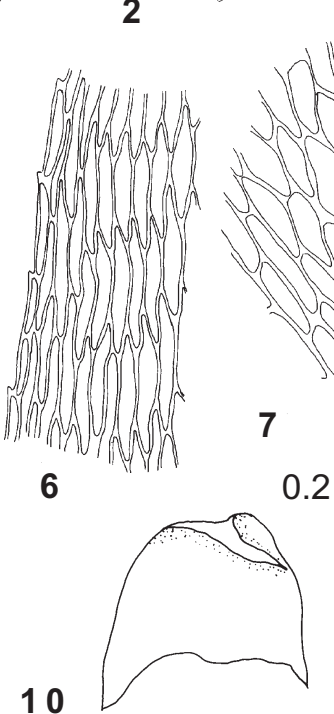

3

4

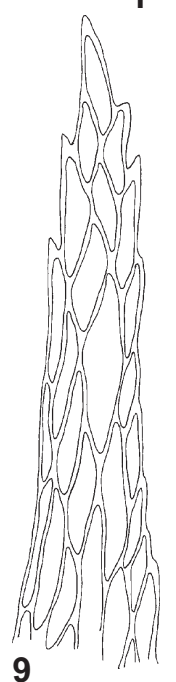

10
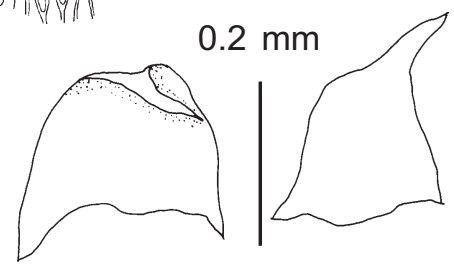

11

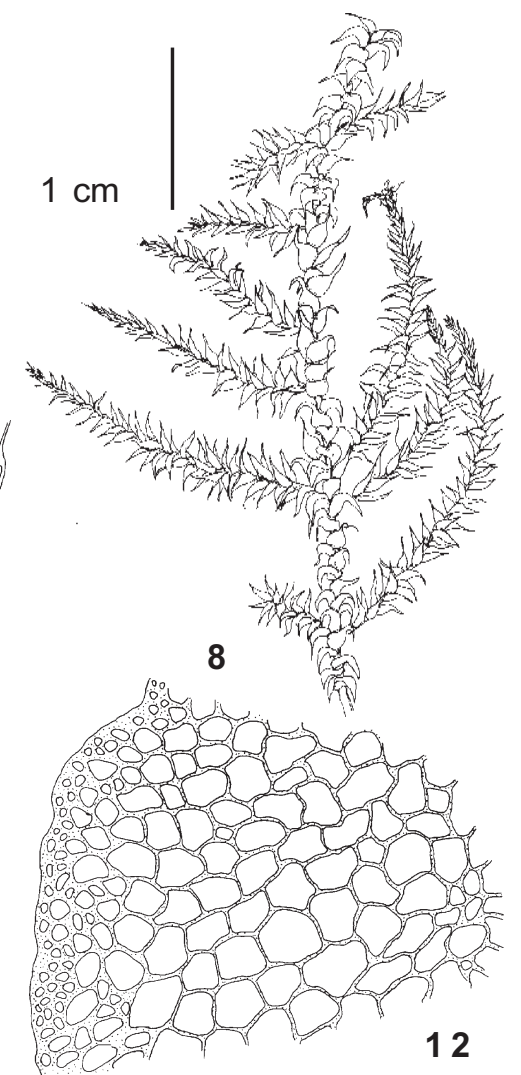

Fig. 75. Rhytidiadelphus squarrosus var. calvescens (Lindb.) Warnst. (from Yailyu $450 \mathrm{~m}$ Ignatov 0/1219): 1-2 stem leaves; 3-5 - branch leaves; 6 - middle laminal cells of stem leaf; 7 - alar cells of stem leaf; 8 - habit; 9 upper laminal cells of stem leaf; 10-11 - pseudoparaphyllia; 12 - stem cross-section. Scale bars: $1 \mathrm{~cm}-$ for 8 ; $2 \mathrm{~mm}$ - for $1-5 ; 0.2 \mathrm{~mm}$ - for $10-11 ; 100 \mu \mathrm{m}$ - for $6-7,9,12$.

Specimens examined: Ayulyuyuzyuk Creek $2100 \mathrm{~m}(0$ 173); Bayas Lake $1750 \mathrm{~m}(0 / 603)$; Bele $500 \mathrm{~m}$ (Zolotukhin 28.VII.1982); Bogoyash Creek, at mouth $2070 \mathrm{~m}$ (Zolotukhin \& al. 17.VIII.1977); Bolshoye Istyube Creek $500 \mathrm{~m}$ (Zolotukhin 19.V.1977); Chibitka Creek, at mouth 2200 m (Kuklina VII.1984); Kamga Bay 450 m (Zolotukhin 20.X.1988); Karatash $450 \mathrm{~m}$ (Zolotukhin \& al. 26.V.1984); Kishte $440 \mathrm{~m}$ (Zolotukhin 11.VII.1988); Kobiguayuk Creek 2908 m (0/601); Maloye Istyube Creek, $1 \mathrm{~km}$ upstream $600 \mathrm{~m}$ (Zolotukhin 19.V.1977); Ozernaya Creek 2150 m (Lebedeva \& al. 9.VIII.1978); Saratki Cape $440 \mathrm{~m}$ (Zolotukhin 14.X.1987); Seminskij Pass $1750 \mathrm{~m}$ (Makarov \& al. 18.VI.1972); Tokpak Creek, in middle course $2600 \mathrm{~m}$ (36/387a); Yailyu $450 \mathrm{~m}$ (0/602).

Rhytidiadelphus (Lindb. ex Limpr.) Warnst.

The genus includes 4-5 species, distributed in boreal and hemiboreal regions of the Holarctic. Main characters of the genus include: plants robust, without paraphyllia; leaves reflexed to squarrose, \pm ovate, acuminate, serrulate to serrate.

Rhytidiadelphus triquetrus differs from the rest of the species in the genus by (1) rigid straight leaves; (2) long costa; (3) prorate cells;
(4) reticulate exostome; and (5) unusually narrow axillary hairs. These seem enough for a new genus, but the conservative position seems more preferable, since the closest relatives of $R$. triquetrus are other members of the same genus.

\section{KEY TO THE Altaian SPECIES OF RHYTIDIADELPHUS}

1. Leaves gradually narrowed upward; double costa reaching about $3 / 4$ the leaf length; laminal cells strongly prorate . . R. triquetrus

1. Leaves \pm abruptly narrowed upward; double costa reaching 1/3-1/2 the leaf length; laminal cells smooth

............. R. squarrosus var. calvescens

Rhytidiadelphus squarrosus (Hedw.)

Warnst., Warnst., Krypt.-fl. Mark Brandenb. 2: 918. 1906. var. calvescens (Lindb.) Warnst., Krypt.-fl. Mark Brandenb. 2: 920. 1906. - Rhytidiadelphus subpinnatus (Lindb.) T. Kop., Hikobia 6: 19. 1971. - Hylocomium subpinnatum Lindb., Hedwigia 6: 41. 1867. Fig. 75 
Plants robust, in loose green mats. Stem ascending to somewhat arcuate above, to $12 \mathrm{~cm}$ long; with weak central strand; \pm regularly pinnate-, sometimes bi pinnate-branched. Pseudoparaphyllia broadly triangular. Axillary hairs 4-6-celled, 150-200 $\mu \mathrm{m}$ long, apical cell $50 \times 8 \mu \mathrm{m}$. Stem leaves squarrose, 2.2-2.5 $\times 1.3-1.5 \mathrm{~mm}$, ovate base appressed to erect, upper part reflexed; costa double, up to $1 / 5-1 / 4$ the leaf length; margins serrate above, serrulate below. Proximal branch leaves $2.0 \times 0.9-1.0 \mathrm{~mm}$. Median laminal cells 50-80 × 7-8 $(6-7 / 1-1.5) \mu \mathrm{m}$, smooth, near the base at margin ca. $40 \times 7-8 \mu \mathrm{m}$, between leaf corners and costa cells larger, ca. $40 \times 20 \mu \mathrm{m}$.

Dioicous. No sporophytes found in Russian Altai. SEM pictures of the striolate exostome ornamentation and of the endostome have been published by Rohrer (1985b).

The differences between typical Rhytidiadelphus squarrosus and $R$. squarrosus var. calvescens $(=R$. subpinnatus $)$ have been evaluated differently. American bryologists have consided $R$. squarrosus in a wide sense (Crum \& Anderson, 1981; Rohrer, 1985), while most European authors consider them as separate species. Important for their distinction are:

var. squarrosus: plants in dense extensive mats; stem tips straight and stellate due to strongly squarrose leaves; branches irregular and relatively short; stem leaves reflexed to squarrose, ovate at base and clasping the stem; lower branch leaves of the same shape, finely serrulate.

var. calvescens: plants in loose mats, often distally arcuate; \pm regularly pinnate-branched, branches sometimes with secondary branches; stem leaves reflexed, but not squarrose, broadest near the base, so leaves are not clasping the stem which is well visible in between leaves; lower branch leaves different from stem leaves, rather coarsely serrate.

All the specimens from Altai belong to the latter variety.

Though typical expressions of these varieties look very distinct, transitional forms occur in herbaria. Field observations in Ural Mts. and European Russia showed that in woodlands on bogging clear-cut areas and along wet trails var. calvescens (common in nearby forests) is gradually modified towards var. squarrosus, becoming sometimes indistinguishable from North-European plants. High moisture and open light are probably responsible for this change.
Some Altaian plants from open places in subalpine zone also are somewhat similar to $R$. squarrosus s. str. in habit.

It is highly probable that the var. squarrosus s. str., a weed of grasslands in North Europe, comprises a monophyletic line. Rohrer (1985) considered it to have originated in disturbed grasslands, while Koponen (1971) suggested that its original habitats were sea shore meadows. However there is virtually no way to distingush it from "squarrosus-like" expressions of var. calvescens in Chukotka, Alaska, British Columbia, mountains of South Siberia and East European lowlands. The only difference is that North-European var. squarrosus forms extensive populations, which are very constant in their characters, while in large populations from other places trends to var. calvescens are usually apparent.

Distribution: Rhytidiadelphus squarrosus var. calvescens has a Holarctic distribution confined mostly to boreal forests, penetrating in coniferous forest in mountains of Central Europe, Hokkaido and Honsu in Japan, northern parts of mountains of Middle Asia. Reported from Sichuan. In Altai it has scattered distribution in conifer forests, under tall herbs (both in the forest and subalpine belts), and in dwarf Betula shrubs in the subalpine zone.

Specimens examined: Bardaky Lake $2050 \mathrm{~m}$ (13/112); Bayas Creek, in middle course $1100 \mathrm{~m}$ (16/16); Bolshoye Istyube Creek $470 \mathrm{~m}$ (18/131); Gorno-Altaisk $400 \mathrm{~m}$ (35/ 53); Kairu Creek, 22 km upstream $1550 \mathrm{~m}$ (14/31); Kaitanak Creek 1500 m (A. Krylov \& Rechan 10.VII.1968 LE!); Oligash (between Katun and Sema) (Zerov 17.VIII.1940 LB!); Uedinennoye Lake $880 \mathrm{~m}$ (0/1220); Ust-Sema 500 m (24/14); Yailyu 450 m (0/1219), 600 m $(0 / 1221)$.

Rhytidiadelphus triquetrus ( $\mathrm{Hedw}$.) Warnst., Krypt.-Fl. Brandenburg, Laubm. 920: 996. t. 926 f. 6. 1906. - Hypnum triquetrum Hedw., Sp. Musc. Frond. 256. $1801 . \quad$ Figs. $76 \& 77$

Plants robust, in yellow-green mats. Stem ascending, to $10 \mathrm{~cm}$ long; with weak central strand; regularly pinnate-branched, leaves and young branches crowded terminally, so stem is subcomose, branches $1.7 \mathrm{~cm}$ long, attenuate at tips. Pseudoparaphyllia broadly triangular. Axillary hairs 4-6-celled, ca. 200 $\mu \mathrm{m}$ long, apical cell $45-50 \times 6 \mu \mathrm{m}$. Stem leaves \pm reflexed to wide spreading, $4.0 \times 2.1 \mathrm{~mm}$, ovate-triangular, cordate at base, gradually acute, plicate; costa double, long, 3/4-4/5 the leaf length; margins serrate. Branch leaves 2.3-2.4 $\times 0.9-1.0 \mathrm{~mm}$, of the same shape as stem leaves. Laminal cells 60-110 × 7 (3-4/ 2-3) $\mu \mathrm{m}$, strongly prorate. Alar cells subquadrate, forming small indistinct group. 

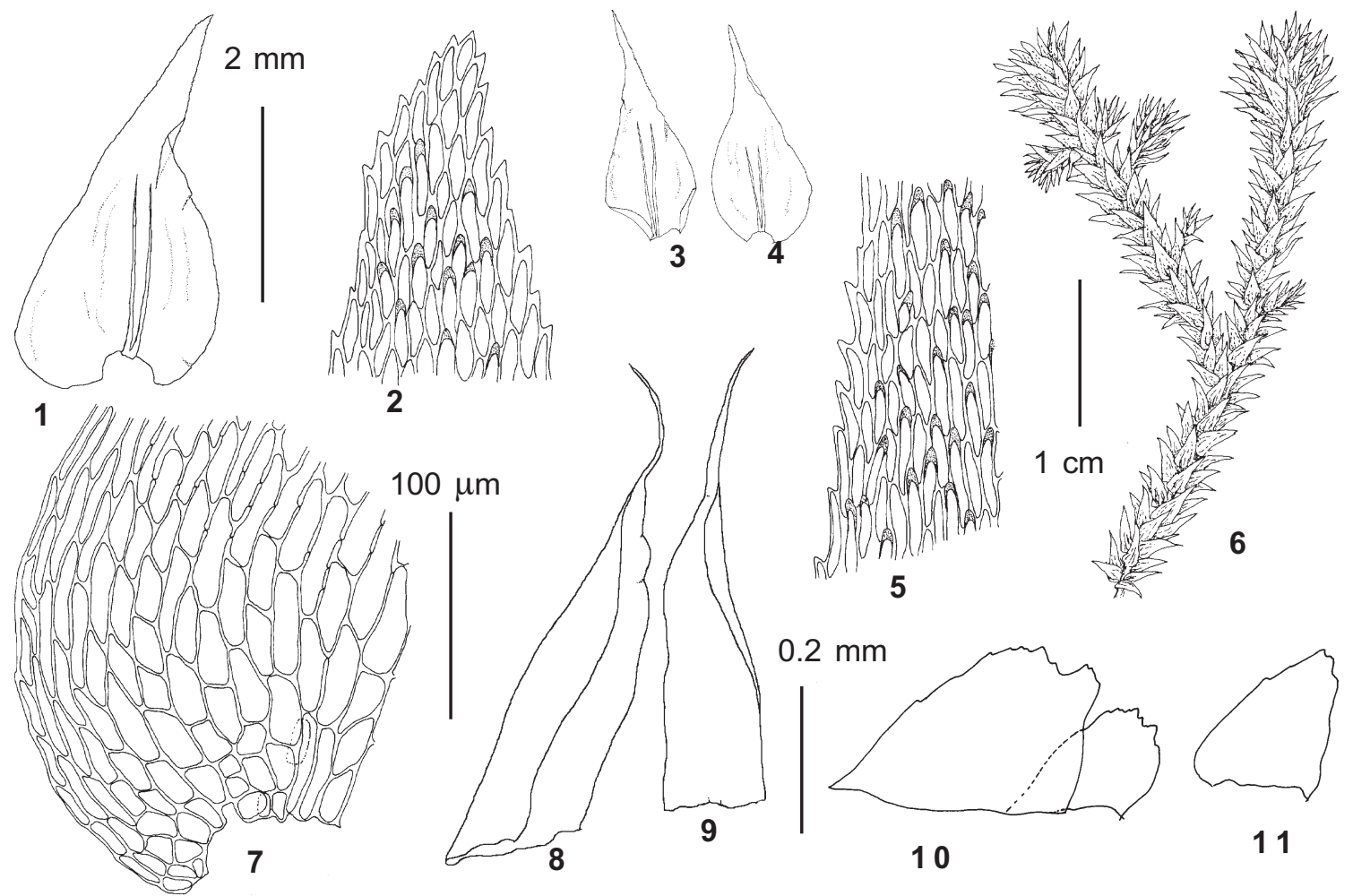

Fig. 76. Rhytidiadelphus triquetrus (Hedw.) Warnst. (from Kairu Creek, 8 km upstream 1000 m Ignatov 15/49): 1 - stem leaf; 2 - upper lamina cells of stem leaf; 3-4 - branch leaves; 5 - middle lamina cells of stem leaf; 6 - habit; 7 - alar cells of stem leaf; 8-9 - perichaetial leaves; 10-11 - pseudoparaphyllia. Scale bars: $1 \mathrm{~cm}-$ for 6 ; $2 \mathrm{~mm}-$ for $1,3-4,8-9 ; 0.2 \mathrm{~mm}$ - for $10-11 ; 100 \mu \mathrm{m}$ - for $2,5,7$.

Dioicous. Sporophytes rather rare. Perichaetial leaves 3.3-4.1 × 0.7-1.2 mm, oblong, abruptly acuminate, smooth, entire, with indistinct double costa to about $1 / 4$ the leaf length. Seta $1.5-2.0 \mathrm{~cm}$. Capsule 2.0-2.5 mm long, furrowed when open and dry. Exostome teeth $0.6 \mathrm{~mm}$ high; straight to ca. $2 / 3$, distinctly narrowed in the transition zone, entire, regularly reticulate below; in the middle abruptly grading to the upper part where smooth or longitudinally furrowed; dorsal trabeculae prominent, with incrassate margin; ventral trabeculae smooth. Endostome $0.55 \mathrm{~mm}$ long, basal membrane ca. $0.30 \mathrm{~mm}$ high; segments broadly perforate and usually strongly split; cilia nodose, sometimes eroded-flexuose. Spores 18-23 $\mu \mathrm{m}$.

Distribution: The species is common in the boreal and hemiboreal zones and at less extend in temperate regions of the Holarctic, and in Himalayas. In Altai it is common in \pm mesic forests, but never penetrates above tree-line.

Specimens examined: Adylda Creek $1100 \mathrm{~m}(34 / 140$ 34 /82); Ayulyuyuzyuk Creek 2100 m (0/383); Bardaky Lake $2050 \mathrm{~m}$ (13/113); Bolshoi Yaloman Creek, in middle course $1500 \mathrm{~m}$ (Makarov \& al. 15.VII.1972); Bolshoye Istyube Creek $470 \mathrm{~m}$ (0/2089a; 18/132); Chelyush Cape $450 \mathrm{~m}$ (Zolotukhin \& al. 19.VII.1980); Chemal Creek, 3 km upstream $450 \mathrm{~m}$ (34/25); Chemal, $5 \mathrm{~km}$ to the SE 500 m (Makarov \& al. 27.VI.1972); Kairu Creek, 8 km up stream 1000 m (15/135a; 15/49); Kairu-Bazhi Peak 2050 m (13/107a); Karagai 450 m (Zolotukhin 11.VIII.1988); Kayakkatuyarykskij Creek 1600 m (8/69); Kishte 440 m (Zolotukhin 11.VII.1988); Korbu 440 m (Zolotukhin 20.X.1988); Malyi Yaloman Creek, 8 km upstream $900 \mathrm{~m}$ (25/22); Yailyu $450 \mathrm{~m}(0 / 1204), 500 \mathrm{~m}(0 / 1203)$.

\section{Pleurozium Mitt.}

This monotypic genus has a long history of placement in various families (see a review in Rohrer, 1985a,b). The placement in Entodontaceae was suggested by Fleischer (1914, 1923) and Brotherus (1925), and was accepted in many manuals. Some authors placed it in Hypnaceae without certain relations to other groups (Nishimura \& al., 1984). Another position, close to (or within) Hylocomium and Rhytidiadelphus, was accepted by De Notaris (1867), Limpricht (18951904), Nyholm (1965) and in recent literature also by Buck (1980) and Rohrer (1985a, b). Important characters includes robust plants, forming extensive mats in conifer forests, rhizoids mostly on branch tips, reticulate exostome ornamentation, and broad perforation of endostome. 

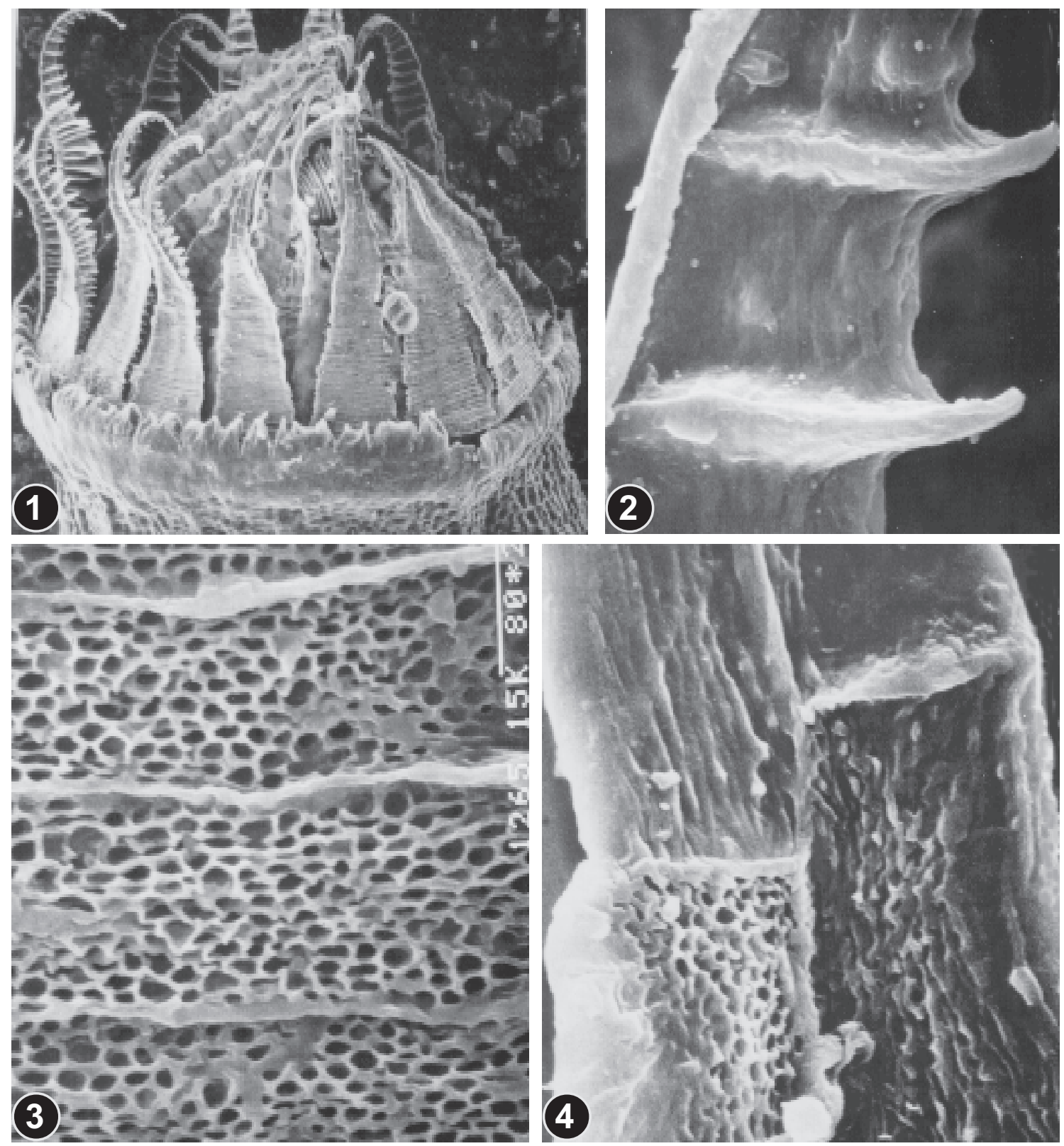

Fig. 77. Rhytidiadelphus triquetrus (Hedw.) Warnst. (from Kairu Creek $1000 \mathrm{~m}$ Ignatov 15/49): 1 - peristome $(160 \times) ; 2-$ side view of exostome tooth in upper part, showing smooth inner trabeculae $(3500 \times)$; 3 - outer surface of exostome tooth in lower part (5500×); 4 - outer surface of exostome tooth in transition zone $(4200 \times)$.

Plerozium differs from related genera by (1) lacking paraphyllia; (2) leaves obtuse and nearly entire; (3) \pm distinctly differentiated alar groups.

Pleurozium schreberi (Brid.) Mitt., J. Linn. Soc., Bot. 12: 537. 1869. - Hypnum schreberi Brid., Muscol. Recent. 2(2): 88. 1801 Figs.78 \& 79

Plants rather robust, in green to yellow-green glossy extensive mats. Stem imbricate-foliate, erectascending when growing in dense mats, cherry-red, 5-
$7 \mathrm{~cm}$ long; with weak central strand and thick-walled epidermal cells; regularly pinnate-branched, branches to $8 \mathrm{~mm}$ long, attenuate; in non-dense growth (on tops of stumps, etc.), sympodial branching common, with arcuate sympodial branches. Pseudoparaphyllia broadly triangular to transversely ovate. Axillary hairs 4-6-celled, ca. $250 \mu \mathrm{m}$ long, apical cell 40-50 $\times 11 \mu \mathrm{m}$. Stem leaves 1.8-2.6 $\times 1.0-1.4 \mathrm{~mm}$, ovate, obtuse, plicate when dry; margins incurved, entire to serrulate above. Branch leaves 0.9-1.1 $\times 0.3-0.5 \mathrm{~mm}$. Laminal 

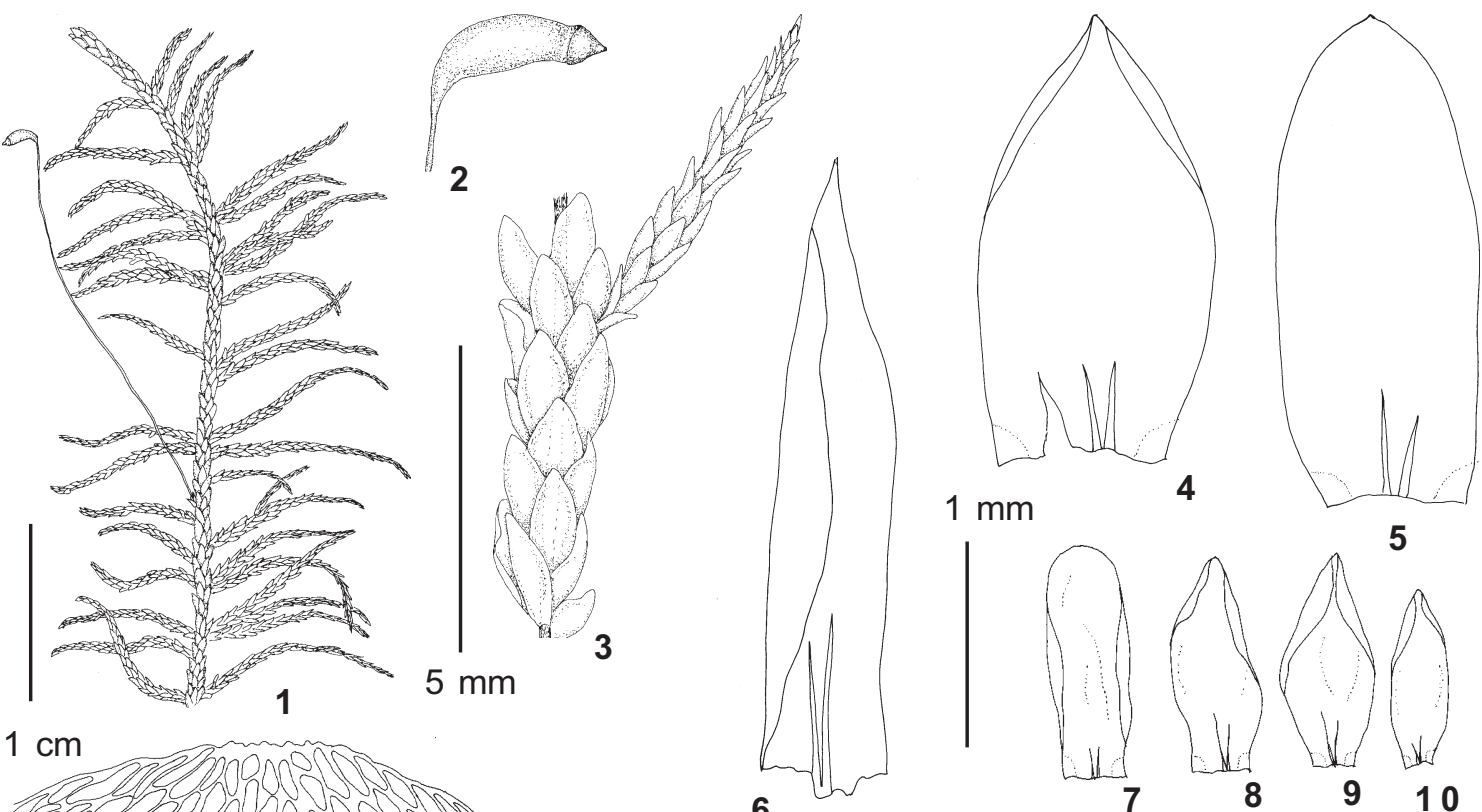

$1 \mathrm{~mm}$

5
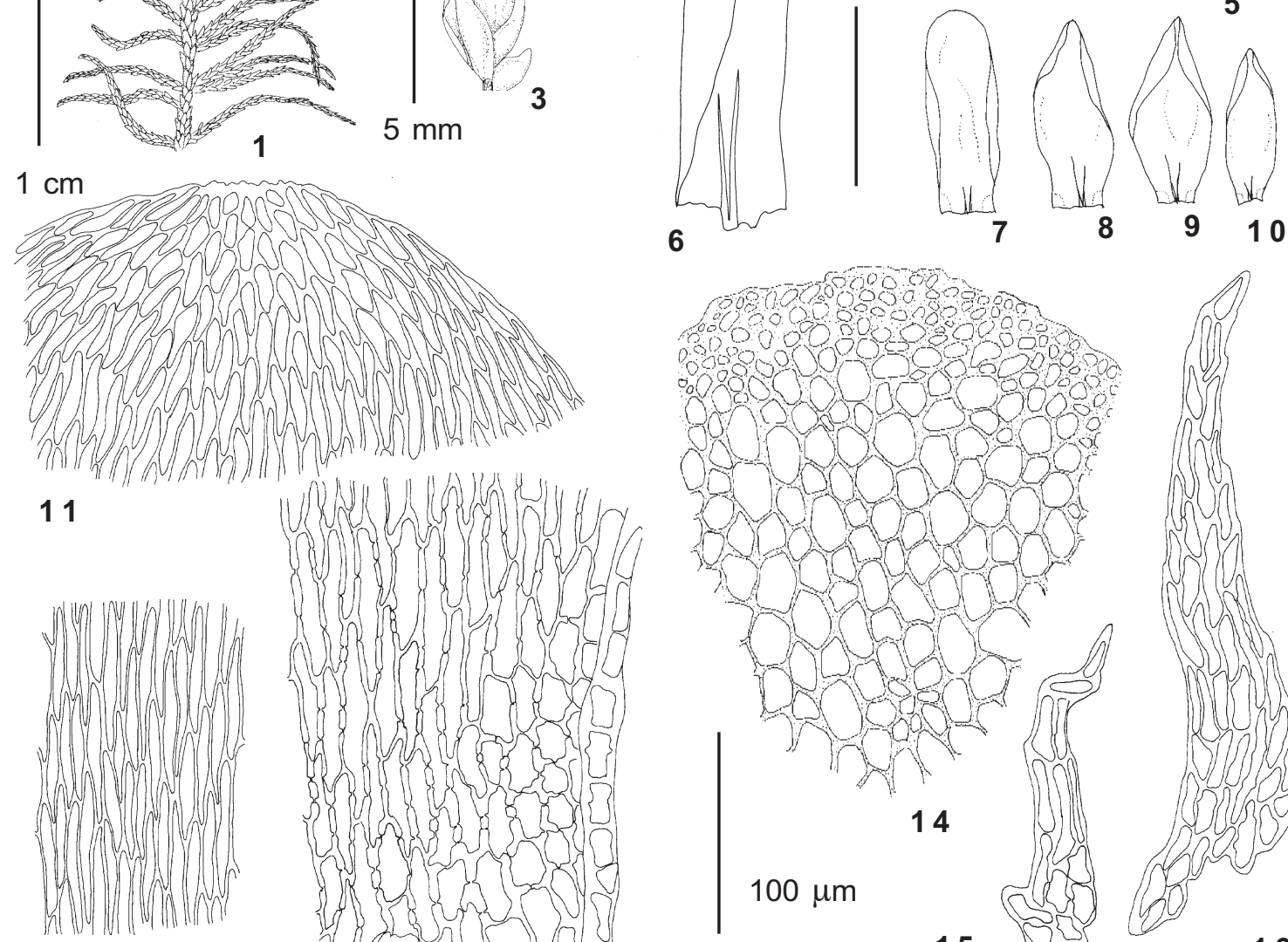

12
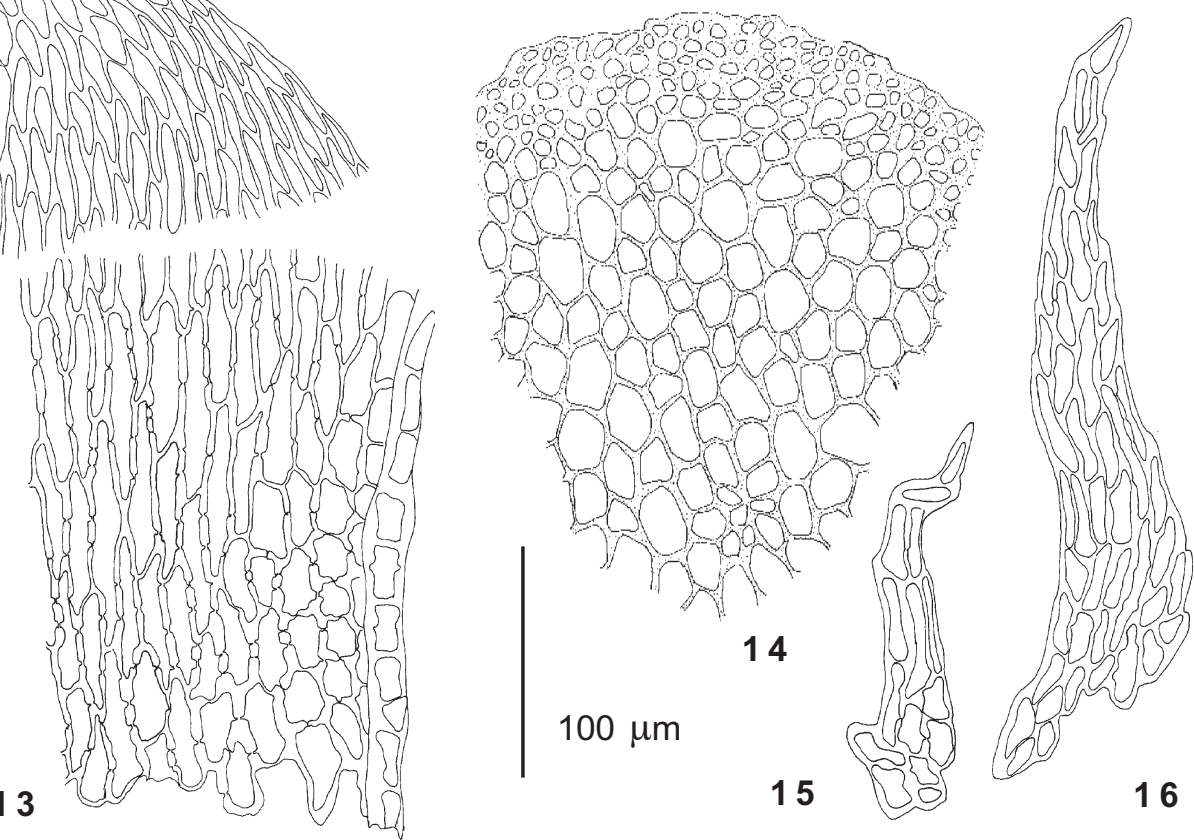

Fig. 78. Pleurozium schreberi (Brid.) Mitt. (from Uedinennoye Lake $880 \mathrm{~m}$ Ignatov 0/977): 1 - upper laminal cells of stem leaf; 2-5 - branch leaves; 6 - capsule; 7 - alar cells of stem leaf; 8 - habit; 9 , 11 - pseudoparaphyllia; 10 - portion of stem with a branch; 12 - stem cross-section; 13-15 - perichaetial leaves; 16 - middle laminal cells of stem leaf. Scale bars: $1 \mathrm{~cm}$ - for $8 ; 5 \mathrm{~mm}$ - for 6,$10 ; 1 \mathrm{~mm}$ - for $2-5 ; 100 \mu \mathrm{m}$ - for 1, 7, 9, 11, 12, 16 .

cells 50-105 × 8-10(6-7/2-4 ) $\mu \mathrm{m}$. Alar cells subquadrate, forming a well-delimited, often colored group.

Dioicous. Sporophytes rather rare. Perichaetial leaves $3.0 \times 0.7 \mathrm{~mm}$, erect, lanceolate, smooth, ecostate. Seta $3 \mathrm{~cm}$. Capsule ca. $2.5 \mathrm{~mm}$ long. Operculum conic. Annulus none. Exostome teeth 0.55-0.60 mm long, straight to ca. $2 / 3$, distinctly narrowed in the transition zone, entire; irregularly reticulate below; in the middle densely papillose on few plates; in the upper part with small low papillae arranged in indistinct longitudinal rows; dorsal trabeculae and incrassate margin low-papillose; ventral trabeculae smooth. Endostome $0.50 \mathrm{~mm}$ long, basal membrane $0.20 \mathrm{~mm}$ high; segments broadly perforate and often strongly slit; plates of the outer surface of segments jointed to the upper plates at apparent angle, 


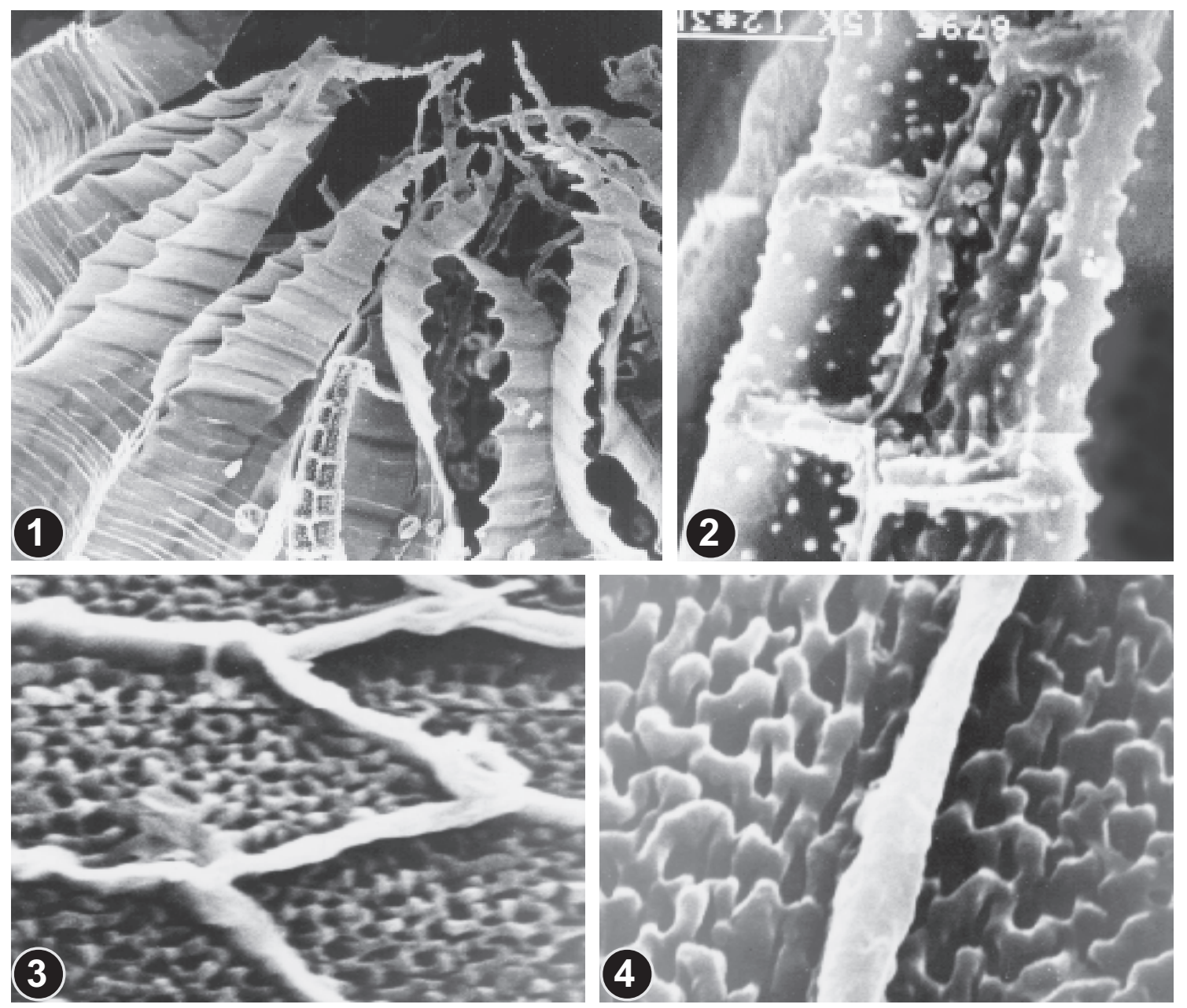

Fig. 79. Pleurozium schreberi (Brid.) Mitt. (from Uedinennoye Lake $880 \mathrm{~m}$ Ignatov 0/977): 1 - part of peristime $(400 \times)$; 2 - outer surface of exostome tooth in upper part $(3400 \times)$; 3-4 - outer surface of exostome tooth in lower part $(3-6000 \times ; 4-1100 \times)$.

resulting in peculiar transverse ridges. Cilia appendiculate. Spores 16-20 $\mu \mathrm{m}$.

An easily known species by robust julaceous plants with obtuse leaves and red stems.

Distribution: A very common moss in the Arctic, boreal and hemiboreal regions of the Holarctic, $P$. schreberi rarely occurs in temperate forests where it grows mostly as an epixylic species. Outside the Holarctic it is known in high mountains of Central and South Americas. In Altai Pleurozium schreberi occurs in nearly all the mesic forests and alpine communities (up to the uppermost elevations studied). It is amazingly absent in South-East Altai, on the south-facing slope of Kuraiskij Mt. Range (the basin of Chuya River). We failed to find it there in both tundras and Larix (with Hylocomium + Rhytidium) forests, though on the north-facing slope of that range, in Bashkaus River Basin, it was found as a very rare species.
Specimens examined: Bogoyash Creek, upper course $2200 \mathrm{~m}$ (36/165); Bolshoye Istyube Creek 470 m (0/2089a); Booshkon Creek, upper course $1900 \mathrm{~m}$ (Zolotukhin \& al. 31.VII.1979); Chiri Creek, 0.5 km upstream $450 \mathrm{~m}$ (17/21a); Kairu-Bazhi Peak 2050 m (13/109); Karatumysh 2000 m (Zolotukhin \& al. 30.VII.1978); Kayakkatuyarykskij Creek 1920 m (3/161a); Kobiguayuk Creek 2220 m (0/360), 2300 m (0/652), 2908 m (0/976); Kolyushta Peak $2030 \mathrm{~m}$ (Zolotukhin \& al. 27.VII.1982); Malaya Kokorya Creek 2300 m (36/168); Seminskij Pass 2000 m (173; Velikanov \& al. 27.VIII.1961); Tamanel Peak $1800 \mathrm{~m}$ (34/186); Turochak Creek, at mouth $970 \mathrm{~m}$ (Zolotukhin \& al. 5.VI.1986); Uedinennoye Lake $880 \mathrm{~m}(0 / 977)$.

\section{AKNOWLEDGEMENTS}

We are very grateful to Dr. N. I. Zolotukhin and L. V. Bardunov for making to our disposal their collection from Altai and adjacent regions and also to curators of H, FH, G, LE, NY, and S for loan of specimes, including type collections important for this study. Also we thank Dr. W. R. Buck for the revision of English and other advises on the manuscript. 


\section{LITERATURE CITED}

[ABRAMOVA, A. L. \& I. I. ABRAMOV] АБРАMOBA А. Л., И. И. АБРАМОВ 1981. Об эндемичных листостебельных мхах СССР. 1. Cephalocladium zerovii Lazar. - [On the endemic mosses of the USSR. 1. Cephalocladium zerovii Lazar.] Новости сист. низи. раст. [Novosti Sist. Nizsh. Rast.] 18: 179-187.

AFONINA, O. M. \& I. V. CZERNYADJEVA 1995. Mosses of the Russian Arctic: ckeck-list and bibliography. Arctoa 5: 99-142.

ANDO, H. 1964. A revision of East-Asian species of Homomallium, a genus of Musci. I. - Hikobia 4: 28-42.

ANDO, H. 1965. A revision of East-Asian species of Homomallium, a genus of Musci. II. - Hikobia 4: 161-177.

ANDO, H. 1966. A revision of the Chinese Cupressinae described by C. Müller. - Bot. Mag., Tokyo 79: 759-769.

ANDO, H. 1973. Studies on the genus Hypnum Hedw. II. J. Sci. Hiroshima Univ., Ser. B, Div. 2, 14: 165-207.

ANDO, H. 1977[1976] Studies on the genus Hypnum Hedw. III. - J. Sci. Hiroshima Univ., Ser. B, Div. 2, 16(1): 1-46.

ANDO, H. 1989. Studies on the genus Hypnum Hedw. VI.

- Hikobia 10: 269-291.

ANDO, H. 1990. Studies on the genus Hypnum Hedw. VII. - Hikobia 10: 409-417.

ANDO, H. 1992. Studies on the genus Hypnum Hedw. VIII. - Hikobia 11: 111-123.

ANDO, H. 1993. Studies on the genus Hypnum Hedw. IX. - Hikobia 11: 265-275.

ANDO, H. 1994. A revision of Hypnum aemulans Limpr., with record of a new species, H. holmenii (Sect. Hamulosa) from northern North America, Greenland and Finland. - Hikobia 11: 363-370.

ANDO, H. 1996. Studies on the genus Hypnum Hedw. X. Hikobia 12: 9-17.

ANDO, H. \& M. HIGUCHI 1984. Caribaeohypnum, a new genus for a northern Latin American moss, Hypnum polypterum (Mitt.) Broth. - Cryptogamie, Bryol., Lichenol. 5: 7-14.

[BARDUNOV, L. V.] БАРДУНОВ, Л. В. 1974. Листостебельные мхи Алтая и Саян - [Mosses of the Altai and Sayan Mts.]. Новосибирск, Наука [Novosibirsk, Nauka], 168.

BROTHERUS, V. F. 1925. Musci. II. - In: Engler, A. \& K. Prantl, Die natuerlichen Pflanzenfamilien, $2 d$ ed., $W$. Engelmann, Leipzig 11: 1-542.

BUCK, W. R. 1980. A generic revision of the Entodontaceae. - J. Hattori Bot. Lab. 48: 71-159.

BUCK, W. R. \& H. CRUM 1978. Entodon schleicheri new to North America. - Bryologist 81(3): 429-432.

BUCK, W. R. \& R. R. IRELAND 1985. A reclassification of the Plagiotheciaceae. - Nova Hedwigia 41: 89-125.

CORLEY, M. V. F., A. C. CRUNDWELL, R. DÜLL, M. O. HILL \& A. J. E. SMITH 1981. Mosses of Europe and the Azores: an annotated list of species, with synonyms from the recent literature. - J. Bryol. 11(4): 609-689.

CRUM, H. 1971. Nomenclatural changes in the Musci. Bryologist 74: 165-174.
CRUM, H. \& L. E. ANDERSON 1981. Mosses of the Eastern North America. I-II. New-York, Columbia Univ. Press, 1328.

CRUNDWELL, A. C. 1979. Rhizoids and moss taxonomy. - In: Clarke, G. C. S \& J. G. Ducket (eds.), Bryophyte Systematics, Academic Press, New-York: 347-363.

DEMETER, C. 1884. Entodon transsylvanicus spec. nov. Hedwigia 6: 81-84.

DE NOTARIS, G. 1867. Cronaca della briologia italiana. Comment. Soc. Crittag. Ital. (Genova) 2: 269-312.

DÜLL, R. 1985. Distribution of the European and Macaronesian mosses (Bryophytina). 1. - Bryol. Beitr. 4: 1-109.

ENROTH, J. 1994. A taxonomic revision of the genus Pinnatella (Neckeraceae, Bryopsida). - Acta Bot. Fennica 151: $1-90$.

FLEISCHER, M. 1912. Laubmoose. - Nova Guinea 8 (Bot., 2): 735-753, pls. CXIX-CXXIV.

FLEISCHER, M. 1914. Laubmoose. - Nova Guinea 12 (Bot., 2): 109-128, pls. XXIX-XXXIV.

FLEISCHER, M. 1923. Bryales: Hypnobryales, Buxbaumiales, Diphysciales, Polytrichales. - In: Die Musci der Flora von Buitenzorg. Bd. 4. E. J. Brill, Leidin: 11051729, pls. I-XXXI.

HEDENÄS, L. 1987. North European mosses with axillary rhizoids, a taxonomic study. - J. Bryol. 14: 429-439.

HEDENÄS, L. 1989. Some neglected character distribution patterns among the pleurocarpous mosses. - Bryologist 92(2): 157-163.

HEDENÄS, L. 1992[1990]. Taxonomic and nomenclatural notes on the genera Calliergonella and Breidleria. Lindbergia 16: 161-168.

HEDENÄS, L. 1995. Higher taxonomic level relationships among diplolepidous pleurocarpous mosses - a cladistic overvew. - J. Bryol. 18: 723-781.

HIGUCHI, M. 1985. A taxonomic revision of the genus Gollania Broth. (Musci). - J. Hattori Bot. Lab. 59: 1-77.

HIGUCHI, M. 1991. Gollania (Hypnaceae, Musci) in the Himalayas. - Hikobia 11: 57-61.

HIGUCHI, M. \& D. G. LONG 1996. A collection of Hypnaceous mosses from the Eastern Himalaya and Yunnan. - Bull. Natn. Sci. Mus., Tokyo. Ser. B, 22: 11-18.

HIGUCHI, M. \& P. WU 1995. A note on the genus Gollania (Musci) from southwesten China, with a description of a new species, G. homalothecioides. - J. Jap. Bot. 70: 239-242.

HU, R. 1983. A revision of the Chinese species of Entodon (Musci, Entodontaceae). - Bryologist 86(3): 193-233.

IGNATOV, M. S. 1990. New recored of mosses from the northwestern Altai Mountains. - Acta Bryolichenologica Asiatica 2(1-2): 17-24.

IGNATOV, M. S. 1992. The relationships of moss flora of Altai Mts. - Bryobrothera 1: 63-72.

IGNATOV, M. S. 1994. Bryophytes of Altai Mountains. I. Study area and history of its bryological exploration. Arctoa 3: 13-27.

IGNATOV, M. S. \& R. OCHYRA 1995. On the systematic 
position of Myurella and Bardunovia, genus novum (Plagiotheciaceae, Musci). - Arctoa 5: 45-59.

INOUE, S. 1971. Karyological studies on mosses, VII. Karyotypes of fourteen species in Sematophyllaceae, Hypnaceae and Hylocomiaceae. - Bot. Mag., Tokyo 84: 247-255.

INOUE, S. \& Z. IWATSUKI 1987. Cytotaxonomic studies of Plagiothecium B.S.G. and its related genera. - J. Hattori Bot. Lab. 63: 453-471.

IRELAND, R. R.1986. Synopsis of the genus Taxi phyllum for North america. - Lindbergia 12: 153-157.

IWATSUKI, Z. 1970. A revision of Plagiothecium and its related genera from Japan and her adjacent areas. I. J. Hattori Bot. Lab. 33: 331-380.

IWATSUKI, Z. 1987. Notes on Isopterygium Mitt. (Plagiotheciaceae). - J. Hattori Bot. Lab. 63: 445-451.

IWATSUKI, Z. \& J. M. GLIME 1984. Podperaea, a new genus of Hypnaceae (Musci). - J. Hattori Bot. Lab. 55: 495-500.

IWATSUKI, Z. \& W. B. SCHOFIELD 1973. The taxonomic position of Campylium adscendens (Lindb.) Mitt. J. Hattori Bot. Lab. 37: 609-615.

KOPONEN, T. 1971. Rhytidiadelphus japonicus and R. subpinnatus. - Hikobia 6(1-2): 18-35.

[KRYLOV, Р.] КРЫЛОВ, П. 1925. Материалы к флоре споровых растений Алтая и Томской губернии. [Contributions to the flora of spore plants of Altai and Tomsk Province]. Изв. Томск. Гос. Ун-та [Izv. Tотsk. Gos. Univ.] 75: 1-48.

[LAZARENKO, A. S.] ЛАЗАРЕНКО А. С. 1946. Бріологічні нотатки - [Bryological notes]. Бот. журн. АН УРСР [Bot. Zhurn. Akad. Nuuk UkrRSR](1946)(3-4): 61-63.

LIMPRICHT, K. G. 1895-1904. Die Laubmoose Deutschlands, Osterreichs und der Schweiz. III Abt. Leipzig.

MIZUSHIMA, U. 1960. Japanese Entodontaceae. - J. Hat- tori Bot. Lab. 22: 91-158.

MUELLER, D. M. J. \& A. J. NEUMANN 1988. Peristome structure and the regulation of spore release in arthrodontous mosses. - Advances Bryol. 3: 135-158.

NISHIMURA, N, M. HIGUCHI, T. SEKI \& H. ANDO 1984. Delimitation and subdivision of the moss family Hypnaceae. - J. Hattori Bot. Lab. 55: 227-234.

NYHOLM, E. 1965. Illustrated Moss flora of Fennoscandia. II. Musci. Fasc. 5. Gleerups, Lund: 407-647.

OCHYRA, R. \& P. SZMAJDA 1990. Atlas of the geographical distribution of spore plants in Poland. Ser. 5, Mosses. Pt.5. Krakow-Poznan, W.Szafer Inst. Bot. \& Adam Mickiewicz Univ.

REDFEARN, P. L., JR., B. C. TAN \& S. HE 1996. A newly updated and annotated checklist of Chinese mosses. J. Hattori Bot. Lab. 79: 163-357.

ROHRER, J. R. 1985a. A phenetic and phylogenetic analysis of the Hylocomiaceae and Rhytidiaceae. - J. Hat tori Bot. Lab. 59: 185-240.

ROHRER, J. R. 1985b. A generic revision of the Hylocomiaceae. - J. Hattori Bot. Lab. 59: 241-278.

SCHOFIELD, W. B. 1992. Hypnum plicatulum (Lindb.) Jaeg. in eastern North America. - Contr. Univ. Michigan Herb. 18: 87-90.

SÖDERSTRÖM, L., K. KARTTUNEN \& L. HEDENAES 1992. Nomenclatural notes on Fennoscandian bryophytes. - Ann. Bot. Fennici 29: 119-122.

TAN, B. C. \& W. R. BUCK 1989. A synoptic review of Philippine Sematophyllaceae with emphasis on Clastobryoideae and Heterophylloideae (Musci). - J. Hattori Bot. Lab. 66: 307-320.

TAN, B. C., W. R. BUCK \& M. S. IGNATOV 1990. On the Himalayan Struckia C. Müll. and Russian Cephalocaldium Lazar. (Musci, Hypnaceae). - Lindbergia 16(3): 100-104. 